\title{
Dietary protein to support active aging
}

Citation for published version (APA):

Holwerda, A. M. (2019). Dietary protein to support active aging. [Doctoral Thesis, Maastricht University]. Maastricht University. https://doi.org/10.26481/dis.20190321ah

Document status and date:

Published: 01/01/2019

DOI:

10.26481/dis.20190321ah

Document Version:

Publisher's PDF, also known as Version of record

\section{Please check the document version of this publication:}

- A submitted manuscript is the version of the article upon submission and before peer-review. There can be important differences between the submitted version and the official published version of record.

People interested in the research are advised to contact the author for the final version of the publication, or visit the DOI to the publisher's website.

- The final author version and the galley proof are versions of the publication after peer review.

- The final published version features the final layout of the paper including the volume, issue and page numbers.

Link to publication

\footnotetext{
General rights rights.

- You may freely distribute the URL identifying the publication in the public portal. please follow below link for the End User Agreement:

www.umlib.nl/taverne-license

Take down policy

If you believe that this document breaches copyright please contact us at:

repository@maastrichtuniversity.nl

providing details and we will investigate your claim.
}

Copyright and moral rights for the publications made accessible in the public portal are retained by the authors and/or other copyright owners and it is a condition of accessing publications that users recognise and abide by the legal requirements associated with these

- Users may download and print one copy of any publication from the public portal for the purpose of private study or research.

- You may not further distribute the material or use it for any profit-making activity or commercial gain

If the publication is distributed under the terms of Article $25 \mathrm{fa}$ of the Dutch Copyright Act, indicated by the "Taverne" license above, 


\section{DIETARYPROTEIN TO SUPPORT ACTIVE AGING Andrew M. Holwerda}


Propositions related to the dissertation entitled

\section{Dietary protein to support active aging}

1. A minimum of $30 \mathrm{~g}$ protein should be ingested by older individuals to increase post-exercise skeletal muscle protein synthesis rates. (This thesis)

2. Dietary protein ingestion prior to sleep represents a practical and efficient strategy to increase protein intake in the older population. (This thesis)

3. Consuming food in an upright body position is preferred to optimize the postprandial rise in muscle protein synthesis rate. (This thesis)

4. Incorporating regular anabolic factors, such as habitual physical activity and diet, into the assessment of muscle protein synthesis rates will provide more insight into the impact of intervention strategies designed to preserve muscle mass. (This thesis)

5. Encouraging strategies to maximize the impact of smaller protein doses should be preferred over simply encouraging ingestion of greater protein doses.

6. The main determinant of sarcopenia appears to be the decline in resistance-type physical activities. (Millward, Am J Clin Nutr 1997)

7. We do not stop exercising because we grow old - we grow old because we stop exercising. (Dr. Kenneth Cooper)

8. We have surely attained enough knowledge in rodents to make them the healthiest species on the planet.

9. An expert is one who has made all the mistakes which can be made, in a narrow field. (Niels Bohr) 
Dietary protein to support active aging 


\section{NUTRIM}

The studies presented in this thesis were performed within the NUTRIM, School of Nutrition and Translational Research in Metabolism at Maastricht University. Studies presented in this thesis were performed within the framework of TI Food and Nutrition.

Cover design: Yvette Krist

Layout: Andrew Holwerda

Printed by: Gildeprint

ISBN: 978-90-829801-3-4

(C) Copyright Andrew Holwerda, Maastricht 2019

All rights reserved. No part of this thesis may be reproduced, distributed, or transmitted in any form or by any means, including photocopying, recording, or other electronic or mechanical methods, without the prior written permission of the author or publisher, except in the case of brief quotations embodied in critical reviews and certain other noncommercial uses permitted by copyright law. 


\title{
Dietary protein to support active aging
}

\author{
DISSERTATION
}

To obtain the degree of Doctor at Maastricht University, on the authority of the Rector Magnificus, Prof. dr. Rianne M. Letschert in accordance with the decision of the Board of Deans, to be defended in public on Thursday, March 21, 2019, at 12:00 PM

By

Andrew M. Holwerda

Born May 12, 1987, Hamilton, Canada 


\section{Promotor}

Prof. dr. L.J.C. van Loon

\section{Co-promotor}

Dr. L.B. Verdijk

\section{Assessment Committee}

Prof. dr. E.C.M. Mariman (Chair)

Prof. dr. J.G. Burniston (Liverpool John Moores University, United Kingdom)

Prof. dr. S.W.M. Olde Damink

Prof. dr. O. Rooyackers (Karolinska Institute, Sweden)

Prof. dr. W.H.M. Saris 


\section{Table of Contents}

Chapter 1

Chapter 2

Chapter 3

Chapter 4

Chapter 5

Chapter 6

Chapter 7

Chapter 8

Chapter 9

Summary

Valorization

Acknowledgements

Daily resistance-type exercise stimulates muscle protein synthesis in vivo in young men

Protein supplementation after exercise and before sleep does not further augment muscle mass and strength gains during resistance exercise training in active older men

General discussion

Balance and Dietary Protein-Derived Amino Acid Incorporation into Myofibrillar Protein During Recovery from Resistance Exercise in Older Men

Leucine co-ingestion augments the muscle protein synthetic response to the ingestion of $15 \mathrm{~g}$ protein following resistance exercise in older men

Physical activity performed in the evening increases the protein ingestion in older men

Body position modulates gastric emptying and affects the post-prandial rise in plasma amino acid concentrations following protein ingestion in humans

Food ingestion in an upright sitting position increases post-prandial amino acid availability when compared to food ingestion in a lying down position

Curriculum Vitae

Financial Support 



\section{Chapter 1}

General introduction 


\section{Aging Demographics}

One of our generation's forthcoming challenges is the rapid expansion of the population aged 60 years and older (3). Current World Health Organization estimations predict that the worldwide population over 60 years old will triple within the upcoming 40 years, reaching approximately 2 billion by 2050 (129). In economically developed countries such as Canada and the Netherlands, the representation of individuals older than 65 years of age will increase from $15 \%$ to approximately $27 \%$ within the next 40 years $(29,103,104)$. Remarkably, developed countries are also on pace to triple the population of their oldest old, defined as those over 85 years of age, by $2050(29,103)$. Whereas the dramatic expansion of the older population represents meaningful progress of technological advancement and healthcare policies, unique socioeconomic challenges will emerge in the near future.

\section{Sarcopenia}

One challenge presented by the rapid growth of our aging population will be an increased dependence upon clinical support systems. Older individuals in good health are more likely to remain independent and sustain a physically and socially active lifestyle. In particular, maintaining good health throughout the lifespan prevents or delays the onset of chronic metabolic diseases, such as obesity, heart disease, and diabetes. One important factor that enables a healthy and active lifestyle is an individual's functional capacity, which is strongly associated with skeletal muscle mass and strength.

In healthy adults, skeletal muscle tissue comprises approximately $40 \%$ of total body mass (54). However, starting from the $4^{\text {th }}$ decade of life, skeletal muscle mass declines at a rate of 0.5-1.0 \% per year $(38,44,95)$. This age-related decline in skeletal muscle mass has been termed sarcopenia $(30,60,125)$ and occurs in $30 \%$ of individuals over 60 years of age and in more than $50 \%$ of individuals over 80 years of age (73). The seemingly low rate of muscle loss accumulates to a staggering amount over an entire lifespan. For example, a $75 \mathrm{~kg}$ individual would be expected to lose as much as $15 \mathrm{~kg}$ of skeletal muscle mass between the ages of 30 and 80 years of age $(112,113)$. The age-related loss of skeletal muscle mass is also characterized by unfavorable changes in muscle fiber morphology. In particular, aging is associated with a decrease in type II muscle fiber cross sectional area $(58,68,76)$ and fibertype grouping $(58,67,68)$.

The age-related loss of skeletal muscle mass and disturbances at the muscle fiber level are accompanied by a concomitant and persistent loss in muscle strength $(38,39)$. The rate of strength loss is several fold greater when compared with the rate of skeletal muscle mass loss, with reports demonstrating that strength declines by approximately $5 \%$ each year (73). The more rapid decline in strength when compared to skeletal muscle mass indicates that other factors, such as a decline in neuromuscular function, contribute to the age-related loss 
of muscle strength $(28,64)$. Importantly, muscle strength is a central determinant of functional capacity (32). When functional capacity is dramatically reduced, individuals often struggle to maintain an independent lifestyle. Altogether, the loss of independence in older individuals combined with the rapid expansion of the older population will place a greater dependence on existing healthcare systems. As such, effective intervention strategies are required to prevent or slow the progression of skeletal muscle mass and strength loss in order to reduce the prevalence of sarcopenia.
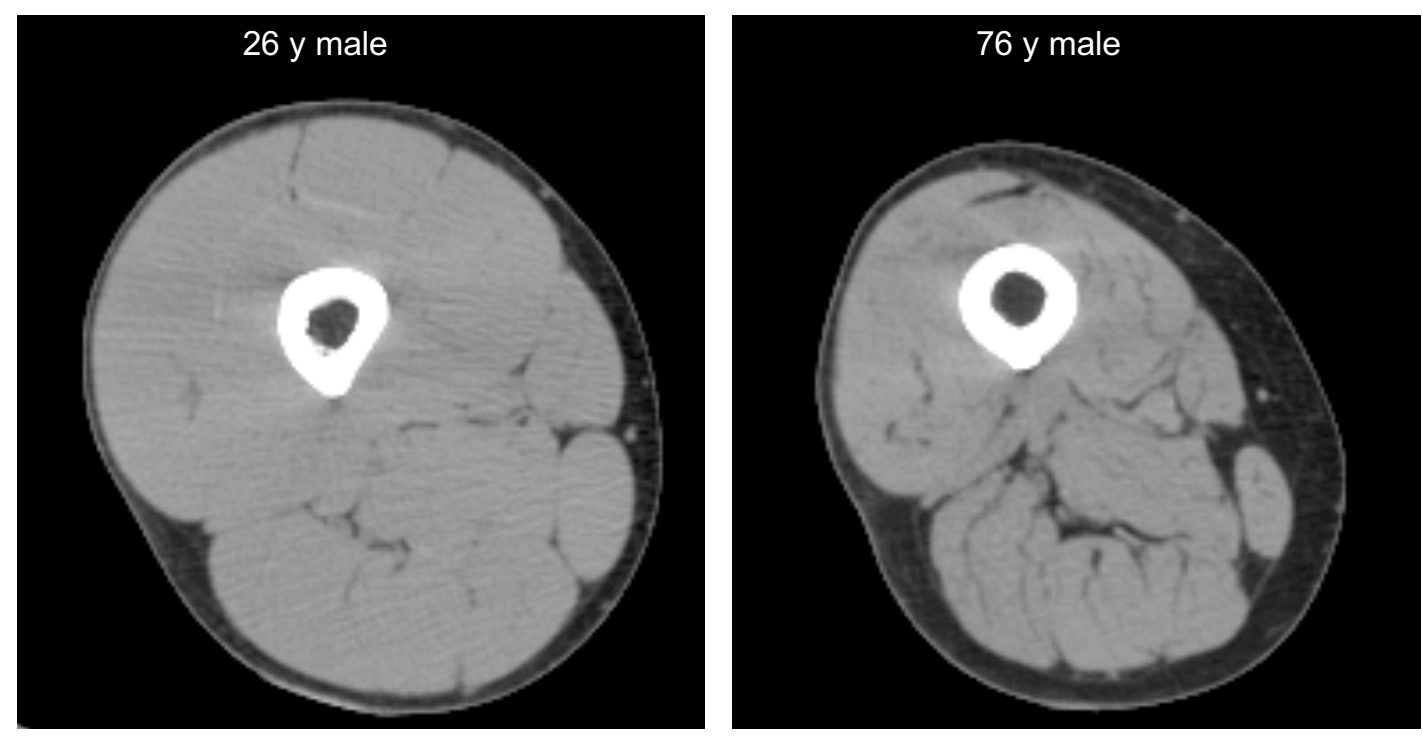

Figure 1.1 Computed tomography (CT) scan of the upper leg (mid-thigh level) in young and old male subjects. The old subject displays reduced muscle area, increased subcutaneous fat, and increased fat and connective tissue infiltration into the muscle.

\section{Skeletal muscle mass regulation}

Aside from providing an obvious locomotive role, skeletal muscle tissue is a principal contributor to whole-body metabolism. In particular, skeletal muscle accounts for approximately $30 \%$ of resting energy expenditure and is the largest site of post-prandial glucose disposal and its storage as glycogen $(83,105,134)$. Skeletal muscle tissue also represents the largest reservoir for amino acid storage in the human body. In fasted conditions, amino acids are released from skeletal muscle protein to preserve whole-body glucose homeostasis (85) and also serve as precursors to support remodeling of other tissues. Within skeletal muscle tissue, free amino acids are continuously synthesized into protein and broken down again. This process, termed skeletal muscle protein turnover, occurs at an average rate of 1-2 \% per day. As such, skeletal muscle proteins are completely broken-down and re-synthesized every 3 months on average. The balance between muscle protein synthesis and breakdown rates facilitates tissue remodeling, including changes in skeletal muscle mass over time. For example, a sustained positive net muscle protein 
balance, whereby muscle protein synthesis rates exceed muscle protein breakdown rates, results in skeletal muscle hypertrophy. On the other hand, a sustained negative protein balance will result in skeletal muscle atrophy. Muscle protein synthesis and breakdown rates are impacted by many factors, including diet, physical activity, and aging.

\section{Methodological approaches to assess muscle protein turnover}

Muscle protein synthesis rates can be assessed in vivo in humans by the application of stable isotope methodology $(89,121)$. Labeled amino acids contain one or more heavy stable isotopes (i.e., ${ }^{13} \mathrm{C},{ }^{2} \mathrm{H}$ ) in place of their lighter counterparts (i.e., ${ }^{12} \mathrm{C},{ }^{1} \mathrm{H}$ ). Following administration of labeled amino acids (i.e., L-[1- $\left.{ }^{13} \mathrm{C}\right]$-leucine or $\mathrm{L}-\left[\right.$ ring $\left.-{ }^{13} \mathrm{C}_{6}\right]$-phenylalanine) to human subjects, the relative abundance of labeled versus unlabeled amino acids in plasma and/or tissue samples can be assessed using mass spectrometry techniques. By combining a continuous intravenous infusion of labeled amino acids with repeated sampling of blood and muscle tissue, the incorporation rate of labeled amino acids into skeletal muscle protein can be determined. This approach has been commonly applied to assess the impact of various factors, such as dietary protein ingestion, exercise, muscle disuse and disease, on fractional muscle protein synthesis rates (Table 1.1).

The application of labeled amino acid methodologies over the last few decades has greatly expanded our understanding of the regulation of muscle protein metabolism and the impact of food ingestion on muscle protein synthesis rates. Much of the earlier work aiming to understand the regulation of the post-prandial rise in muscle protein synthesis rates have applied study designs in which test participants ingested free (essential) amino acids $(8,87$, $110,117-119)$. This work has established the basis of our understanding of the anabolic properties of (essential) amino acids $(110,118)$, and leucine in particular (100), on skeletal muscle tissue. However, the ingestion of free (essential) amino acids as opposed to intact protein results in a greater and more rapid release of dietary-derived amino acids into the circulation (12). The more rapid release of amino acids following free (essential) amino acid ingestion may provide a more potent anabolic stimulus for skeletal muscle tissue when compared to the ingestion of intact dietary protein (77). Furthermore, free (essential) amino acid ingestion is not part of a normal dietary pattern. As such, considerable work is presently being conducted to investigate the muscle protein synthetic response to the ingestion of intact dietary proteins in isolation or together with other meal components that are typically contained in whole foods $(15,80,81,114)$. For instance, recent work has demonstrated that the ingestion of mixed meals, where protein is co-ingested with carbohydrates, fats, and/or other nutrients, may also impact the post-prandial skeletal muscle protein synthetic response $(46,47,99)$. To extend our understanding of post-prandial protein handling, it is therefore necessary to apply methodologies that are able to assess protein digestion and dietary protein-derived amino acid absorption into the circulation and the subsequent impact on muscle protein synthesis rates. 
Early work by Boirie et al. described the production of so-called intrinsically-labeled protein, which was applied to directly assess the post-prandial appearance rate of dietary proteinderived amino acids from the gut into the circulation (10). The production of intrinsicallylabeled milk protein involves continuous intravenous infusion of labeled amino acids into lactating dairy cows. Subsequent collection of milk and purification of the labeled milk protein fractions (i.e., milk protein concentrate, or whey and casein) provides dietary protein for subsequent use in clinical experiments in vivo in humans. One of the first applications of intrinsically-labeled proteins in vivo in humans investigated post-prandial protein digestion and amino acid absorption rates to establish the concept of slow and fast proteins (9). Since then, the production of intrinsically-labeled protein has been modified by substantially increasing labeled amino acid enrichments. A greater labeled amino acid enrichment in labeled protein allows for the direct assessment of protein-derived amino acid utilization for de novo skeletal muscle protein synthesis $(80,82,88)$. Current applications of intrinsicallylabeled protein provide the capability to perform in vivo assessment of post-prandial protein handling, which consists of dietary protein digestion and amino acid absorption into the circulation, splanchnic extraction of dietary-protein derived amino acids and/or the utilization of dietary protein-derived amino acids for de novo muscle protein synthesis (12, $15,24,26,45,46,69,80,82,88,114)$. Together, these data provide better insight into the metabolic fate of dietary protein-derived amino acids (Table 1.1).

Labeled amino acid infusion methodologies provide sufficient sensitivity to detect subtle changes in muscle protein synthesis rates, such as during the post-prandial period after dietary protein ingestion. However, labeled amino acid infusion studies are restricted to an assessment period of approximately 12 hours due to labeled amino acid "recycling" between free amino acid and protein pools $(97,111)$. This methodological limitation has restricted our understanding of how muscle protein synthesis is regulated over longer periods, such as several days-to-weeks. Recently, a stable-isotope methodology based upon deuterated water $\left({ }^{2} \mathrm{H}_{2} \mathrm{O}\right)$ ingestion has re-emerged in the field, which can be applied to assess muscle protein synthesis rates for several days or even weeks $(42,96)$. Ingestion of deuterated water enriches the body water pool with deuterium, allowing for endogenous deuterium labeling of the non-essential amino acid, alanine. The deuterium-labeled alanine is synthesized into muscle proteins, which can be detected in muscle tissue protein that has been isolated from muscle biopsy samples and used to calculate muscle protein synthesis rates $(93,96,127)$. The endogenous labeling of alanine and slow elimination rate of deuterium oxide from the body water pool allows amino acid labeling to remain in near steady-state conditions over experimental protocols that last for days to weeks $(93,96,127)$. As such, application of the deuterated water method allows for the assessment of muscle protein synthesis rates without the need for primed, continuous intravenous infusion protocols (Table 1.1). 


\section{Chapter 1}

Table 1.1 A comparison of the different tracer methodologies applied in the present thesis to assess muscle protein synthesis rates under a variety of conditions in vivo in human participants.

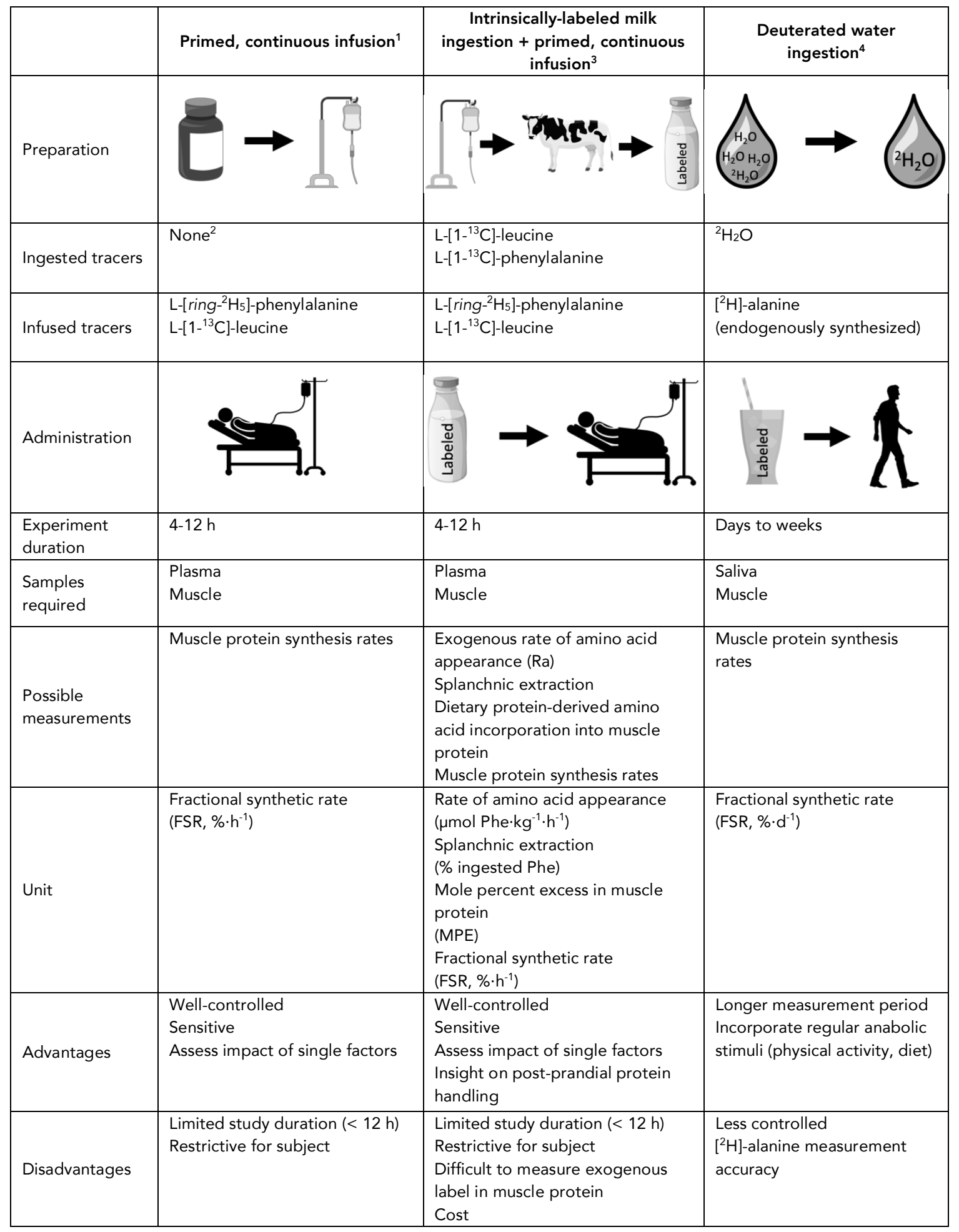

${ }^{1}$ Infusate for primed, continuous infusion is prepared by dissolving powdered labeled amino acid tracers in saline solution. Intravenous infusion in human participants combined with plasma and muscle biopsy sampling allows for the measurement of tracer incorporation in skeletal muscle protein and subsequent calculation of a fractional synthetic rate over a 4-12 $h$ period $\left(F S R, \% \cdot h^{-1}\right) .{ }^{2}$ Free crystalline amino acid tracer matching the infused tracer can 
be co-ingested with dietary amino acids and/or protein to maintain tracer steady-state during the experimental period.

${ }^{3}$ Intrinsically labeled proteins are prepared by infusing large amounts of an amino acid tracer (i.e., L-[1- $\left.{ }^{13} \mathrm{C}\right]-$ phenylalanine) into lactating dairy cows and collecting the milk. Milk is processed into a protein isolate and prepared for human consumption. Intrinsically labeled milk is ingested during an intravenous infusion of amino acid tracers. Plasma and muscle biopsy samples are collected and analyzed for the orally and intravenously administered tracers to determine rate of dietary protein-derived amino acid appearance into the circulation ( $\mu$ mol Phe $\cdot \mathrm{kg}^{-1} \cdot \mathrm{h}^{-1}$ ), splanchnic extraction (percent of ingested phenylalanine), dietary protein-derived amino acid incorporation into muscle protein (Mole percent excess, MPE) and calculation of muscle protein fractional synthetic rate $\left(F S R, \% \cdot h^{-1}\right)$.

${ }^{4}$ Deuterated water $\left({ }^{2} \mathrm{H}_{2} \mathrm{O}\right)$ is concentrated from regular water by repeated distillation. Deuterated water is ingested by test participants, which increases circulating $\left[{ }^{2} \mathrm{H}\right]$-alanine enrichment. Subjects are not restricted to a laboratory setting and can perform regular daily activities during the experiment. Saliva and muscle samples are collected and used to calculate a fractional synthetic rate $\left(F S R, \% \cdot d^{-1}\right)$ over multiple days or weeks.

\section{Impact of dietary protein intake and exercise on muscle protein turnover}

Dietary protein ingestion represents one of the main anabolic stimuli for skeletal muscle tissue. Following food ingestion, dietary protein is digested and absorbed resulting in a rapid rise in circulating amino acid concentrations. The rise in circulating amino acid concentrations is accompanied by the release of insulin, which increases blood flow to peripheral tissues and ultimately enhances nutrient delivery to skeletal muscle tissue $(41,108,116)$. Once delivered to the periphery, amino acids are actively transported across the sarcolemma into the intramyocellular space. In the post-prandial phase, intramyocellular essential amino acids, and leucine in particular, nearly double in concentration (6). The increase in intracellular leucine concentration stimulates intracellular anabolic signaling activity (i.e., mTORC1, p70S6K), which triggers a cascade of molecular events that eventually lead to an increase in the rate of muscle protein synthesis $(1,56,61)$. The abundance of intracellular dietary protein-derived amino acids also serves as a pool of precursors that can be utilized to support the increase in post-prandial muscle protein synthesis rates. Overall, it is evident that the muscle protein synthetic response to food ingestion is regulated by several factors, which include: the rate of protein digestion and amino acid absorption $(59,81)$, post-prandial insulin release $(41,48,49)$, skeletal muscle tissue perfusion $(86,133)$, amino acid delivery to skeletal muscle tissue $(108,109)$, amino acid transport into the muscle fiber (27), the intracellular anabolic signaling response $(25,40)$, ribosomal biogenesis $(36,37)$, and myofibrillar protein synthesis (117).

Exercise is the most potent anabolic stimulus for skeletal muscle tissue. A single bout of resistance-type exercise increases mixed and myofibrillar protein synthesis rates by $40-150$ $\%(7,21,84)$. The robust increase in muscle protein synthesis rates during post-exercise recovery is accompanied by an increase in muscle protein breakdown rates $(7,21,84)$. Whereas the simultaneous increase in muscle protein synthesis and muscle protein breakdown rates following exercise improve net muscle protein balance, net balance will remain negative in the absence of food ingestion $(7,8,84)$. 
Protein ingestion during post-exercise recovery induces a greater $(82,128)$ and more prolonged increase in muscle protein synthesis rates (74) when compared to protein ingestion in rested conditions (Figure 1.2). Furthermore, protein ingestion attenuates postexercise muscle protein breakdown rates $(7,8)$. Together, the increase in muscle protein synthesis rates and attenuation in muscle protein breakdown rates result in a positive net muscle protein balance during post-exercise recovery (87).

Resistance-type exercise sensitizes skeletal muscle tissue towards the anabolic properties of dietary protein ingestion $(74,82)$. The post-exercise increase in sensitivity towards the ingestion of dietary protein persists for at least 24 hours following a bout of resistance-type exercise (16). It is therefore evident that meal ingestion during the 24 hour post-exercise recovery period is utilized to allow a positive net muscle protein balance and promote skeletal muscle reconditioning over time.

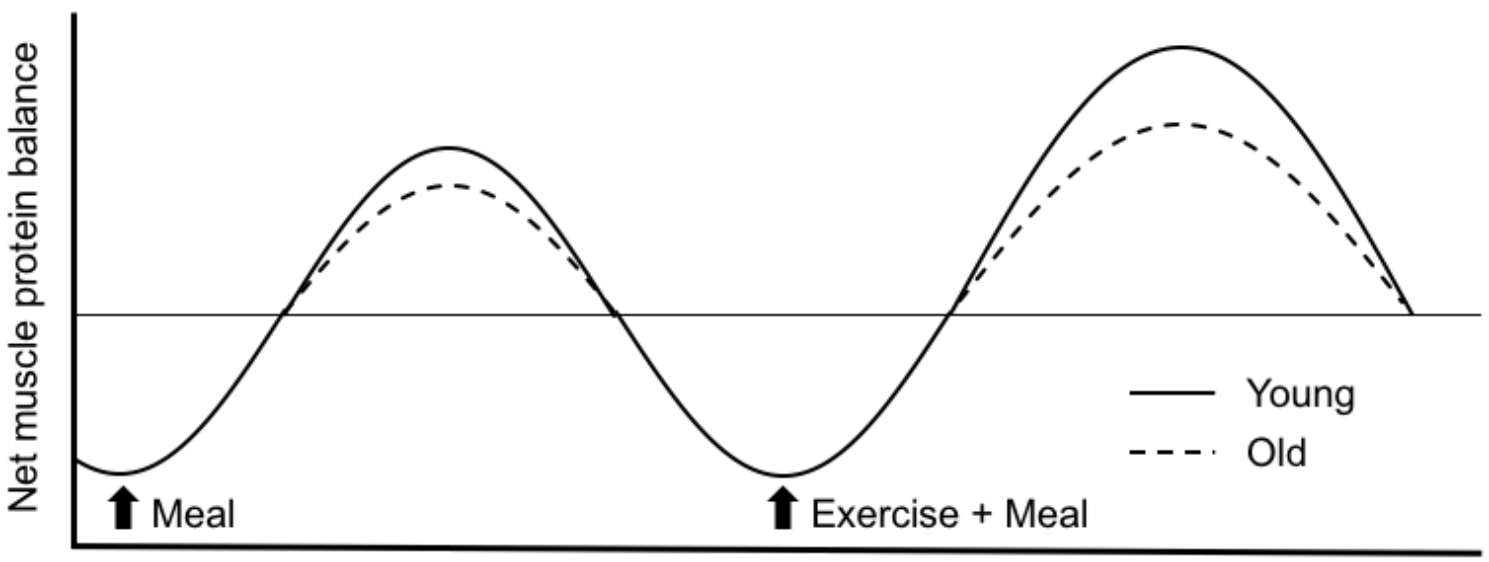

Time

Figure 1.2 Fluctuations in net muscle protein balance (NPB = muscle protein synthesis - muscle protein breakdown) after ingestion of a protein-containing meal in the rested state and during post-exercise recovery in young and old individuals. The solid line represents the response in young individuals and the dotted line represents the response in older individuals. Meal ingestion increases net muscle protein balance. In comparison, meal ingestion during post exercise recovery further increases net muscle protein balance. Anabolic resistance to dietary protein ingestion in older individuals has been observed in the rested state and during post-exercise recovery.

Several long-term intervention studies have demonstrated that protein supplementation further increases skeletal muscle mass and strength gains following resistance-type exercise training $(51,57,107,122)$. In contrast, a number of other studies have not demonstrated any significant surplus benefits of protein supplementation on the training-induced increases in skeletal muscle mass and strength $(5,17,18,43,52,53,63,66,71,115)$. Despite these discrepancies, recent meta-analyses have confirmed that protein supplementation augments the skeletal muscle adaptive response to prolonged resistance-type exercise training (19, 75). As such, the combination of resistance-type exercise training and protein 
supplementation represents one of the most effective strategies to promote increases in skeletal muscle mass and strength.

\section{Anabolic resistance with aging}

The loss of skeletal muscle mass over the lifespan is, at least partly, caused by a disruption in skeletal muscle protein turnover, resulting in a negative net muscle protein balance. Over the last few decades, researchers have attempted to better understand age-related skeletal muscle mass loss by assessing potential differences in muscle protein turnover rates between younger and older individuals. It was initially reported that older individuals display lower basal muscle protein synthesis rates when compared with younger individuals $(2,98,132)$. More recently, however, no detectable age-related differences in basal muscle protein synthesis rates have been observed $(56,78,120)$. This has led research groups to investigate possible disturbances in the sensitivity of skeletal muscle tissue to the main anabolic stimuli (i.e., food intake and physical activity). It has now been well established that the muscle protein synthetic response to dietary protein ingestion is generally blunted in older individuals when compared with younger individuals $(25,55,123)$. This blunted muscle protein synthetic response to food ingestion, termed anabolic resistance, is currently thought to represent one of the key factors responsible for the age-related decline in skeletal muscle mass. Presently, many research groups are investigating physiological and/or molecular disturbances responsible for the development of anabolic resistance. It has been demonstrated that older individuals may display changes in dietary protein digestion and amino acid absorption rate (11), circulating hormone concentrations (33), muscle capillarization $(79,101)$, muscle amino acid transporter content and activity (27), muscle anabolic signaling protein content and activity $(25,40)$, and ribosomal biogenesis (13). These contributing factors are depicted in Figure 1.3. 


\section{Protein Meal}

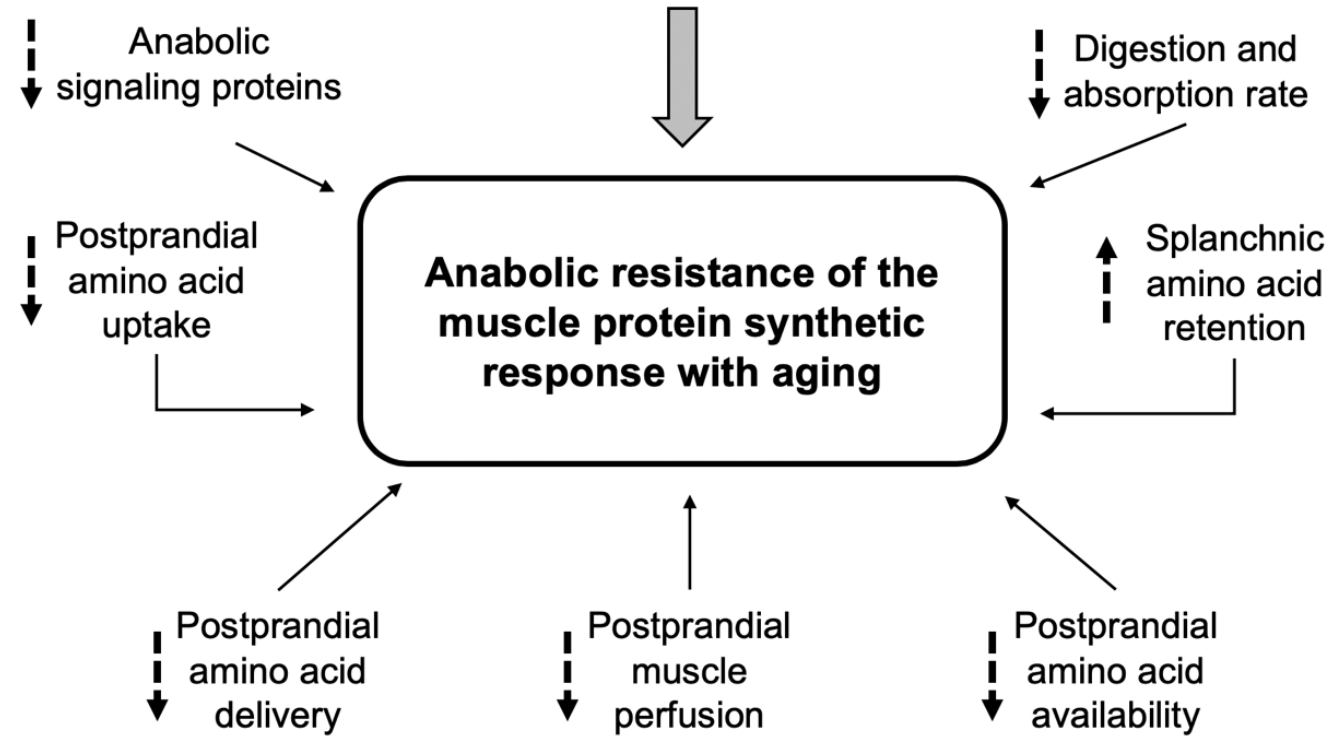

Figure 1.3 Protein intake increases muscle protein synthesis rates. Post-prandial protein synthesis is regulated on various levels. These supportive processes may become impaired with aging and can contribute to a blunted anabolic response to protein ingestion. Adapted from Burd et al. (14).

Strategies to combat sarcopenia

Sarcopenia can be counteracted by compensating for the presence of anabolic resistance. Protein ingestion is one of the main anabolic stimuli for skeletal muscle tissue and therefore represents a suitable strategy that can be applied to further increase muscle protein synthesis rates. In fact, various factors related to protein ingestion have been shown to impact the post-prandial rise in muscle protein synthesis rates following protein ingestion. In particular, it is currently known that the amount $(80,92,130)$, the amino acid composition $(22,56,124)$ and the rate of digestion and amino acid absorption $(9,72,126)$ of the ingested protein modulate post-prandial muscle protein synthesis rates (Figure 1.4). However, while these modulating factors have been well-established to impact post-prandial muscle protein synthesis rates in young individuals, the application of these concepts in older individuals remain to be thoroughly defined. In addition, there are several factors external to the nutrient properties of dietary protein that have been shown to impact the rise in muscle protein synthesis rates following protein ingestion. For example, different food preparation methods (minced beef vs beef steak and cooked vs raw foods) $(31,81)$ and an individual's efficiency at chewing food (91) have been shown to modulate the rate of protein digestion and amino acid absorption as well as the subsequent stimulation of muscle protein synthesis rates. Based on these early findings, further exploration into the impact of various nondietary factors that can modulate dietary protein digestion and amino acid absorption is warranted. Besides modulating the muscle protein synthetic response to ingestion of the 
main meals (i.e., breakfast, lunch and dinner), nutritional strategies should aim to increase muscle protein synthesis rates during prolonged post-absorptive periods throughout the day. It has been demonstrated that amino acid availability and muscle protein synthesis rates are lowest during overnight sleep (4). Recently, the concept of protein ingestion prior to sleep has been introduced as a strategy to increase circulating dietary protein-derived amino acids and stimulate an increase in muscle protein synthesis rates during overnight sleep (50, 90). While pre-sleep protein ingestion is regarded as a promising strategy to compensate for anabolic resistance, the efficacy for pre-sleep protein ingestion to stimulate skeletal muscle mass accretion in the older population remains to be established.

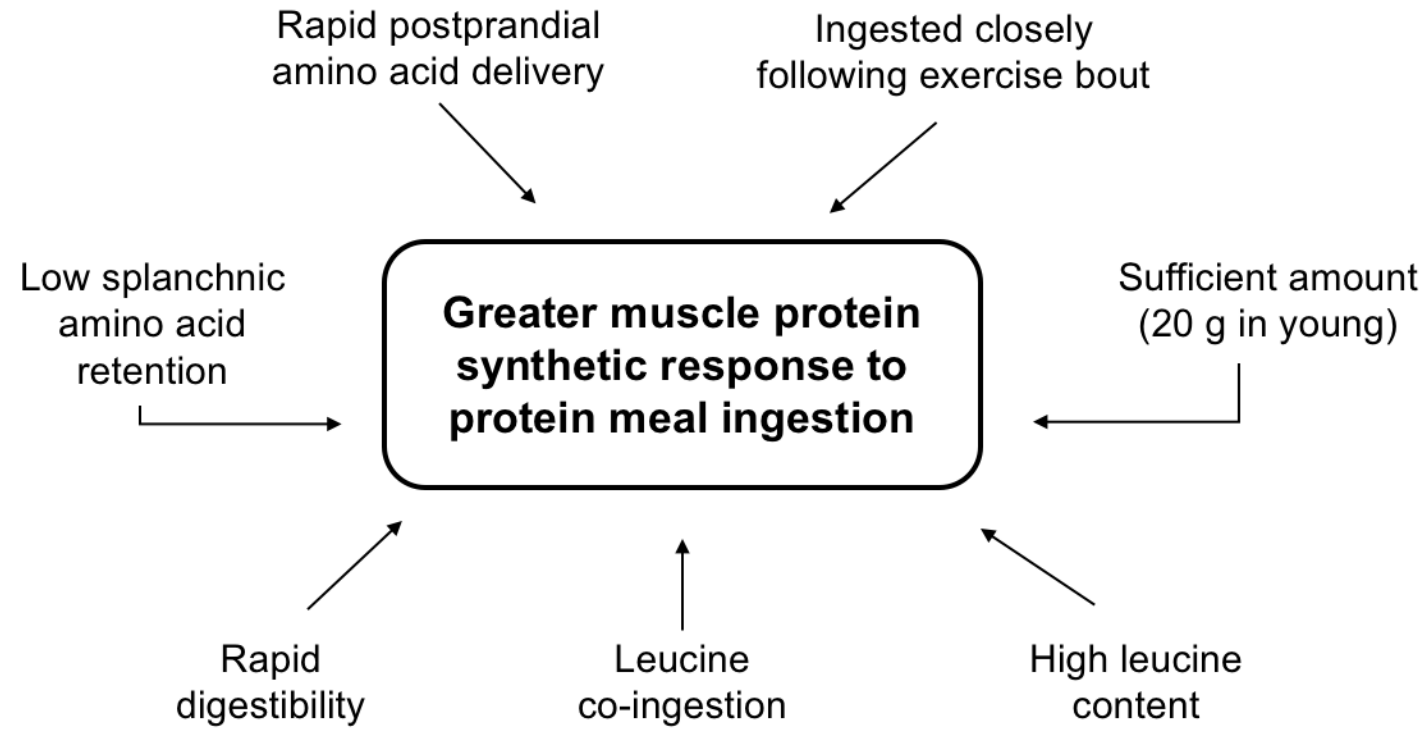

Figure 1.4 Protein intake during post exercise recovery stimulates a greater net muscle protein balance through a robust stimulation in muscle protein synthesis rates. However, many factors of the ingested protein can modulate the muscle protein synthetic response during post exercise recovery.

Physical activity represents the most potent anabolic stimulus for skeletal muscle tissue (7, $21,84)$. It is well known that prolonged resistance-type exercise training increases muscle mass and strength. While the skeletal muscle adaptive response to resistance-type exercise training was initially described in healthy, young individuals $(94,106)$, more recent work has described the impact of resistance-type exercise training to increase skeletal muscle mass and strength in a variety of more compromised populations $(20,70,102)$. More specifically, various studies have demonstrated that an 12-24 week structured resistance-type exercise program can lead to a $1-2 \mathrm{~kg}$ gain in whole body lean mass and a substantial increase in muscle strength in the older population $(65,107,115)$. Remarkably, heavy resistance-type exercise training has also been demonstrated to effectively increase muscle mass and strength in women over the age of 90 years $(34,35)$. These findings indicate that the anabolic properties of resistance-type exercise training on skeletal muscle mass and strength are not restricted by an individual's age. It is therefore evident that the application of resistance- 
type exercise represents one of the most effective strategies to combat age related muscle loss in a variety of older populations.

The synergistic impact of resistance-type exercise and dietary protein ingestion to increase muscle protein accretion has been well established $(19,75)$. Therefore, it is obvious that some combination of resistance-type exercise and protein ingestion should be applied in older individuals to preserve skeletal muscle mass and strength. At this point, however, nutritional strategies specifically targeted to overcome the presence of anabolic resistance in the older population have not been completely defined. It is becoming clearer that the amount and amino acid composition of ingested protein are important factors that can modulate post-prandial muscle protein synthesis rates in older individuals $(92,124,130,131)$. However, the amount and amino acid composition of ingested protein that is required to maximize acute post-exercise muscle protein synthesis rates specifically in the older population remains to be determined (23). Furthermore, while pre-sleep protein ingestion appears to increase overnight muscle protein synthesis rates $(50,62,90)$, more work is needed to determine the efficacy for pre-sleep protein ingestion to increase daily muscle protein synthesis rates and augment muscle mass gains in the older population. Lastly, incorporation of many of these factors into dietary intervention studies is required to evaluate their impact the skeletal muscle adaptive response to resistance-type exercise training in the older population. 


\section{Outline of the dissertation}

This dissertation outlines a number of studies that investigate nutritional and physical activity intervention strategies to augment skeletal muscle mass and strength in healthy older individuals. In Chapter 2, we combine intrinsically-labeled milk and contemporary labeled amino acid tracer infusion methodology to assess the amount of protein required to maximize post-prandial muscle protein synthesis rates during post-exercise recovery in older individuals. Using this approach, we assess the availability of dietary protein-derived amino acids in the circulation, the muscle protein synthetic response during recovery from a single bout of exercise, and the incorporation of dietary protein-derived amino acids in skeletal muscle protein. As leucine has strong anabolic signaling properties, we assess in Chapter 3 whether co-ingestion of a small amount of free crystalline leucine with a small dose of dietary protein further increases the muscle protein synthetic response during post exercise recovery and directs more dietary protein-derived amino acids towards de novo muscle protein synthesis in older men. We have recently observed that protein ingestion prior to sleep increases overnight muscle protein synthesis rates, which may serve as a nutritional strategy to prevent muscle mass decline in older individuals. In Chapter 4, we assessed whether physical activity performed in the evening further increases the overnight muscle protein synthetic response to pre-sleep protein ingestion in older men. We also question whether post-prandial body position would impact gastric emptying, protein digestion, and subsequent post-prandial plasma amino acid availability (Chapter 5 ). We follow up on this work in Chapter 6, where we assess how a supine body position, simulating a sleeping position, impacts gastric emptying and dietary protein-derived amino acid availability following protein ingestion. A large gap exists in our understanding of the day-to-day regulation of muscle protein synthesis rates in response to physical activity and food intake. Therefore, in Chapter 7, we apply a novel deuterated water method to assess the impact of a short, daily bout of resistance-type exercise on daily muscle protein synthesis rates assessed over 3 days in vivo in healthy, young men. We combine concepts and methodologies from the preceding studies in Chapter 8 to assess the impact of leucineenriched protein supplementation immediately after exercise and prior to sleep on skeletal muscle mass and strength gains during 12 weeks of whole-body resistance-type exercise training in healthy older men. In this study, we also apply the deuterated water method to assess myofibrillar protein synthesis rates in response to protein supplementation during the latter stages of the training intervention. Finally, in Chapter 9, we discuss whether postexercise muscle protein synthetic responses can be used to predict gains in skeletal muscle mass during more prolonged resistance-type exercise training. Furthermore, we evaluate the relevance of the deuterated water method in future research as a means to assess the impact of various nutrition, exercise and/or pharmaceutical interventions to modulate muscle protein synthesis rates over a more prolonged timeline of several days to up to a couple of weeks. 


\section{References}

1. Anthony JC, Yoshizawa F, Anthony TG, Vary TC, Jefferson LS, Kimball SR. Leucine stimulates translation initiation in skeletal muscle of postabsorptive rats via a rapamycin-sensitive pathway. $J$ Nutr 130: 2413-2419, 2000.

2. Balagopal P, Rooyackers OE, Adey DB, Ades PA, Nair KS. Effects of aging on in vivo synthesis of skeletal muscle myosin heavy-chain and sarcoplasmic protein in humans. Am J Physiol 273: E790-800, 1997.

3. Beard JR, Officer A, de Carvalho IA, Sadana R, Pot AM, Michel J-P, Lloyd-Sherlock P, Epping-Jordan JE, Peeters GMEEG, Mahanani WR, Thiyagarajan JA, Chatterji S. The World report on ageing and health: a policy framework for healthy ageing. Lancet 387: 2145-2154, 2016.

4. Beelen M, Tieland M, Gijsen AP, Vandereyt H, Kies AK, Kuipers H, Saris WHM, Koopman R, van Loon LJC. Coingestion of Carbohydrate and Protein Hydrolysate Stimulates Muscle Protein Synthesis during Exercise in Young Men, with No Further Increase during Subsequent Overnight Recovery. J Nutr 138: 2198-2204, 2008.

5. Bemben MG, Witten MS, Carter JM, Eliot KA, Knehans AW, Bemben DA. The effects of supplementation with creatine and protein on muscle strength following a traditional resistance training program in middle-aged and older men. J Nutr Health Aging 14: 155-159, 2010.

6. Bergström J, Fürst P, Vinnars E. Effect of a test meal, without and with protein, on muscle and plasma free amino acids. Clin Sci 79: 331-337, 1990.

7. Biolo G, Maggi SP, Williams BD, Tipton KD, Wolfe RR. Increased rates of muscle protein turnover and amino acid transport after resistance exercise in humans. Am J Physiol 268: E514-20, 1995.

8. Biolo G, Tipton KD, Klein S, Wolfe RR. An abundant supply of amino acids enhances the metabolic effect of exercise on muscle protein. Am J Physiol Endocrinol Metab 273: E122-E129, 1997.

9. Boirie $Y$, Dangin M, Gachon P, Vasson MP, Maubois JL, Beaufrere B. Slow and fast dietary proteins differently modulate postprandial protein accretion. Proc Natl Acad Sci USA 94: 14930-14935, 1997.

10. Boirie Y, Fauquant J, Rulquin H, Maubois JL, Beaufrere B. Production of large amounts of [13C]leucine-enriched milk proteins by lactating cows. J Nutr 125: 92-98, 1995.

11. Boirie $\mathbf{Y}$, Gachon P, Beaufrere B. Splanchnic and whole-body leucine kinetics in young and elderly men. Am J Clin Nutr 65: 489-495, 1997.

12. Boirie $\mathbf{Y}$, Gachon P, Corny S, Fauquant J, Maubois JL, Beaufrere B. Acute postprandial changes in leucine metabolism as assessed with an intrinsically labeled milk protein. Am J Physiol 271: E1083-91, 1996.

13. Brook MS, Wilkinson DJ, Mitchell WK, Lund JN, Phillips BE, Szewczyk NJ, Greenhaff PL, Smith K, Atherton PJ. Synchronous deficits in cumulative muscle protein synthesis and ribosomal biogenesis underlie age-related anabolic resistance to exercise in humans. J Physiol 594: 7399-7417, 2016.

14. Burd NA, Gorissen SH, van Loon LJC. Anabolic resistance of muscle protein synthesis with aging. Exerc Sport Sci Rev 41: 169-173, 2013.

15. Burd NA, Gorissen SH, van Vliet S, Snijders T, van Loon LJ. Differences in postprandial protein handling after beef compared with milk ingestion during postexercise recovery: a randomized controlled trial. Am J Clin Nutr 102: 828-836, 2015.

16. Burd NA, West DWD, Moore DR, Atherton PJ, Staples AW, Prior T, Tang JE, Rennie MJ, Baker SK, Phillips SM. Enhanced amino acid sensitivity of myofibrillar protein synthesis persists for up to $24 \mathrm{~h}$ after resistance exercise in young men. J Nutr 141: 568-573, 2011.

17. Campbell WW, Crim MC, Young VR, Joseph LJ, Evans WJ. Effects of resistance training and dietary protein intake on protein metabolism in older adults. Am J Physiol 268: E1143-53, 1995.

18. Candow DG, Chilibeck PD, Facci M, Abeysekara S, Zello GA. Protein supplementation before and after resistance training in older men. Eur J Appl Physiol 97: 548-556, 2006.

19. Cermak NM, Res PT, de Groot LCPGM, Saris WHM, van Loon LJC. Protein supplementation augments the adaptive response of skeletal muscle to resistance-type exercise training: a meta-analysis. Am J Clin Nutr 96: 1454-1464, 2012.

20. Charette SL, McEvoy L, Pyka G, Snow-Harter C, Guido D, Wiswell RA, Marcus R. Muscle hypertrophy response to resistance training in older women. J Appl Physiol 70: 1912-1916, 1991.

21. Chesley A, MacDougall JD, Tarnopolsky MA, Atkinson SA, Smith K. Changes in human muscle protein synthesis after resistance exercise. J Appl Physiol 73: 1383-1388, 1992. 

Breuille D, Offord EA, Baker SK, Phillips SM. Leucine supplementation of a low-protein mixed macronutrient beverage enhances myofibrillar protein synthesis in young men: a double-blind, randomized trial. Am J Clin Nutr 99: 276-286, 2014.

23. Churchward-Venne TA, Holwerda AM, Phillips SM, van Loon LJC. What is the Optimal Amount of Protein to Support Post-Exercise Skeletal Muscle Reconditioning in the Older Adult? Sports Med 46: 1205-1212, 2016.

24. Churchward-Venne TA, Snijders T, Linkens AMA, Hamer HM, van Kranenburg J, van Loon LJC Ingestion of Casein in a Milk Matrix Modulates Dietary Protein Digestion and Absorption Kinetics but Does Not Modulate Postprandial Muscle Protein Synthesis in Older Men. J Nutr 145: 1438-1445, 2015. Cuthbertson D, Smith K, Babraj J, Leese G, Waddell T, Atherton P, Wackerhage H, Taylor PM, Rennie MJ. Anabolic signaling deficits underlie amino acid resistance of wasting, aging muscle. FASEB J 19: 422-424, 2005.

26. Dangin $\mathbf{M}$, Boirie $\mathbf{Y}$, Guillet $\mathbf{C}$, Beaufrère $\mathbf{B}$. Influence of the protein digestion rate on protein turnover in young and elderly subjects. J Nutr 132: 3228S-33S, 2002.

27. Dickinson JM, Drummond MJ, Coben JR, Volpi E, Rasmussen BB. Aging differentially affects human skeletal muscle amino acid transporter expression when essential amino acids are ingested after exercise. Clin Nutr 32: 273-280, 2013.

28. Doherty TJ, Vandervoort AA, Taylor AW, Brown WF. Effects of motor unit losses on strength in older men and women. J Appl Physiol 74: 868-874, 1993.

29. Eurostat. Population structure and ageing [Online]. http://ec.europa.eu/eurostat/statisticsexplained/index.php/Population_structure_and_ageing\#Past_and_future_population_ageing_trends_i n_the_EU.

30. Evans WJ. Skeletal muscle loss: cachexia, sarcopenia, and inactivity. Am J Clin Nutr 91: 1123S-1127S, 2010.

31. Evenepoel P, Geypens B, Luypaerts A, Hiele M, Ghoos Y, Rutgeerts P. Digestibility of cooked and raw egg protein in humans as assessed by stable isotope techniques. J Nutr 128: 1716-1722, 1998.

32. Faulkner JA, Larkin LM, Claflin DR, Brooks SV. Age-related changes in the structure and function of skeletal muscles. Clin Exp Pharmacol Physiol 34: 1091-1096, 2007.

33. Feldman HA, Longcope C, Derby CA, Johannes CB, Araujo AB, Coviello AD, Bremner WJ, McKinlay JB. Age trends in the level of serum testosterone and other hormones in middle-aged men: longitudinal results from the Massachusetts male aging study. J Clin Endocrinol Metab 87: 589-598, 2002.

34. Fiatarone MA, Marks EC, Ryan ND, Meredith CN, Lipsitz LA, Evans WJ. High-intensity strength training in nonagenarians. Effects on skeletal muscle. JAMA 263: 3029-3034, 1990.

Fiatarone MA, O'Neill EF, Ryan ND, Clements KM, Solares GR, Nelson ME, Roberts SB, Kehayias JJ, Lipsitz LA, Evans WJ. Exercise training and nutritional supplementation for physical frailty in very elderly people. N Engl J Med 330: 1769-1775, 1994.

36. Figueiredo VC, Caldow MK, Massie V, Markworth JF, Cameron-Smith D, Blazevich AJ. Ribosome biogenesis adaptation in resistance training-induced human skeletal muscle hypertrophy. Am J Physiol Endocrinol Metab 309: E72-E83, 2015.

37. Figueiredo VC, Roberts LA, Markworth JF, Barnett MPG, Coombes JS, Raastad T, Peake JM, Cameron-Smith D. Impact of resistance exercise on ribosome biogenesis is acutely regulated by postexercise recovery strategies. Physiol Rep 4: e12670-12, 2016.

38. Frontera WR, Hughes VA, Fielding RA, Fiatarone MA, Evans WJ, Roubenoff R. Aging of skeletal muscle: a 12-yr longitudinal study. J Appl Physiol 88: 1321-1326, 2000.

39. Frontera WR, Hughes VA, Lutz KJ, Evans WJ. A cross-sectional study of muscle strength and mass in 45- to 78-yr-old men and women. J Appl Physiol 71: 644-650, 1991.

40. Fry CS, Drummond MJ, Glynn EL, Dickinson JM, Gundermann DM, Timmerman KL, Walker DK, Dhanani S, Volpi E, Rasmussen BB. Aging impairs contraction-induced human skeletal muscle mTORC1 signaling and protein synthesis. Skelet Muscle 1: 11, 2011.

41. Fujita S, Rasmussen BB, Cadenas JG, Grady JJ, Volpi E. Effect of insulin on human skeletal muscle protein synthesis is modulated by insulin-induced changes in muscle blood flow and amino acid availability. Am J Physiol Endocrinol Metab 291: E745-54, 2006.

42. Gasier HG, Fluckey JD, Previs SF. The application of $2 \mathrm{H} 2 \mathrm{O}$ to measure skeletal muscle protein synthesis. Nutr Metab 7: 31-8, 2010. 
43. Godard MP, Williamson DL, Trappe SW. Oral amino-acid provision does not affect muscle strength or size gains in older men. Med Sci Sports Exerc 34: 1126-1131, 2002.

44. Goodpaster BH, Park SW, Harris TB, Kritchevsky SB, Nevitt M, Schwartz AV, Simonsick EM, Tylavsky FA, Visser M, Newman AB, for the Health ABC Study. The Loss of Skeletal Muscle Strength, Mass, and Quality in Older Adults: The Health, Aging and Body Composition Study. J Gerontol A Biol Sci Med Sci 61: 1059-1064, 2006.

45. Gorissen SH, Horstman AM, Franssen R, Kouw IW, Wall BT, Burd NA, de Groot LC, van Loon LJ. Habituation to low or high protein intake does not modulate basal or postprandial muscle protein synthesis rates: a randomized trial. Am J Clin Nutr 105: 332-342, 2017.

46. Gorissen SHM, Burd NA, Hamer HM, Gijsen AP, Groen BB, van Loon LJC. Carbohydrate coingestion delays dietary protein digestion and absorption but does not modulate postprandial muscle protein accretion. J Clin Endocrinol Metab 99: 2250-2258, 2014.

47. Gorissen SHM, Burd NA, Kramer IF, van Kranenburg J, Gijsen AP, Rooyackers O, van Loon LJC. Coingesting milk fat with micellar casein does not affect postprandial protein handling in healthy older men. Clinical Nutrition 36: 429-437, 2017.

48. Greenhaff PL, Karagounis LG, Peirce N, Simpson EJ, Hazell M, Layfield R, Wackerhage H, Smith K, Atherton P, Selby A, Rennie MJ. Disassociation between the effects of amino acids and insulin on signaling, ubiquitin ligases, and protein turnover in human muscle. Am J Physiol Endocrinol Metab 295: E595-604, 2008.

49. Groen BBL, Horstman AMH, Hamer HM, de Haan M, van Kranenburg J, Bierau J, Poeze M, Wodzig WKWH, Rasmussen BB, van Loon LJC. Increasing Insulin Availability Does Not Augment Postprandial Muscle Protein Synthesis Rates in Healthy Young and Older Men. J Clin Endocrinol Metab 101: 39783988, 2016.

50. Groen BBL, Res PT, Pennings B, Hertle E, Senden JMG, Saris WHM, van Loon LJC. Intragastric protein administration stimulates overnight muscle protein synthesis in elderly men. Am J Physiol Endocrinol Metab 302: E52-60, 2012.

51. Hartman JW, Tang JE, Wilkinson SB, Tarnopolsky MA, Lawrence RL, Fullerton AV, Phillips SM. Consumption of fat-free fluid milk after resistance exercise promotes greater lean mass accretion than does consumption of soy or carbohydrate in young, novice, male weightlifters. Am J Clin Nutr 86: 373381, 2007.

52. Holm L, Olesen JL, Matsumoto K, Doi T, Mizuno M, Alsted TJ, Mackey AL, Schwarz P, Kjaer M. Protein-containing nutrient supplementation following strength training enhances the effect on muscle mass, strength, and bone formation in postmenopausal women. J Appl Physiol 105: 274-281, 2008.

53. Iglay HB, Thyfault JP, Apolzan JW, Campbell WW. Resistance training and dietary protein: effects on glucose tolerance and contents of skeletal muscle insulin signaling proteins in older persons. Am J Clin Nutr 85: 1005-1013, 2007.

54. Janssen I, Heymsfield SB, Wang ZM, Ross R. Skeletal muscle mass and distribution in 468 men and women aged 18-88 yr. J Appl Physiol 89: 81-88, 2000.

55. Katsanos CS, Kobayashi H, Sheffield-Moore M, Aarsland A, Wolfe RR. Aging is associated with diminished accretion of muscle proteins after the ingestion of a small bolus of essential amino acids. Am J Clin Nutr 82: 1065-1073, 2005.

56. Katsanos CS, Kobayashi H, Sheffield-Moore M, Aarsland A, Wolfe RR. A high proportion of leucine is required for optimal stimulation of the rate of muscle protein synthesis by essential amino acids in the elderly. Am J Physiol Endocrinol Metab 291: E381-7, 2006.

57. Kerksick CM, Rasmussen CJ, Lancaster SL, Magu B, Smith P, Melton C, Greenwood M, Almada AL, Earnest CP, Kreider RB. The effects of protein and amino acid supplementation on performance and training adaptations during ten weeks of resistance training. J Strength Cond Res 20: 643-653, 2006.

58. Klitgaard H, Mantoni M, Schiaffino S, Ausoni S, Gorza L, Laurent-Winter C, Schnohr P, Saltin B. Function, morphology and protein expression of ageing skeletal muscle: a cross-sectional study of elderly men with different training backgrounds. Acta Physiol Scand 140: 41-54, 1990.

59. Koopman R, Crombach N, Gijsen AP, Walrand S, Fauquant J, Kies AK, Lemosquet S, Saris WHM, Boirie $\mathbf{Y}$, van Loon LJC. Ingestion of a protein hydrolysate is accompanied by an accelerated in vivo digestion and absorption rate when compared with its intact protein. Am J Clin Nutr 90: 106-115, 2009.

60. Koopman R, van Loon LJC. Aging, exercise, and muscle protein metabolism. J Appl Physiol 106: 20402048, 2009. 
61. Koopman R, Wagenmakers AJM, Manders RJF, Zorenc AHG, Senden JMG, Gorselink M, Keizer HA, van Loon LJC. Combined ingestion of protein and free leucine with carbohydrate increases postexercise muscle protein synthesis in vivo in male subjects. Am J Physiol Endocrinol Metab 288: E645-53, 2005.

62. Kouw IW, Holwerda AM, Trommelen J, Kramer IF, Bastiaanse J, Halson SL, Wodzig WK, Verdijk LB, van Loon LJ. Protein Ingestion before Sleep Increases Overnight Muscle Protein Synthesis Rates in Healthy Older Men: A Randomized Controlled Trial. J Nutr 147: 2252-2261, 2017.

63. Kukuljan S, Nowson CA, Sanders K, Daly RM. Effects of resistance exercise and fortified milk on skeletal muscle mass, muscle size, and functional performance in middle-aged and older men: an 18mo randomized controlled trial. J Appl Physiol 107: 1864-1873, 2009.

64. Kurokawa K, Mimori Y, Tanaka E, Kohriyama T, Nakamura S. Age-related change in peripheral nerve conduction: compound muscle action potential duration and dispersion. Gerontology 45: 168-173, 1999.

65. Leenders M, Verdijk LB, van der Hoeven L, van Kranenburg J, Nilwik R, van Loon LJC. Elderly men and women benefit equally from prolonged resistance-type exercise training. J Gerontol A Biol Sci Med Sci 68: 769-779, 2013.

66. Leenders M, Verdijk LB, van der Hoeven L, van Kranenburg J, Nilwik R, Wodzig WKWH, Senden JMG, Keizer HA, van Loon LJC. Protein supplementation during resistance-type exercise training in the elderly. Med Sci Sports Exerc 45: 542-552, 2013.

67. Lexell J, Taylor CC, Sjöström M. What is the cause of the ageing atrophy? Total number, size and proportion of different fiber types studied in whole vastus lateralis muscle from 15- to 83-year-old men. J Neurol Sci 84: 275-294, 1988.

68. Lexell J, Taylor CC. Variability in muscle fibre areas in whole human quadriceps muscle: effects of increasing age. J Anatomy 174: 239-249, 1991.

69. Liebau F, Wernerman J, van Loon LJ, Rooyackers O. Effect of initiating enteral protein feeding on whole-body protein turnover in critically ill patients. Am J Clin Nutr 101: 549-557, 2015.

70. Macaluso A, De Vito G. Muscle strength, power and adaptations to resistance training in older people. Eur J Appl Physiol 91: 450-472, 2003.

71. Meredith CN, Frontera WR, O'Reilly KP, Evans WJ. Body composition in elderly men: effect of dietary modification during strength training. J Am Geriatr Soc 40: 155-162, 1992.

72. Mitchell WK, Phillips BE, Williams JP, Rankin D, Lund JN, Smith K, Atherton PJ. A dose- rather than delivery profile-dependent mechanism regulates the "muscle-full" effect in response to oral essential amino acid intake in young men. J Nutr 145: 207-214, 2015.

73. Mitchell WK, Williams J, Atherton P, Larvin M, Lund J, Narici M. Sarcopenia, dynapenia, and the impact of advancing age on human skeletal muscle size and strength; a quantitative review. Front Physiol 3: 260, 2012.

74. Moore DR, Tang JE, Burd NA, Rerecich T, Tarnopolsky MA, Phillips SM. Differential stimulation of myofibrillar and sarcoplasmic protein synthesis with protein ingestion at rest and after resistance exercise. J Physiol 587: 897-904, 2009.

75. Morton RW, Murphy KT, McKellar SR, Schoenfeld BJ, Henselmans M, Helms E, Aragon AA, Devries MC, Banfield L, Krieger JW, Phillips SM. A systematic review, meta-analysis and meta-regression of the effect of protein supplementation on resistance training-induced gains in muscle mass and strength in healthy adults. Br J Sports Med 52: 376-384, 2018.

76. Nilwik R, Snijders T, Leenders M, Groen BBL, van Kranenburg J, Verdijk LB, van Loon LJC. The decline in skeletal muscle mass with aging is mainly attributed to a reduction in type II muscle fiber size. Exp Gerontol 48: 492-498, 2013.

77. Paddon-Jones D, Sheffield-Moore M, Katsanos CS, Zhang X-J, Wolfe RR. Differential stimulation of muscle protein synthesis in elderly humans following isocaloric ingestion of amino acids or whey protein. Exp Gerontol 41: 215-219, 2006.

78. Paddon-Jones D, Sheffield-Moore M, Zhang X-J, Volpi E, Wolf SE, Aarsland A, Ferrando AA, Wolfe RR. Amino acid ingestion improves muscle protein synthesis in the young and elderly. Am J Physiol Endocrinol Metab 286: E321-8, 2004.

79. Parízková J, Eiselt E, Sprynarová S, Wachtlová M. Body composition, aerobic capacity, and density of muscle capillaries in young and old men. J Appl Physiol 31: 323-325, 1971. 


\section{Chapter 1}

80. Pennings B, Groen B, de Lange A, Gijsen AP, Zorenc AH, Senden JMG, van Loon LJC. Amino acid absorption and subsequent muscle protein accretion following graded intakes of whey protein in elderly men. Am J Physiol Endocrinol Metab 302: E992-9, 2012.

81. Pennings B, Groen BBL, van Dijk J-W, de Lange A, Kiskini A, Kuklinski M, Senden JMG, van Loon LJC. Minced beef is more rapidly digested and absorbed than beef steak, resulting in greater postprandial protein retention in older men. Am J Clin Nutr 98: 121-128, 2013.

82. Pennings B, Koopman R, Beelen M, Senden JMG, Saris WHM, van Loon LJC. Exercising before protein intake allows for greater use of dietary protein-derived amino acids for de novo muscle protein synthesis in both young and elderly men. Am J Clin Nutr 93: 322-331, 2011.

83. Perseghin G, Price TB, Petersen KF, Roden M, Cline GW, Gerow K, Rothman DL, Shulman GI. Increased glucose transport-phosphorylation and muscle glycogen synthesis after exercise training in insulin-resistant subjects. N Engl J Med 335: 1357-1362, 1996.

84. Phillips SM, Tipton KD, Aarsland A, Wolf SE, Wolfe RR. Mixed muscle protein synthesis and breakdown after resistance exercise in humans. Am J Physiol 273: E99-107, 1997.

85. Pozefsky T, Tancredi RG, Moxley RT, Dupre J, Tobin JD. Effects of brief starvation on muscle amino acid metabolism in nonobese man. J Clin Invest 57: 444-449, 1976.

86. Rasmussen BB, Fujita S, Wolfe RR, Mittendorfer B, Roy M, Rowe VL, Volpi E. Insulin resistance of muscle protein metabolism in aging. FASEB J 20: 768-769, 2006.

87. Rasmussen BB, Tipton KD, Miller SL, Wolf SE, Wolfe RR. An oral essential amino acid-carbohydrate supplement enhances muscle protein anabolism after resistance exercise. J Appl Physiol 88: 386-392, 2000.

88. Reitelseder S, Agergaard J, Doessing S, Helmark IC, Lund P, Kristensen NB, Frystyk J, Flyvbjerg A, Schjerling $\mathbf{P}$, van Hall G, Kjaer M, Holm L. Whey and casein labeled with L-[1-13C]leucine and muscle protein synthesis: effect of resistance exercise and protein ingestion. Am J Physiol Endocrinol Metab 300: E231-42, 2011.

89. Rennie MJ. An introduction to the use of tracers in nutrition and metabolism. Proc Nutr Soc 58: 935944, 1999.

90. Res PT, Groen B, Pennings B, Beelen M, Wallis GA, Gijsen AP, Senden JMG, van Loon LJC. Protein ingestion before sleep improves postexercise overnight recovery. Med Sci Sports Exerc 44: 1560-1569, 2012.

91. Rémond D, Machebeuf M, Yven C, Buffière C, Mioche L, Mosoni L, Patureau Mirand P. Postprandial whole-body protein metabolism after a meat meal is influenced by chewing efficiency in elderly subjects. Am J Clin Nutr 85: 1286-1292, 2007.

92. Robinson MJ, Burd NA, Breen L, Rerecich T, Yang Y, Hector AJ, Baker SK, Phillips SM. Dosedependent responses of myofibrillar protein synthesis with beef ingestion are enhanced with resistance exercise in middle-aged men. Appl Physiol Nutr Metab 38: 120-125, 2013.

93. Robinson MM, Turner SM, Hellerstein MK, Hamilton KL, Miller BF. Long-term synthesis rates of skeletal muscle DNA and protein are higher during aerobic training in older humans than in sedentary young subjects but are not altered by protein supplementation. FASEB J 25: 3240-3249, 2011.

94. Sale DG, MacDougall JD. Isokinetic strength in weight-trainers. Eur J Appl Physiol Occup Physiol 53: 128-132, 1984.

95. Sayers SP. High-speed power training: a novel approach to resistance training in older men and women. A brief review and pilot study. J Strength Cond Res 21: 518-526, 2007.

96. Scalzo RL, Peltonen GL, Binns SE, Shankaran M, Giordano GR, Hartley DA, Klochak AL, Lonac MC, Paris HLR, Szallar SE, Wood LM, Peelor FF, Holmes WE, Hellerstein MK, Bell C, Hamilton KL, Miller BF. Greater muscle protein synthesis and mitochondrial biogenesis in males compared with females during sprint interval training. FASEB J 28: 2705-2714, 2014.

97. Schwenk WF, Tsalikian E, Beaufrere B, Haymond MW. Recycling of an amino acid label with prolonged isotope infusion: implications for kinetic studies. Am J Physiol 248: E482-7, 1985.

98. Short KR. Age and aerobic exercise training effects on whole body and muscle protein metabolism. Am J Physiol Endocrinol Metab 286: 92E-101, 2003.

99. Smith GI, Atherton P, Reeds DN, Mohammed BS, Rankin D, Rennie MJ, Mittendorfer B. Dietary omega-3 fatty acid supplementation increases the rate of muscle protein synthesis in older adults: a randomized controlled trial. Am J Clin Nutr 93: 402-412, 2011. 
100. Smith K, Barua JM, Watt PW, Scrimgeour CM, Rennie MJ. Flooding with L-[1-13C]leucine stimulates human muscle protein incorporation of continuously infused L-[1-13C]valine. Am J Physiol 262: E3726, 1992.

101. Snijders T, Nederveen JP, Joanisse S, Leenders M, Verdijk LB, van Loon LJC, Parise G. Muscle fibre capillarization is a critical factor in muscle fibre hypertrophy during resistance exercise training in older men. J Cachexia Sarcopenia Muscle 8: 267-276, 2016.

102. Spruit MA, Gosselink R, Troosters T, De Paepe K, Decramer M. Resistance versus endurance training in patients with COPD and peripheral muscle weakness. European Respiratory Journal 19: 1072-1078, 2002.

103. Statistics Canada. Population and demography [Online]. Canada Year Book. https://www.statcan.gc.ca/pub/11-402-x/2010000/chap/pop/pop02-eng.htm.

104. Statistics Netherlands. Population [Online]. $\mathrm{http} / / /$ statline.cbs.nl/statweb/publication/?vw $=$ t\&dm $=$ slen\&pa $=37296$ eng \&d1 $=a \& d 2=0,10,20,30,40,5$ $0,60,(\mid-1)$, I\&hd=160114-1555\&la=en\&hdr=g1\&stb=t.

105. Thiebaud D, Jacot E, DeFronzo RA, Maeder E, Jequier E, Felber JP. The effect of graded doses of insulin on total glucose uptake, glucose oxidation, and glucose storage in man. Diabetes 31: 957-963, 1982.

106. Thorstensson A, Hultén B, Döbeln von W, Karlsson J. Effect of strength training on enzyme activities and fibre characteristics in human skeletal muscle. Acta Physiol Scand 96: 392-398, 1976.

107. Tieland M, Dirks ML, van der Zwaluw N, Verdijk LB, van de Rest O, de Groot LCPGM, van Loon LJC. Protein supplementation increases muscle mass gain during prolonged resistance-type exercise training in frail elderly people: a randomized, double-blind, placebo-controlled trial. Journal of the American Medical Directors Association 13: 713-719, 2012.

108. Timmerman KL, Lee JL, Dreyer HC, Dhanani S, Glynn EL, Fry CS, Drummond MJ, Sheffield-Moore M, Rasmussen BB, Volpi E. Insulin Stimulates Human Skeletal Muscle Protein Synthesis via an Indirect Mechanism Involving Endothelial-Dependent Vasodilation and Mammalian Target of Rapamycin Complex 1 Signaling. J Clin Endocrinol Metab 95: 3848-3857, 2010.

109. Timmerman KL, Lee JL, Fujita S, Dhanani S, Dreyer HC, Fry CS, Drummond MJ, Sheffield-Moore M, Rasmussen BB, Volpi E. Pharmacological Vasodilation Improves Insulin-Stimulated Muscle Protein Anabolism but Not Glucose Utilization in Older Adults. Diabetes 59: 2764-2771, 2010.

110. Tipton KD, Ferrando AA, Phillips SM, Doyle D, Wolfe RR. Postexercise net protein synthesis in human muscle from orally administered amino acids. Am J Physiol 276: E628-34, 1999.

111. Tsalikian E, Howard C, Gerich JE, Haymond MW. Increased leucine flux in short-term fasted human subjects: evidence for increased proteolysis. Am J Physiol 247: E323-7, 1984.

112. Tzankoff SP, Norris AH. Effect of muscle mass decrease on age-related BMR changes. J Appl Physiol Respir Environ Exerc Physiol 43: 1001-1006, 1977.

113. van Pelt RE, Dinneno FA, Seals DR, Jones PP. Age-related decline in RMR in physically active men: relation to exercise volume and energy intake. Am J Physiol Endocrinol Metab 281: E633-9, 2001.

114. van Vliet S, Shy EL, Abou Sawan S, Beals JW, West DW, Skinner SK, Ulanov AV, Li Z, Paluska SA, Parsons CM, Moore DR, Burd NA. Consumption of whole eggs promotes greater stimulation of postexercise muscle protein synthesis than consumption of isonitrogenous amounts of egg whites in young men. Am J Clin Nutr 106: 1401-1412, 2017.

115. Verdijk LB, Jonkers RA, Gleeson BG, Beelen M, Meijer K, Savelberg HH, Wodzig WK, Dendale P, van Loon LJ. Protein supplementation before and after exercise does not further augment skeletal muscle hypertrophy after resistance training in elderly men. Am J Clin Nutr 89: 608-616, 2009.

116. Vincent MA, Dawson D, Clark ADH, Lindner JR, Rattigan S, Clark MG, Barrett EJ. Skeletal muscle microvascular recruitment by physiological hyperinsulinemia precedes increases in total blood flow. Diabetes 51: 42-48, 2002.

117. Volpi E, Ferrando AA, Yeckel CW, Tipton KD, Wolfe RR. Exogenous amino acids stimulate net muscle protein synthesis in the elderly. J Clin Invest 101: 2000-2007, 1998.

118. Volpi E, Kobayashi H, Sheffield-Moore M, Mittendorfer B, Wolfe RR. Essential amino acids are primarily responsible for the amino acid stimulation of muscle protein anabolism in healthy elderly adults. Am J Clin Nutr 78: 250-258, 2003.

119. Volpi E, Mittendorfer B, Wolf SE, Wolfe RR. Oral amino acids stimulate muscle protein anabolism in the elderly despite higher first-pass splanchnic extraction. Am J Physiol 277: E513-20, 1999. 
120. Volpi E, Sheffield-Moore M, Rasmussen BB, Wolfe RR. Basal muscle amino acid kinetics and protein synthesis in healthy young and older men. JAMA 286: 1206-1212, 2001.

121. Wagenmakers AJ. Tracers to investigate protein and amino acid metabolism in human subjects. Proc Nutr Soc 58: 987-1000, 1999.

122. Walker TB, Smith J, Herrera M, Lebegue B, Pinchak A, Fischer J. The influence of 8 weeks of wheyprotein and leucine supplementation on physical and cognitive performance. Int J Sport Nutr Exerc Metab 20: 409-417, 2010.

123. Wall BT, Gorissen SH, Pennings B, Koopman R, Groen BBL, Verdijk LB, van Loon LJC. Aging Is Accompanied by a Blunted Muscle Protein Synthetic Response to Protein Ingestion. PLoS ONE 10: e0140903, 2015.

124. Wall BT, Hamer HM, de Lange A, Kiskini A, Groen BBL, Senden JMG, Gijsen AP, Verdijk LB, van Loon LJC. Leucine co-ingestion improves post-prandial muscle protein accretion in elderly men. Clin Nutr 32: 412-419, 2013

125. Walrand S, Guillet C, Salles J, Cano N, Boirie Y. Physiopathological mechanism of sarcopenia. Clin Geriatr Med 27: 365-385, 2011.

126. West DW, Burd NA, Coffey VG, Baker SK, Burke LM, Hawley JA, Moore DR, Stellingwerff T, Phillips SM. Rapid aminoacidemia enhances myofibrillar protein synthesis and anabolic intramuscular signaling responses after resistance exercise. Am J Clin Nutr 94: 795-803, 2011.

127. Wilkinson DJ, Franchi MV, Brook MS, Narici MV, Williams JP, Mitchell WK, Szewczyk NJ, Greenhaff PL, Atherton PJ, Smith K. A validation of the application of D2O stable isotope tracer techniques for monitoring day-to-day changes in muscle protein subfraction synthesis in humans. Am J Physiol Endocrinol Metab 306: E571-E579, 2014.

128. Witard OC, Tieland M, Beelen M, Tipton KD, van Loon LJC, Koopman R. Resistance exercise increases postprandial muscle protein synthesis in humans. Med Sci Sports Exerc 41: 144-154, 2009.

129. World Health Organization. Global Health and Aging.

130. Yang Y, Breen L, Burd NA, Hector AJ, Churchward-Venne TA, Josse AR, Tarnopolsky MA, Phillips SM. Resistance exercise enhances myofibrillar protein synthesis with graded intakes of whey protein in older men. Br J Nutr 108: 1780-1788, 2012.

131. Yang Y, Churchward-Venne TA, Burd NA, Breen L, Tarnopolsky MA, Phillips SM. Myofibrillar protein synthesis following ingestion of soy protein isolate at rest and after resistance exercise in elderly men. Nutr Metab 9: 57, 2012.

132. Yarasheski KE, Zachwieja JJ, Bier DM. Acute effects of resistance exercise on muscle protein synthesis rate in young and elderly men and women. Am J Physiol 265: E210-4, 1993.

133. Zhang $\mathbf{H}$, Dellsperger KC, Zhang $\mathbf{C}$. The link between metabolic abnormalities and endothelial dysfunction in type 2 diabetes: an update. Basic Res Cardiol 107: 237, 2012.

134. Zurlo F, Larson K, Bogardus C, Ravussin E. Skeletal muscle metabolism is a major determinant of resting energy expenditure. J Clin Invest 86: 1423-1427, 1990. 


\section{Chapter 2}

Dose-Dependent Increases in Whole-Body Net Protein Balance and Dietary Protein-Derived Amino Acid Incorporation into Myofibrillar Protein During Recovery from Resistance Exercise in Older Men

Andrew M. Holwerda, Kevin J.M. Paulussen, Maarten Overkamp, Joy P.B. Goessens, Irene Fleur Kramer, Will K.W.H. Wodzig, Lex B. Verdijk and Luc J.C. van Loon 
Chapter 2

\section{Abstract}

Background The age-related decline in skeletal muscle mass is, at least partly, attributed to anabolic resistance to food intake. Resistance exercise sensitizes skeletal muscle tissue to the anabolic properties of amino acids.

Objective The present study assessed protein digestion and amino acid absorption kinetics, whole-body protein balance, and the myofibrillar protein synthetic response to the ingestion of different amounts of protein during recovery from resistance exercise in older men.

Methods Forty-eight healthy older men (age: $66 \pm 1$ y BMI: $25.4 \pm 0.3 \mathrm{~kg} \cdot \mathrm{m}^{-2}$ ) were randomly assigned to ingest $0,15,30$ or $45 \mathrm{~g}$ milk protein concentrate following a single bout of resistance exercise consisting of 4 sets of 10 repetitions of leg press and leg extension and 2 sets of 10 repetitions of lateral pull down and chest press performed at 75-80 \% 1RM. Post-prandial protein digestion and amino acid absorption kinetics, whole-body protein metabolism, and myofibrillar protein synthesis rates were assessed using primed, continuous infusions of L-[ring- $\left.{ }^{2} \mathrm{H}_{5}\right]$-phenylalanine, L-[ring- $\left.{ }^{2} \mathrm{H}_{2}\right]-$ tyrosine and $\mathrm{L}-\left[1-{ }^{13} \mathrm{C}\right]$-leucine combined with the ingestion of intrinsically $\mathrm{L}-[1$ $\left.{ }^{13} \mathrm{C}\right]$-phenylalanine and $\mathrm{L}-\left[1-{ }^{13} \mathrm{C}\right]$-leucine labeled protein.

Results Whole-body net protein balance increased in a dose-dependent manner after ingesting $0,15,30$ and $45 \mathrm{~g}$ protein $(0.015 \pm 0.002,0.108 \pm 0.004,0.162 \pm$ $0.008,0.215 \pm 0.009 \mu \mathrm{mol}$ Phe $\cdot \mathrm{kg}^{-1} \cdot \mathrm{min}^{-1}$, respectively; $\left.P<0.001\right)$. Myofibrillar protein synthesis rates were higher after ingesting $30\left(0.0951 \pm 0.0062 \% \cdot h^{-1}\right.$, $P=0.07)$ and $45 \mathrm{~g}\left(0.0970 \pm 0.0062 \% \cdot h^{-1}, P<0.05\right)$ when compared to $0 \mathrm{~g}$ $\left(0.0746 \pm 0.0051 \% \cdot h^{-1}\right)$. The incorporation of dietary protein-derived amino acids (L-[1-13 C]-phenylalanine) into de novo myofibrillar protein increased in a dose-dependent manner after ingesting 15,30 and $45 \mathrm{~g}$ protein $(0.0171 \pm$ $0.0017,0.0296 \pm 0.0030,0.0397 \pm 0.0026 \mathrm{MPE}$, respectively; $P<0.05)$

Conclusions Dietary protein ingested during recovery from resistance exercise is rapidly digested and absorbed. Whole-body net protein balance and dietary proteinderived amino acid incorporation into myofibrillar protein increase in a dosedependent manner. Ingestion of at least $30 \mathrm{~g}$ protein increases post-exercise myofibrillar protein synthesis rates in older men. 


\section{Introduction}

The age-related decline in skeletal muscle mass and strength, termed sarcopenia, is accompanied by impairments in functional capacity and an increased risk of developing chronic metabolic diseases $(1,20)$. Whereas basal muscle protein synthesis and breakdown rates appear to be unaffected by age $(16,26)$, the muscle protein synthetic response to the main anabolic stimuli, food intake and physical activity, seem to be blunted in older individuals $(7,15,35)$. This anabolic resistance is now considered to be a key factor contributing to the progressive loss of skeletal muscle mass throughout our lifespan.

A single bout of resistance exercise strongly increases muscle protein synthesis rates $(2,22$, $28,29)$ and, as such, represents an effective strategy to counteract anabolic resistance. The post-exercise increase in muscle protein synthesis rates can be further augmented by ingesting protein during the recovery phase $(22,28,38)$. The degree to which protein ingestion stimulates muscle protein synthesis rates depends upon the availability of dietary protein-derived amino acids (27). Therefore, the amount of protein ingested after exercise may largely determine the magnitude of the post-exercise muscle protein synthetic response (6). So far, no study has assessed the impact of the amount of protein ingested on the postprandial availability of dietary protein-derived amino acids in the circulation following resistance exercise.

Previous work has provided evidence of a dose-response relationship between the amount of protein ingested and post-exercise muscle protein synthesis rates in younger athletes (21, 38). In these studies, ingestion of $20 \mathrm{~g}\left(\sim 0.25 \mathrm{~g} \mathrm{~kg}^{-1}\right)$ egg (21) or whey (38) protein was shown to induce maximal post-exercise muscle protein synthesis rates in younger men. In contrast, ingestion of protein doses larger than $20 \mathrm{~g}$ appear to induce further increases in muscle protein synthesis rates in older individuals $(27,32,40)$. Therefore, in the present study we assessed post-prandial protein digestion and amino acid absorption kinetics, whole-body protein metabolism, and the muscle protein synthetic response to the ingestion of three different amounts of protein during recovery from a single bout of resistance exercise in older individuals. We hypothesized that a dose-response relationship exists between the amount of protein ingested and the magnitude of the post-prandial increase in muscle protein synthesis rates during recovery from a single bout of resistance-type exercise in healthy, older men. 


\section{Materials and methods}

\section{Subjects}

A total of 48 healthy, normoglycemic, older men (age range: 55-80 y, mean \pm SEM: $66 \pm 1$ y) were selected to participate in the present study. Subjects' characteristics are presented in Table 2.1. All subjects were living independently and were not participating in any structured resistance exercise training program. In a parallel design, subjects were randomly assigned to ingest either: $0 \mathrm{~g}$ (PLA: $n=12), 15 \mathrm{~g}$ (15G: $n=12), 30 \mathrm{~g}$ (30G: $n=12)$ or $45 \mathrm{~g}(45 \mathrm{G}: n=12)$ intrinsically $\mathrm{L}-\left[1-{ }^{13} \mathrm{C}\right]$-phenylalanine and $\mathrm{L}-\left[1-{ }^{13} \mathrm{C}\right]$-leucine labeled milk protein after completing a single bout of resistance exercise. All subjects were informed of the nature and possible risks of the experimental procedures before their written informed consent was obtained. The trial was conducted between July 2014 and March 2015 at the Maastricht University Medical Centre in Maastricht, the Netherlands. The experiments were performed in a randomized and double-blind manner. The study was approved by the Medical Ethical Committee of the Maastricht University Medical Centre, The Netherlands, and conformed to standards for the use of human subjects in research as outlined in the most recent version of the Helsinki Declaration. The study was registered at Nederlands Trial Registry as NTR4492.

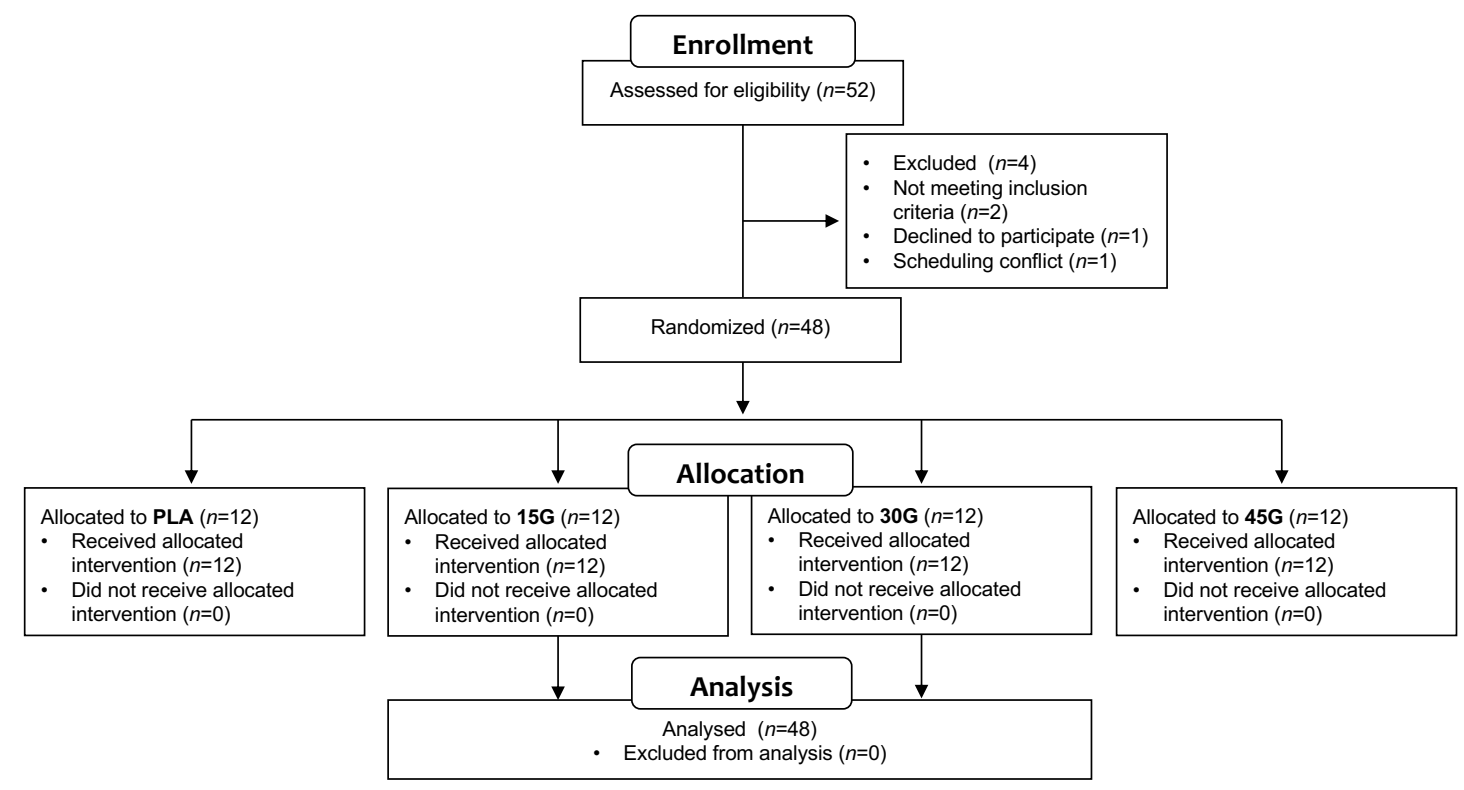

Figure 2.1 CONSORT flowchart for the human tracer infusion trial. CONSORT, Consolidated Standards of Reporting Trials. 
Dose response to post-exercise dietary protein ingestion

Table 2.1 Subjects' characteristics ${ }^{1}$

\begin{tabular}{|c|c|c|c|c|c|c|}
\hline & $\operatorname{PLA}(n=12)$ & $15 \mathrm{G}(n=12)$ & $30 \mathrm{G}(n=12)$ & $45 G(n=12)$ & Total $(n=48)$ & $P$ \\
\hline Age, y & $66 \pm 2$ & $69 \pm 2$ & $66 \pm 1$ & $64 \pm 2$ & $66 \pm 1$ & 0.41 \\
\hline Total Body Mass, kg & $79.0 \pm 3.2$ & $78.8 \pm 3.2$ & $80.6 \pm 1.5$ & $82.7 \pm 2.6$ & $80.3 \pm 1.3$ & 0.73 \\
\hline Total Lean Mass, kg & $58.1 \pm 1.9$ & $57.6 \pm 2.3$ & $61.3 \pm 1.3$ & $61.0 \pm 1.8$ & $59.5 \pm 0.9$ & 0.36 \\
\hline Appendicular Lean Mass, kg & $25.9 \pm 0.9$ & $24.9 \pm 1.1$ & $27.5 \pm 0.7$ & $27.3 \pm 1.0$ & $26.4 \pm 0.5$ & 0.19 \\
\hline Percentage Body Fat, \% & $23.2 \pm 1.1$ & $23.9 \pm 0.9$ & $21.7 \pm 0.9$ & $23.3 \pm 1.1$ & $23.0 \pm 0.5$ & 0.48 \\
\hline Height, m & $1.78 \pm 0.02$ & $1.75 \pm 0.02$ & $1.80 \pm 0.02$ & $1.79 \pm 0.02$ & $1.78 \pm 0.01$ & 0.26 \\
\hline $\mathrm{BMI}, \mathrm{kg} \cdot \mathrm{m}^{-2}$ & $24.9 \pm 0.6$ & $25.8 \pm 0.8$ & $25.0 \pm 0.5$ & $25.9 \pm 0.6$ & $25.4 \pm 0.3$ & 0.62 \\
\hline $\mathrm{HbA} 1 \mathrm{C}, \%$ & $5.5 \pm 0.1$ & $5.3 \pm 0.1$ & $5.4 \pm 0.1$ & $5.4 \pm 0.1$ & $5.4 \pm 0.0$ & 0.49 \\
\hline Resting Plasma Glucose, $\mathrm{mmol} \cdot \mathrm{L}^{-1}$ & $6.0 \pm 0.2$ & $5.8 \pm 0.2$ & $6.0 \pm 0.2$ & $6.1 \pm 0.1$ & $6.0 \pm 0.1$ & 0.71 \\
\hline Resting Plasma Insulin, $\mathrm{mU} \cdot \mathrm{L}^{-1}$ & $7.1 \pm 1.3$ & $9.3 \pm 0.9$ & $7.8 \pm 2.4$ & $7.8 \pm 1.0$ & $8.0 \pm 0.7$ & 0.77 \\
\hline HOMA-IR & $1.9 \pm 0.4$ & $2.4 \pm 0.2$ & $2.2 \pm 0.7$ & $2.1 \pm 0.2$ & $2.1 \pm 0.2$ & 0.90 \\
\hline MVPA, $\min$ & $139 \pm 38$ & $145 \pm 31$ & $174 \pm 42$ & $85 \pm 16$ & $136 \pm 17$ & 0.29 \\
\hline 1RM - Leg Press, kg & $163 \pm 8$ & $179 \pm 8$ & $172 \pm 8$ & $193 \pm 9$ & $177 \pm 4$ & 0.09 \\
\hline 1RM - Leg Extension, kg & $85 \pm 4$ & $86 \pm 6$ & $93 \pm 4$ & $96 \pm 5$ & $90 \pm 2$ & 0.35 \\
\hline 1RM - Lat Pulldown, kg & $63 \pm 2$ & $60 \pm 4$ & $64 \pm 2$ & $68 \pm 2$ & $64 \pm 1$ & 0.28 \\
\hline 1RM - Chest Press, kg & $55 \pm 3$ & $60 \pm 6$ & $66 \pm 4$ & $68 \pm 4$ & $62 \pm 2$ & 0.13 \\
\hline
\end{tabular}

${ }^{1}$ Values are mean \pm SEM. $n=12$ per treatment group. PLA: placebo, 15G: $15 \mathrm{~g}$ dietary protein, $30 \mathrm{G}: 30 \mathrm{~g}$ dietary protein, 45G: $40 \mathrm{~g}$ dietary protein. 1RM: one repetition maximum, $\mathrm{HbA}_{1} \mathrm{C}$ : glycosylated hemoglobin, MVPA: Moderate-vigorous physical activity, Resting: resting and fasted values. Data were analyzed with a one-way ANOVA. No differences were detected between groups.

\section{Pretesting}

Participants arrived at the laboratory at $0830 \mathrm{~h}$ by car or public transport in an overnight fasted state. Upon arrival, body weight, body composition, and bone mineral content were measured with DEXA (Dual-energy X-ray absorptiometry; Discovery A; Hologic, Bedford, MA). Thereafter, all participants performed an oral glucose tolerance test (OGTT). Plasma glucose and insulin concentrations were measured to determine oral glucose intolerance and the presence of type 2 Diabetes Mellitus according to 2006 American Diabetes Association guidelines (10). All subjects were screened on medical issues and excluded if any gastrointestinal, neurological or renal diseases were present.

Subjects were cleared to perform resistance exercise by a cardiologist who examined electrocardiograms (ECG) measured at rest and during submaximal cycling (performed at 70 $\%$ of age-predicted heart rate max). The subjects were then familiarized with the exercise equipment and physical activity protocol and one repetition maximum (1RM) was estimated on the leg press, leg extension, lateral pulldown and chest press exercise machines using the multiple repetitions testing procedure (19).

\section{Diet and physical activity}

All volunteers were instructed to refrain from any exhaustive physical activity and to keep their diet as consistent as possible for $72 \mathrm{~h}$ prior to the trial. Subjects filled in dietary records 
for $48 \mathrm{~h}$ immediately before the experimental trial. Subjects consumed $8.7 \pm 0.3 \mathrm{MJ} \cdot$ day $^{-1}$ on average, consisting of $49 \pm 1$ energy \% (En\%) as carbohydrate, $32 \pm 1 \mathrm{En} \%$ as fat, and $17 \pm$ $1 \mathrm{En} \%$ as protein. Habitual dietary protein intake averaged $1.11 \pm 0.04 \mathrm{~g} \cdot \mathrm{kg}^{-1} \cdot \mathrm{day}^{-1}$. On the evening prior to the experiment, all subjects consumed a standardized meal $(21.6 \pm 0.4$ $\mathrm{kJ} \cdot \mathrm{kg}^{-1}$, providing $55 \mathrm{En} \%$ as carbohydrate, $25 \mathrm{En} \%$ as fat, and $20 \mathrm{En} \%$ as protein).

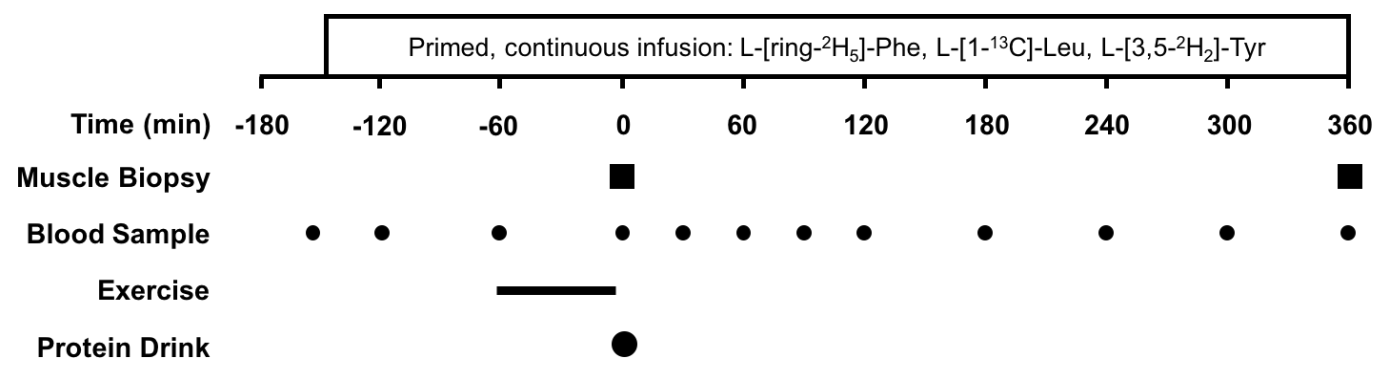

Figure 2.1 Graphical representation of the experimental protocol.

\section{Experimental protocol}

A graphical representation of the study protocol is presented in Figure 2.1. At $0800 \mathrm{~h}$, participants reported to the laboratory in an overnight fasted and rested state and had Teflon catheters inserted into a vein in the antecubital space of one arm and a vein on the dorsal side of the opposite hand for intravenous infusion and arterialized blood sampling, respectively. At $0830 \mathrm{~h}(t=-150 \mathrm{~min})$, a background blood sample was taken prior to the initiation of the tracer infusion protocol. The plasma and intracellular phenylalanine and leucine pools were primed with a single intravenous dose (priming dose) of L-[ring- $\left.{ }^{2} \mathrm{H}_{5}\right]$ phenylalanine $\left(3.6 \mu \mathrm{mol} \cdot \mathrm{kg}^{-1}\right), \mathrm{L}-\left[\mathrm{ring}_{-}{ }^{2} \mathrm{H}_{2}\right]$-tyrosine $\left(1.10 \mu \mathrm{mol} \cdot \mathrm{kg}^{-1}\right), \mathrm{L}-\left[1{ }^{13} \mathrm{C}\right]$-leucine $(7.19$ $\mu \mathrm{mol} \cdot \mathrm{kg}^{-1}$ ). Once primed, the continuous stable isotope infusion was initiated (infusion rate: $0.06 \mu \mathrm{mol} \cdot \mathrm{kg}^{-1} \cdot \mathrm{min}^{-1} \mathrm{~L}$-[ ring- $\left.{ }^{2} \mathrm{H}_{5}\right]$-phenylalanine, $0.018 \mu \mathrm{mol} \cdot \mathrm{kg}^{-1} \cdot \mathrm{min}^{-1} \mathrm{~L}$-[ring- $\left.{ }^{2} \mathrm{H}_{2}\right]$-tyrosine, $0.12 \mu \mathrm{mol} \cdot \mathrm{kg}^{-1} \cdot \mathrm{min}^{-1} \mathrm{~L}-\left[1{ }^{13} \mathrm{C}\right]$-leucine; Cambridge Isotopes Laboratories, Andover, MA). Participants rested for $1.5 \mathrm{~h}$ until $1000 \mathrm{~h}$ ( $t=-60 \mathrm{~min}$ ), at which time the participants completed the resistance exercise bout. After completing the resistance exercise bout, at $1100 \mathrm{~h}$ ( $t=0 \mathrm{~min}$ ), a blood sample was taken and a muscle biopsy was collected from a randomized leg. Subsequently, subjects ingested a $500 \mathrm{~mL}$ beverage containing either: 0 , 15,30 or $45 \mathrm{~g}$ intrinsically $\mathrm{L}-\left[1-{ }^{13} \mathrm{C}\right]$-phenylalanine and L- $\left[1-{ }^{13} \mathrm{C}\right]$-leucine labeled milk protein with an added $1.5 \mathrm{~mL}$ of vanilla extract to improve palatability (Dr. Oetker, Amersfoort, the Netherlands). Protein intakes represent the actual amount of protein provided in the MPC80. Blood samples $(10 \mathrm{~mL})$ were subsequently taken at $t=30,60,90,120,180,240,300,360$ min after protein ingestion. A second muscle biopsy was obtained from the contralateral leg at $1700 \mathrm{~h}$ ( $t=360 \mathrm{~min}$ ), signifying the end of the experimental trial. Blood and muscle samples were collected and stored as previously described (14). 


\section{Resistance exercise protocol}

The exercise protocol consisted of $60 \mathrm{~min}$ of moderate-to-high intensity resistance exercise. After 10 min of cycling at $100 \mathrm{~W}$ with a cadence of $60-80$ RPM, subjects performed 5 sets of 10 repetitions on the horizontal leg press machine (Technogym BV, Rotterdam, Netherlands), 2 sets of 10 repetitions on the lateral pull down machine (Technogym BV), 2 sets of 10 repetitions on the chest press machine (Technogym BV) and 5 sets of 10 repetitions on the leg extension machine (Technogym BV). The first set of each lower body exercise was performed at $50 \% 1 \mathrm{RM}$ and sets 2-5 were performed at 75-80 \% 1RM. All sets of the upper body exercises were performed at 75-80 \% 1RM. Subjects were allowed to rest for $2 \mathrm{~min}$ between sets.

Preparation of tracer and production of intrinsically-labeled protein

The stable isotope tracers L-[ring $\left.-{ }^{2} \mathrm{H}_{5}\right]$-phenylalanine, L-[1- $\left.-{ }^{13} \mathrm{C}\right]$-leucine and L-[ring $\left.{ }^{2} \mathrm{H}_{2}\right]-$ tyrosine were prepared as previously described (14). Intrinsically L-[1- $\left.{ }^{13} \mathrm{C}\right]$-phenylalanine and $\mathrm{L}-\left[1-{ }^{13} \mathrm{C}\right]$-leucine labeled milk protein (MPC80) was extracted from whole milk obtained during the constant infusion of $\mathrm{L}-\left[1-{ }^{13} \mathrm{C}\right]$-phenylalanine $\left(455 \mu \mathrm{mol} \cdot \mathrm{min}^{-1}\right)$ and $\mathrm{L}-\left[1-{ }^{13} \mathrm{C}\right]$-leucine $\left(200 \mu \mathrm{mol} \cdot \mathrm{min}^{-1}\right)$ for $96 \mathrm{~h}$ in a lactating dairy cow. The milk was collected, processed, and fractionated into the MPC80 similarly to what has been previously described $(11,31,33)$. The $\mathrm{L}-\left[1-{ }^{13} \mathrm{C}\right]$-phenylalanine and $\mathrm{L}-\left[1-{ }^{13} \mathrm{C}\right]$-leucine enrichments in MPC 80 averaged 38.3 mole percent excess (MPE) and $10.8 \mathrm{MPE}$, respectively. The protein met all chemical and bacteriological specifications for human consumption.

\section{Plasma analysis}

Plasma glucose and insulin concentrations were analyzed using commercially available kits (GLUC3, Roche, Ref: 05168791 190, and Immunologic, Roche, Ref: 12017547 122, respectively). Plasma amino acid concentrations and enrichments were determined by gas chromatography-mass spectrometry analysis (GC-MS; Agilent 7890A GC/5975C; MSD, Wilmington, Delaware, USA). Specifically, internal standards of $\left[\mathrm{U}-{ }^{13} \mathrm{C}_{6}\right]$-leucine, $\left[\mathrm{U}-{ }^{13} \mathrm{C}_{9}{ }^{15} \mathrm{~N}\right]-$ phenylalanine, and $\left[\mathrm{U}-{ }^{13} \mathrm{C}_{9}{ }^{15} \mathrm{~N}\right]$-tyrosine were added to the plasma samples. Plasma samples were deproteinized with dry 5 -sulfosalicylic acid. Free amino acids were purified using cation exchange chromatography (AG 50W-X8 resin, mesh size: 100-200 $\mu \mathrm{m}$, ionic form: hydrogen; Bio-Rad Laboratories, Hercules, CA). The purified amino acids were converted into tertbutyldimethylsilyl (tert-BDMS) derivatives with MTBSTFA before analysis by GC-MS. The amino acid concentrations were determined using electron impact ionization by monitoring ions at mass/charge $(\mathrm{m} / \mathrm{z}) 302$ and 308 for unlabeled and [U- $\left.{ }^{13} \mathrm{C}_{6}\right]$ labeled-leucine, 336 and 346 for unlabeled and $\left[\mathrm{U}-{ }^{13} \mathrm{C}_{9}{ }^{15} \mathrm{~N}\right]$ labeled phenylalanine respectively, and 466 and 476 for 
unlabeled and $\left[\mathrm{U}-{ }^{13} \mathrm{C}_{9}{ }^{15} \mathrm{~N}\right]$ labeled tyrosine, respectively. The plasma leucine, phenylalanine, and tyrosine ${ }^{13} \mathrm{C}$ and ${ }^{2} \mathrm{H}$ enrichments were determined using selective ion monitoring at $\mathrm{m} / \mathrm{z}$ 302 and 303 for unlabeled and labeled $\left[1-{ }^{13} \mathrm{C}\right]$ leucine, respectively; $\mathrm{m} / \mathrm{z} 336,337$, and 341

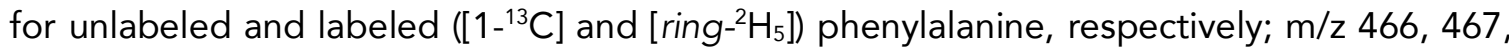
468, and 470 for unlabeled and labeled $\left(\left[1-{ }^{13} \mathrm{C}\right]\right.$, [ring $\left.-3,5-{ }^{2} \mathrm{H}_{2}\right]$, and [ring $\left.\left.-{ }^{2} \mathrm{H}_{4}\right]\right)$ tyrosine, respectively. Standard regression curves were applied from a series of known standard enrichment values against the measured values to assess the linearity of the mass spectrometer and to account for any isotope fractionation.

\section{Muscle analysis}

Myofibrillar protein enriched fractions were extracted from $\sim 60 \mathrm{mg}$ of wet muscle tissue by hand-homogenizing on ice using a pestle in a standard extraction buffer $\left(7 \mu \mathrm{L} \cdot \mathrm{mg}^{-1}\right)$ (13). The samples were spun at $2500 \mathrm{~g}$ and $4{ }^{\circ} \mathrm{C}$ for $5 \mathrm{~min}$. The pellet was washed with $500 \mu \mathrm{L} \mathrm{ddH} 2 \mathrm{O}$ and centrifuged at $250 \mathrm{~g}$ and $4{ }^{\circ} \mathrm{C}$ for $10 \mathrm{~min}$. The myofibrillar protein was solubilized by adding $1 \mathrm{~mL}$ of $0.3 \mathrm{M} \mathrm{NaOH}$ and heating at $50{ }^{\circ} \mathrm{C}$ for $30 \mathrm{~min}$ with vortex mixing every 10 min. Samples were centrifuged at $9500 \mathrm{~g}$ and $4{ }^{\circ} \mathrm{C}$ for $5 \mathrm{~min}$, the supernatant containing the myofibrillar proteins was collected and the collagen pellet was discarded. Myofibrillar proteins were precipitated by the addition of $1 \mathrm{~mL}$ of $1 \mathrm{M} \mathrm{PCA}$ and spinning at $700 \mathrm{~g}$ and 4 ${ }^{\circ} \mathrm{C}$ for $10 \mathrm{~min}$. The myofibrillar protein was washed twice with $70 \%$ ethanol and hydrolyzed overnight in $2 \mathrm{~mL}$ of $6 \mathrm{M} \mathrm{HCL}$ at $110^{\circ} \mathrm{C}$. The free amino acids from the hydrolyzed myofibrillar protein pellet were dried under a nitrogen stream while being heated to $120^{\circ} \mathrm{C}$. The free amino acids were then dissolved in $25 \%$ acetic acid solution, passed over cation exchange AG 50W-X8 resin columns (mesh size: 100-200, ionic form: hydrogen; Bio-Rad Laboratories, Hercules, $\mathrm{CA}$ ), and eluted with $2 \mathrm{M} \mathrm{NH}_{4} \mathrm{OH}$. The purified amino acids were divided into 2 aliquots to determine the L-[ring- ${ }^{2} \mathrm{H}_{5}$ ]-phenylalanine enrichments by GC-MS analysis and the $\mathrm{L}-\left[1-{ }^{13} \mathrm{C}\right]$-phenylalanine and $\mathrm{L}-\left[1-{ }^{13} \mathrm{C}\right]$-leucine enrichments by gas chromatography-combustion-isotope ratio mass spectrometry (GC-C-IRMS) analysis. To reduce the signal-to-noise ratio during GC-MS analysis at low tracer enrichments, the phenylalanine from the myofibrillar protein hydrolysates was enzymatically decarboxylated to $\beta$-phenylethylamine prior to derivatization with MTBSTFA. To determine myofibrillar protein L-[1- $\left.{ }^{13} \mathrm{C}\right]$-phenylalanine and L-[ $\left[1-{ }^{13} \mathrm{C}\right]$-leucine enrichments by GC-C-IRMS analysis, the purified amino acids were converted into $\mathrm{N}$-ethoxycarbonyl ethyl ester derivatives with ethyl chloroformate (ECF). The derivatives were then measured by GC-C-IRMS (Finnigan MAT 253, Bremen, Germany) using a DB5-MS-column (no. 122-5532; Agilent J+W scientific GC Column, GC Isolink) and monitoring of ion masses 44,45 and 46 . Standard regression curves were applied to assess the linearity of the mass spectrometer and to account for isotopic fractionation. 


\section{Calculations}

Ingestion of $\mathrm{L}-\left[1-{ }^{13} \mathrm{C}\right]$-phenylalanine labeled protein, intravenous infusion of $\mathrm{L}-\left[\mathrm{ring}_{-}{ }^{2} \mathrm{H}_{5}\right]-$ phenylalanine, and blood sample enrichment values were used to assess whole body amino acid kinetics in non-steady state conditions. Total, exogenous, and endogenous phenylalanine rates of appearance $\left(R_{a}\right)$ and plasma availability of dietary protein-derived phenylalanine that appeared in the systemic circulation as a fraction of total amount of phenylalanine that was ingested, (Phe plasma) were calculated using modified Steele's equations $(3,8,39)$. These parameters were calculated as follows:

$$
\begin{aligned}
& \operatorname{Total} R_{a}=\frac{F_{i v}-\left[p V \cdot C(t) \cdot \frac{d E_{i v}}{d t}\right]}{E_{i v}(t)} \\
& \operatorname{Exo} R_{a}=\frac{\operatorname{Total} R_{a} \cdot E_{p o}(t)+\left[p V \cdot C(t) \cdot \frac{d E_{p o}}{d t}\right]}{E_{p r o t}} \\
& \operatorname{Endo} R_{a}=\operatorname{Total} R_{a}-\operatorname{Exo} R_{a}-F_{i v} \\
& \text { Pheplasma }=\left(\frac{\text { AUC }_{\text {ExoRa }}}{\text { Phe }_{\text {prot }}}\right) \cdot 100
\end{aligned}
$$

where $F_{i v}$ is the intravenous tracer infusion rate $\left(\mu \mathrm{mol} \cdot \mathrm{kg}^{-1} \cdot \mathrm{min}^{-1}\right), p V\left(0.125 \mathrm{~L}^{-} \cdot \mathrm{kg}^{-1}\right)$ is the distribution volume for phenylalanine (3). $C(t)$ is the mean plasma phenylalanine concentration between 2 consecutive time points. $d E_{i v} / d t$ represents the time-dependent variations of plasma phenylalanine enrichment derived from the intravenous tracer and $E_{i v}(t)$ is the mean plasma phenylalanine enrichment from the intravenous tracer between 2 consecutive time points. Exo $R_{\mathrm{a}}$ represents the plasma entry rate of dietary phenylalanine, $E_{p o}$ $(t)$ is the mean plasma phenylalanine enrichment for the ingested tracer, $d E_{p o} / d t$ represents the time-dependent variations of plasma phenylalanine enrichment derived from the oral tracer and $\mathrm{E}_{\text {prot }}$ is the $\mathrm{L}-\left[1-{ }^{13} \mathrm{C}\right]$-phenylalanine enrichment in the dietary protein. Phe plasma is the percentage of ingested dietary phenylalanine that becomes available in the plasma and is

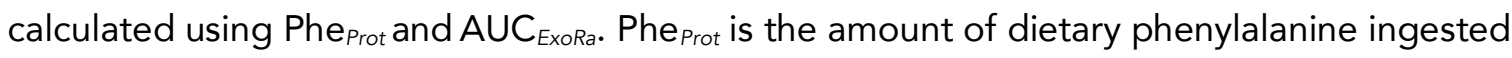
and $A \cup C_{\text {ExoRa }}$ represents the area under the curve $(A \cup C)$ of Exo $R_{a}$, which corresponds to the amount of dietary phenylalanine that appeared in the blood over a $7.5 \mathrm{~h}$ period following ingestion.

Total rate of disappearance of phenylalanine (TotalR $R_{d}$ ) equals the rate of phenylalanine hydroxylation (first step in phenylalanine oxidation) and utilization for protein synthesis. This parameter is calculated as follows:

$$
\mathrm{R}_{\mathrm{d}}=\text { TotalR }_{\mathrm{a}}-\mathrm{pV} \cdot \frac{\mathrm{dC}}{\mathrm{dt}}
$$


Whole-body phenylalanine oxidation can be determined from the conversion (hydroxylation) of $\mathrm{L}$-[ ring- $\left.{ }^{2} \mathrm{H}_{5}\right]$-phenylalanine to $\mathrm{L}-\left[\right.$ ring- $\left.{ }^{2} \mathrm{H}_{4}\right]$-tyrosine. The rate of phenylalanine hydroxylation was calculated by using the following formula:

$$
\mathrm{Phe}_{\text {hydroxylation }}=\operatorname{Tyr} R_{a} \cdot \frac{\mathrm{E}_{\mathrm{t}}(\mathrm{t})}{\mathrm{E}_{\mathrm{p}}(\mathrm{t})} \cdot \frac{\mathrm{PheR}_{d}}{\left(\mathrm{~F}_{\mathrm{iv}}+\mathrm{PheR}_{d}\right)}
$$

Because whole body $R_{d}$ comprises the rate of phenylalanine disappearance from the free amino acid pool in the blood due to protein synthesis $(S)$ and oxidation, whole body protein synthesis can be calculated as $R_{d}$ minus $\mathrm{Phe}_{\text {hydroxylation }}$ (oxidation). Tyr $R_{a}$ represents the rate of appearance of $\mathrm{L}-\left[\right.$ ring- ${ }^{2} \mathrm{H}_{4}$ ]-tyrosine; $\mathrm{E}_{\mathrm{t}}(\mathrm{t})$ and $\mathrm{E}_{p}(\mathrm{t})$ are the $\mathrm{L}$-[ ring- $\left.{ }^{2} \mathrm{H}_{4}\right]$-tyrosine and $\mathrm{L}$ - $\left[\right.$ ring $\left._{-}{ }^{2} \mathrm{H}_{5}\right]$ phenylalanine enrichments in plasma between 2 consecutive time points, respectively and Fiv is the infusion rate of phenylalanine. Whole body protein synthesis was calculated using:

$$
S=R_{d}-\text { Phe }_{\text {hydroxylation }}
$$

Whole body protein net balance was calculated as AUC over the $7.5 \mathrm{~h}$ post-prandial phase using whole body protein synthesis minus endogenous $R_{a}$.

$$
\text { Phe }_{\text {net balance }}=S-\text { Endo }_{R a}
$$

The fractional synthesis rate (FSR) of myofibrillar protein was calculated by dividing the increment in enrichment in the product (i.e., protein-bound L- $\left[1-{ }^{13} \mathrm{C}\right]$-leucine or L-[ring- $\left.{ }^{2} \mathrm{H}_{5}\right]-$ phenylalanine) by the enrichment of the respective precursor amino acid enrichments (i.e., plasma free amino acids). Weighted mean plasma L-[ring- $\left.{ }^{2} \mathrm{H}_{5}\right]$-phenylalanine and L- $\left[1-{ }^{13} \mathrm{C}\right]-$ leucine enrichments were used as the preferred precursor pools to estimate myofibrillar protein fractional synthesis rates from the continuously infused $\mathrm{L}-\left[\right.$ ring- $\left.{ }^{2} \mathrm{H}_{5}\right]$-phenylalanine, and L-[1-13 C]-leucine tracers. Consequently, myofibrillar FSR was calculated as follows (39):

$$
\operatorname{FSR}\left(\% \cdot \mathrm{h}^{-1}\right)=\left(\frac{E_{m 2}-E_{m 1}}{E_{\text {precursor }} \times t}\right) \times 100
$$

$E_{m 2}-E_{m 1}$ represents the change in muscle protein bound L- $\left[1-{ }^{13} \mathrm{C}\right]$-leucine enrichment. $E_{\text {precursor }}$ represents the average plasma $\mathrm{L}-\left[1-{ }^{13} \mathrm{C}\right]$-leucine, $\alpha-\left[1-{ }^{13} \mathrm{C}\right]-\mathrm{KIC}$ or muscle free $\mathrm{L}-\left[1-{ }^{13} \mathrm{C}\right]$-leucine enrichment during the tracer incorporation period. $t$ indicates the time interval $(h)$ between biopsies. 


\section{Statistics}

A sample size of 48 ( 12 subjects per group) was calculated a priori based upon an effect size of 0.5 for FSR between groups $(27,28)$, a significance level of 0.05 , and a power of 0.8 . All data are expressed as means \pm SEMs. Baseline characteristics between groups were compared using a one-way ANOVA. A two-factor repeated measures ANOVA (time $x$ treatment) with time as within-subjects factor and treatment group as between-subjects factor was performed for the analysis of plasma glucose and insulin concentrations, plasma amino acid concentrations, plasma tracer enrichments and whole-body protein kinetics. The analysis was carried out for the period starting at the time of protein administration, between $t=0$ and $360 \mathrm{~min}$. Only upon identification of a significant time $\mathrm{x}$ treatment interaction, separate analyses were performed using a one-way ANOVA with Tukey post hoc testing to identify time points in which the treatments differed, and one-way repeated measures ANOVA to identify changes over time within the separate groups. Non time-dependent variables (i.e., whole-body protein metabolism, FSR values, L-[1- $\left.{ }^{13} \mathrm{C}\right]-$ phenylalanine myofibrillar enrichments, area under the curve, peak values) were compared between treatment groups using a one-way ANOVA. If a significant group effect was detected using the one-way ANOVA, Tukey post hoc testing was used to identify how the groups significantly differed from one another. Statistical significance was set at $P<0.05$. All calculations were performed using SPSS 21.0 (IBM, Chicago, Illinois, USA). 


\section{Results}

\section{Plasma concentrations}

Plasma glucose (Figure 2.3A) concentrations decreased after beverage ingestion $(P<$ $0.001)$, but did not differ between groups $(P=0.325)$. Plasma insulin concentrations (Figure 2.3B) increased rapidly following protein ingestion $(P<0.001)$ and were significantly greater at $t=30$ in the $45 \mathrm{G}$ group when compared to PLA $(P=0.002)$.

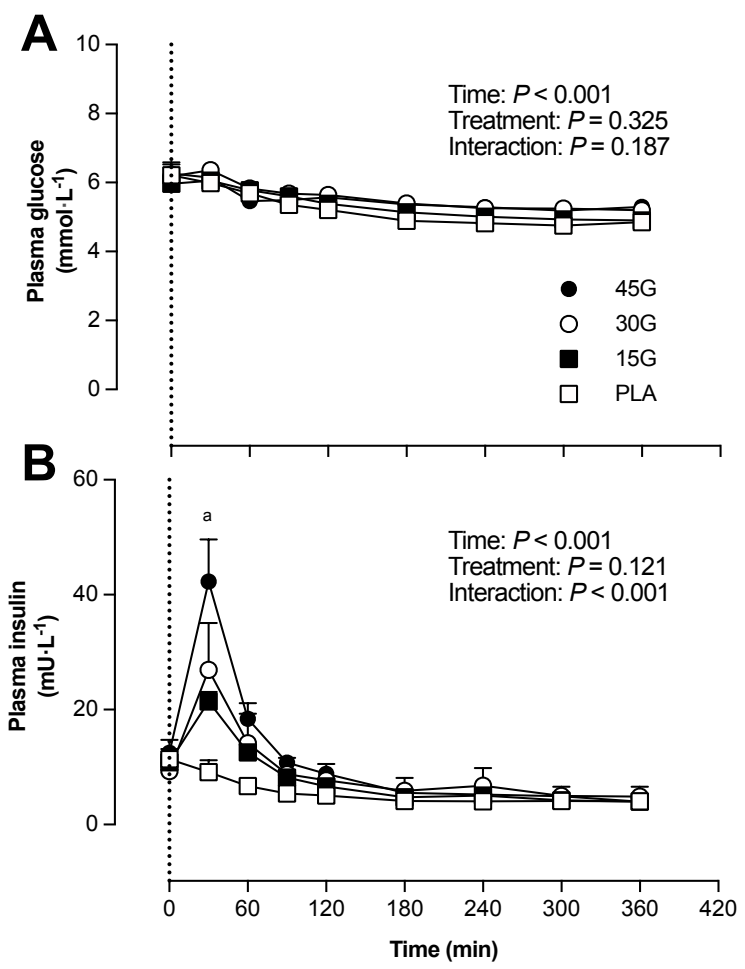

Figure 2.3 Plasma glucose (A) and insulin (B) concentrations following ingestion of O (PLA; $n=12), 15$ (15G; $n$ = 12), 30 (30G; $n=12) 45$ (45G; $n=12) \mathrm{g}$ of milk protein concentrate after resistance exercise in older men. The dotted line represents the ingestion of the beverage. Values represent means + SEM. Data were analyzed with a repeated measure (time $x$ treatment group) ANOVA and separate analyses when a significant interaction was detected (see Materials and methods section). ${ }^{a}$ Significant difference from PLA within same time point (P

Plasma leucine concentrations (Figure 2.4A) increased rapidly following protein ingestion ( $P$ $<0.001)$, but were greater in $45 \mathrm{G}$ when compared to $30 \mathrm{G}$ and $15 \mathrm{G}(P<0.001)$. Area under the curve (AUC) analyses (Figure 2.4B) revealed that plasma leucine availability over the $6 \mathrm{~h}$ post-prandial period increased in a dose-dependent manner based upon the amount of protein ingested $(P<0.001)$. Plasma phenylalanine concentrations (Figure $2.4 \mathrm{C}$ ) increased rapidly following protein ingestion $(P<0.001)$, but were greater in the $45 \mathrm{G}$ group when compared to 30G and 15G at $t=30,60,90 \mathrm{~min}$ (all $P<0.05$ ). Plasma tyrosine concentrations (Figure 2.4D) increased following protein ingestion $(P<0.001)$ and were higher in $45 \mathrm{G}$ when compared to PLA at $t=30,60,90,120,180,240 \mathrm{~min}$ (all $P<0.01$ ). 


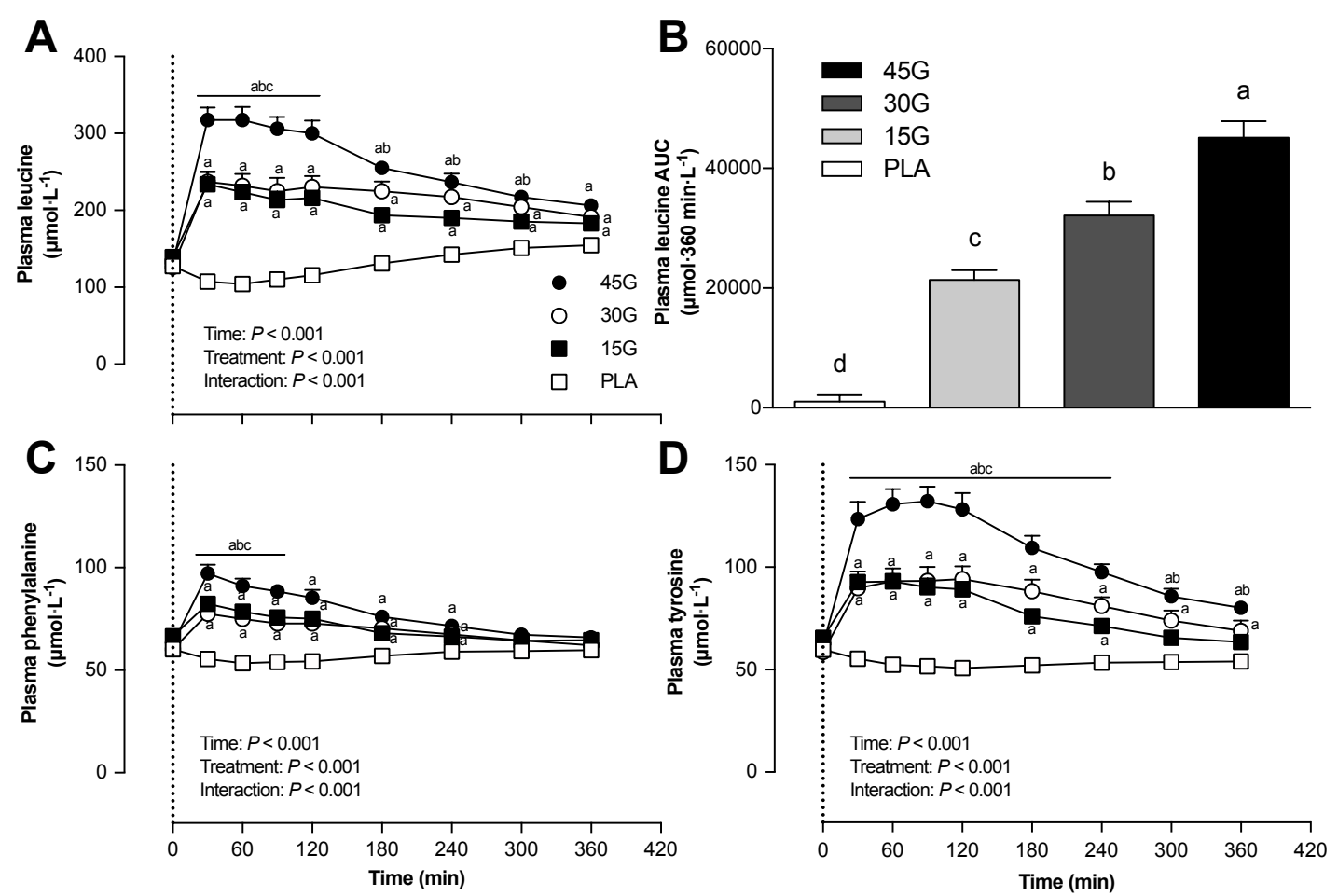

Figure 2.4 Plasma leucine (A), phenylalanine (C) and tyrosine (D) concentrations following ingestion of $O$ (PLA), 15 (15G), 30 (30G), or 45 (45G) g of milk protein concentrate after resistance exercise in older men. The dotted line represents the ingestion of the beverage. Values represent means $+S E M s, n=12$. Data were analyzed with repeated measures (time $x$ treatment group) ANOVA and separate analyses when a significant interaction was detected (see Materials and methods section). ${ }^{a}$ Different from PLA at that time $(P<0.05)$. ${ }^{b}$ Different from $15 G$ at that time $(P<0.05)$. ${ }^{\circ}$ Different from $30 G$ at that time $(P<0.05)$. Plasma leucine area under the curve $(B)$ over $360 \mathrm{~min}\left(\mu \mathrm{mol} \cdot 360 \mathrm{~min} \cdot \mathrm{L}^{-1}\right)$ were analyzed using a one-way ANOVA. Tukey post-hoc testing was used to detect differences between groups. Labeled means without a common letter differ $(P<0.05)$.

\section{Plasma amino acid enrichments}

Plasma enrichments from ingested $\left(\mathrm{L}-\left[1-{ }^{13} \mathrm{C}\right]\right.$-phenylalanine; Figure 2.5A), infused (L-[ring$\left.{ }^{2} \mathrm{H}_{5}\right]$-phenylalanine; Figure 2.5B) and ingested and infused $\left(\mathrm{L}-\left[1-{ }^{13} \mathrm{C}\right]\right.$-leucine; Figure $\left.2.5 \mathrm{C}\right)$ amino acid tracers did not differ between treatments prior to protein ingestion ( $t=0 \mathrm{~min} ; P$ $>0.05$ for all tracers). After protein ingestion, plasma L- $\left[1-{ }^{13} \mathrm{C}\right]$-phenylalanine enrichments, originating from the ingested protein, increased in all protein groups reaching peak values at $t=60 \mathrm{~min}$ in $15 \mathrm{G}, t=120 \mathrm{~min}$ in $30 \mathrm{G}$ and $t=90 \mathrm{~min}$ in $45 \mathrm{G}$. The plasma $\mathrm{L}-\left[1{ }^{13} \mathrm{C}\right]-$ phenylalanine enrichments in 15G were greater than enrichments in PLA until $t=360 \mathrm{~min}$ ( $P$ $=0.122)$. The increases in plasma $\mathrm{L}-\left[1-{ }^{13} \mathrm{C}\right]$-phenylalanine enrichments in $30 \mathrm{G}$ and $45 \mathrm{G}$ were sustained above PLA for the duration of the $6 \mathrm{~h}$ post-prandial period $(P<0.001$ for all time points). Plasma L-[ring- $\left.{ }^{2} \mathrm{H}_{5}\right]$-phenylalanine enrichments were higher in PLA when compared to the protein groups $(P<0.001)$ until $t=240 \mathrm{~min}$ when compared to $15 \mathrm{G}$ and $\mathrm{t}=300 \mathrm{~min}$ when compared to $30 \mathrm{G}$ and $45 \mathrm{G}$. Plasma L- $\left[1-{ }^{13} \mathrm{C}\right]$-leucine enrichments were lower in the PLA group when compared to 30G $(P=0.040)$ and 45G $(P<0.001)$ and were also lower in $15 \mathrm{G}$ when compared to $45 \mathrm{G}(P=0.010)$. 


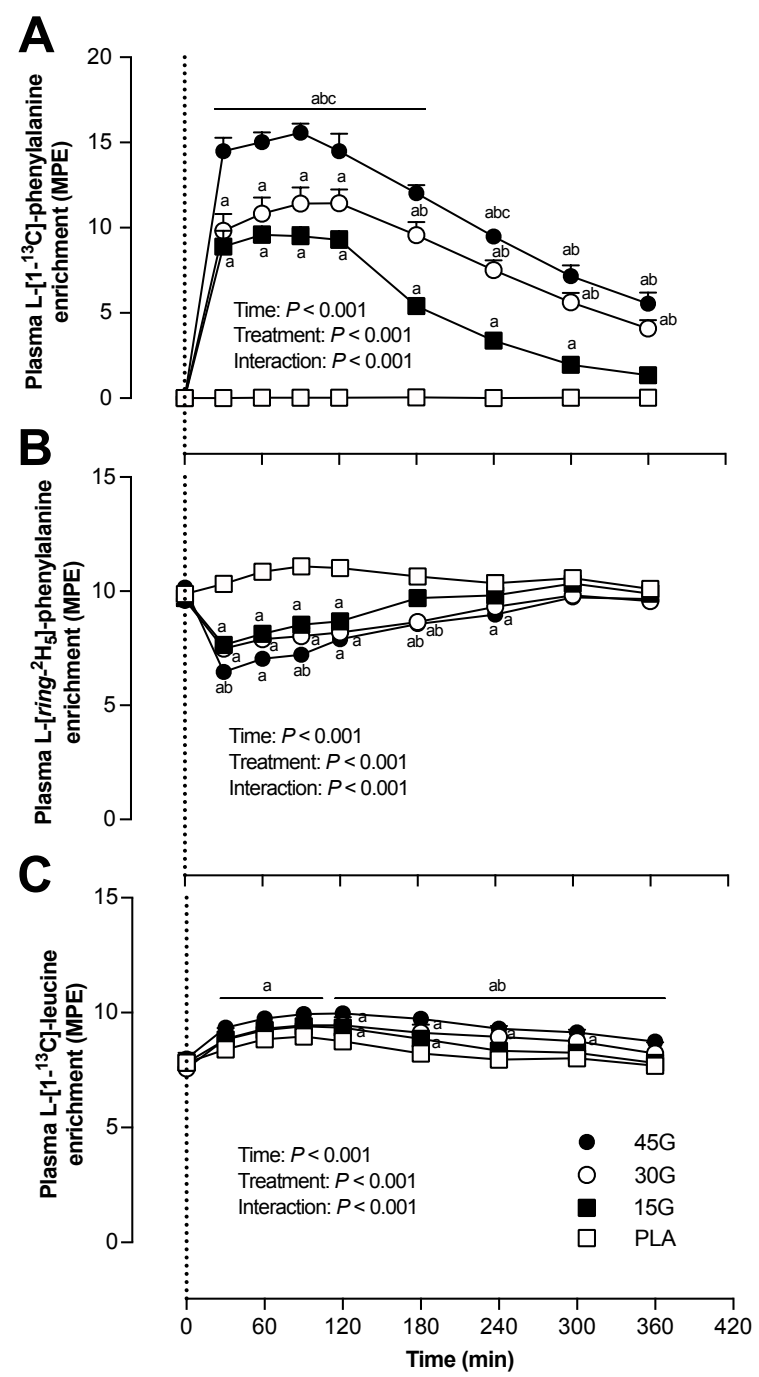

Figure 2.5 Plasma L-[1-13 C]-phenylalanine (A), L-[ring- $\left.{ }^{2} \mathrm{H}_{5}\right]$-phenylalanine (B), L-[1- $\left.{ }^{13} \mathrm{C}\right]$-leucine (C) enrichments following ingestion of 0 (PLA), 15 (15G), 30 (30G), or 45 (45G) g of milk protein concentrate after resistance exercise in older men. The dotted line represents the ingestion of the beverage. Values represent means + $S E M s, n=12$. Data were analyzed with repeated measures (time $x$ treatment group) ANOVA and separate analyses when a significant interaction was detected (see Materials and methods section). ${ }^{a}$ Different from PLA at that time $(P<0.05)$. ${ }^{b}$ Different from $15 G$ at that time $(P<0.05)$. ${ }^{c}$ Different from $30 G$ at that time $(P<0.05)$.

Whole-body amino acid kinetics

Endogenous phenylalanine rates of appearance (Figure 2.6A) were significantly lower after protein intake in $45 \mathrm{G}$ when compared with PLA $(P=0.018)$. Exogenous phenylalanine rates of appearance (Figure 2.6B) increased following protein intake in all protein groups $(P<$ $0.001)$, and were higher in $45 \mathrm{G}$ when compared to $15 \mathrm{G}$ and $30 \mathrm{G}(P<0.001)$.

Dietary protein-derived phenylalanine availability, calculated as a fraction of the total amount of ingested phenylalanine (Figure 2.7A), was higher in $15 \mathrm{G}$ when compared to $30 \mathrm{G}$ and $45 \mathrm{G}$ $(P<0.001$ for both). The absolute amount of dietary protein-derived phenylalanine that appeared in the circulation during the $6 \mathrm{~h}$ post-prandial period (Figure 2.7B) responded in 
a dose-dependent manner, with significant differences detected between each group $(P<$ 0.001).

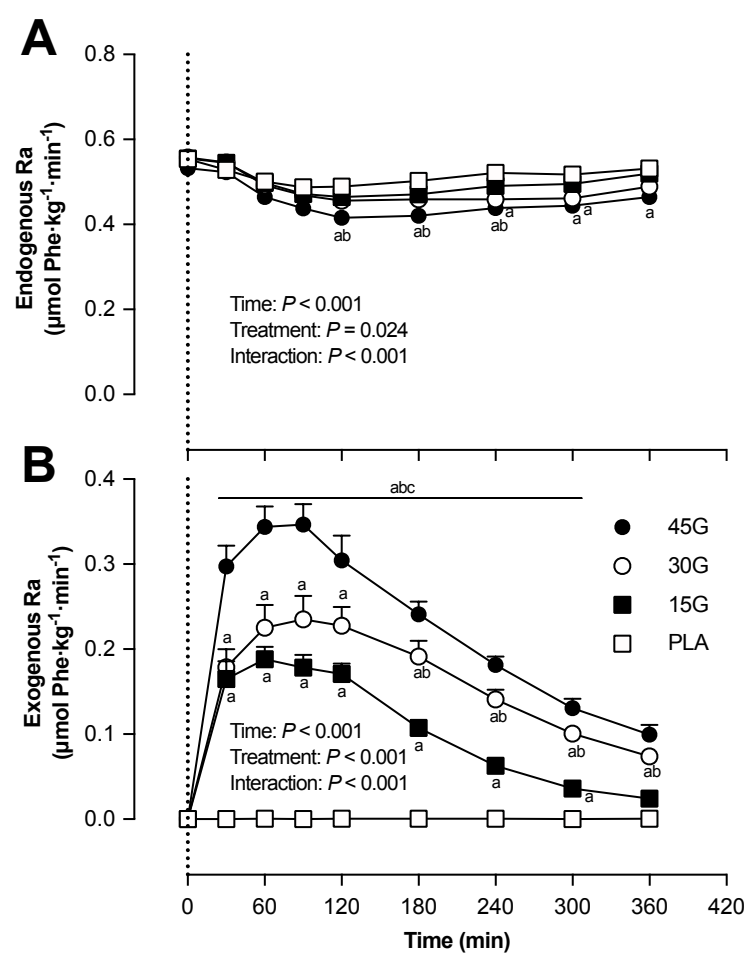

Figure 2.6 Endogenous phenylalanine rate of appearance $(R a)(A)$ and exogenous phenylalanine $R a(B)$ following ingestion of 0 (PLA), 15 (15G), 30 (30G), or 45 (45G) g of milk protein concentrate after resistance exercise in older men. The dotted line represents the ingestion of the beverage. Values represent means + SEMs, $n=12$. Data were analyzed with repeated measures (time $x$ treatment group) ANOVA and separate analyses when a significant interaction was detected (see Materials and methods section). Tukey post-hoc testing was used to detect differences between groups. ${ }^{a}$ Different from PLA at that time $(P<0.05)$. ${ }^{b}$ Different from $15 G$ at that time $(P<0.05)$. ${ }^{c}$ Different from $30 G$ at that time $(P<0.05)$.

Whole-body protein synthesis rates increased after protein ingestion ( $P<0.01$ for all groups), with greater rates in 45G when compared with 15G (15G: $0.60 \pm 0.01,30 \mathrm{G}: 0.64 \pm 0.01$ 45G: $\left.0.66 \pm 0.02 \mu \mathrm{mol} P h e \cdot \mathrm{kg}^{-1} \cdot \mathrm{min}^{-1}, P=0.038\right)$. Whole-body protein breakdown rates were lower in $45 \mathrm{G}\left(0.45 \pm 0.01 \mu \mathrm{mol} P h e \cdot \mathrm{kg}^{-1} \cdot \mathrm{min}^{-1}\right)$ when compared to PLA $(0.51 \pm 0.02 \mu \mathrm{mol}$ Phe $\cdot \mathrm{kg}$ $\left.{ }^{1} \cdot \mathrm{min}^{-1}, P=0.004\right)$. Whole-body protein oxidation rates were greater in $45 \mathrm{G}(0.060 \pm 0.003$ $\mu \mathrm{mol}$ Phe $\left.\cdot \mathrm{kg}^{-1} \cdot \mathrm{min}^{-1}\right)$ when compared with PLA $\left(0.046 \pm 0.002 \mu \mathrm{mol}\right.$ Phe $\left.\cdot \mathrm{kg}^{-1} \cdot \mathrm{min}^{-1}, P=0.002\right)$ and 15G (0.049 $\left.\pm 0.013 \mu \mathrm{mol} \mathrm{Phe} \mathrm{kg}^{-1} \cdot \mathrm{min}^{-1}, P=0.034\right)$. In all protein groups, whole-body net protein balance (Figure 2.8) was positive during the $6 \mathrm{~h}$ post prandial period and greater when compared to PLA ( $P<0.001$ for all protein groups), with a higher net balance observed in $45 \mathrm{G}$ when compared to $30 \mathrm{G}$ and $15 \mathrm{G}(P<0.001)$. Whole-body net protein balance was also higher in $30 \mathrm{G}$ compared with $15 \mathrm{G}(P<0.001)$. 


\section{Chapter 2}
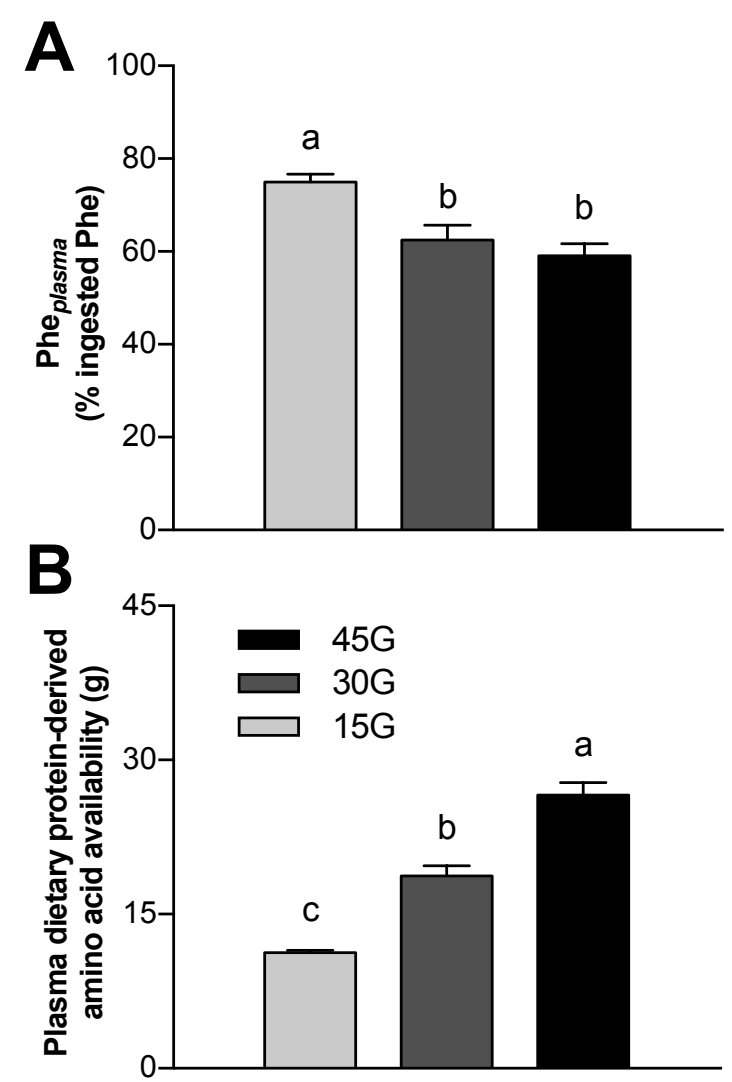

Figure 2.7 Calculated relative plasma phenylalanine availability (Phe plasma, A) of total ingested phenylalanine, and estimated absolute dietary protein-derived amino acid availability (B) following ingestion of 15 (15G), 30 (30G), or 45 (45G) g of milk protein concentrate after resistance exercise in older men. Values represent means + SEMs, $n=12$. Data were analyzed with one-way ANOVA. Tukey post-hoc testing was used to detect differences between groups. Labeled means without a common letter differ $(P<0.05)$.

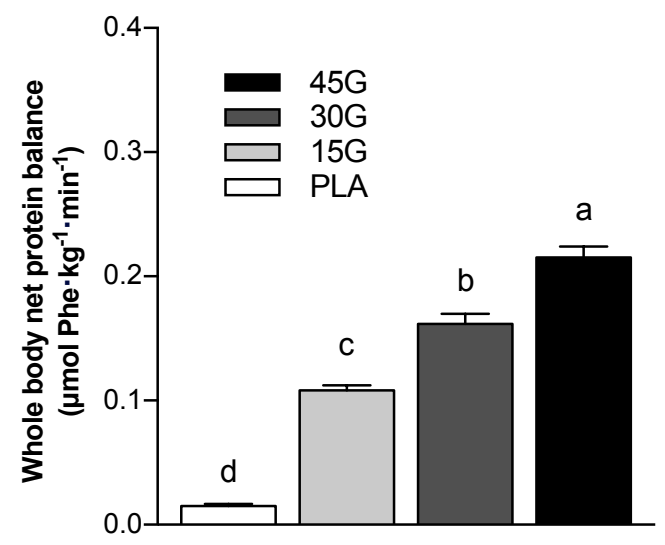

Figure 2.8 Calculated rates of whole-body net protein balance following ingestion of O (PLA), 15 (15G), 30 (30G), or 45 (45G) g of milk protein concentrate after resistance exercise in older men. Values represent means + SEMs, $n=12$. Data were analyzed with one-way ANOVA. Tukey post-hoc testing was used to detect differences between groups. Labeled means without a common letter differ $(P<0.05)$. 
Myofibrillar fractional synthesis rates and protein-bound enrichments

Myofibrillar L-[1-13C]-leucine enrichments were measured in muscle samples collected immediately before protein ingestion and after the $6 \mathrm{~h}$ post-prandial period. The postprandial increase in myofibrillar protein bound L-[1-13 C]-leucine enrichments averaged: $0.0286 \pm 0.0016,0.0314 \pm 0.0016,0.0381 \pm 0.0027,0.0414 \pm 0.0025$ MPE for PLA, 15G, $30 \mathrm{G}$ and 45G, respectively $(P<0.001)$, with higher enrichments in $45 \mathrm{G}$ when compared to PLA $(P=0.001)$ and 15G $(P=0.012)$ and higher enrichments in $30 \mathrm{G}$ when compared to PLA $(P=0.018)$. Myofibrillar protein FSR (in $\left.\% \cdot h^{-1}\right)$ was calculated using the increase in myofibrillar protein bound $\mathrm{L}-\left[1-{ }^{13} \mathrm{C}\right]-$ leucine enrichment and the weighted average of plasma $\mathrm{L}-\left[1-{ }^{13} \mathrm{C}\right]-$ leucine, $\alpha-\left[1-{ }^{13} \mathrm{C}\right]-\mathrm{KIC}$ or tissue free $\mathrm{L}-\left[1-{ }^{13} \mathrm{C}\right]$-leucine enrichment during the tracer incorporation period. Myofibrillar protein FSR calculated using muscle free L- $\left[1-{ }^{13} \mathrm{C}\right]$-leucine was trending to be $28 \%$ greater in $30 \mathrm{G}$ compared with PLA $(P=0.069)$ and $30 \%$ greater in 45G compared with PLA (Figure 2.9; $P=0.040$ ). Myofibrillar protein FSR calculated using plasma L-[1 $\left.-{ }^{13} \mathrm{C}\right]$-Leucine averaged $0.0574 \pm 0.0037,0.0598 \pm 0.0030,0.0700 \pm 0.0048$, and $0.0725 \pm 0.0048 \% \cdot h^{-1}$, for PLA, 15G, 30G and 45G, respectively $(P=0.021)$, with a statistically significant difference detected between PLA and 45G $(P=0.044)$. Myofibrillar protein FSR calculated using plasma $\alpha-\left[1-{ }^{13} \mathrm{C}\right]-\mathrm{KIC}$ averaged $0.0655 \pm 0.0039,0.0649 \pm$ $0.0033,0.0743 \pm 0.0052$, and $0.0747 \pm 0.0052 \% \cdot \mathrm{h}^{-1}$, for PLA, 15G, $30 \mathrm{G}$ and 45G, respectively $(P=0.19)$. L- $\left[1-{ }^{13} \mathrm{C}\right]$-phenylalanine myofibrillar protein-bound enrichments (Figure 2.10) responded in a dose-dependent manner, with a statistically significant difference detected between groups ( $P<0.05$ for each comparison).

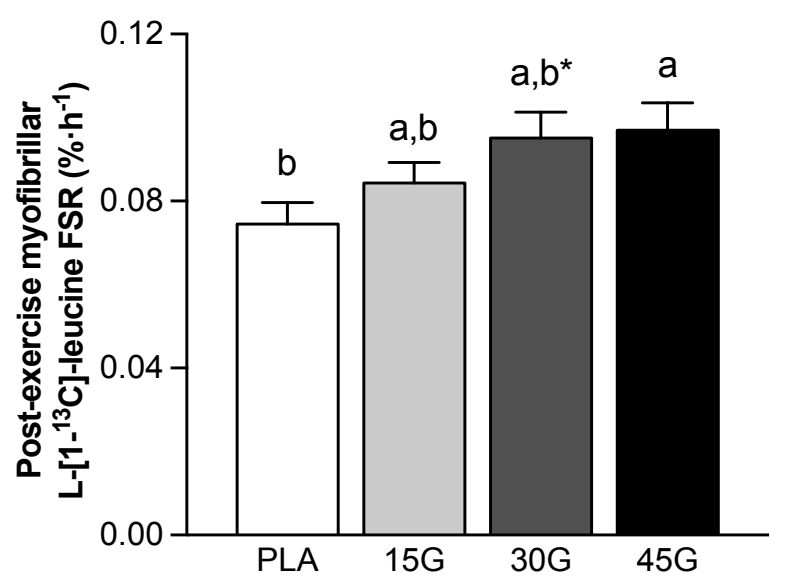

Figure 2.9 Post-exercise myofibrillar protein fractional synthetic rates assessed using $L-\left[1-{ }^{13} \mathrm{C}\right]$-leucine following ingestion of O (PLA), 15 (15G), 30 (30G), or 45 (45G) $\mathrm{g}$ of milk protein concentrate in older men. Values represent means $+S E M s, n=12$. Data were analyzed with one-way ANOVA. Tukey post-hoc testing was used to detect differences between groups. Labeled means without a common letter differ $(P<0.05)$. ${ }^{*}$ Trend for a significant difference $(P<0.10)$ from PLA. 
Chapter 2

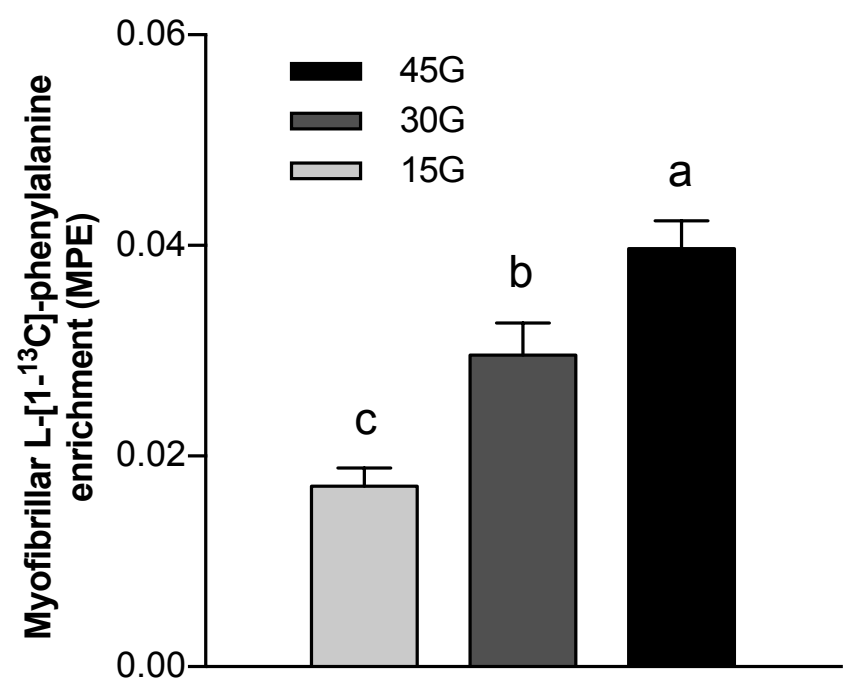

Figure 2.10 L-[1-13 C]-phenylalanine incorporation into myofibrillar protein following ingestion of 15 (15G), 30 (30G), or 45 (45G) g of milk protein concentrate after resistance exercise in older men. Values represent means + SEMs, $n=12$. Data were analyzed with a one-way ANOVA. Tukey post-hoc testing was used to detect differences between groups. Labeled means without a common letter differ $(P<0.05)$. 
Dose response to post-exercise dietary protein ingestion

\section{Discussion}

In the present study, we assessed post-prandial protein digestion and amino acid absorption kinetics, whole body protein metabolism, and the muscle protein synthetic response to the ingestion of different amounts of protein following a single bout of resistance exercise in older men. We observed that protein ingested after resistance exercise was normally digested and absorbed, with $60-75 \%$ of the ingested protein-derived phenylalanine appearing in the circulation throughout a $6 \mathrm{~h}$ post-exercise recovery period. Ingestion of 30 and $45 \mathrm{~g}$ protein resulted in greater post-exercise myofibrillar protein synthesis rates when compared to the ingestion of a placebo. Ingesting greater amounts of protein resulted in more dietary protein-derived phenylalanine being directed towards de novo muscle protein synthesis.

The ingestion of intrinsically $\mathrm{L}-\left[1-{ }^{13} \mathrm{C}\right]-$ phenylalanine labeled protein combined with intravenous administration of $\mathrm{L}-\left[\mathrm{ring}_{-}{ }^{2} \mathrm{H}_{5}\right]$-phenylalanine allowed us to assess dietary protein digestion and amino acid absorption in response to the ingestion of different amounts of protein ingested during recovery from exercise in older men $(4,11)$. Upon protein ingestion, we observed a rapid rise in circulating plasma amino acids concentrations (Figure 2.4) and $\mathrm{L}-\left[1-{ }^{13} \mathrm{C}\right]$-phenylalanine enrichments (Figure 2.5A), demonstrating rapid protein digestion and subsequent absorption of dietary protein derived phenylalanine during post-exercise recovery. Over the entire $6 \mathrm{~h}$ post-exercise recovery period, a total of $75 \pm 2,62 \pm 3$, and 59 $\pm 3 \%$ of the dietary protein-derived phenylalanine was released in the circulation following ingestion of 15,30 , and $45 \mathrm{~g}$ protein, respectively. Previous work has suggested that more dietary-derived amino acids are retained by splanchnic tissues during first-pass when greater amounts of protein are consumed $(3,25,27)$. This is the first study to quantitate the doseresponse to different amounts of phenylalanine ingested as milk protein and the subsequent post-prandial release of dietary protein-derived phenylalanine released in the circulation during recovery from exercise. Based upon labeled phenylalanine, an estimated total of 3.8 $\pm 0.3,11.3 \pm 1.0$ and $18.4 \pm 1.2 \mathrm{~g}$ protein-derived amino acids were not released in the circulation during the $6 \mathrm{~h}$ postprandial period following ingestion of 15, 30 and $45 \mathrm{~g}$ protein, respectively. However, despite greater relative and absolute dietary protein-derived phenylalanine retention, more dietary protein-derived phenylalanine was released following ingestion of the greater amounts of protein (representing an estimated $11.2 \pm 0.3,18.7 \pm$ 1.0 and $26.6 \pm 1.2 \mathrm{~g}$ amino acids following ingestion of 15,30 and $45 \mathrm{~g}$ protein). Consequently, a greater post-prandial rise in plasma amino acid concentrations occurred following ingestion of the greater amounts of protein, with the greatest peak exogenous phenylalanine appearance rates being observed at $t=90 \mathrm{~min}$ after ingestion of $45 \mathrm{~g}$ protein (Figure 2.6B). In line, peak plasma leucine concentrations were greater after ingestion of 45 $g$ protein $\left(317 \pm 16 \mu \mathrm{mol} \cdot \mathrm{L}^{-1}\right)$ compared to ingestion of the other protein doses. Ingestion of greater protein amounts also resulted in greater peak plasma insulin concentrations, with ingestion of $45 \mathrm{~g}$ resulting in the greater peak insulin concentrations compared with placebo 
ingestion (Figure 2.3B). Altogether, these data demonstrate that ingestion of larger amounts of protein allow greater exogenous amino acid availability, resulting in a greater post-prandial rise in plasma leucine and insulin concentrations, which are both important factors driving the post-prandial rise in muscle protein synthesis rates.

Primed continuous infusions of L- $\left[r_{i n g}{ }^{2} \mathrm{H}_{5}\right]$-phenylalanine (and $\left[6,6-{ }^{2} \mathrm{H}_{2}\right]$-tyrosine) allows for the calculation of protein synthesis, breakdown, and oxidation rates on a whole-body level, providing a measure of whole-body protein balance. Protein ingestion increases whole-body net protein balance $(11,12)$. In the present study, protein ingestion resulted in a (more) positive whole-body net protein balance during post-exercise recovery, which further increased when greater amounts of protein were ingested (Figure 2.8). This observation aligns with previous work assessing protein and/or nitrogen balance under resting conditions by our research group (27) as well as others $(17,18,30,36)$, and demonstrates that wholebody net protein balance does not appear to reach an upper limit within the range of protein amounts studied (9). Ingestion of $45 \mathrm{~g}$ protein increased whole-body amino acid oxidation rates when compared with PLA and $15 \mathrm{~g}$ protein. These findings are in line with previous studies conducted in both younger and older individuals $(21,32,38,40)$ and demonstrate that more amino acids are directed towards oxidation following ingestion of larger amounts of protein. It should be noted, however, that the post-prandial rise in whole-body protein synthesis rate, greater whole-body protein balance and whole-body amino acid oxidation do not necessarily reflect the anabolic response in skeletal muscle tissue.

By combining the ingestion of $\mathrm{L}-\left[1-{ }^{13} \mathrm{C}\right]$-leucine labeled milk protein with continuous intravenous $\mathrm{L}-\left[1-{ }^{13} \mathrm{C}\right]$-leucine infusions, we were able to maintain isotopic steady state regardless of the amount of protein ingested (Figure 2.5C). This approach allows for proper comparison of fractional myofibrillar protein synthetic responses between treatment groups (Figure 2.9). Ingestion of $15 \mathrm{~g}\left(\sim 0.19 \mathrm{~g} \cdot \mathrm{kg}^{-1}\right)$ milk protein did not significantly increase postexercise myofibrillar protein synthesis rates when compared to the ingestion of a non-protein placebo. Recent work has shown that healthy older individuals may not be anabolically resistant to the ingestion of a small amount $(6.7 \mathrm{~g})$ of free essential amino acids (representing the amount of essential amino acids in $\sim 20 \mathrm{~g}$ milk protein) under resting conditions (23). Ingestion of free essential amino acids as opposed to intact protein results in a greater and more rapid release of exogenous amino acids into the circulation. Therefore, ingestion of free essential amino acids may provide a more potent anabolic stimulus for skeletal muscle tissue. However, free essential amino acid ingestion is not part of a normal dietary pattern. As such, it is more relevant to compare the present study with others that have provided complete protein sources. For example, the present findings appear to be in contrast with previous work, which has demonstrated that ingestion of $20 \mathrm{~g}\left(\sim 0.25 \mathrm{~g} \cdot \mathrm{kg}^{-1}\right)$ whey protein increases post-exercise muscle protein synthesis rates in healthy older men (40). The apparent discrepancy may be attributed to the smaller amount of protein ingested (15 vs 20 g) and/or the use of a milk protein concentrate, which contains only $20 \%$ whey protein. In the present study, ingestion of $30\left(\sim 0.37 \mathrm{~g}^{\left.\cdot \mathrm{kg}^{-1}\right)}\right.$ and $45 \mathrm{~g}\left(\sim 0.55 \mathrm{~g}^{\left.\cdot \mathrm{kg}^{-1}\right)}\right.$ protein increased 
myofibrillar protein synthesis rates when compared to placebo ingestion. Our findings seem to be in contrast to recent studies conducted in younger men, demonstrating that postexercise muscle protein synthesis rates reach maximal values after ingestion of $20 \mathrm{~g}(\sim 0.25$ $\mathrm{g} \cdot \mathrm{kg}^{-1}$ ) egg (21) or whey (38) protein, with no further increase following ingestion of $40 \mathrm{~g}$ protein. The apparent discrepancy between responses in young and older adults agrees with the concept of anabolic resistance, with older individuals demonstrating a more blunted muscle protein synthetic response to the ingestion of up to $20 \mathrm{~g}\left(\sim 0.25 \mathrm{~g}^{\cdot \mathrm{kg}^{-1}}\right)$ protein in comparison to younger controls $(7,27,35)$. However, as demonstrated here and in two recent studies $(32,40)$, older individuals retain the capacity to increase myofibrillar protein synthesis rates following exercise but seem to require more dietary protein to allow a substantial increase in post-exercise muscle protein synthesis rates when compared to younger individuals.

In the present study, participants ingested specifically produced intrinsically $\mathrm{L}-\left[1-{ }^{13} \mathrm{C}\right]-$ phenylalanine labeled protein at a very high enrichment (38 MPE), allowing us to directly assess the metabolic fate of the dietary protein-derived phenylalanine. We demonstrate that amino acids originating from the ingested protein are utilized for de novo skeletal muscle protein synthesis during post-exercise recovery, as evidenced by the increase in myofibrillar protein bound L-[1- $\left.{ }^{13} \mathrm{C}\right]$-phenylalanine (Figure 2.10). Ingestion of greater amounts of protein resulted in a dose-dependent increase in dietary protein-derived $\mathrm{L}-\left[1-{ }^{13} \mathrm{C}\right]$-phenylalanine incorporation into skeletal muscle protein during post-exercise recovery.

It has been well-established that the anabolic response to protein ingestion is blunted in both healthy $(5,7,35)$ and more clinically compromised older populations, such as those living with sarcopenia $(24,34,35,37)$. This anabolic resistance can be compensated for by combining resistance exercise with protein ingestion (21). Therefore, resistance exercise training and consumption of adequate protein during post-exercise recovery likely represent one of the most effective strategies for counteracting the progression of sarcopenia. The amount of protein ingested after exercise is arguably the key nutritional factor dictating the magnitude of the post-exercise muscle protein synthetic response (38). The present study shows that ingestion of at least $30 \mathrm{~g}\left(\sim 0.37 \mathrm{~g} \mathrm{~kg}^{-1}\right)$ protein results in a measurable rise in post-exercise muscle protein synthesis rates when compared to the placebo, with ingestion of $45 \mathrm{~g}\left(\sim 0.55 \mathrm{~g}^{\circ} \mathrm{kg}^{-1}\right)$ protein providing a greater amount of dietary protein-derived phenylalanine for de novo muscle protein synthesis. Our findings indicate that older men may need to consume well above the much advised $20 \mathrm{~g}\left(\sim 0.25 \mathrm{~g}^{\cdot \mathrm{kg}^{-1}}\right)$ of a high quality protein source (e.g., whey) to substantially increase post-exercise muscle protein synthesis rates $(7,27,35)$. However, ingesting 30-45 $\mathrm{g}\left(\sim 0.37-0.55 \mathrm{~g} \cdot \mathrm{kg}^{-1}\right)$ protein in a single mixed meal may be practically challenging for the older population $(32,40)$. Furthermore, the anabolic response to ingestion of a mixed meal may be modulated by co-ingestion of nondairy protein sources $(5,7,35)$ and interaction of protein with other nutrients $(24,34,35,37)$. Therefore, active older individuals may consider consuming more protein-dense foods 
Chapter 2

and/or fortifying the post-exercise meal with an isolated protein source to ensure protein intake beyond $30 \mathrm{~g}\left(\sim 0.37 \mathrm{~g} \mathrm{~kg}^{-1}\right)$.

In conclusion, dietary protein ingested after resistance exercise is rapidly digested and absorbed, with an estimated $60-75 \%$ of the protein-derived amino acids being released in the circulation following ingestion of 15,30 or $45 \mathrm{~g}$ protein. Whole-body net protein balance and dietary protein-derived amino acid incorporation into myofibrillar protein increase in a dose-dependent manner. Ingestion of at least $30 \mathrm{~g}\left(\sim 0.37 \mathrm{~g}^{\left.\cdot \mathrm{kg}^{-1}\right)}\right.$ protein increases postexercise myofibrillar protein synthesis rates in older men. 
Dose response to post-exercise dietary protein ingestion

\section{References}

1. Baumgartner RN, Waters DL, Gallagher D, Morley JE, Garry PJ. Predictors of skeletal muscle mass in elderly men and women. Mech Ageing Dev 107: 123-136, 1999.

2. Biolo G, Maggi SP, Williams BD, Tipton KD, Wolfe RR. Increased rates of muscle protein turnover and amino acid transport after resistance exercise in humans. Am J Physiol 268: E514-20, 1995.

3. Boirie Y, Gachon P, Corny S, Fauquant J, Maubois JL, Beaufrere B. Acute postprandial changes in leucine metabolism as assessed with an intrinsically labeled milk protein. Am J Physiol 271: E1083-91, 1996.

4. Burd NA, Cermak NM, Kouw IWK, Gorissen SH, Gijsen AP, van Loon LJC. The use of doubly labeled milk protein to measure postprandial muscle protein synthesis rates in vivo in humans. J Appl Physiol 117: 1363-1370, 2014.

5. Burd NA, Gorissen SH, van Loon LJC. Anabolic resistance of muscle protein synthesis with aging. Exerc Sport Sci Rev 41: 169-173, 2013.

6. Churchward-Venne TA, Holwerda AM, Phillips SM, van Loon LJC. What is the Optimal Amount of Protein to Support Post-Exercise Skeletal Muscle Reconditioning in the Older Adult? Sports Med 46: 1205-1212, 2016.

7. Cuthbertson D, Smith K, Babraj J, Leese G, Waddell T, Atherton P, Wackerhage H, Taylor PM, Rennie MJ. Anabolic signaling deficits underlie amino acid resistance of wasting, aging muscle. FASEB J 19: 422424, 2005.

8. Dangin M, Guillet C, Garcia-Rodenas C, Gachon P, Bouteloup-Demange C, Reiffers-Magnani K, Fauquant $\mathrm{J}$, Ballèvre $\mathrm{O}$, Beaufrère $\mathrm{B}$. The rate of protein digestion affects protein gain differently during aging in humans. J Physiol 549: 635-644, 2003.

9. Deutz NE, Wolfe RR. Is there a maximal anabolic response to protein intake with a meal? Clinical Nutrition 32: 309-313, 2013.

10. Genuth S, Alberti KGMM, Bennett $P$, Buse J, Defronzo R, Kahn R, Kitzmiller J, Knowler WC, Lebovitz H, Lernmark A, Nathan D, Palmer J, Rizza R, Saudek C, Shaw J, Steffes M, Stern M, Tuomilehto J, Zimmet $\mathrm{P}$, Expert Committee on the Diagnosis and Classification of Diabetes Mellitus. Follow-up Report on the Diagnosis of Diabetes Mellitus. Diabetes care. 2003, p. 3160-3167.

11. Gorissen SHM, Burd NA, Hamer HM, Gijsen AP, Groen BB, van Loon LJC. Carbohydrate coingestion delays dietary protein digestion and absorption but does not modulate postprandial muscle protein accretion. J Clin Endocrinol Metab 99: 2250-2258, 2014.

12. Groen BBL, Horstman AM, Hamer HM, de Haan M, van Kranenburg J, Bierau J, Poeze M, Wodzig WKWH, Rasmussen BB, van Loon LJC. Post-Prandial Protein Handling: You Are What You Just Ate. PLoS ONE 10: e0141582, 2015.

13. Groen BBL, Res PT, Pennings B, Hertle E, Senden JMG, Saris WHM, van Loon LJC. Intragastric protein administration stimulates overnight muscle protein synthesis in elderly men. Am J Physiol Endocrinol Metab 302: E52-60, 2012.

14. Holwerda AM, Kouw IW, Trommelen J, Halson SL, Wodzig WK, Verdijk LB, van Loon LJ. Physical Activity Performed in the Evening Increases the Overnight Muscle Protein Synthetic Response to Presleep Protein Ingestion in Older Men. J Nutr 146: 1307-1314, 2016.

15. Katsanos CS, Kobayashi H, Sheffield-Moore M, Aarsland A, Wolfe RR. Aging is associated with diminished accretion of muscle proteins after the ingestion of a small bolus of essential amino acids. Am J Clin Nutr 82: 1065-1073, 2005.

16. Katsanos CS, Kobayashi H, Sheffield-Moore M, Aarsland A, Wolfe RR. A high proportion of leucine is required for optimal stimulation of the rate of muscle protein synthesis by essential amino acids in the elderly. Am J Physiol Endocrinol Metab 291: E381-7, 2006.

17. Kim IY, Schutzler S, Schrader A, Spencer HJ, Azhar G, Ferrando AA, Wolfe RR. The anabolic response to a meal containing different amounts of protein is not limited by the maximal stimulation of protein synthesis in healthy young adults. Am J Physiol Endocrinol Metab 310: E73-80, 2016.

18. Kim IY, Schutzler S, Schrader A, Spencer H, Kortebein P, Deutz NEP, Wolfe RR, Ferrando AA. Quantity of dietary protein intake, but not pattern of intake, affects net protein balance primarily through differences in protein synthesis in older adults. Am J Physiol Endocrinol Metab 308: E21-E28, 2014. 
19. Mayhew JL, Prinster JL, Ware JS, Zimmer DL, Arabas JR, Bemben MG. Muscular endurance repetitions to predict bench press strength in men of different training levels. J Sports Med Phys Fitness 35: 108113, 1995

20. Mitchell WK, Williams J, Atherton P, Larvin M, Lund J, Narici M. Sarcopenia, dynapenia, and the impact of advancing age on human skeletal muscle size and strength; a quantitative review. Front Physiol 3: 260, 2012.

21. Moore DR, Robinson MJ, Fry JL, Tang JE, Glover El, Wilkinson SB, Prior T, Tarnopolsky MA, Phillips SM. Ingested protein dose response of muscle and albumin protein synthesis after resistance exercise in young men. Am J Clin Nutr 89: 161-168, 2009.

22. Moore DR, Tang JE, Burd NA, Rerecich T, Tarnopolsky MA, Phillips SM. Differential stimulation of myofibrillar and sarcoplasmic protein synthesis with protein ingestion at rest and after resistance exercise. J Physiol 587: 897-904, 2009.

23. Moro T, Brightwell CR, Deer RR, Graber TG, Galvan E, Fry CS, Volpi E, Rasmussen BB. Muscle Protein Anabolic Resistance to Essential Amino Acids Does Not Occur in Healthy Older Adults Before or After Resistance Exercise Training. J Nutr 148: 900-909, 2018.

24. Murton AJ, Marimuthu K, Mallinson JE, Selby AL, Smith K, Rennie MJ, Greenhaff PL. Obesity Appears to Be Associated With Altered Muscle Protein Synthetic and Breakdown Responses to Increased Nutrient Delivery in Older Men, but Not Reduced Muscle Mass or Contractile Function. Diabetes 64: 3160-3171, 2015.

25. Nygren J, Nair KS. Differential regulation of protein dynamics in splanchnic and skeletal muscle beds by insulin and amino acids in healthy human subjects. Diabetes 52: 1377-1385, 2003.

26. Paddon-Jones D, Sheffield-Moore M, Zhang X-J, Volpi E, Wolf SE, Aarsland A, Ferrando AA, Wolfe RR. Amino acid ingestion improves muscle protein synthesis in the young and elderly. Am J Physiol Endocrinol Metab 286: E321-8, 2004.

27. Pennings B, Groen B, de Lange A, Gijsen AP, Zorenc AH, Senden JMG, van Loon LJC. Amino acid absorption and subsequent muscle protein accretion following graded intakes of whey protein in elderly men. Am J Physiol Endocrinol Metab 302: E992-9, 2012.

28. Pennings B, Koopman R, Beelen M, Senden JMG, Saris WHM, van Loon LJC. Exercising before protein intake allows for greater use of dietary protein-derived amino acids for de novo muscle protein synthesis in both young and elderly men. Am J Clin Nutr 93: 322-331, 2011.

29. Phillips SM, Tipton KD, Aarsland A, Wolf SE, Wolfe RR. Mixed muscle protein synthesis and breakdown after resistance exercise in humans. Am J Physiol 273: E99-107, 1997.

30. Reeds PJ, Garlick PJ. Protein and amino acid requirements and the composition of complementary foods. J Nutr 133: 2953S-61S, 2003.

31. Res PT, Groen B, Pennings B, Beelen M, Wallis GA, Gijsen AP, Senden JMG, van Loon LJC. Protein ingestion before sleep improves postexercise overnight recovery. Med Sci Sports Exerc 44: 1560-1569, 2012.

32. Robinson MJ, Burd NA, Breen L, Rerecich T, Yang Y, Hector AJ, Baker SK, Phillips SM. Dosedependent responses of myofibrillar protein synthesis with beef ingestion are enhanced with resistance exercise in middle-aged men. Appl Physiol Nutr Metab 38: 120-125, 2013.

33. van Loon LJC, Boirie Y, Gijsen AP, Fauquant J, de Roos AL, Kies AK, Lemosquet S, Saris WHM Koopman $\mathbf{R}$. The production of intrinsically labeled milk protein provides a functional tool for human nutrition research. J Dairy Sci 92: 4812-4822, 2009.

34. Wall BT, Dirks ML, van Loon LJC. Skeletal muscle atrophy during short-term disuse: implications for agerelated sarcopenia. Ageing Res Rev 12: 898-906, 2013.

35. Wall BT, Gorissen SH, Pennings B, Koopman R, Groen BBL, Verdijk LB, van Loon LJC. Aging Is Accompanied by a Blunted Muscle Protein Synthetic Response to Protein Ingestion. PLOS ONE 10: e0140903, 2015.

36. Walrand S, Short KR, Bigelow ML, Sweatt AJ, Hutson SM, Nair KS. Functional impact of high protein intake on healthy elderly people. Am J Physiol Endocrinol Metab 295: E921-8, 2008.

37. Williams JP, Phillips BE, Smith K, Atherton PJ, Rankin D, Selby AL, Liptrot S, Lund J, Larvin M, Rennie MJ. Effect of tumor burden and subsequent surgical resection on skeletal muscle mass and protein turnover in colorectal cancer patients. Am J Clin Nutr 96: 1064-1070, 2012.

38. Witard OC, Jackman SR, Breen L, Smith K, Selby A, Tipton KD. Myofibrillar muscle protein synthesis rates subsequent to a meal in response to increasing doses of whey protein at rest and after resistance exercise. Am J Clin Nutr 99: 86-95, 2014. 
Dose response to post-exercise dietary protein ingestion

39. Wolfe RR, Chinkes DL. Isotope tracers in metabolic research: principles and practice of kinetic analysis. 2005.

40. Yang Y, Breen L, Burd NA, Hector AJ, Churchward-Venne TA, Josse AR, Tarnopolsky MA, Phillips SM. Resistance exercise enhances myofibrillar protein synthesis with graded intakes of whey protein in older men. Br J Nutr 108: 1780-1788, 2012. 



\section{Chapter 3}

Leucine co-ingestion augments the muscle protein synthetic response to the ingestion of $15 \mathrm{~g}$ protein following resistance exercise in older men

Andrew M. Holwerda, Kevin J.M. Paulussen, Maarten Overkamp, Joy P.B. Goessens, Irene-Fleur Kramer, Will K. W. H. Wodzig, Lex B. Verdijk, Lisette C.P.G.M. de Groot and Luc J.C. van Loon 
Chapter 3

\section{Abstract}

Background Older adults have shown an attenuated post-exercise increase in muscle protein synthesis rates following ingestion of smaller amounts of protein when compared to younger adults. Consequently, it has been suggested that older adults are required to ingest more protein to increase post-exercise muscle protein synthesis rates when compared to younger adults.

Objective We investigated whether co-ingestion of $1.5 \mathrm{~g}$ free leucine with a single, $15 \mathrm{~g}$ bolus of protein further augments the post-prandial muscle protein synthetic response during recovery from resistance-type exercise in older men.

Methods Twenty-four healthy older men (67 $\pm 1 \mathrm{y}$ ) were randomly assigned to ingest $15 \mathrm{~g}$ milk protein concentrate (MPC80) with (15G+LEU; $n=12$ ) or without (15G; $n=12) 1.5 \mathrm{~g}$ free leucine after performing a single bout of resistancetype exercise. Post-prandial protein digestion and amino acid absorption kinetics, whole-body protein metabolism, and post-prandial myofibrillar protein synthesis rates were assessed using primed, continuous infusions with $\mathrm{L}-\left[\right.$ ring $\left.-{ }^{2} \mathrm{H}_{5}\right]$-phenylalanine, $\mathrm{L}-\left[\right.$ ring $\left.-{ }^{2} \mathrm{H}_{2}\right]$-tyrosine and $\mathrm{L}-\left[1-{ }^{13} \mathrm{C}\right]$-leucine combined with the ingestion of intrinsically $\mathrm{L}-\left[1-{ }^{13} \mathrm{C}\right]$-phenylalanine labeled milk protein.

Results A total of $70 \pm 1 \%(10.5 \pm 0.2 \mathrm{~g})$ and $75 \pm 2 \%(11.2 \pm 0.3 \mathrm{~g})$ of the proteinderived amino acids were released in the circulation during the $6 \mathrm{~h}$ postexercise recovery phase in $15 G+L E U$ and $15 G$, respectively $(P<0.05)$. Postexercise myofibrillar protein synthesis rates were $16 \%(0.058 \pm 0.003$ vs 0.049 $\pm 0.002 \% \cdot \mathrm{h}^{-1} ; \mathrm{P}<0.05$; based upon L-[ring- $\left.{ }^{2} \mathrm{H}_{5}\right]$-phenylalanine) and $19 \%$ ( $0.071 \pm 0.003$ vs $0.060 \pm 0.003 \% \cdot h^{-1}, P<0.05$; based upon L-[1- $\left.{ }^{13} \mathrm{C}\right]$-leucine) greater in 15G+LEU when compared with 15G.

Conclusions Leucine co-ingestion further augments the post-exercise muscle protein synthetic response to the ingestion of a single $15 \mathrm{~g}$ bolus of protein in older men. 


\section{Introduction}

The age-related decline in skeletal muscle mass and strength, termed sarcopenia, is accompanied by impairments in functional capacity and an increased risk of developing chronic metabolic diseases (4). Whereas basal muscle protein synthesis and breakdown rates appear to be unaffected by age (27), the muscle protein synthetic response to the main anabolic stimuli, namely food intake and physical activity, seem to be blunted in older individuals (41). This anabolic resistance is now considered as a central factor contributing to the progression of sarcopenia.

A single session of resistance-type exercise strongly increases muscle protein synthesis rates (30) and therefore represents an effective strategy to compensate for anabolic resistance. For older individuals, ingestion of more than $20 \mathrm{~g}$ protein is required to augment postexercise muscle protein synthesis rates $(10,30,47)$. Older individuals possess the capacity to further increase the post-exercise muscle protein synthetic response by ingesting larger protein doses, with ingestion of $40 \mathrm{~g}$ protein further enhancing the muscle protein synthetic response $(47,48)$. However, older individuals seldom consume $40 \mathrm{~g}$ protein in a single meal $(34,35)$. Therefore, data are warranted to determine nutritional strategies that can augment the muscle protein synthetic response to ingestion of small(er) amounts of protein during recovery from resistance-type exercise in older adults.

Leucine has been established as one of the most anabolic amino acids due to its ability to phosphorylate key anabolic signaling proteins (i.e., mTORC1 and S6K) in skeletal muscle tissue $(3,13)$. Previous work has demonstrated that co-ingestion of free leucine augments the muscle protein synthetic response to protein or amino acid ingestion in older individuals at rest $(7,9,42)$ and after a bout of resistance-type exercise $(2,7,9)$. More recently, it was demonstrated that leucine co-ingested with the main meals augments the integrated anabolic response to resistance-type exercise over multiple days (24). What remains unclear, however, is the effect of free leucine co-ingestion on post-prandial protein handling of the ingestion of a small amount of protein during post-exercise recovery in older individuals. Therefore, in the present study we assessed post-prandial protein handling and the muscle protein synthetic response to the ingestion of a single $15 \mathrm{~g}$ bolus of protein with or without additional free leucine $(1.5 \mathrm{~g})$ during recovery from a single bout of resistance-type exercise in older individuals.

We hypothesized that co-ingestion of $1.5 \mathrm{~g}$ free leucine with a single bolus of $15 \mathrm{~g}$ protein further increases post-exercise muscle protein synthesis rates when compared to the ingestion of $15 \mathrm{~g}$ protein. To test our hypothesis, we selected 24 healthy older (67 $\pm 1 \mathrm{y}$ ) men who ingested $15 \mathrm{~g}$ protein with or without $1.5 \mathrm{~g}$ free leucine during recovery from a single bout of resistance-type exercise. By combining the ingestion of specifically produced intrinsically $\mathrm{L}-\left[1-{ }^{13} \mathrm{C}\right]$-phenylalanine and $\mathrm{L}-\left[1-{ }^{13} \mathrm{C}\right]$-leucine labeled milk protein concentrate with the administration of primed continuous infusions of L-[ring $\left.{ }^{2} \mathrm{H}_{5}\right]$-phenylalanine, L-[1$\left.{ }^{13} \mathrm{C}\right]$-leucine and $\mathrm{L}-\left[\right.$ ring- $-{ }^{2} \mathrm{H}_{2}$ ]-tyrosine, we were able to assess protein digestion and amino 
Chapter 3

acid absorption kinetics, the stimulation of post-exercise muscle protein synthesis rates and the post-prandial incorporation of dietary protein-derived amino acids during recovery from exercise in older individuals. 


\section{Materials and methods}

\section{Subjects}

A total of 24 healthy, normoglycemic, older men ( $67 \pm 1 \mathrm{y})$ were selected to participate in the present study. Subjects' characteristics of the study participants are presented in Table 3.1. Subjects were randomly assigned to ingest either $15 \mathrm{~g}$ protein (15G: $n=12$ ) or $15 \mathrm{~g}$ protein with $1.5 \mathrm{~g}$ crystalline free leucine ( $15 \mathrm{G}+\mathrm{LEU}: n=12$ ) after completing a single bout of wholebody resistance-type exercise. All subjects were informed of the nature and possible risks of the experimental procedures before their written informed consent was obtained. The study was approved by the Medical Ethical Committee of the Maastricht University Medical Centre, The Netherlands, and conformed to standards for the use of human subjects in research as outlined in the most recent version of the Helsinki Declaration. This study is part of a greater project, which was registered at the Netherlands Trial Registry as NTR4492. Data from the 15G group have been previously published as part of a protein dose-response study conducted in older men (Chapter 2).

Table 3.1 Subjects' $^{\prime}$ characteristics ${ }^{1}$

\begin{tabular}{|c|c|c|c|}
\hline & $15 G(n=12)$ & $15 G+\operatorname{LEU}(n=12)$ & $P$ \\
\hline Age, y & $69 \pm 2$ & $66 \pm 2$ & 0.45 \\
\hline Total body mass, kg & $78.8 \pm 3.2$ & $79.0 \pm 2.4$ & 0.96 \\
\hline Total lean mass, kg & $57.6 \pm 2.3$ & $58.1 \pm 1.5$ & 0.86 \\
\hline Appendicular lean mass, $\mathrm{kg}$ & $24.9 \pm 1.1$ & $25.6 \pm 0.7$ & 0.64 \\
\hline Percentage body fat, $\%$ & $23.9 \pm 0.9$ & $23.2 \pm 1.2$ & 0.62 \\
\hline Height, m & $1.75 \pm 0.02$ & $1.78 \pm 0.01$ & 0.23 \\
\hline $\mathrm{BMI}, \mathrm{kg} \cdot \mathrm{m}^{-2}$ & $25.8 \pm 0.8$ & $24.9 \pm 0.8$ & 0.43 \\
\hline $\mathrm{HbA} 1 \mathrm{c}, \%$ & $5.3 \pm 0.1$ & $5.3 \pm 0.1$ & 0.80 \\
\hline Resting glucose, $\mathrm{mmol} \cdot \mathrm{L}^{-1}$ & $5.8 \pm 0.2$ & $6.2 \pm 0.2$ & 0.13 \\
\hline Resting insulin, $\mathrm{mU} \cdot \mathrm{L}^{-1}$ & $9.3 \pm 0.9$ & $8.4 \pm 1.2$ & 0.59 \\
\hline HOMA-IR & $2.4 \pm 0.2$ & $2.4 \pm 0.4$ & 1.00 \\
\hline MVPA, min & $145 \pm 31$ & $160 \pm 33$ & 0.95 \\
\hline 1RM - Leg press, kg & $179 \pm 8$ & $166 \pm 6$ & 0.23 \\
\hline 1RM - Leg extension, kg & $86 \pm 6$ & $88 \pm 2$ & 0.79 \\
\hline 1RM - Lat pulldown, kg & $60 \pm 4$ & $62 \pm 4$ & 0.78 \\
\hline $1 \mathrm{RM}$ - Chest press, kg & $60 \pm 6$ & $58 \pm 5$ & 0.77 \\
\hline
\end{tabular}

${ }^{1}$ Values are mean \pm SEM. $n=12$ per treatment group. 15G: $15 \mathrm{~g}$ dietary protein, 15G+LEU: $15 \mathrm{~g}$ dietary protein + $1.5 \mathrm{~g}$ crystalline leucine. 1RM: one repetition maximum, HbA1c: glycosylated hemoglobin, MVPA: moderateto-vigorous physical activity, Resting: resting and fasted values. Data were analyzed with a student's unpaired ttest. No differences were detected between groups. 


\section{Pretesting}

Participants arrived at the laboratory at $0830 \mathrm{~h}$ by car or public transport in an overnight fasted state. Upon arrival, body weight, body composition, and bone mineral content were measured with DEXA (Dual-energy X-ray absorptiometry, DEXA; Discovery A; Hologic, Bedford, MA). Thereafter, all participants performed an oral glucose tolerance test (OGTT). Plasma glucose and insulin concentrations were measured to determine oral glucose intolerance and/or the presence of type 2 diabetes according to 2006 American Diabetes Association guidelines (1). All subjects were screened on medical issues and excluded if any gastrointestinal, neurological or renal diseases were present.

Subjects were cleared to perform resistance-type exercise by a cardiologist who examined electrocardiograms (ECG) measured at rest and during submaximal cycling (performed at 70 $\%$ of age-predicted heartrate max). The subjects were then familiarized with the exercise equipment and physical activity protocol. Subjects first performed a 10-min cycling warm-up at $70 \%$ of their age-predicted heart rate max before completing an estimation of their $1 \mathrm{RM}$ (one repetition maximum) on the leg press and leg extension exercises using the multiple repetitions testing procedure (22). For each exercise, subjects performed 10 submaximal repetitions to warm-up and become familiarized with the equipment and to have lifting technique critiqued and corrected. Subjects then performed sets at progressively increasing loads until failing to complete a valid repetition, judged by their inability to complete the full range of motion for an exercise. Ideally, subjects failed within 3-6 repetitions during the last and heaviest set. A 2-min resting period between subsequent attempts was allowed. The pretesting and experimental trials were separated by a period of at least 7 days.

\section{Diet and physical activity}

All volunteers were instructed to refrain from any exhaustive physical activity and to keep their diet as consistent as possible $72 \mathrm{~h}$ prior to the trial. Subjects filled in dietary records for $48 \mathrm{~h}$ immediately before the experimental trial. Subjects consumed $8.6 \pm 0.5 \mathrm{MJ}^{- \text {day }^{-1} \text { on }}$ average, with $47 \pm 1$ energy\% (En\%) as carbohydrate, $33 \pm 1 \mathrm{En} \%$ as fat, and $18 \pm 1 \mathrm{En} \%$ as protein. Dietary protein intake averaged $1.1 \pm 0.1 \mathrm{~g}^{\mathrm{kg}} \mathrm{g}^{-1}$ bodyweight. On the evening before the experiment, all subjects consumed a standardized meal $\left(22.0 \pm 0.6 \mathrm{~kJ} \cdot \mathrm{kg}^{-1}\right.$ bodyweight, consisting of $55 \mathrm{En} \%$ as carbohydrate, $20 \mathrm{En} \%$ as protein, and $25 \mathrm{En} \%$ as fat).

\section{Experimental Protocol}

At $0800 \mathrm{~h}$, participants reported to the lab in a fasted and rested state and had Teflon catheters inserted into the antecubital veins of one arm and the top of the opposite hand. At $0830 \mathrm{~h}$ ( $t=-150 \mathrm{~min}$ ), a background blood sample was taken prior to the initiation of the tracer infusion protocol. The plasma and intracellular phenylalanine and leucine pools were primed with a single, intravenous dose (priming dose) of L-[ring $\left.{ }^{2} \mathrm{H}_{5}\right]$-phenylalanine (3.6 
$\left.\mu \mathrm{mol} \cdot \mathrm{kg}^{-1}\right), \mathrm{L}-\left[\right.$ ring $\left.^{-}{ }^{2} \mathrm{H}_{2}\right]$-tyrosine $\left(1.10 \mu \mathrm{mol} \cdot \mathrm{kg}^{-1}\right), \mathrm{L}-\left[1-{ }^{13} \mathrm{C}\right]$-leucine $\left(7.19 \mu \mathrm{mol} \cdot \mathrm{kg}^{-1}\right)$. Once primed, the continuous stable isotope infusion was initiated (infusion rate: $0.06 \mu \mathrm{mol} \cdot \mathrm{kg}$ ${ }^{1} \cdot \mathrm{min}^{-1} \mathrm{~L}$-[ring- $\left.{ }^{2} \mathrm{H}_{5}\right]$-phenylalanine, $0.018 \mu \mathrm{mol} \cdot \mathrm{kg}^{-1} \cdot \mathrm{min}^{-1} \mathrm{~L}$-[ ring- $\left.{ }^{2} \mathrm{H}_{2}\right]$-tyrosine, $0.12 \mu \mathrm{mol} \cdot \mathrm{kg}^{-}$ ${ }^{1} \cdot \mathrm{min}^{-1} \mathrm{~L}-\left[1-{ }^{13} \mathrm{C}\right]$-leucine; Cambridge Isotopes Laboratories, Andover, MA). Participants rested for $1.5 \mathrm{~h}$ until $1000 \mathrm{~h}(t=-60 \mathrm{~min})$, when the participants completed the resistance-type exercise session. At $1100 \mathrm{~h}(t=0 \mathrm{~min})$, immediately after the resistance-type exercise session, subjects had a blood sample and muscle biopsy collected from a randomized leg. Subsequently, subjects ingested a $500 \mathrm{~mL}$ beverage containing $15 \mathrm{~g}$ intrinsically L-[1- $\left.{ }^{13} \mathrm{C}\right]-$ phenylalanine and L-[1-13 C]-leucine labeled milk protein (MPC80) alone (15G) or with $(15 \mathrm{G}+\mathrm{LEU})$ an added $1.5 \mathrm{~g}$ of crystalline free leucine. The beverages contained $1.5 \mathrm{~mL}$ vanilla extract to improve palatability (Dr. Oetker, Amersfoort, the Netherlands). Blood samples (10 $\mathrm{mL}$ ) were subsequently taken at $t=30,60,90,120,180,240,300,360 \mathrm{~min}$ after protein ingestion. A second muscle biopsy was obtained from the contralateral leg at $1700 \mathrm{~h}(t=$ $360 \mathrm{~min})$, signifying the end of the experimental trial.

Blood samples were collected in EDTA containing tubes and centrifuged at $1000 \mathrm{~g}$ for 10 min at $4{ }^{\circ} \mathrm{C}$. Aliquots of plasma were frozen in liquid nitrogen and stored at $-80^{\circ} \mathrm{C}$. Muscle biopsies were obtained from the middle region of the $M$. vastus lateralis, $15 \mathrm{~cm}$ above the patella and approximately $4 \mathrm{~cm}$ below entry through the fascia, using the percutaneous needle biopsy technique (5). Muscle samples were dissected carefully and freed from any visible non-muscle material. The muscle samples were immediately frozen in liquid nitrogen and stored at $-80^{\circ} \mathrm{C}$ until further analysis.

\section{Resistance-type exercise protocol}

The exercise protocol consisted of $60 \mathrm{~min}$ of moderate-to-high intensity whole-body resistance-type exercise. After 10 min of self-paced cycling at $100 \mathrm{~W}$ with a cadence of 60 80 RPM, subjects performed 5 sets of 10 repetitions on the horizontal leg press machine (Technogym BV, Rotterdam, Netherlands), 2 sets of 10 repetitions on the lat pull down machine (Technogym BV), 2 sets of 10 repetitions on the chest press machine and 5 sets of 10 repetitions on the leg extension machine (Technogym BV). The first set of the lower body exercises were performed at $50 \% 1 \mathrm{RM}$ and sets $2-5$ were performed at 75-80 \% 1RM. All sets on the upper body exercises were performed at 75-80 \% 1RM. Subjects were allowed to rest for 2 min between all sets.

\section{Preparation of tracer and production of intrinsically-labeled protein}

The stable isotope tracers $\mathrm{L}-\left[\operatorname{ring}_{-}{ }^{2} \mathrm{H}_{5}\right]$-phenylalanine, $\mathrm{L}-\left[1-{ }^{13} \mathrm{C}\right]$-leucine and $\mathrm{L}-\left[\right.$ ring $\left.^{-}{ }^{2} \mathrm{H}_{2}\right]-$ tyrosine were purchased from Cambridge Isotopes (Andover, MA) and dissolved in $0.9 \%$ saline before infusion (Basic Pharma, Geleen, the Netherlands). Continuous intravenous infusions were performed using a calibrated IVAC 598 pump (San Diego, CA, USA). 
Intrinsically L-[1 $\left.-{ }^{13} \mathrm{C}\right]-$ phenylalanine and L- $\left[1-{ }^{13} \mathrm{C}\right]$-leucine labeled milk protein (MPC80) was extracted from whole milk obtained during the constant infusion of $\mathrm{L}-\left[1-{ }^{13} \mathrm{C}\right]$-phenylalanine $\left(455 \mu \mathrm{mol} \cdot \mathrm{min}^{-1}\right)$ and $\mathrm{L}-\left[1-{ }^{13} \mathrm{C}\right]$-leucine $\left(200 \mu \mathrm{mol} \cdot \mathrm{min}^{-1}\right)$ for $96 \mathrm{~h}$ in a lactating dairy cow $(8$, 38). The milk was collected, processed, and fractionated into the MPC 80 similarly to what has been previously described $(15,31,38)$. The $\mathrm{L}-\left[1-{ }^{13} \mathrm{C}\right]$-phenylalanine and L- $\left[1-{ }^{13} \mathrm{C}\right]$-leucine enrichments in MPC80 were measured by gas chromatography-combustion-isotope ratio mass spectrometry (GC-C-IRMS; MAT 252, Finnigan, Breman, Germany) and averaged 38.3 mole percent excess (MPE) and 10.8 MPE, respectively. The proteins met all chemical and bacteriological specifications for human consumption.

Plasma and muscle analysis

Plasma glucose and insulin concentrations were analyzed using commercially available kits (GLUC3, Roche, Ref: 05168791 190, and Immunologic, Roche, Ref: 12017547 122, respectively). Plasma amino acid concentrations and enrichments were determined by gas chromatography-mass spectrometry analysis (GC-MS; Agilent 7890A GC/5975C; MSD, Wilmington, Delaware, USA). Myofibrillar protein-bound L-[ring- $\left.{ }^{2} \mathrm{H}_{5}\right]$-phenylalanine enrichments were determined by GC-MS analysis, whereas the $\mathrm{L}-\left[1-{ }^{13} \mathrm{C}\right]$-phenylalanine and $\mathrm{L}-\left[1-{ }^{13} \mathrm{C}\right]$-leucine enrichments were determined by GC-C-isotope ratio mass spectrometer analysis (GC-C-IRMS; Trace GC Ultra, IRMS model MAT 253; Thermo Scientific). For complete details, see the Materials and methods section in Chapter 2.

\section{Western blotting}

Muscle was homogenized as previously described (40), $10 \mu \mathrm{L}$ of protein was loaded and standard SDS-PAGE procedures were followed. Antibodies included total and phosphorylated mTOR (Ser $\left.{ }^{2448}\right)$, S6 protein kinase 1 (S6K1; Thr $\left.{ }^{389}\right)$, RS6 $\left(\mathrm{Ser}^{235} / \mathrm{Ser}^{236}\right)$, anti-phospho-eukaryotic translation initiation factor 4E-binding protein-1 (4E-BP1; $\mathrm{Thr}^{37 / 46}$ ), anti-mTOR, anti-S6K1, anti-ribosomal protein S6 (RS6), and anti-4E-BP1, which were purchased from Cell Signaling Technology (Danvers, MA). $\alpha$-tubulin (Abcam) was used as a loading control. All samples for a given protein were detected on the same membrane using chemiluminescence and the FluorChem HD imaging system (Alpha Innotech, Santa Clara, CA, USA).

\section{Calculations}

Ingestion of L- $\left[1-{ }^{13} \mathrm{C}\right]$-phenylalanine labeled protein, intravenous infusion of L-[ring- $\left.{ }^{2} \mathrm{H}_{5}\right]$ phenylalanine, and blood sample enrichment values were used to assess whole-body amino acid kinetics in non-steady state conditions. Total, exogenous, and endogenous phenylalanine rates of appearance $\left(R_{\mathrm{a}}\right)$ and plasma availability of dietary protein-derived 
phenylalanine that appeared in the systemic circulation as a fraction of total amount of phenylalanine that was ingested, (Phe plasma ) were calculated using modified Steele's equations $(6,11,46)$. Myofibrillar protein fractional synthetic rate (FSR) was calculated using the standard precursor-product method. For complete details, see the Materials and methods section in Chapter 2.

\section{Statistics}

All data are expressed as mean+SEM. Baseline characteristics between groups were compared using a student's unpaired t-test. A two-factor repeated measures ANOVA (time $x$ treatment) with time as within-subjects factor and treatment group as between-subjects factor was performed for the analysis of plasma amino acid concentrations, plasma tracer enrichments, whole-body kinetics and glucose and insulin concentrations. The analysis was carried out for the period starting at the time of protein administration, between $t=0$ and $360 \mathrm{~min}$. Upon identification of a significant time $\mathrm{x}$ treatment interaction, Tukey post hoc testing was used to identify time points in which the treatments differed. Non timedependent variables (i.e., Whole-body metabolism, FSR values, L- $\left[1-{ }^{13} \mathrm{C}\right]$-phenylalanine myofibrillar enrichments) were compared between treatment groups using Student's unpaired $t$-tests. Statistical significance was set at $P<0.05$. All calculations were performed using SPSS 21.0 (IBM, Chicago, Illinois, USA). 
Chapter 3

\section{Results}

Plasma concentrations

Plasma glucose (Figure 3.2A) and insulin (Figure 3.2B) concentrations after protein ingestion did not differ between the PRO and PRO+EX groups $(P>0.05)$. Plasma insulin concentrations increased after protein ingestion in both treatments, reaching peak levels 30 min after protein ingestion.

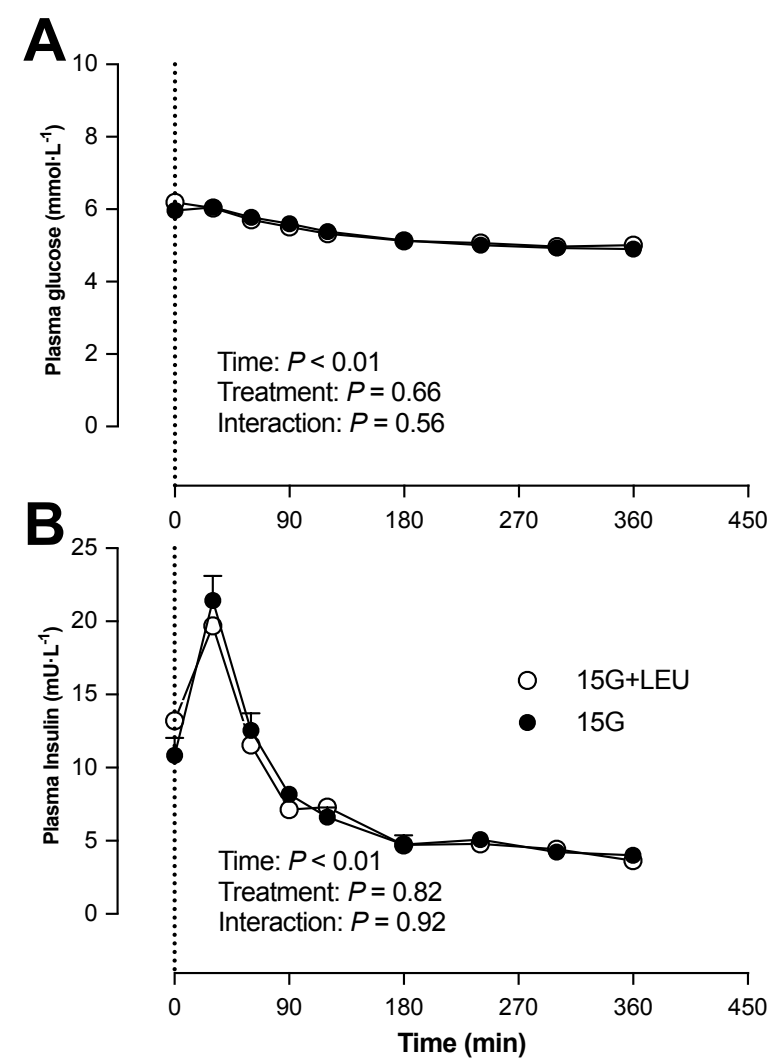

Figure 3.2 Plasma glucose $\left(A, \mathrm{mmol} \cdot \mathrm{L}^{-1}\right)$ and insulin concentrations $\left(B, \mathrm{mU} \cdot \mathrm{L}^{-1}\right)$ following ingestion of $15 \mathrm{~g}$ milk protein (15G; $n=12)$ or $15 \mathrm{~g}$ milk protein with $1.5 \mathrm{~g}$ free leucine $(15 \mathrm{G}+\mathrm{LEU} ; \mathrm{n}=12)$ after resistance-type exercise in older men. The dotted line represents the ingestion of the beverage. Values represent means + SEM. Data were analyzed with repeated measures (time $x$ treatment group) ANOVA. A; time effect: $P<0.01$, treatment effect: $P>0.05$, time $x$ treatment group: $P>0.05$. B; time effect: $P<0.01$, treatment effect: $P>0.05$, time $x$ treatment group: $P>0.05$.

Plasma leucine concentrations (Figure 3.3A) increased rapidly following protein ingestion ( $P$ $<0.01$ ), but were greater in 15G+LEU (peak values: $407 \pm 23 \mu \mathrm{mol} \cdot \mathrm{L}^{-1}$ ) when compared to $15 \mathrm{G}$ (peak values: $234 \pm 16 \mu \mathrm{mol} \cdot \mathrm{L}^{-1}$, respectively, $P<0.01$ ). Area under the curve (AUC) analysis revealed that plasma leucine availability over the $6 \mathrm{~h}$ post-prandial was approximately 1.8 -fold greater in the $15 \mathrm{G}+\mathrm{LEU}$ group when compared to the $15 \mathrm{G}$ group ( $P$ $<0.001$ ). Plasma phenylalanine concentrations (Figure 3.3C) increased rapidly following 
protein ingestion $(P<0.01)$, but did not differ between groups $(P>0.05)$. Plasma tyrosine concentrations (Figure 3.3D) increased following protein ingestion $(P<0.01)$ but did not differ between groups $(P>0.05)$.

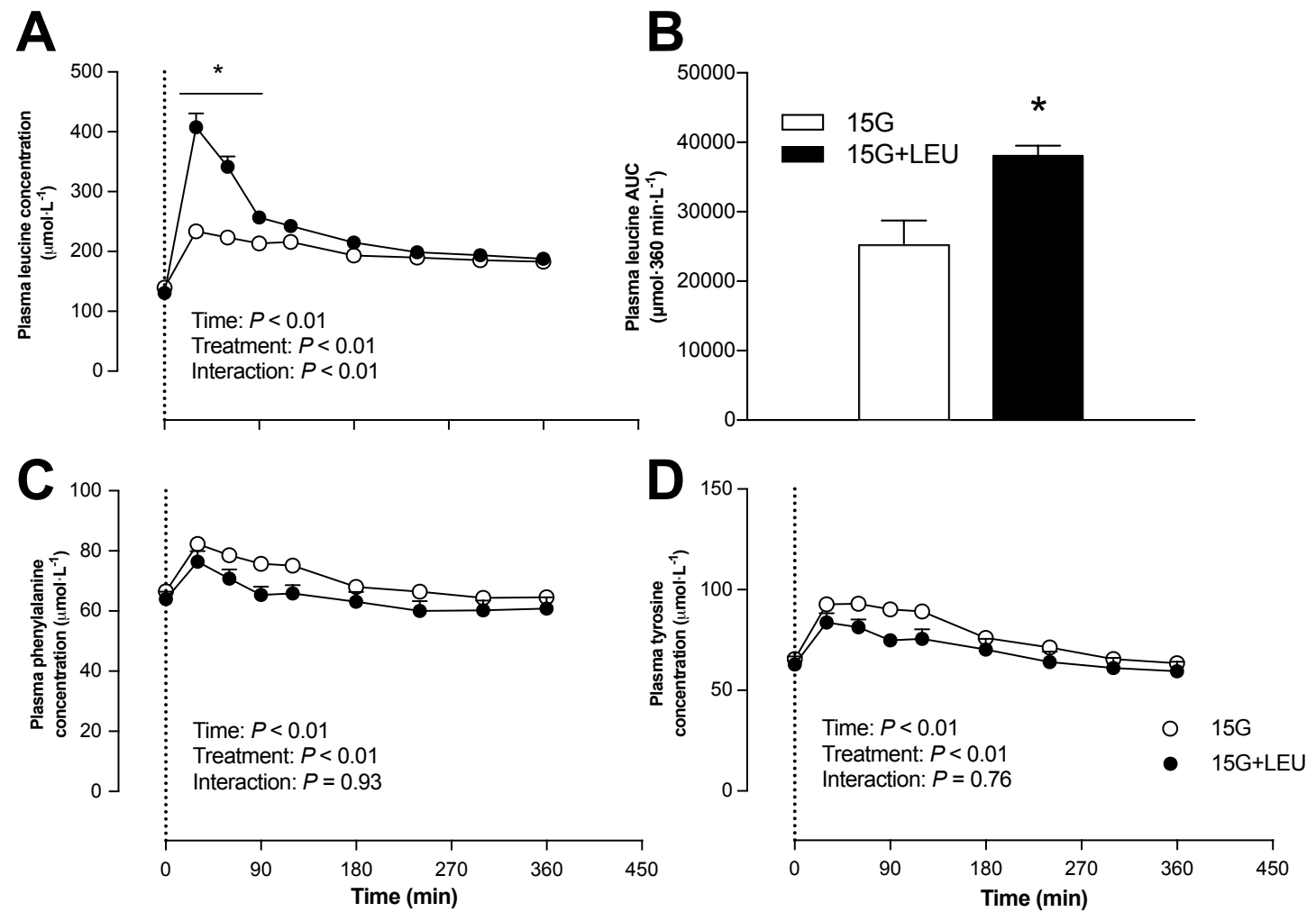

Figure 3.3 Plasma leucine (A), phenylalanine (B) and tyrosine $(C)$ concentrations $\left(\mu \mathrm{mol} \cdot \mathrm{L}^{-1}\right)$ following ingestion of $15 \mathrm{~g}$ milk protein (15G; $n=12)$ or $15 \mathrm{~g}$ milk protein with $1.5 \mathrm{~g}$ free leucine $(15 \mathrm{G}+L E U ; n=12)$ after resistancetype exercise in older men. The dotted line represents the ingestion of the beverage. Values represent means + SEM. Data were analyzed with repeated measures (time $x$ treatment group) ANOVA. $A$; time $x$ treatment group: $P<0.01$. $B$; time $x$ treatment group: $P>0.05$. $C$; time $x$ treatment group: $P>0.05$. Plasma leucine area under the curve over $360 \mathrm{~min}\left(B, \mu \mathrm{mol} \cdot 360 \mathrm{~min} \cdot \mathrm{L}^{-1}\right)$ and analyzed with a student's unpaired t-test. ${ }^{*}$ Significant difference $(P<0.05)$ from $15 G$.

\section{Plasma amino acid enrichments}

Plasma enrichments from ingested (L-[1- $\left.{ }^{13} \mathrm{C}\right]-$ phenylalanine), infused (L-[ring- $\left.{ }^{2} \mathrm{H}_{5}\right]-$ phenylalanine) and ingested and infused (L- $\left[1-{ }^{13} \mathrm{C}\right]$-leucine) amino acid tracers did not differ between treatments before protein ingestion ( $t=0 \mathrm{~min} ; P>0.05$ ). After protein ingestion, plasma L- $\left[1-{ }^{13} \mathrm{C}\right]$-phenylalanine enrichments, originating from the ingested protein, increased in both groups reaching peak values at $t=60 \mathrm{~min}$ in $15 \mathrm{G}(9.6 \pm 0.5 \mathrm{MPE})$ and $t=120 \mathrm{~min}$ in $15 \mathrm{G}+\mathrm{LEU}(8.7 \pm 0.5 \mathrm{MPE})$ in $15 \mathrm{G}+\mathrm{LEU}$. Plasma L- $\left[\right.$ ring $\left.^{2}{ }^{2} \mathrm{H}_{5}\right]$-phenylalanine enrichments decreased after protein ingestion in both groups $(P<0.001)$, but no significant group effect was detected $(P>0.05)$. Plasma $L-\left[1-{ }^{13} \mathrm{C}\right]$-leucine enrichments increased after protein ingestion $(P<0.001)$, but no significant group effect was detected $(P>0.05)$. 


\section{Whole-body amino acid kinetics}

Exogenous phenylalanine appearance rates (Figure 3.4A) increased following protein ingestion with peak levels being reached at $t=60 \mathrm{~min}$ in both treatment groups (15G: 0.19 $\pm 0.01,15 \mathrm{G}+\mathrm{LEU}: 0.16 \pm 0.02 \mu \mathrm{mol} \mathrm{Phe}^{\mathrm{kg}} \mathrm{kg}^{-1} \cdot \mathrm{min}^{-1} ; P>0.05$ ). Dietary protein-derived amino acid availability, calculated as a fraction of the total amount of ingested protein (Figure 3.4B), was higher in $15 \mathrm{G}(75 \pm 2 \%)$ when compared to $15 \mathrm{G}+\mathrm{LEU}(70 \pm 1 \% ; P<0.05)$.

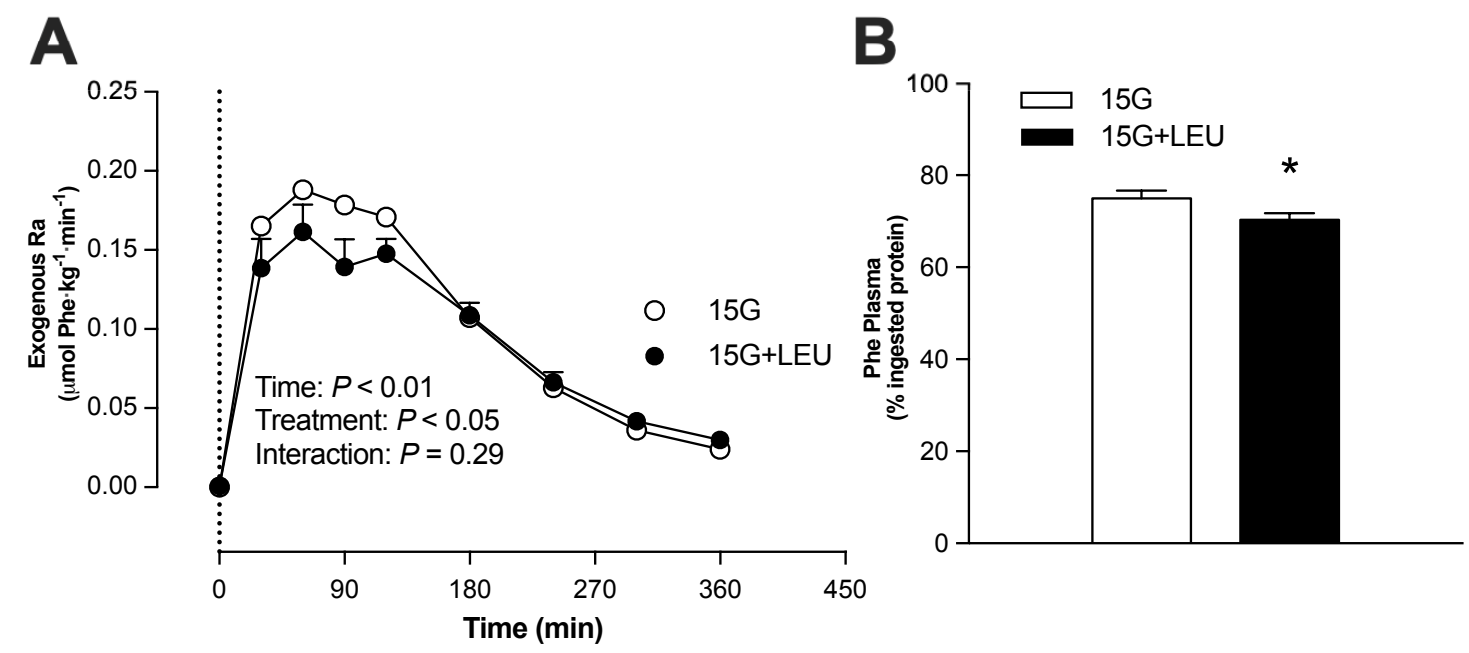

Figure 3.4 Exogenous phenylalanine rate of appearance ( $A, R a)$ expressed in $\mu \mathrm{mol} \cdot$ phenylalanine $\cdot \mathrm{kg}^{-1} \cdot \mathrm{min}^{-1}$ following ingestion of $15 \mathrm{~g}$ milk protein $(15 \mathrm{G} ; \mathrm{n}=12)$ or $15 \mathrm{~g}$ milk protein with $1.5 \mathrm{~g}$ free leucine $(15 \mathrm{G}+\mathrm{LEU} ; \mathrm{n}$ $=12$ ) after resistance-type exercise in older men. The dotted line represents the ingestion of the beverage. Values represent means + SEM. Data were analyzed with repeated measures (time $x$ treatment group) ANOVA. Time $x$ treatment group: $P<0.01$. C; time $x$ treatment group: $P<0.01$. Dietary protein-derived amino acid plasma availability $(B)$, calculated as a fraction of the total amount of ingested protein (\% ingested protein). *Significantly different $(P<0.05)$ from $15 G+L E U$.

Whole-body protein synthesis rates did not differ between the treatment groups (15G: 0.60 $\left.\pm 0.01,15 \mathrm{G}+\mathrm{LEU}: 0.59 \pm 0.01 \mu \mathrm{mol} \mathrm{Phe} \cdot \mathrm{kg}^{-1} \cdot \mathrm{min}^{-1} ; P>0.05\right)$. Whole-body protein breakdown rates did not differ between the treatment groups (15G: $0.49 \pm 0.01,15 \mathrm{G}+\mathrm{LEU}: 0.49 \pm 0.01$ $\mu \mathrm{mol} P$ Phe $\left.\cdot \mathrm{kg}^{-1} \cdot \mathrm{min}^{-1} ; P>0.05\right)$. Protein ingestion resulted in a positive whole-body protein net balance, with no differences observed between the treatment groups (15G: $0.108 \pm$ $\left.0.004,15 \mathrm{G}+\mathrm{LEU}: 0.105 \pm 0.003 \mu \mathrm{mol} \mathrm{Phe} \cdot \mathrm{kg}^{-1} \cdot \mathrm{min}^{-1} ; P>0.05\right)$. Furthermore, leucine coingestion did not appear to influence whole-body phenylalanine oxidation rates (15G: 0.049 $\left.\pm 0.003,15 \mathrm{G}+\mathrm{LEU}: 0.046 \pm 0.002 \mu \mathrm{mol} \mathrm{Phe} \cdot \mathrm{kg}^{-1} \cdot \mathrm{min}^{-1} ; \mathrm{P}>0.05\right)$. 


\section{Myofibrillar fractional synthesis rates and protein-bound enrichments}

Myofibrillar L- $\left[1-{ }^{13} \mathrm{C}\right]$-leucine and L-[ring- $\left.{ }^{2} \mathrm{H}_{5}\right]$-phenylalanine enrichments were measured in muscle samples collected immediately before protein ingestion and after the $6 \mathrm{~h}$ postprandial period. The post-prandial increase in myofibrillar protein bound L-[1- $\left.{ }^{13} \mathrm{C}\right]$-leucine enrichments tended to be greater in 15G+LEU when compared to $15 \mathrm{G}(0.0360 \pm 0.0016$ vs $0.0314 \pm 0.0016 \mathrm{MPE}$, respectively; $P=0.055)$. The post-prandial increase in myofibrillar protein bound $\mathrm{L}-\left[\right.$ ring- $\left.^{2} \mathrm{H}_{5}\right]$-phenylalanine enrichment was greater in $15 \mathrm{G}+\mathrm{LEU}$ when compared to $15 \mathrm{G}(0.0330 \pm 0.0015$ vs $0.0278 \pm 0.0011 \mathrm{MPE}$, respectively; $P<0.05)$.

Myofibrillar protein FSR (in \%.h ${ }^{-1}$ ) was calculated using L-[ring $\left.-{ }^{2} \mathrm{H}_{5}\right]$-phenylalanine (Figure 3.5A) plasma and muscle protein-bound enrichments and using $\mathrm{L}-\left[1-{ }^{13} \mathrm{C}\right]$-leucine (Figure 3.5B) plasma and muscle protein-bound enrichments. When FSR was calculated using L[ring- ${ }^{2} \mathrm{H}_{5}$ ]-phenylalanine, myofibrillar protein FSR was approximately $16 \%$ greater in $15 G+$ LEU $\left(0.0575 \pm 0.0032 \% \cdot h^{-1}\right)$ when compared with $15 G\left(0.0495 \pm 0.0021 \% \cdot h^{-1} ; P<\right.$ 0.05). When FSR was calculated using $\mathrm{L}-\left[1-{ }^{13} \mathrm{C}\right]$-leucine, myofibrillar protein FSR was approximately $19 \%$ greater in $15 \mathrm{G}+\mathrm{LEU}\left(0.0710 \pm 0.0048 \% \cdot \mathrm{h}^{-1}\right)$ when compared with $15 \mathrm{G}$ $\left(0.0598 \pm 0.0030 \% \cdot \mathrm{h}^{-1} ; P<0.05\right) . \mathrm{L}-\left[1-{ }^{13} \mathrm{C}\right]$-phenylalanine myofibrillar protein-bound enrichments (Figure 3.6) were not different in 15G+LEU (0.0205 $\pm 0.0022 \mathrm{MPE})$ when compared with $15 \mathrm{G}(0.0171 \pm 0.0017 \mathrm{MPE} ; P=0.24)$.

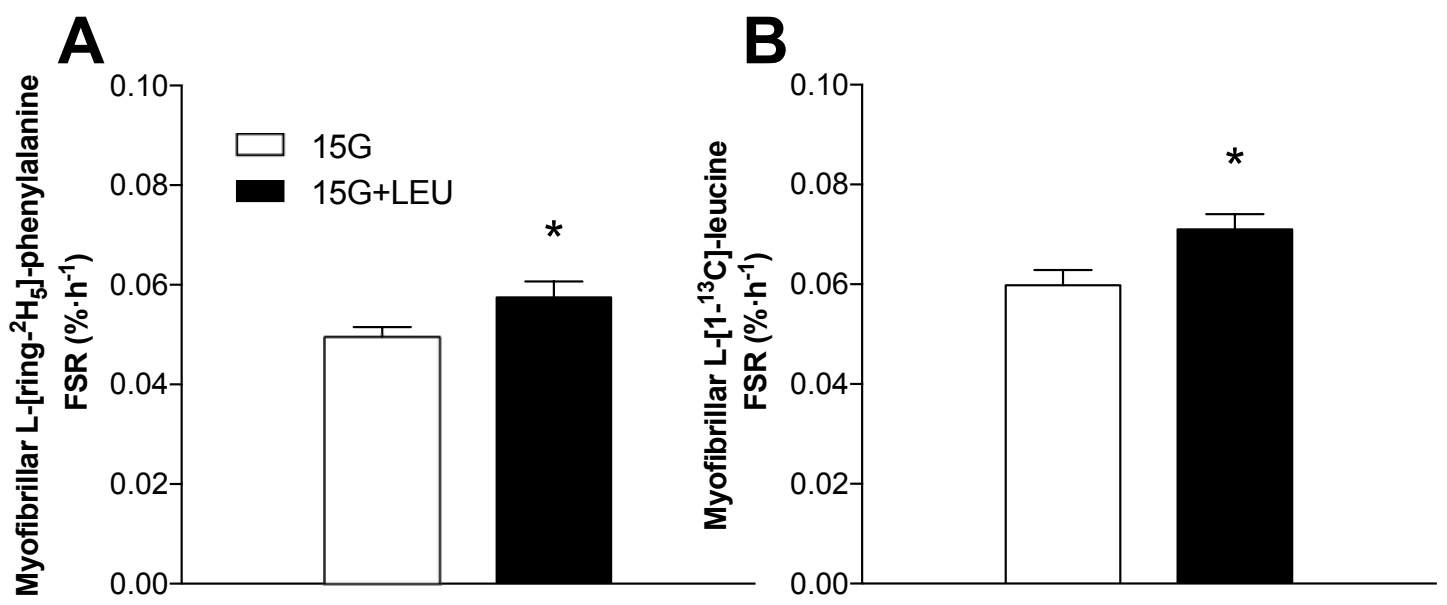

Figure 3.5 Myofibrillar protein fractional synthetic rates (FSR in $\% \cdot h^{-1}$ ) assessed using $L-\left[r i n g-{ }^{2} H_{5}\right]$-phenylalanine (A) and $L-\left[1-{ }^{13} \mathrm{C}\right]$-leucine $(B)$ and following ingestion of $15 \mathrm{~g}$ milk protein $(15 \mathrm{G} ; n=12)$ or $15 \mathrm{~g}$ milk protein with $1.5 \mathrm{~g}$ free leucine $(15 \mathrm{G}+\mathrm{LEU} ; n=12)$ after resistance-type exercise in older men. Values represent means + SEM. Data were analyzed with a student's unpaired t-test. *Significantly different $(P<0.05)$ from $15 G$. 
Chapter 3

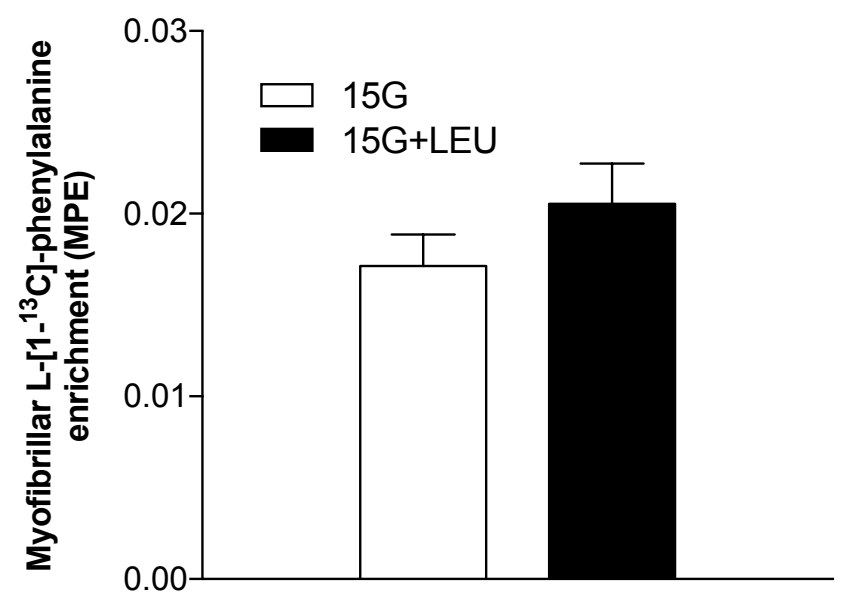

Figure 3.6 $\mathrm{L}-\left[1-{ }^{13} \mathrm{C}\right]-$ phenylalanıne incorporatıon into myotıbrillar proteın tollowing ingestion of $15 \mathrm{~g}$ milk protein (15G; $n=12)$ or $15 \mathrm{~g}$ milk protein with $1.5 \mathrm{~g}$ free leucine $(15 \mathrm{G}+L E U ; n=12)$ after resistance-type exercise in older men. No significant differences between groups $(P=0.24)$. Values represent means $+S E M$. Data were analyzed with student's unpaired t-test.

\section{Cellular signaling analyses}

The phosphorylation status (ratio of phosphorylated to total protein) of key proteins involved in the initiation of muscle protein synthesis are presented in Figure 3.7. Phosphorylation of S6K (Figure 3.7B) decreased in both groups over time (time effect, $P<0.01$ ). Phosphorylation of 4E-BP1 (Figure 3.7D) increased over time and to a greater extent in 15G compared with $15 \mathrm{G}+\mathrm{LEU}(P<0.01)$. 
A
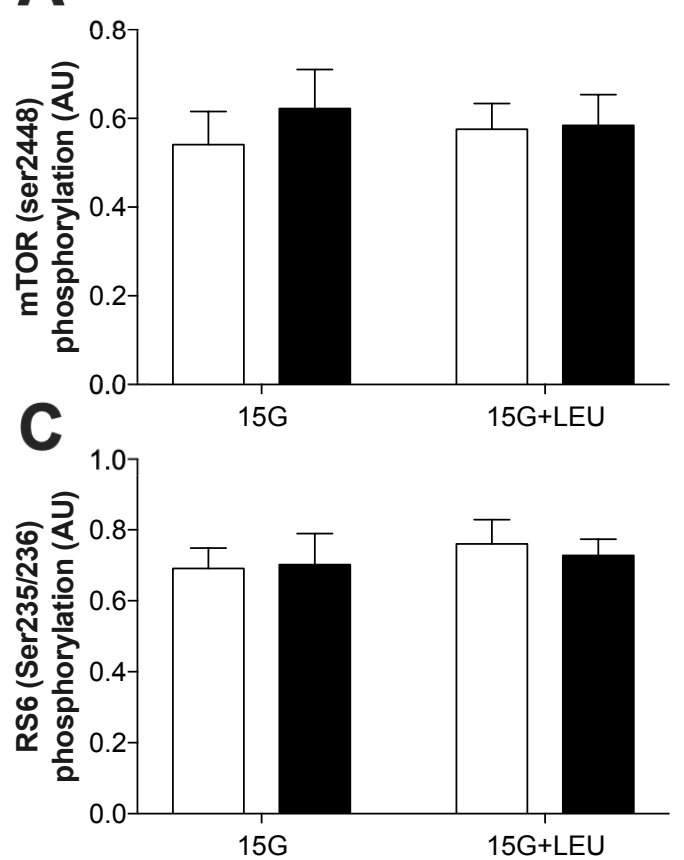

B
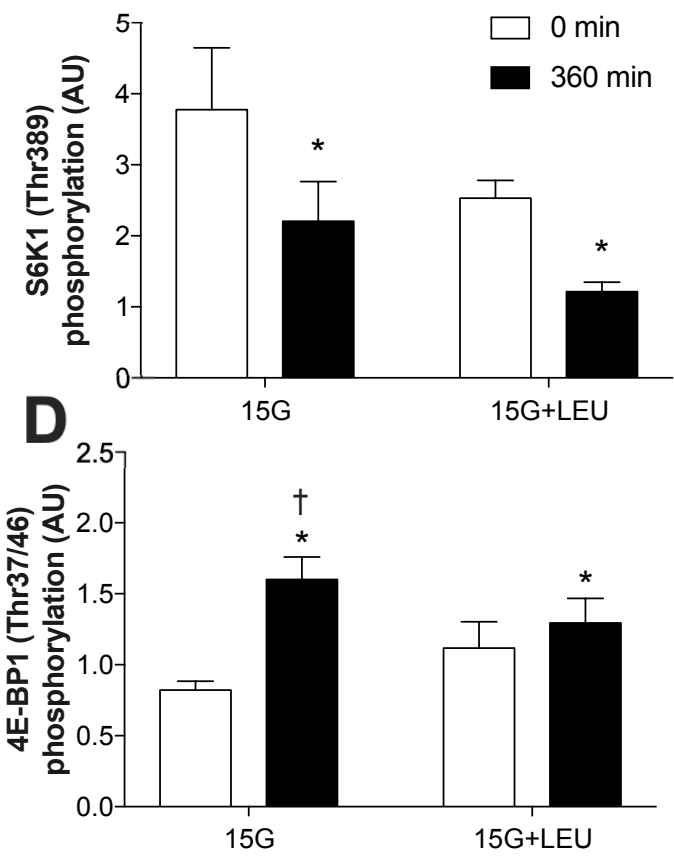

Figure 3.7 Muscle phosphorylation status (ratio of phosphorylated to total protein) of mammalian target of rapamycin (mTOR; A) S6 protein kinase 1 (S6K; B), ribosomal protein S6 (RS6; C), and eukaryotic translation initiation factor $4 E$-binding protein-1 (4E-BP1; D) in older men after resistance-type exercise $(0 \mathrm{~min})$ and 360 min after the ingestion of $15 \mathrm{~g}$ milk protein (15G; $n=12)$ or $15 \mathrm{~g}$ milk protein with $1.5 \mathrm{~g}$ free leucine $(15 \mathrm{G}+\mathrm{LEU}$; $n=12$ ). Values represent means $+S E M$. Data were analyzed with repeated measures (time $x$ treatment group) ANOVA. A; time effect: $P>0.05$, treatment effect: $P>0.05$, time $x$ treatment group: $P>0.05$. $B$; time effect: $P$ $>0.01$, treatment effect: $P>0.05$, time $x$ treatment group: $P>0.05$. $C$; time effect: $P>0.05$, treatment effect: $P>0.05$, time $x$ treatment group: $P>0.05$. D; time effect: $P<0.01$, treatment effect: $P>0.01$, time $x$ treatment group: $P<0.01{ }^{\star}$ Significantly different $(P<0.05)$ compared to $t=0 \mathrm{~min}$. ${ }^{+}$Significant difference $(P<0.05)$ from $15 G+L E U$ at the same time point. 


\section{Discussion}

In the present study, we examined the impact of free leucine co-ingestion on post-prandial protein handling and the subsequent muscle protein synthetic response following the ingestion of $15 \mathrm{~g}$ protein during recovery from resistance-type exercise in older men. We observed that $70-75 \%$ of the dietary-derived amino acids were absorbed into the circulation after ingestion of $15 \mathrm{~g}$ protein. Co-ingesting $1.5 \mathrm{~g}$ free leucine with $15 \mathrm{~g}$ protein further increased post-exercise myofibrillar protein synthesis rates, but did not detectably increase the incorporation of dietary protein-derived amino acids in myofibrillar protein.

We administered a primed, continuous intravenous infusion of $\mathrm{L}-\left[\mathrm{ring}_{-}{ }^{2} \mathrm{H}_{5}\right]$-phenylalanine, $\mathrm{L}$ [ring- $\left.{ }^{2} \mathrm{H}_{2}\right]$-tyrosine and $\mathrm{L}-\left[1-{ }^{13} \mathrm{C}\right]$-leucine throughout a $6 \mathrm{~h}$ post-exercise recovery period in older individuals. Following exercise, participants ingested either $15 \mathrm{~g}$ intrinsically L- $\left[1-{ }^{13} \mathrm{C}\right]-$ phenylalanine labeled milk protein with or without $1.5 \mathrm{~g}$ free leucine. With this experimental protocol, we were able to assess in vivo protein digestion and amino acid absorption kinetics, whole-body protein metabolism, myofibrillar protein synthesis, and the incorporation of dietary protein-derived amino acids in muscle protein (8). After protein ingestion, we observed a rapid rise in circulating plasma amino acid concentrations (Figure 3.3) and an increase in the rate of exogenous phenylalanine appearance (Figure 3.4A), demonstrating rapid protein digestion and subsequent absorption of dietary protein-derived amino acids during post-exercise recovery. As expected, fortification with $1.5 \mathrm{~g}$ free leucine resulted in a greater peak plasma leucine concentration $\left(407 \pm 23\right.$ vs $\left.234 \pm 16 \mu \mathrm{mol} \cdot \mathrm{L}^{-1}, P<0.01\right)$ at $t=$ $30 \mathrm{~min}$, and 1.8-fold greater plasma leucine availability over the entire $6 \mathrm{~h}$ post-prandial period, when compared to the ingestion of $15 \mathrm{~g}$ protein $(P<0.01)$. We observed $70-75 \%$ of dietary protein-derived amino absorption into the circulation over the $6 \mathrm{~h}$ post-prandial period in both groups. This represents a high degree of protein absorption in comparison to recent work from our lab using the same methodology $(16,28,29)$. The discrepancy is likely attributed to the relatively small amount of dietary protein that was provided in the present study along with the extended $6 \mathrm{~h}$ post-prandial assessment period, implying that more protein derived amino acids can be absorbed during a $6 \mathrm{~h}$ post-prandial period when the ingested protein bolus is smaller (Holwerda et al., accepted). Free leucine fortification seemed to compromise protein digestion and/or amino acid absorption as dietary proteinderived phenylalanine availability was lower following leucine co-ingestion when assessed over the entire $6 \mathrm{~h}$ post-prandial period $(10.5 \pm 0.2$ vs $11.2 \pm 0.3 \mathrm{~g} ; P<0.05)$. This was attributed to a mild attenuation of exogenous amino acid appearance rates observed between $t=30-120 \mathrm{~min}$ (Figure 3.4A). It could be speculated that the added free leucine may have stimulated splanchnic amino acid retention of dietary-protein derived amino acids during first pass. In agreement, prior work in neonatal pigs has demonstrated that free leucine co-ingested with a low protein dose stimulates an increase in jejunum, but not liver protein synthesis $(23,33)$. Altogether, our data demonstrate that free leucine co-ingestion 
further increases the post-prandial rise in leucine concentrations but attenuates the rate of appearance of dietary protein-derived amino acids into the circulation.

By administering a primed, continuous intravenous infusion of $\mathrm{L}-\left[\mathrm{ring}_{-}{ }^{2} \mathrm{H}_{5}\right]$-phenylalanine and $\mathrm{L}-\left[\right.$ ring- $\left.{ }^{2} \mathrm{H}_{2}\right]$-tyrosine and providing intrinsically $\mathrm{L}-\left[1-{ }^{13} \mathrm{C}\right]$-phenylalanine labeled protein, we were able to assess post-prandial whole-body protein synthesis, breakdown, net balance and oxidation. In both groups, protein ingestion resulted in a positive whole-body net protein balance during post-exercise recovery. However, fortification with free leucine did not further impact whole-body post-prandial protein synthesis, breakdown or net balance. These findings are in agreement with prior work in older men at rest (32) and in younger men during post-exercise recovery (19). Despite previous reports that leucine administration lowers whole-body amino acid oxidation rates $(18,26)$, we did not observe this effect. These studies achieved far greater plasma leucine availability in comparison to the present study, which may lead to a reduction in protein breakdown rates $(26,36)$ and thereby lower the availability of amino acids for oxidation $(19,36)$. Our present data align with recent work administering similar, meal-like amounts of leucine ( $4.5 \mathrm{~g}$ total) (32), and demonstrate that leucine co-ingestion does not impact whole-body phenylalanine oxidation rates.

Changes in whole-body protein metabolism do not necessarily reflect changes on a muscle level. Therefore, we also collected skeletal muscle biopsies to directly assess the impact of leucine fortification of a low protein dose on intramuscular signaling and the muscle protein synthetic response to feeding. Resistance-type exercise and protein ingestion activate intramuscular signaling proteins that regulate protein translation with $\mathrm{mTOR}$ and its downstream targets, S6 kinase, RS6 and 4E-BP1 being of particular relevance. We observed no differences in mTOR or RS6 phosphorylation, but detected a decrease in S6 kinase phosphorylation over time. These findings align with previous work showing a rapid increase in S6 kinase activity following exercise, which subsides over 3-6 h $(20,45)$. Considering that biopsy timing was intended to assess the muscle protein synthetic response during the entire post-prandial period, it is most likely that transient increases in signaling activity had subsided by $6 \mathrm{~h}$. However, 4E-BP1 phosphorylation increased over time in both groups, and to a greater extent after the ingestion of $15 \mathrm{~g}$ protein when compared with the ingestion of $15 \mathrm{~g}$ with leucine. We speculate that the higher leucine availability in $15 \mathrm{G}+\mathrm{LEU}$ may have transiently activated 4E-BP1 at an earlier time in comparison to $15 \mathrm{G}(12,14,17)$, which steadily activated 4E-BP1 over the $6 \mathrm{~h}$ post-prandial period $(20,43)$.

Combining stable isotope labeled amino acid infusions with ingestion of intrinsically-labeled protein, we were able to assess muscle protein synthesis rates under both steady-state (L$\left[1-{ }^{13} \mathrm{C}\right]$-leucine) as well as non-steady state (L-[ ring- $\left.{ }^{2} \mathrm{H}_{5}\right]$-phenylalanine) precursor conditions (8). Previous work has demonstrated that the ingestion of a low protein dose $(<20 \mathrm{~g})$ following resistance-type exercise does not further stimulate an increase in muscle protein synthesis rates in older individuals $(47,48)$. In the present study, free leucine co-ingested with a low protein dose $(15 \mathrm{~g})$ increased myofibrillar protein synthesis rates by $16 \%$ (L-[ring$\left.{ }^{2} \mathrm{H}_{5}\right]$-phenylalanine, Figure 3.5A) and $19 \%\left(\mathrm{~L}-\left[1-{ }^{13} \mathrm{C}\right]\right.$-leucine, Figure 3.5B) when compared 
with the ingestion of $15 \mathrm{~g}$ protein. These findings are in line with multiple studies demonstrating that free leucine co-ingestion can further increase the muscle protein synthetic response to protein ingestion in older individuals at rest $(2,9,24,42)$ and during recovery from resistance-type exercise $(2,7,9,24)$. In the present study, participants ingested intrinsically L- $\left[1-{ }^{13} \mathrm{C}\right]$-phenylalanine labeled protein, allowing us to directly assess the metabolic fate of the dietary protein-derived amino acids $(16,38,42)$. Despite the greater post-prandial muscle protein synthetic response following the co-ingestion of free leucine, we did not observe a significantly greater $\mathrm{L}-\left[1-{ }^{13} \mathrm{C}\right]$-phenylalanine enrichment in myofibrillar protein in 15G+LEU compared with 15G (Figure 3.6). The absence of a difference in the incorporation of dietary protein-derived amino acids in myofibrillar protein may be related to the mild attenuation in dietary-protein derived phenylalanine availability in the circulation when free leucine was co-ingested (Figure 3.4).

The muscle protein synthetic response to protein ingestion has been shown to be impaired in older (41) and/or more clinically compromised populations $(25,44)$. Resistance-type exercise is an effective strategy to improve the sensitivity of skeletal muscle to the anabolic properties of dietary protein. However, recent work from our group has demonstrated that ingestion of less than $30 \mathrm{~g}$ protein does not further increase the muscle protein synthetic response during post-exercise recovery in older men (Holwerda et al., accepted). We (28) and others $(47,48)$ have shown that increasing protein intake can compensate for this anabolic resistance, with as much as $45 \mathrm{~g}$ of protein being required to achieve a robust anabolic response during exercise recovery in older individuals. However, ingesting such large protein amounts may not be feasible in older and/or more clinically compromised populations. The current data extend upon previous findings and show that free leucine coingestion can augment the post-exercise muscle anabolic response to protein ingestion (2, 7,9 , 24). Therefore, leucine co-ingestion may increase the efficiency by which ingestion of low protein doses enhance the muscle protein synthetic response during recovery from exercise. Simply adding leucine to a post-exercise snack may represent an effective strategy to maintain muscle mass in the older population without the need to ingest large doses of protein. However, few long-term intervention studies have assessed the anabolic effect of leucine co-ingestion on skeletal muscle adaptation. Whereas leucine supplementation does not seem to increase muscle mass in older individuals in resting conditions $(21,39)$, it has been suggested that leucine supplementation might augment resistance training-induced skeletal muscle adaptation (37). Nonetheless, more work is needed to assess the long-term anabolic effects of leucine co-ingestion in combination with exercise training in the older population.

In conclusion, leucine co-ingestion augments the post-exercise muscle protein synthetic response to ingestion of a small amount of protein in older men. 
Leucine co-ingestion increases post-exercise muscle protein synthesis rates

\section{References}

1. American Diabetes Association. Standards of medical care in diabetes--2006. Diabetes Care 29 Suppl 1: S4-42, 2006.

2. Atherton PJ, Kumar V, Selby AL, Rankin D, Hildebrandt W, Phillips BE, Williams JP, Hiscock N, Smith K. Enriching a protein drink with leucine augments muscle protein synthesis after resistance exercise in young and older men. Clin Nutr 36: 888-895, 2017.

3. Atherton PJ, Smith K, Etheridge T, Rankin D, Rennie MJ. Distinct anabolic signalling responses to amino acids in C2C12 skeletal muscle cells. Amino Acids 38: 1533-1539, 2010.

4. Baumgartner RN, Waters DL, Gallagher D, Morley JE, Garry PJ. Predictors of skeletal muscle mass in elderly men and women. Mech Ageing Dev 107: 123-136, 1999.

5. Bergström J, Hultman E. A study of the glycogen metabolism during exercise in man. Scand J Clin Lab Invest 19: 218-228, 1967.

6. Boirie Y, Gachon P, Corny S, Fauquant J, Maubois JL, Beaufrere B. Acute postprandial changes in leucine metabolism as assessed with an intrinsically labeled milk protein. Am J Physiol 271: E1083-91, 1996.

7. Bukhari SSI, Phillips BE, Wilkinson DJ, Limb MC, Rankin D, Mitchell WK, Kobayashi H, Greenhaff PL, Smith K, Atherton PJ. Intake of low-dose leucine-rich essential amino acids stimulates muscle anabolism equivalently to bolus whey protein in older women at rest and after exercise. Am J Physiol Endocrinol Metab 308: E1056-65, 2015.

8. Burd NA, Cermak NM, Kouw IWK, Gorissen SH, Gijsen AP, van Loon LJC. The use of doubly labeled milk protein to measure postprandial muscle protein synthesis rates in vivo in humans. J Appl Physiol 117: 1363-1370, 2014.

9. Churchward-Venne TA, Breen L, Di Donato DM, Hector AJ, Mitchell CJ, Moore DR, Stellingwerff T, Breuille D, Offord EA, Baker SK, Phillips SM. Leucine supplementation of a low-protein mixed macronutrient beverage enhances myofibrillar protein synthesis in young men: a double-blind, randomized trial. Am J Clin Nutr 99: 276-286, 2014.

10. Churchward-Venne TA, Holwerda AM, Phillips SM, van Loon LJC. What is the Optimal Amount of Protein to Support Post-Exercise Skeletal Muscle Reconditioning in the Older Adult? Sports Med 46: 1205-1212, 2016.

11. Dangin M, Guillet C, Garcia-Rodenas C, Gachon P, Bouteloup-Demange C, Reiffers-Magnani K, Fauquant $\mathrm{J}$, Ballèvre $\mathrm{O}$, Beaufrère $\mathrm{B}$. The rate of protein digestion affects protein gain differently during aging in humans. J Physiol 549: 635-644, 2003.

12. Drummond MJ, Dreyer HC, Pennings B, Fry CS, Dhanani S, Dillon EL, Sheffield-Moore M, Volpi E, Rasmussen BB. Skeletal muscle protein anabolic response to resistance exercise and essential amino acids is delayed with aging. J Appl Physiol 104: 1452-1461, 2008.

13. Fujita S, Dreyer HC, Drummond MJ, Glynn EL, Cadenas JG, Yoshizawa F, Volpi E, Rasmussen BB. Nutrient signalling in the regulation of human muscle protein synthesis. J Physio/ 582: 813-823, 2007.

14. Glynn EL, Fry CS, Drummond MJ, Timmerman KL, Dhanani S, Volpi E, Rasmussen BB. Excess Leucine Intake Enhances Muscle Anabolic Signaling but Not Net Protein Anabolism in Young Men and Women. $J$ Nutr 140: 1970-1976, 2010.

15. Gorissen SHM, Burd NA, Hamer HM, Gijsen AP, Groen BB, van Loon LJC. Carbohydrate coingestion delays dietary protein digestion and absorption but does not modulate postprandial muscle protein accretion. J Clin Endocrinol Metab 99: 2250-2258, 2014.

16. Groen BBL, Horstman AM, Hamer HM, de Haan M, van Kranenburg J, Bierau J, Poeze M, Wodzig WKWH, Rasmussen BB, van Loon LJC. Post-Prandial Protein Handling: You Are What You Just Ate. PLoS ONE 10: e0141582, 2015

17. Koopman R, Pennings B, Zorenc AHG, van Loon LJC. Protein ingestion further augments S6K1 phosphorylation in skeletal muscle following resistance type exercise in males. J Nutr 137: 1880-1886, 2007.

18. Koopman R, Verdijk LB, Beelen M, Gorselink M, Kruseman AN, Wagenmakers AJM, Kuipers $H$, van Loon LJC. Co-ingestion of leucine with protein does not further augment post-exercise muscle protein synthesis rates in elderly men. Br J Nutr 99: 1-10, 2007. 
19. Koopman R, Wagenmakers AJM, Manders RJF, Zorenc AHG, Senden JMG, Gorselink M, Keizer HA, van Loon LJC. Combined ingestion of protein and free leucine with carbohydrate increases postexercise muscle protein synthesis in vivo in male subjects. Am J Physiol Endocrinol Metab 288: E645-53, 2005.

20. Koopman R, Zorenc AHG, Gransier RJJ, Cameron-Smith D, van Loon LJC. Increase in S6K1 phosphorylation in human skeletal muscle following resistance exercise occurs mainly in type II muscle fibers. Am J Physiol Endocrinol Metab 290: E1245-52, 2006.

21. Leenders M, Verdijk LB, van der Hoeven L, van Kranenburg J, Hartgens F, Wodzig WKWH, Saris WHM, van Loon LJC. Prolonged leucine supplementation does not augment muscle mass or affect glycemic control in elderly type 2 diabetic men. J Nutr 141: 1070-1076, 2011.

22. Mayhew JL, Prinster JL, Ware JS, Zimmer DL, Arabas JR, Bemben MG. Muscular endurance repetitions to predict bench press strength in men of different training levels. J Sports Med Phys Fitness 35: 108113, 1995.

23. Murgas Torrazza R, Suryawan A, Gazzaneo MC, Orellana RA, Frank JW, Nguyen HV, Fiorotto ML, ElKadi S, Davis TA. Leucine Supplementation of a Low-Protein Meal Increases Skeletal Muscle and Visceral Tissue Protein Synthesis in Neonatal Pigs by Stimulating mTOR-Dependent Translation Initiation. J Nutr 140: 2145-2152, 2010.

24. Murphy CH, Saddler NI, Devries MC, McGlory C, Baker SK, Phillips SM. Leucine supplementation enhances integrative myofibrillar protein synthesis in free-living older men consuming lower- and higherprotein diets: a parallel-group crossover study. Am J Clin Nutr 104: 1594-1606, 2016.

25. Murton AJ, Marimuthu K, Mallinson JE, Selby AL, Smith K, Rennie MJ, Greenhaff PL. Obesity Appears to Be Associated With Altered Muscle Protein Synthetic and Breakdown Responses to Increased Nutrient Delivery in Older Men, but Not Reduced Muscle Mass or Contractile Function. Diabetes 64: 3160-3171, 2015.

26. Nair KS, Matthews DE, Welle SL, Braiman T. Effect of leucine on amino acid and glucose metabolism in humans. Metabolism 41: 643-648, 1992.

27. Paddon-Jones D, Sheffield-Moore M, Zhang X-J, Volpi E, Wolf SE, Aarsland A, Ferrando AA, Wolfe RR. Amino acid ingestion improves muscle protein synthesis in the young and elderly. Am J Physiol Endocrinol Metab 286: E321-8, 2004.

28. Pennings B, Groen B, de Lange A, Gijsen AP, Zorenc AH, Senden JMG, van Loon LJC. Amino acid absorption and subsequent muscle protein accretion following graded intakes of whey protein in elderly men. Am J Physiol Endocrinol Metab 302: E992-9, 2012.

29. Pennings B, Groen BBL, van Dijk J-W, de Lange A, Kiskini A, Kuklinski M, Senden JMG, van Loon LJC Minced beef is more rapidly digested and absorbed than beef steak, resulting in greater postprandial protein retention in older men. Am J Clin Nutr 98: 121-128, 2013.

30. Pennings B, Koopman R, Beelen M, Senden JMG, Saris WHM, van Loon LJC. Exercising before protein intake allows for greater use of dietary protein-derived amino acids for de novo muscle protein synthesis in both young and elderly men. Am J Clin Nutr 93: 322-331, 2011.

31. Res PT, Groen B, Pennings B, Beelen M, Wallis GA, Gijsen AP, Senden JMG, van Loon LJC. Protein ingestion before sleep improves postexercise overnight recovery. Med Sci Sports Exerc 44: 1560-1569, 2012.

32. Rieu I, Balage M, Sornet C, Giraudet C, Pujos E, Grizard J, Mosoni L, Dardevet D. Leucine supplementation improves muscle protein synthesis in elderly men independently of hyperaminoacidaemia. J Physiol 575: 305-315, 2006.

33. Suryawan A, Torrazza RM, Gazzaneo MC, Orellana RA, Fiorotto ML, El-Kadi SW, Srivastava N, Nguyen HV, Davis TA. Enteral leucine supplementation increases protein synthesis in skeletal and cardiac muscles and visceral tissues of neonatal pigs through mTORC1-dependent pathways. Pediatr Res 71: 324-331, 2012.

34. Tieland M, Borgonjen-Van den Berg KJ, van Loon LJC, de Groot LCPGM. Dietary protein intake in community-dwelling, frail, and institutionalized elderly people: scope for improvement. Eur J Nutr 51: 173-179, 2012.

35. Tieland M, Borgonjen-Van den Berg KJ, van Loon LJC, de Groot LCPGM. Dietary Protein Intake in Dutch Elderly People: A Focus on Protein Sources. Nutrients 7: 9697-9706, 2015.

36. Tom A, Nair KS. Assessment of Branched-Chain Amino Acid Status and Potential for Biomarkers. J Nutr 136: 324S-330S, 2006. 
37. Trabal J, Forga M, Leyes P, Torres F, Rubio J, Prieto E, Farran-Codina A. Effects of free leucine supplementation and resistance training on muscle strength and functional status in older adults: a randomized controlled trial. CIA Volume 10: 713-11, 2015.

38. van Loon LJC, Boirie Y, Gijsen AP, Fauquant J, de Roos AL, Kies AK, Lemosquet S, Saris WHM Koopman $\mathbf{R}$. The production of intrinsically labeled milk protein provides a functional tool for human nutrition research. J Dairy Sci 92: 4812-4822, 2009.

39. Verhoeven S, Vanschoonbeek K, Verdijk LB, Koopman R, Wodzig WK, Dendale P, van Loon LJ. Longterm leucine supplementation does not increase muscle mass or strength in healthy elderly men. Am J Clin Nutr 89: 1468-1475, 2009

40. Wall BT, Burd NA, Franssen R, Gorissen SHM, Snijders T, Senden JM, Gijsen AP, van Loon LJC. Presleep protein ingestion does not compromise the muscle protein synthetic response to protein ingested the following morning. Am J Physiol Endocrinol Metab 311: E964-E973, 2016.

41. Wall BT, Gorissen SH, Pennings B, Koopman R, Groen BBL, Verdijk LB, van Loon LJC. Aging Is Accompanied by a Blunted Muscle Protein Synthetic Response to Protein Ingestion. PLoS ONE 10: e0140903, 2015.

42. Wall BT, Hamer HM, de Lange A, Kiskini A, Groen BBL, Senden JMG, Gijsen AP, Verdijk LB, van Loon LJC. Leucine co-ingestion improves post-prandial muscle protein accretion in elderly men. Clin Nutr 32: 412-419, 2013.

43. West DW, Burd NA, Coffey VG, Baker SK, Burke LM, Hawley JA, Moore DR, Stellingwerff T, Phillips SM. Rapid aminoacidemia enhances myofibrillar protein synthesis and anabolic intramuscular signaling responses after resistance exercise. Am J Clin Nutr 94: 795-803, 2011.

44. Williams JP, Phillips BE, Smith K, Atherton PJ, Rankin D, Selby AL, Liptrot S, Lund J, Larvin M, Rennie MJ. Effect of tumor burden and subsequent surgical resection on skeletal muscle mass and protein turnover in colorectal cancer patients. Am J Clin Nutr 96: 1064-1070, 2012.

45. Witard OC, Tieland M, Beelen M, Tipton KD, van Loon LJC, Koopman R. Resistance exercise increases postprandial muscle protein synthesis in humans. Med Sci Sports Exerc 41: 144-154, 2009.

46. Wolfe RR, Chinkes DL. Isotope tracers in metabolic research: principles and practice of kinetic analysis. 2005.

47. Yang Y, Breen L, Burd NA, Hector AJ, Churchward-Venne TA, Josse AR, Tarnopolsky MA, Phillips SM Resistance exercise enhances myofibrillar protein synthesis with graded intakes of whey protein in older men. Br J Nutr 108: 1780-1788, 2012.

48. Yang Y, Churchward-Venne TA, Burd NA, Breen L, Tarnopolsky MA, Phillips SM. Myofibrillar protein synthesis following ingestion of soy protein isolate at rest and after resistance exercise in elderly men. Nutr Metab 9: 57, 2012. 



\section{Chapter 4}

Physical activity performed in the evening increases the overnight muscle protein synthetic response to pre-sleep protein ingestion in older men

Andrew M. Holwerda, Imre W.K. Kouw, Jorn Trommelen, Shona L. Halson, Will K. W. H. Wodzig, Lex B. Verdijk and Luc J.C. van Loon 
Chapter 4

\section{Abstract}

Background The age-related decline in skeletal muscle mass is, at least partly, attributed to anabolic resistance to food intake. We recently introduced the ingestion of dietary protein prior to sleep as a nutritional strategy to augment overnight muscle protein synthesis rates in older men.

Objective The present study aimed to assess whether physical activity performed in the evening can augment the overnight muscle protein synthetic response to presleep protein ingestion in older men.

Methods In a parallel group design, twenty-three healthy older men (71 \pm 1 y) were randomly assigned to ingest $40 \mathrm{~g}$ intrinsically $\mathrm{L}-\left[1-{ }^{13} \mathrm{C}\right]$-phenylalanine and $\mathrm{L}-[1$ ${ }^{13} \mathrm{C}$-leucine labeled casein protein before going to sleep with (PRO+EX: $n=$ 11) or without (PRO: $n=12$ ) a bout of physical activity being performed earlier in the evening. Overnight protein digestion and absorption kinetics and myofibrillar protein synthesis rates were assessed by combining primed, continuous infusions of $\mathrm{L}-\left[\right.$ ring- $\left.{ }^{2} \mathrm{H}_{5}\right]$-phenylalanine, $\mathrm{L}-\left[1-{ }^{13} \mathrm{C}\right]$-leucine and $\mathrm{L}$ [ring $\left.-{ }^{2} \mathrm{H}_{2}\right]$-tyrosine with the ingestion of intrinsically $\mathrm{L}-\left[1-{ }^{13} \mathrm{C}\right]$-phenylalanine and $\mathrm{L}-\left[1-{ }^{13} \mathrm{C}\right]$-leucine labeled casein protein. Muscle and blood samples were collected throughout overnight sleep.

Results We observed that protein ingested prior to sleep was normally digested and absorbed, with $54 \pm 2 \%$ of the ingested protein-derived amino acids appearing in the circulation throughout overnight sleep. Overnight myofibrillar protein synthesis rates were $31 \%(0.058 \pm 0.002$ vs $0.044 \pm 0.003$ $\% \cdot h^{-1}, P<0.01$; based upon L-[ring- $\left.{ }^{2} \mathrm{H}_{5}\right]$-phenylalanine $)$ and $27 \%(0.074 \pm$ 0.004 vs $0.058 \pm 0.003 \% \cdot h^{-1}, P<0.01$; based upon L-[1-13 C]-leucine) higher in $\mathrm{PRO}+\mathrm{EX}$ compared to PRO. Substantially more of the dietary protein-derived amino acids were incorporated into de novo myofibrillar protein during overnight sleep in PRO+EX compared to PRO $(0.042 \pm 0.002$ vs $0.033 \pm 0.002$ MPE, $P<0.05)$

Conclusions Physical activity performed in the evening augments the overnight muscle protein synthetic response to pre-sleep protein ingestion and allows more of the ingested protein-derived amino acids to be used for de novo muscle protein synthesis during overnight sleep in older men. 


\section{Introduction}

The age-related decline in muscle mass and strength, termed sarcopenia, is accompanied by impairments in functional capacity and an increased risk of developing chronic metabolic diseases $(1,18)$. With no apparent differences in basal, post-absorptive muscle protein synthesis rates between young and older individuals $(14,23)$, many research groups have started to investigate the muscle protein synthetic response to the main anabolic stimuli, such as food intake and physical activity. This has led to the observation of an attenuated muscle protein synthetic response to food intake in older individuals $(8,13)$, a condition that has been coined anabolic resistance (6).

Effective strategies are needed to augment the muscle protein synthetic response to feeding as a means to compensate for the presence of anabolic resistance. Therefore, our laboratory and many others are investigating nutritional strategies to increase the muscle protein synthetic response to meal ingestion. Such interventions may include modulating the amount $(25,38,39)$, type $(15,22,24)$, and timing $(16,20)$ of protein ingestion, as well as combining protein ingestion with various food compounds $(11,31)$. Besides enhancing the muscle protein synthetic response to the main meals (i.e., breakfast, lunch and dinner), we have proposed the ingestion of dietary protein prior to sleep with the aim of providing dietaryderived amino acids to support an increase in overnight muscle protein synthesis $(12,29)$. In a proof-of-principle study, Groen et al. (12) demonstrated that enteral administration of 40 $\mathrm{g}$ protein during sleep via a nasogastric tube was followed by proper protein digestion and absorption, thereby increasing overnight amino acid availability and stimulating overnight muscle protein synthesis rates in older individuals. Therefore, we proposed dietary protein ingestion prior to sleep as a practical and effective strategy to improve overnight protein balance and stimulate overnight muscle protein synthesis.

Physical activity is an important factor responsible for the level of anabolic resistance $(6,33)$. Previous work has established that physical activity or exercise can robustly increase muscle protein synthesis rates $(3,19,27,28)$. Moreover, physical activity augments the post-prandial muscle protein synthetic response to protein feeding, thereby compensating for the level of anabolic resistance $(27,38,39)$. Here, we hypothesized that physical activity performed during the evening would augment the overnight muscle protein synthetic response to presleep protein ingestion, allowing more of the ingested protein to be used for de novo myofibrillar protein accretion during sleep.

To test our hypothesis that physical activity can augment the impact of pre-sleep protein ingestion on overnight muscle protein synthesis, we selected 23 older men (71 \pm 1 y) who ingested $40 \mathrm{~g}$ intrinsically $\mathrm{L}-\left[1-{ }^{13} \mathrm{C}\right]$-phenylalanine and L- $\left[1-{ }^{13} \mathrm{C}\right]$-leucine labeled casein protein before going to sleep with (PRO+EX: $n=11$ ) or without (PRO: $n=12$ ) a bout of physical activity being performed earlier in the evening. By combining the ingestion of specifically produced intrinsically $\mathrm{L}-\left[1-{ }^{13} \mathrm{C}\right]$-phenylalanine and $\mathrm{L}-\left[1-{ }^{13} \mathrm{C}\right]$-leucine labeled casein with administration of primed continuous infusions of $\mathrm{L}-\left[\right.$ ring- $\left.{ }^{2} \mathrm{H}_{5}\right]$-phenylalanine, $\mathrm{L}-\left[1-{ }^{13} \mathrm{C}\right]-$ leucine 
Chapter 4

and L-[ring- $\left.{ }^{2} \mathrm{H}_{2}\right]$-tyrosine we were able to assess overnight protein digestion and amino acid absorption kinetics, whole-body protein metabolism, muscle protein synthesis rates, as well as the metabolic fate of the dietary protein-derived amino acids towards de novo myofibrillar protein accretion during overnight sleep. 


\title{
Materials and methods
}

\author{
Subjects
}

A total of 24 healthy, normoglycemic, older men $(71 \pm 1$ y) were selected to participate in the present study. Subject characteristics of the study participants are presented in Table 4.1. Subjects were randomly assigned to ingest $40 \mathrm{~g}$ intrinsically $\mathrm{L}-\left[1-{ }^{13} \mathrm{C}\right]$-phenylalanine and $\mathrm{L}-\left[1-{ }^{13} \mathrm{C}\right]$-leucine labeled casein protein before going to sleep with (PRO+EX: $n=11$ ) or without (PRO: $n=12$ ) a bout of physical activity being performed earlier in the evening. One subject randomized to the $\mathrm{PRO}+\mathrm{EX}$ group did not complete the physical activity session and was therefore excluded from all analyses. All subjects were informed of the nature and possible risks of the experimental procedures before their written informed consent was obtained. The study was approved by the Medical Ethical Committee of the Maastricht University Medical Centre, The Netherlands, and conformed to standards for the use of human subjects in research as outlined in the most recent version of the Helsinki Declaration. The study was registered at Nederlands Trial Register as NTR3885.

Table 4.1 Subjects characteristics of healthy older men who ingested $40 \mathrm{~g}$ protein prior to sleep after either completing a session of resistance exercise or remaining at rest ${ }^{1}$

\begin{tabular}{lccc}
\hline & & & \\
& PRO $(\boldsymbol{n}=\mathbf{1 2})$ & PRO+EX $(\boldsymbol{n}=\mathbf{1 1})$ & $\boldsymbol{P}$ \\
\hline Age, $\mathrm{y}$ & $70 \pm 1$ & $71 \pm 1$ & 0.48 \\
Body weight, $\mathrm{kg}$ & $79.4 \pm 2.2$ & $79.0 \pm 2.2$ & 0.88 \\
Body mass index, $\mathrm{kg} \cdot \mathrm{m}^{-2}$ & $25.7 \pm 0.6$ & $26.0 \pm 0.7$ & 0.71 \\
Body fat, \% & $20.8 \pm 0.9$ & $20.9 \pm 1.3$ & 0.92 \\
Lean body mass, $\mathrm{kg}$ & $60.6 \pm 1.4$ & $60.1 \pm 1.8$ & 0.84 \\
Appendicular lean mass, $\mathrm{kg}$ & $26.2 \pm 0.7$ & $25.9 \pm 0.9$ & 0.78 \\
Leg volume, L & $8.4 \pm 0.5$ & $8.1 \pm 0.5$ & 0.70 \\
HbA1c, \% & $5.3 \pm 0.1$ & $5.5 \pm 0.1$ & 0.43 \\
Basal plasma glucose, $\mathrm{mmol} \cdot \mathrm{L}^{-1}$ & $6.4 \pm 0.3$ & $5.8 \pm 0.2$ & 0.08 \\
Basal plasma insulin, $\mathrm{mU} \cdot \mathrm{L}^{-1}$ & $10.6 \pm 1.3$ & $8.5 \pm 1.1$ & 0.24 \\
HOMA-IR & $2.2 \pm 0.3$ & $3.1 \pm 0.4$ & 0.09 \\
1RM Leg Press, $\mathrm{kg}$ & - & $170 \pm 8$ & - \\
1RM Leg Extension, $\mathrm{kg}$ & - & $77 \pm 5$ & - \\
PSOl Score & $2.3 \pm 0.3$ & $2.8 \pm 0.5$ & 0.48 \\
\hline
\end{tabular}

${ }^{1}$ Values are expressed as means \pm SEM. PRO treatment, $n=12 ; P R O+E X$ treatment, $n=11 ; H b A 1 c$, glycated hemoglobin; HOMA-IR, homeostasis model assessment of insulin resistance, $1 R M$, one repetition maximum. PSQI, Pittsburg Sleep Quality Index. No differences were observed between treatment groups.

\section{Pretesting}

Participants arrived at the laboratory at $0830 \mathrm{~h}$ by car or public transport in an overnight fasted state. Upon arrival, body weight, body composition, and bone mineral content were measured with DEXA (Dual-energy X-ray absorptiometry, DEXA; Discovery A; Hologic, 
Bedford, MA). Thereafter, all participants performed an oral glucose tolerance test (OGTT). Plasma glucose and insulin concentrations were measured to determine oral glucose intolerance and/or the presence of type 2 diabetes according to 2006 American Diabetes Association guidelines (10). All subjects were screened on medical issues and excluded if any gastrointestinal, neurological or renal diseases were present.

Subjects randomized into the PRO+EX group were cleared to perform physical activity by a cardiologist who examined electrocardiograms (ECG) measured at rest and during submaximal cycling (performed at $70 \%$ of age-predicted heart rate max). The subjects were then familiarized with the exercise equipment and physical activity protocol. Subjects first performed a 10-min cycling warm-up at $70 \%$ of their age-predicted heart rate max before completing an estimation of their 1RM (one repetition maximum) on the leg press and leg extension exercises using the multiple repetitions testing procedure (17). For each exercise, subjects performed 10 submaximal, or warm-up repetitions to become familiarized with the equipment and to have lifting technique critiqued and corrected. Subjects then performed sets at progressively increasing loads until failing to complete a valid repetition, judged by their inability to complete the full range of motion for an exercise. Ideally, subjects failed within 3-6 repetitions during the last and heaviest set. A 2-min resting period between subsequent attempts was allowed. The pretesting and experimental trials were separated by a period of at least 7 days.

\section{Diet and physical activity}

All volunteers were instructed to refrain from any exhaustive physical activity and to keep their diet as consistent as possible $48 \mathrm{~h}$ prior to the trial. On the day of the experiment, a standardized diet ( 3 meals and 2 snacks) was consumed which provided $9.3 \pm 0.6 \mathrm{MJ}$, with $55 \pm 2$ energy\% (En\%) as carbohydrate, $27 \pm 2 \mathrm{En} \%$ as fat, and $16 \pm 0.2 \mathrm{En} \%$ as protein. The energy content of the standardized diet was based upon individual energy requirements calculated using the Harris-Benedict equation and adjusted using a physical activity factor of 1.4 to ensure ample energy intake. Dietary protein intake averaged $1.1 \pm 0.01 \mathrm{~g}^{\mathrm{kg}}{ }^{-1}$ bodyweight, with $35 \pm 1 \%$ of the protein consumed at dinner.

\section{Experimental Protocol}

An overview of the experimental protocol is depicted in Figure 4.1. At $1730 \mathrm{~h}$, participants reported to the lab and had Teflon catheters inserted into the antecubital veins of each arm. At $1830 \mathrm{~h}$ ( $t=-300 \mathrm{~min})$, all subjects consumed the same standardized dinner meal under supervision (2.5 $\pm 0.1 \mathrm{MJ}$, providing $62 \pm 0.2 \mathrm{En} \%$ carbohydrate, $19 \pm 0.1 \mathrm{En} \%$ fat, and $19 \pm$ $0.1 \mathrm{En} \%$ protein). Subjects in the PRO+EX group performed a single physical activity session between $1945 \mathrm{~h}$ and $2045 \mathrm{~h}$. After the physical activity session, and at $2100 \mathrm{~h}$ ( $t=-150 \mathrm{~min}$ ), a background blood sample was taken prior to the initiation of the tracer infusion protocol. The plasma and intracellular phenylalanine and leucine pools were primed with a single 
intravenous dose (priming dose) of L-[ ring- $\left.{ }^{2} \mathrm{H}_{5}\right]$-phenylalanine $\left(2.0 \mu \mathrm{mol} \cdot \mathrm{kg}^{-1}\right), \mathrm{L}-\left[\right.$ ring $\left.^{2} \mathrm{H}_{2}\right]-$ tyrosine $\left(0.615 \mu \mathrm{mol} \cdot \mathrm{kg}^{-1}\right), \mathrm{L}-\left[1{ }^{13} \mathrm{C}\right]$-leucine $\left(4.0 \mu \mathrm{mol} \cdot \mathrm{kg}^{-1}\right)$. Once primed, the continuous stable isotope infusion was initiated (infusion rate: $0.05 \mu \mathrm{mol} \cdot \mathrm{kg}^{-1} \cdot \mathrm{min}^{-1} \mathrm{~L}$-[ring- ${ }^{2} \mathrm{H}_{5}$ ] phenylalanine, $0.015 \mu \mathrm{mol} \cdot \mathrm{kg}^{-1} \cdot \mathrm{min}^{-1} \mathrm{~L}$-[ring- $\left.{ }^{2} \mathrm{H}_{2}\right]$-tyrosine, $0.1 \mu \mathrm{mol} \cdot \mathrm{kg}^{-1} \cdot \mathrm{min}^{-1} \mathrm{~L}-\left[1{ }^{-13} \mathrm{C}\right]-$ leucine: Cambridge Isotopes Laboratories, Andover, MA). Participants rested for $2.5 \mathrm{~h}$ until $2330 \mathrm{~h}$ ( $t=0 \mathrm{~min}$ ), when the first muscle biopsy sample was taken. Subsequently, subjects ingested a $450 \mathrm{~mL}$ beverage containing $40 \mathrm{~g}$ intrinsically L- $\left[1-{ }^{13} \mathrm{C}\right]$-phenylalanine and L-[1${ }^{13} \mathrm{C}$-leucine labeled casein, and $1.5 \mathrm{~mL}$ of vanilla extract added to improve palatability (Dr. Oetker, Amersfoort, the Netherlands) within 5 min. Subjects went to sleep at $0000 \mathrm{~h}$. During the night, blood samples $(10 \mathrm{~mL})$ were taken without waking up the subjects at $t=30,60$, $90,150,210,270,330,390,450$ min relative to the intake of the protein drink. A second muscle biopsy was obtained from the contralateral leg $7.5 \mathrm{~h}$ later at $0700 \mathrm{~h}$ ( $t=450 \mathrm{~min}$ ).

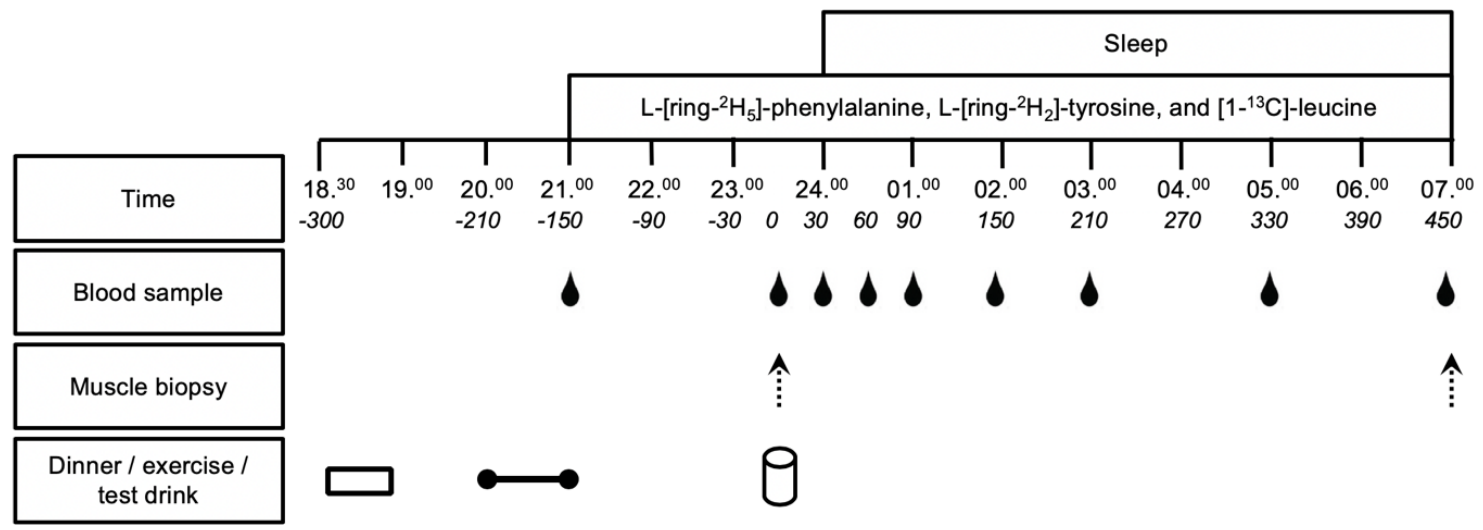

Figure 4.1 Graphical representation of the experimental protocol.

Blood samples were collected in EDTA containing tubes and centrifuged at $1000 \mathrm{~g}$ for 10 min at $4{ }^{\circ} \mathrm{C}$. Aliquots of plasma were frozen in liquid nitrogen and stored at $-80{ }^{\circ} \mathrm{C}$. Muscle biopsies were obtained from the middle region of the $M$. vastus lateralis, $15 \mathrm{~cm}$ above the patella and approximately $4 \mathrm{~cm}$ below entry through the fascia, using the percutaneous needle biopsy technique (2). Muscle samples were dissected carefully and freed from any visible non-muscle material. The muscle samples were immediately frozen in liquid nitrogen and stored at $-80^{\circ} \mathrm{C}$ until further analysis.

\section{Physical activity protocol}

The physical activity protocol consisted of $60 \mathrm{~min}$ of moderate intensity lower-body resistance-type exercise. After 15 min of self-paced cycling at $100 \mathrm{~W}$ with a cadence of 60 80 RPM, subjects performed 6 sets of 10 repetitions on the horizontal leg press machine (Technogym BV, Rotterdam, Netherlands) and 6 sets of 10 repetitions on the leg extension machine (Technogym BV). The first two sets of both exercises were performed at 55 and 65 
$\% 1 \mathrm{RM}$, respectively and sets 3-6 were performed at $75 \% 1 \mathrm{RM}$. Subjects were allowed to rest for 2 min between all sets.

Sleep quality assessment

The Pittsburg Sleep Quality Index (PSOI, Sleep Medicine Institute, University of Pittsburgh) was used to assess habitual sleep quality during pretesting (7). PSOl scoring (global scores 0-21 points) was used to classify all subjects to very good, good, poor or very poor sleepers. Subjects that scored $>5$ (poor sleepers) were not included in the trial. Sleep behavior during the test night was monitored using wrist activity monitors and analyzed using

Actiware software (Philips Respironics, Bend, Oregon). Time was scored as awake unless the following conditions were met simultaneously: (a) participant was lying down attempting to sleep; (b) the activity counts from the monitor were sufficiently low to indicate that the participant was immobile. Additionally, the start and end time of sleep were recorded throughout the trial. The following parameters were derived from sleep records and activity monitors: bed time (clock time), get up time (clock time), sleep onset latency (the period of time between bedtime and sleep start), sleep duration ( $h$ ), time awake/light sleep ( $h$ ), sleep efficiency (sleep duration expressed as a percentage of time in bed), and wake bouts.

\section{Preparation of tracer and production of intrinsically labeled protein}

The stable isotope tracers $\mathrm{L}-\left[\right.$ ring $\left.-{ }^{2} \mathrm{H}_{5}\right]$-phenylalanine, L-[1- $\left.1{ }^{13} \mathrm{C}\right]$-leucine and L-[ring $\left.-{ }^{2} \mathrm{H}_{2}\right]-$ tyrosine were purchased from Cambridge Isotopes (Andover, MA) and dissolved in $0.9 \%$ saline before infusion (Basic Pharma, Geleen, the Netherlands). Continuous intravenous infusions were performed using a calibrated IVAC 598 pump (San Diego, CA, USA). Intrinsically L- $\left[1-{ }^{13} \mathrm{C}\right]$-phenylalanine and L- $\left[1-{ }^{13} \mathrm{C}\right]$-leucine labeled casein protein was extracted from whole milk obtained during the constant infusion of $\mathrm{L}-\left[1-{ }^{13} \mathrm{C}\right]$-phenylalanine $(455$ $\left.\mu \mathrm{mol} \cdot \mathrm{min}^{-1}\right)$ and $\mathrm{L}-\left[1{ }^{13} \mathrm{C}\right]$-leucine $\left(200 \mu \mathrm{mol} \cdot \mathrm{min}^{-1}\right)$ for $96 \mathrm{~h}$ in a lactating dairy cow. The milk was collected, processed, and fractionated into the casein protein concentrate as previously described $(11,29,32)$. The $\mathrm{L}-\left[1-{ }^{13} \mathrm{C}\right]$-phenylalanine and $\mathrm{L}-\left[1-{ }^{13} \mathrm{C}\right]$-leucine enrichments in casein protein were measured by gas chromatography-combustion-isotope ratio mass spectrometry (GC-C-IRMS; MAT 252, Finnigan, Breman, Germany) and averaged 38.7 mole percent excess (MPE) and 9.3 MPE, respectively. The proteins met all chemical and bacteriological specifications for human consumption.

Plasma and muscle analysis

Plasma glucose and insulin concentrations were analyzed using commercially available kits (GLUC3, Roche, Ref: 05168791 190, and Immunologic, Roche, Ref: 12017547 122, respectively). Plasma amino acid concentrations and enrichments were determined by gas 
chromatography-mass spectrometry analysis (GC-MS; Agilent 7890A GC/5975C; MSD, Wilmington, Delaware, USA). Myofibrillar protein-bound L-[ring- $\left.{ }^{2} \mathrm{H}_{5}\right]$-phenylalanine enrichments were determined by GC-MS analysis, whereas the $\mathrm{L}-\left[1-{ }^{13} \mathrm{C}\right]$-phenylalanine and $\mathrm{L}-\left[1-{ }^{13} \mathrm{C}\right]$-leucine enrichments were determined by GC-C-isotope ratio mass spectrometer analysis (GC-C-IRMS; Trace GC Ultra, IRMS model MAT 253; Thermo Scientific). For complete details, see the Materials and methods section in Chapter 2.

\section{Calculations}

Ingestion of L- $\left[1-{ }^{13} \mathrm{C}\right]$-phenylalanine labeled protein, intravenous infusion of L-[ ring- $\left.{ }^{2} \mathrm{H}_{5}\right]-$ phenylalanine, and blood sample enrichment values were used to assess whole-body amino acid kinetics in non-steady state conditions. Total, exogenous, and endogenous phenylalanine rates of appearance $\left(R_{a}\right)$ and plasma availability of dietary protein-derived phenylalanine that appeared in the systemic circulation as a fraction of total amount of

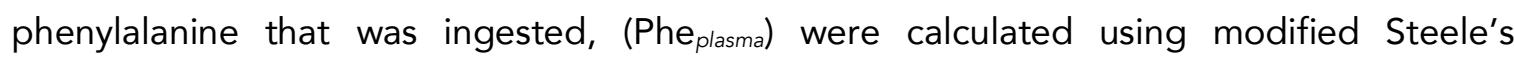
equations $(4,9,37)$. Myofibrillar protein fractional synthetic rate (FSR) was calculated using the standard precursor-product method. For complete details, see the Materials and methods section in Chapter 2.

\section{Statistics}

All data are expressed as mean \pm SEM. Baseline characteristics between groups were compared using a student's unpaired t-test. A two-factor repeated measures ANOVA (time $x$ treatment) with time as within-subjects factor and treatment group as between-subjects factor was performed for the analysis of plasma amino acid concentrations, plasma tracer enrichments, whole-body kinetics and glucose and insulin concentrations. The analysis was carried out for the period starting at the time of protein administration, between $t=0$ and $450 \mathrm{~min}$. Upon identification of a significant time $\mathrm{x}$ treatment interaction, Bonferroni post hoc testing was used to identify time points in which the treatments differed. Non timedependent variables (i.e., Whole-body metabolism, FSR values, L-[1- $\left.{ }^{13} \mathrm{C}\right]$-phenylalanine myofibrillar enrichments) were compared between treatment groups using a Student's unpaired $t$-test. Statistical significance was set at $P<0.05$. All calculations were performed using SPSS 21.0 (SPSS inc., Chicago, Illinois, USA). 


\section{Results}

Plasma analysis

Overnight plasma glucose (Figure 4.2A) and insulin (Figure 4.2B) concentrations after presleep protein ingestion did not differ between the PRO and PRO+EX groups $(P \geq 0.05)$. Plasma insulin concentrations increased after protein ingestion in both treatments, reaching peak levels after $t=30 \mathrm{~min}$.

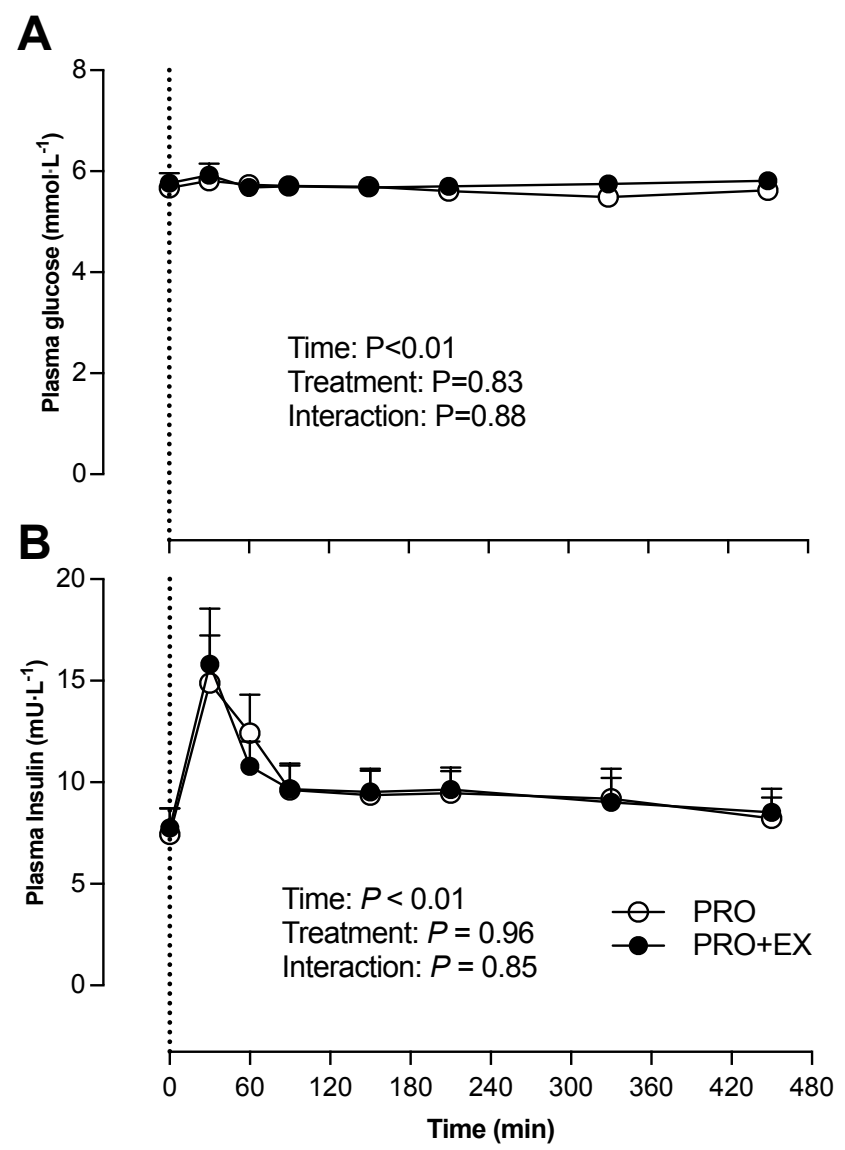

Figure 4.2 Overnight plasma glucose $\left(A, \mathrm{mmol} \cdot \mathrm{L}^{-1}\right)$ and insulin concentrations $\left(B, \mathrm{mU} \cdot \mathrm{L}^{-1}\right)$ following pre-sleep protein ingestion with ( $P R O+E X ; n=11)$ and without $(P R O ; n=12)$ prior exercise in older men. Values represent means + SEM. The data were analyzed with a two-way repeated-measures (treatment $x$ time) ANOVA.

Plasma phenylalanine (Figure 4.3A), leucine (Figure 4.3B), tyrosine (Figure 4.3C) concentrations increased over time, with peak concentrations being reached $t=210 \mathrm{~min}$ after protein ingestion, which did not differ between treatments $(P \geq 0.05)$. 


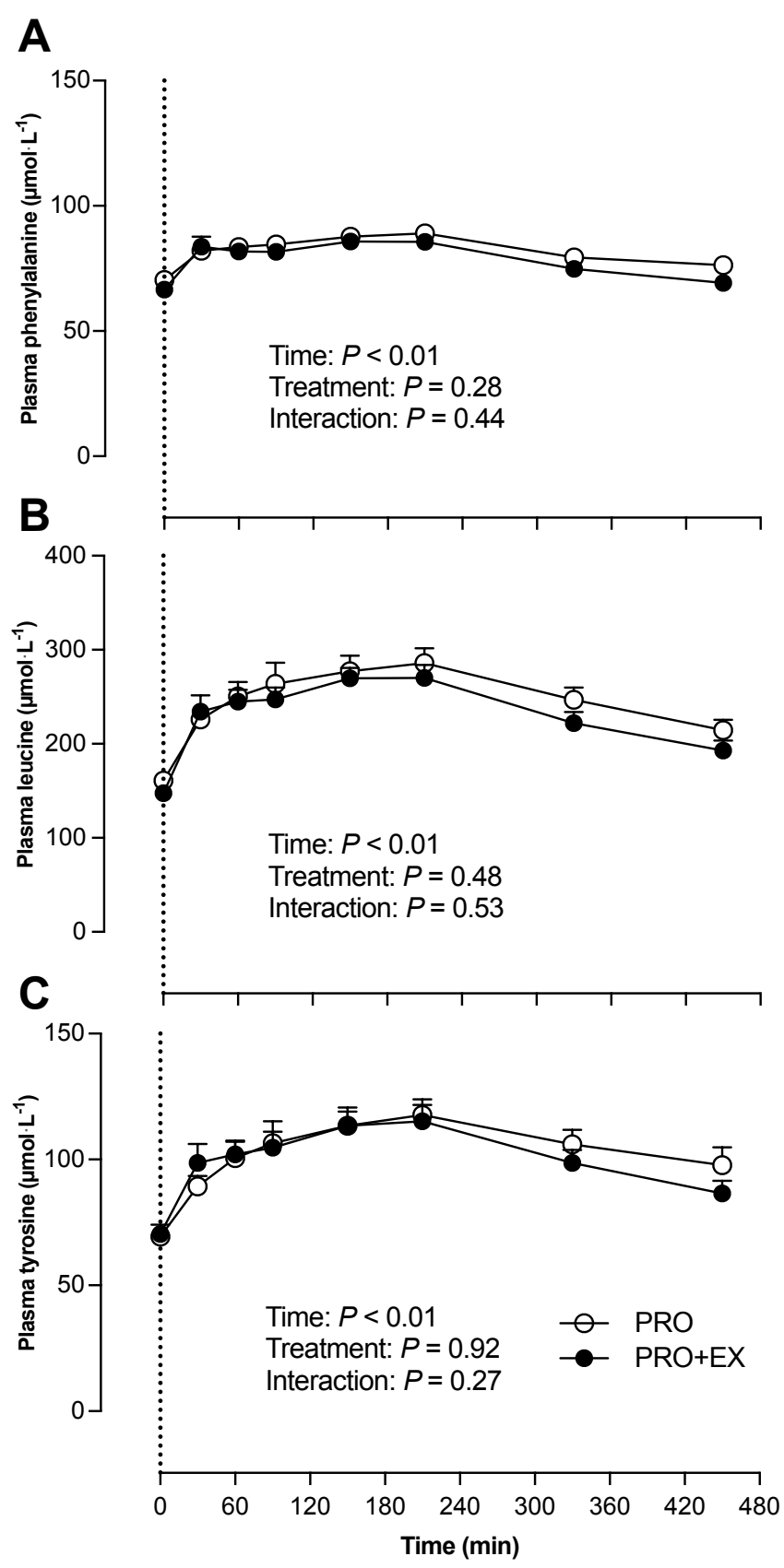

Figure 4.3 Overnight plasma phenylalanine (A), leucine (B) and tyrosine (C) concentrations $\left(\mu \mathrm{mo} \cdot \mathrm{L}^{-1}\right)$ following $40 \mathrm{~g}$ of pre-sleep protein ingestion with $(P R O+E X ; n=11)$ and without $(P R O ; n=12)$ prior exercise in older men. The dotted line represents the ingestion of the beverage. Values represent means + SEM. The data were analyzed with a two-way repeated-measures (treatment $x$ time) ANOVA.

Plasma enrichments from infused (L-[ring- $\left.{ }^{2} \mathrm{H}_{5}\right]$-phenylalanine; Figure 4.4A), infused and ingested $\left(\mathrm{L}-\left[1-{ }^{13} \mathrm{C}\right]\right.$-leucine; Figure 4.4B) and ingested $\left(\mathrm{L}-\left[1-{ }^{13} \mathrm{C}\right]\right.$-phenylalanine; Figure $\left.4.4 \mathrm{C}\right)$ did not differ between treatments before ingesting the protein ( $t=0 \mathrm{~min}, P \geq 0.05$ ). Whereas plasma L-[ring- $\left.{ }^{2} \mathrm{H}_{5}\right]$-phenylalanine enrichments declined following protein ingestion, plasma $\mathrm{L}-\left[1-{ }^{13} \mathrm{C}\right]$-leucine enrichment levels increased before reaching a steady-state for the duration of the trial. After protein ingestion, plasma $\mathrm{L}-\left[1-{ }^{13} \mathrm{C}\right]$-phenylalanine enrichments, originating 


\section{Chapter 4}

from the ingested protein, increased in both groups reaching maximal values at $t=210 \mathrm{~min}$ in PRO and at $t=150 \mathrm{~min}$ in PRO+EX and remained elevated for the duration of the night. A main effect for time was detected across groups $(P<0.05)$, but there were no significant interaction effects for treatment $x$ time.

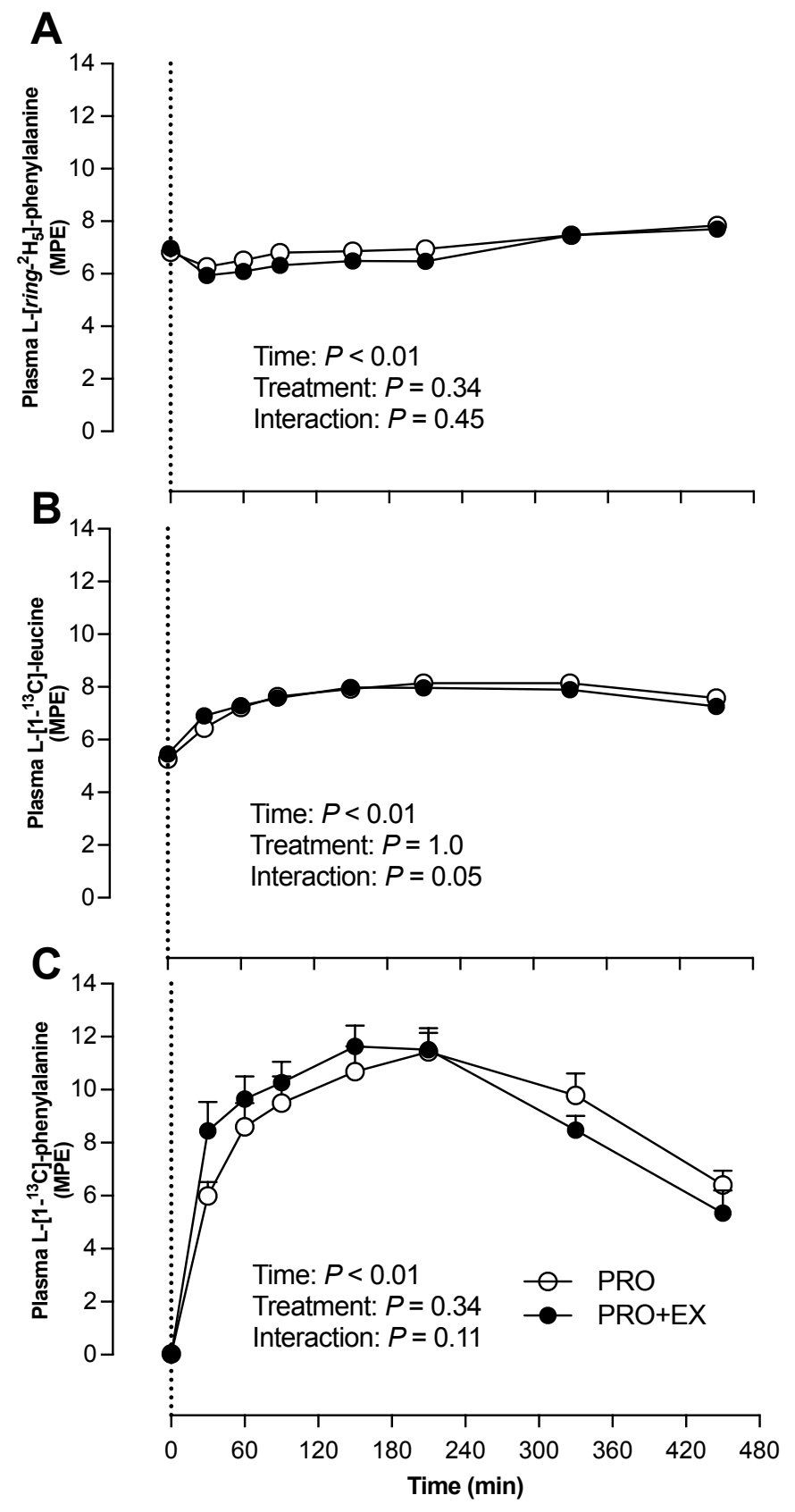

Figure 4.4 Overnight plasma L-[ring- $\left.{ }^{2} \mathrm{H}_{5}\right]$-phenylalanine (A), L- $\left[1-{ }^{13} \mathrm{C}\right]$-phenylalanine (B), L-[1-13 C]-leucine (C) enrichments in mole percent excess (MPE) following $40 \mathrm{~g}$ of pre-sleep protein ingestion with $(P R O+E X ; n=11)$ and without (PRO; $n=12$ ) prior exercise in older men. The dotted line represents the ingestion of the beverage. Values represent means + SEM. Data were analyzed with two-way repeated-measures (treatment $x$ time) ANOVA. 


\section{Whole-body amino acid kinetics}

Exogenous phenylalanine appearance rates (Figure 4.5B) increased following protein ingestion with peak levels being reached at $t=150 \mathrm{~min}$ in the PRO and PRO+EX treatment groups, respectively $(P \geq 0.05)$. As a result of increased exogenous rates of appearance, endogenous phenylalanine appearance rates (Figure $4.5 \mathrm{C}$ ) declined following protein ingestion in both groups, with no differences detected $(P \geq 0.05)$. The ingested dietary protein-bound phenylalanine that appeared in the circulation over the entire $7.5 \mathrm{~h}$ post prandial period did not differ between groups $(P \geq 0.05)$ and averaged $54 \pm 2 \%$ overall.
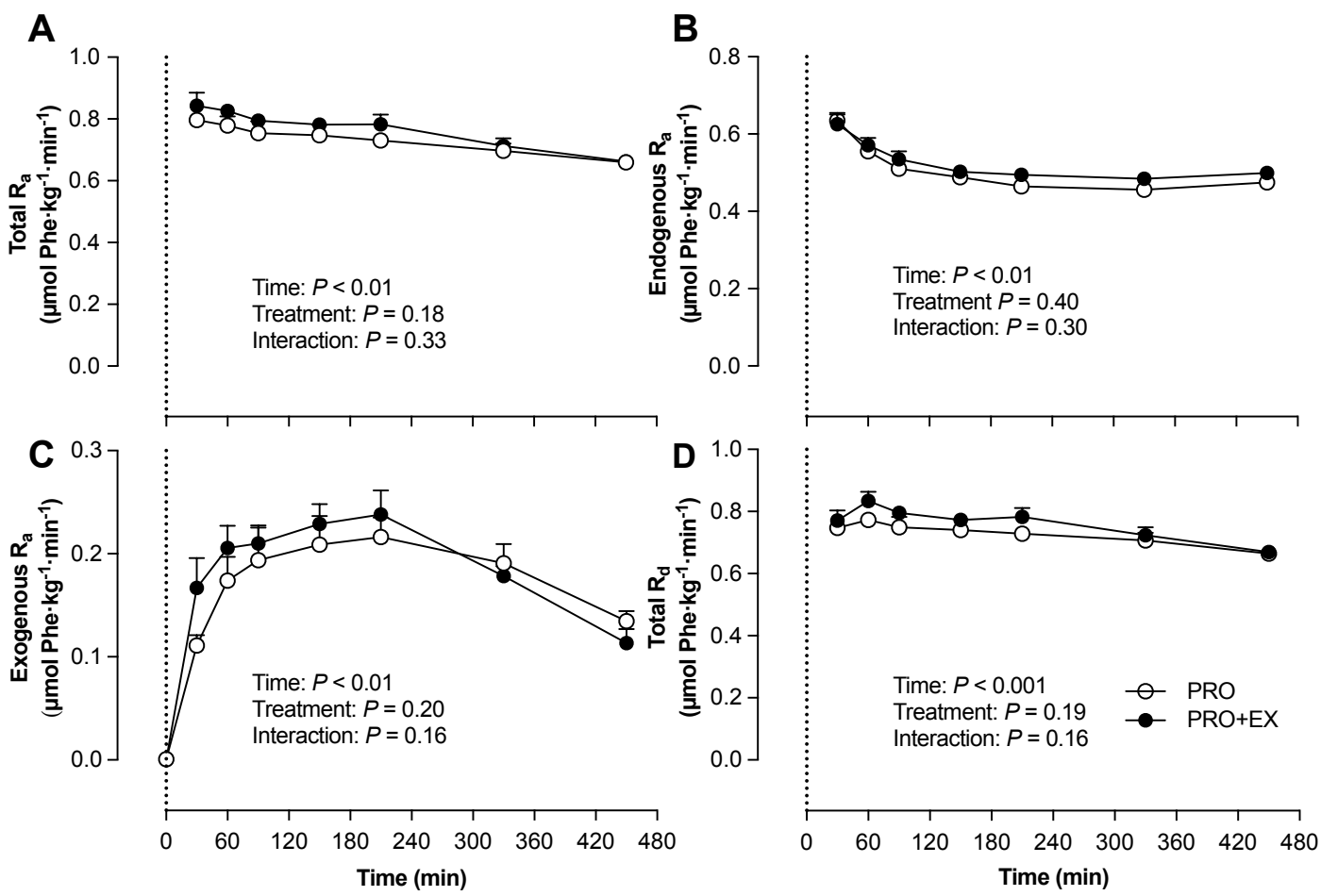

Figure 4.5 Total phenylalanine rate of appearance $(R a)(A)$, Exogenous phenylalanine Ra (B), Endogenous phenylalanine $R a(C)$, and total phenylalanine rate of disappearance $\left(R_{d}\right)(D)$ following $40 \mathrm{~g}$ of pre-sleep protein ingestion with $(P R O+E X ; n=11)$ and without $(P R O ; n=12)$ prior exercise in older men. Values represent means + SEM. Data were analyzed with two-way repeated-measures (treatment $x$ time) ANOVA.

Protein ingestion prior to sleep resulted in positive overnight whole-body protein net balance (Figure 4.6), with no differences observed between treatment groups $(P \geq 0.05)$. Furthermore, physical activity did not appear to further influence any other parameters of whole-body protein metabolism: synthesis rates $(P \geq 0.05)$, breakdown rates $(P \geq 0.05)$, oxidation rates $(P \geq 0.05)$. 


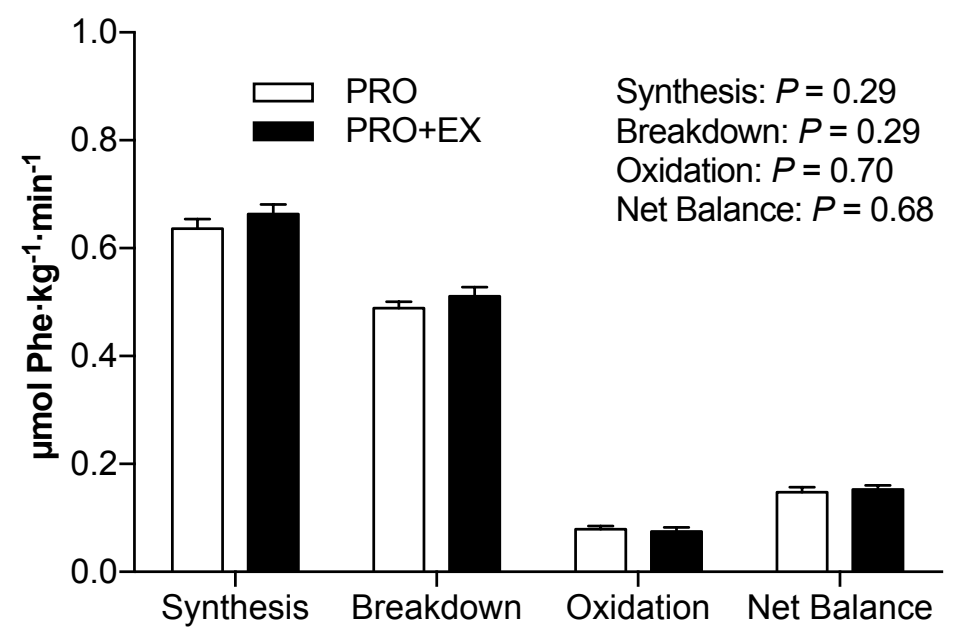

Figure 4.6 Calculated rates of whole-body protein synthesis, breakdown, oxidation and net protein balance (expressed in $\mu \mathrm{mol} \cdot$ phenylalanine $\left.\cdot \mathrm{kg}^{-1} \cdot \mathrm{min}^{-1}\right)$ following $40 \mathrm{~g}$ of pre-sleep protein ingestion with $(P R O+E X ; n=$ $11)$ and without $(P R O ; n=12)$ prior exercise in older men. Values represent means + SEM. Data were analyzed with a Student's unpaired t-test. No significant differences were detected.

\section{Myofibrillar fractional synthesis rates and protein-bound enrichments}

Myofibrillar L-[ring- $\left.{ }^{2} \mathrm{H}_{5}\right]$-phenylalanine and $\mathrm{L}-\left[1-{ }^{13} \mathrm{C}\right]$-leucine enrichments were measured in muscle samples collected immediately before protein ingestion and immediately after waking. The post-prandial increase in myofibrillar protein bound $\mathrm{L}-\left[\mathrm{ring}_{-}{ }^{2} \mathrm{H}_{5}\right.$ ]-phenylalanine and $L-\left[1-{ }^{13} \mathrm{C}\right]$-leucine enrichments averaged $0.0230 \pm 0.0015$ vs $0.0294 \pm 0.0010$ and 0.0334 \pm 0.0020 vs $0.0417 \pm 0.0018 \mathrm{MPE}$ in $\mathrm{PRO}$ vs $\mathrm{PRO}+\mathrm{EX}$, respectively $(P<0.05)$. Myofibrillar protein FSR (in \% $\mathrm{h}^{-1}$ ) was calculated using L-[ring- $\left.{ }^{2} \mathrm{H}_{5}\right]$-phenylalanine plasma (Figure 4.7A) and muscle protein-bound enrichments and using $\mathrm{L}-\left[1{ }^{13} \mathrm{C}\right]$-leucine (Figure 4.7B) plasma and muscle protein-bound enrichments. $\mathrm{PRO}+\mathrm{EX}$ resulted in greater stimulation of overnight myofibrillar FSR compared to PRO calculated based upon L-[ring- $\left.{ }^{2} \mathrm{H}_{5}\right]$-phenylalanine $(P<$ $0.05)$ as well as $L-\left[1-{ }^{13} \mathrm{C}\right]$-leucine $(P<0.05)$. Overnight FSR was $31 \%$ and $27 \%$ higher in the $\mathrm{PRO}+\mathrm{EX}$ compared with the PRO treatment group, based upon $\mathrm{L}-\left[\right.$ ring- $\left.^{2} \mathrm{H}_{5}\right]$-phenylalanine and L-[1-13 C]-leucine infusion, respectively. Myofibrillar L-[1- $\left.{ }^{13} \mathrm{C}\right]$-phenylalanine (Figure 4.8) protein-bound enrichment (MPE) was $28 \%$ higher following the ingestion of intrinsically L$\left[1-{ }^{13} \mathrm{C}\right]$-phenylalanine labeled protein in PRO+EX vs PRO $(P<0.05)$. 
A

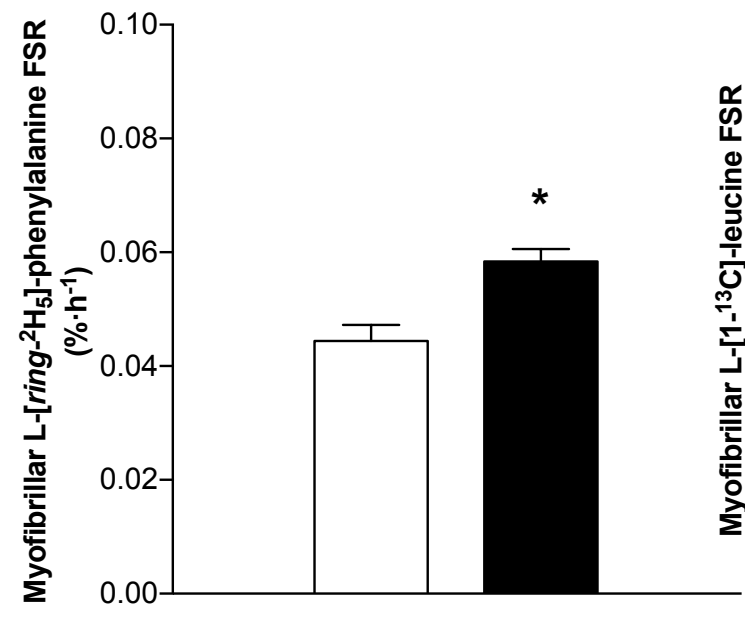

B

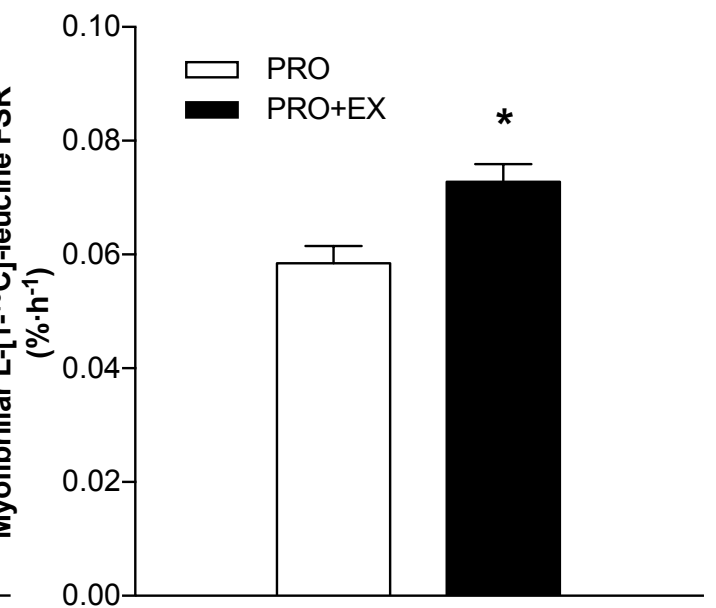

Figure 4.7 Overnight myofibrillar protein fractional synthetic rates (FSR in $\% \cdot h^{-1}$ ) following $40 \mathrm{~g}$ of pre-sleep protein ingestion with $(P R O+E X, n=11)$ or without $(P R O, n=12)$ prior exercise as calculated using L-[ring$\left.{ }^{2} \mathrm{H}_{5}\right]$-phenylalanine $(\mathrm{A})$ or $\mathrm{L}-\left[1-{ }^{13} \mathrm{C}\right]$-leucine $(B)$ as tracer. Values represent means $+\mathrm{SEM}$. Data were analyzed with a Student's unpaired t-test. *Significantly different from $P R O, P<0.01$.

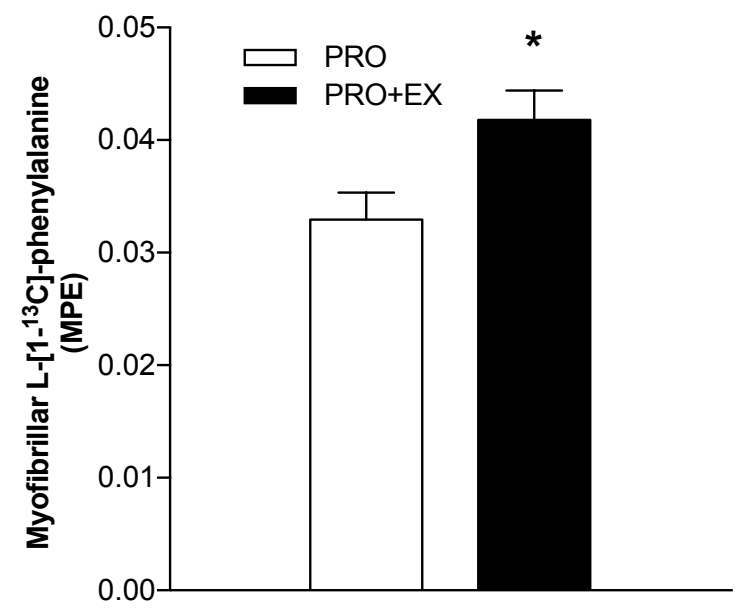

Figure 4.8 Overnight $\mathrm{L}-\left[1-{ }^{13} \mathrm{C}\right]$-phenylalanine incorporation into myofibrillar protein following ingestion of 40 $g$ intrinsically $L-\left[1-{ }^{13} \mathrm{C}\right]$-phenylalanine-labeled protein prior to sleep with (PRO+EX) or without (PRO) prior exercise. Values represent means+ SEM. Data were analyzed with a Student's unpaired t-test. *Significantly different from $P R O, P<0.01$. 
Chapter 4

Sleep data

Sleep onset latency and sleep efficiency data collected during the overnight sleep test are displayed in Table 4.2. Sleep onset latency, a measure of the time taken to fall asleep, was 06:12 \pm 02:04 vs 07:00 \pm 02:09 (min:sec) in the PRO vs PRO+EX treatment groups, respectively

$(P \geq 0.05)$. The amount of time that subjects spent awake or in light sleep throughout the sleeping period was 01:00:12 \pm 00:11:28 vs 00:38:15 \pm 00:06:45 (min:sec) in PRO and PRO+EX, respectively $(P \geq 0.05)$. Sleep efficiency, a measure of sleep quality throughout the night, also did not differ between treatment groups $(81.4 \pm 3.1$ vs $82.3 \pm 8.7 \%$ in PRO and $\mathrm{PRO}+\mathrm{EX}$, respectively, $P \geq 0.05)$.

Table 4.2 Sleep quality data collected with wrist activity monitors worn during sleep ${ }^{1}$

\begin{tabular}{lccc}
\hline & & & \\
& PRO $(\boldsymbol{n}=\mathbf{1 0})$ & PRO+EX $(\boldsymbol{n}=\mathbf{8})$ & $\boldsymbol{P}$ \\
\hline Bed Time, hh:mm & $23: 55$ & $23: 55$ & 0.99 \\
Get up Time, hh:mm & $7: 01$ & $7: 04$ & 0.64 \\
Sleep onset latency, mm:ss & $06: 12 \pm 02: 04$ & $07: 00 \pm 02: 09$ & 0.81 \\
Sleep Duration, hh:mm & $05: 46 \pm 00: 14$ & $05: 53 \pm 00: 37$ & 0.75 \\
Time Awake/Light Sleep, hh:mm & $01: 00 \pm 00: 11$ & $00: 38 \pm 00: 06$ & 0.13 \\
Sleep Efficiency, \% & $81.4 \pm 3.1$ & $82.3 \pm 8.7$ & 0.83 \\
Wake Bouts & $17 \pm 2$ & $12 \pm 2$ & 0.09 \\
\hline
\end{tabular}

${ }^{1}$ Values are expressed as means \pm SEM. PRO treatment, $n=10 ; P R O+E X$ treatment, $n=8$. No significant differences were observed between treatment groups. 


\section{Discussion}

In the present study, we assessed whether physical activity performed in the evening after a full day of standardized dietary intake and physical activity could augment the overnight muscle protein synthetic response to pre-sleep protein ingestion in older men. We observed that protein ingested prior to sleep was normally digested and absorbed, with $54 \pm 2 \%$ of the ingested protein-derived amino acids appearing in the circulation throughout overnight sleep. Myofibrillar protein synthesis rates during overnight sleep were substantially higher when physical activity was performed earlier that evening, with $28 \%$ more of the pre-sleep dietary protein-derived amino acids being directed towards de novo overnight muscle protein synthesis.

We administered a primed, continuous intravenous infusion of $\mathrm{L}-\left[\mathrm{ring}-{ }^{2} \mathrm{H}_{5}\right]$-phenylalanine and $\mathrm{L}-\left[1-{ }^{13} \mathrm{C}\right]$-leucine throughout the night and provided all participants with $40 \mathrm{~g}$ intrinsically $\mathrm{L}-$ $\left[1-{ }^{13} \mathrm{C}\right]$-phenylalanine-labeled casein protein prior to sleep. With this experimental protocol, we were able to assess overnight protein digestion and amino acid absorption kinetics, whole-body protein metabolism, myofibrillar protein synthesis, and the specific utilization of dietary protein-derived amino acids for de novo muscle protein synthesis $(5,11)$. Upon protein ingestion, we observed a rapid rise in circulating plasma amino acids (Figure 4.3) and $\mathrm{L}-\left[1-{ }^{13} \mathrm{C}\right]$-phenylalanine enrichments (Figure 4.4C), demonstrating proper protein digestion and subsequent amino acid absorption during sleep. Exogenous dietary proteinderived phenylalanine appearance rates remained elevated throughout overnight sleep (Figure $4.5 \mathrm{C}$ ). Over the entire $7.5 \mathrm{~h}$ overnight period, $53 \pm 2 \%$ of the ingested proteinderived amino acids appeared in the circulation, with the other $47 \pm 2 \%$ of the proteinderived amino acid being retained in the gut to support turnover of splanchnic tissues. These data are in line with previous work quantifying first pass amino acid extraction conducted during the day time (25-27), and extend upon these findings with the observation that physical activity performed earlier during the evening does not modulate overnight protein digestion and amino acid absorption following pre-sleep protein ingestion.

Protein ingestion prior to sleep has previously been shown to improve whole-body protein synthesis and reduce whole-body protein breakdown allowing for a positive net protein balance during overnight sleep $(12,29)$. In the present study, we confirm our previous findings by showing that pre-sleep protein ingestion resulted in a (more) positive overnight whole-body protein balance (Figure 4.6). Physical activity performed earlier that day did not seem to have a substantial impact on overnight whole-body protein synthesis, breakdown, amino acid oxidation or net balance (Figure 4.6). However, it should be noted that wholebody protein metabolism does not necessarily reflect skeletal muscle protein turnover. Because we aimed to assess the impact of physical activity on the overnight muscle protein synthetic response, we collected muscle biopsies immediately before and after overnight sleep. 
With the present amino acid tracer methodology, we were able to assess rates of muscle protein synthesis under steady-state $\left(\mathrm{L}-\left[1-{ }^{13} \mathrm{C}\right]-\right.$ leucine $)$ and non-steady state (L-[ring- $\left.{ }^{2} \mathrm{H}_{5}\right]$ phenylalanine) pre-cursor conditions (5). As hypothesized, myofibrillar protein synthesis rates were $31 \%\left(\mathrm{~L}-\left[\right.\right.$ ring $\left._{-}{ }^{2} \mathrm{H}_{5}\right]$-phenylalanine, Figure 4.7A) and $27 \%\left(\mathrm{~L}-\left[1-{ }^{13} \mathrm{C}\right]\right.$-leucine, Figure 4.7B) higher in the PRO+EX compared with the PRO treatment. These findings extend upon our previous work showing that administration of $40 \mathrm{~g}$ protein prior to sleep increases overnight muscle protein synthesis rates when compared to a placebo (12). Furthermore, these findings are in line with previous work investigating the impact of physical activity or exercise on the post-prandial muscle protein synthetic response to protein or meal feeding following an overnight fast, showing that physical activity further augments the post-prandial rise in muscle protein synthesis rate by approximately $25 \%(27,36)$. This supports the concept that physical activity increases the sensitivity of skeletal muscle tissue to the anabolic properties of protein ingestion and that this response may extend into overnight sleep. In the present study, we combined continuous infusions of $\mathrm{L}-\left[\right.$ ring- $\left.{ }^{2} \mathrm{H}_{5}\right]$-phenylalanine and $\mathrm{L}-\left[1-{ }^{13} \mathrm{C}\right]$-leucine with the ingestion of intrinsically $\mathrm{L}-\left[1-{ }^{13} \mathrm{C}\right]$-phenylalanine labeled protein $(5,32)$. Because this specifically produced protein has a high enrichment ( $>35 \%$ ), we are able to directly assess the metabolic fate of the dietary protein-derived amino acids. Here, we demonstrate that the ingested protein was utilized for de novo skeletal muscle protein synthesis throughout overnight sleep (Figure 4.8). Substantially more (28\%) of the dietary protein-derived phenylalanine was incorporated into skeletal muscle protein when physical activity was performed earlier in the day. Therefore, physical activity throughout the day increases the efficiency by which dietary protein-derived amino acids provided prior to sleep are directed towards overnight de novo muscle protein synthesis. Consequently, the combination of physical activity or exercise with pre-sleep protein ingestion can augment the overnight muscle protein synthetic response and increase the efficacy by which pre-sleep protein supplementation may help to preserve muscle mass and strength in the older population. In support, we recently reported greater gains in skeletal muscle mass and strength following 3 months of evening resistance-type exercise training in young males when subjects were provided with additional protein prior to sleep (30).

It has been well-established that the anabolic response to protein ingestion is impaired in older $(6,8,34)$ and/or more clinically compromised populations $(21,33-35)$. Previous work from our group $(25)$ as well as others $(38,39)$ has shown that increasing protein intake can compensate for anabolic resistance. However, ingesting larger protein doses may not be feasible or practical in all older and/or clinically compromised populations. Protein ingestion prior to sleep may represent an effective nutritional strategy to preserve muscle mass by stimulating and supporting muscle protein accretion during overnight sleep. The current data extend upon previous observations and are the first to show that physical activity performed throughout the day increases the efficiency by which dietary protein ingested prior to sleep is directed towards de novo muscle protein synthesis in older individuals. Therefore, older individuals who are unable to ingest large amounts of protein can still 
benefit from ingesting smaller amounts of protein $(<40 \mathrm{~g})$ before sleep by performing physical activity beforehand. As such, a physical activity program should be implemented in combination with pre-sleep protein ingestion to benefit from the synergy between physical activity and protein to increase overnight muscle protein accretion in order to support healthy aging.

In conclusion, physical activity performed in the evening augments the overnight muscle protein synthetic response to pre-sleep protein ingestion and allows more of the ingested protein-derived amino acids to be used for de novo muscle protein synthesis during overnight sleep in older men. Combining pre-sleep protein ingestion with physical activity may aid in preserving skeletal muscle mass and, as such, support healthy aging. 


\section{References}

1. Baumgartner RN, Waters DL, Gallagher D, Morley JE, Garry PJ. Predictors of skeletal muscle mass in elderly men and women. Mech Ageing Dev 107: 123-136, 1999.

2. Bergström J, Hultman E. A study of the glycogen metabolism during exercise in man. Scand J Clin Lab Invest 19: 218-228, 1967.

3. Biolo G, Maggi SP, Williams BD, Tipton KD, Wolfe RR. Increased rates of muscle protein turnover and amino acid transport after resistance exercise in humans. Am J Physiol 268: E514-20, 1995.

4. Boirie Y, Gachon P, Corny S, Fauquant J, Maubois JL, Beaufrere B. Acute postprandial changes in leucine metabolism as assessed with an intrinsically labeled milk protein. Am J Physiol 271: E1083-91, 1996.

5. Burd NA, Cermak NM, Kouw IWK, Gorissen SH, Gijsen AP, van Loon LJC. The use of doubly labeled milk protein to measure postprandial muscle protein synthesis rates in vivo in humans. $J$ Appl Physiol 117: 1363-1370, 2014.

6. Burd NA, Gorissen SH, van Loon LJC. Anabolic resistance of muscle protein synthesis with aging. Exerc Sport Sci Rev 41: 169-173, 2013.

7. Buysse DJ, Reynolds CF, Monk TH, Berman SR, Kupfer DJ. The Pittsburgh Sleep Quality Index: a new instrument for psychiatric practice and research. Psychiatry Res 28: 193-213, 1989.

8. Cuthbertson D, Smith K, Babraj J, Leese G, Waddell T, Atherton P, Wackerhage H, Taylor PM, Rennie MJ. Anabolic signaling deficits underlie amino acid resistance of wasting, aging muscle. FASEB J 19: 422424, 2005.

9. Dangin M, Guillet C, Garcia-Rodenas C, Gachon P, Bouteloup-Demange C, Reiffers-Magnani K Fauquant $\mathrm{J}$, Ballèvre $\mathrm{O}$, Beaufrère $\mathrm{B}$. The rate of protein digestion affects protein gain differently during aging in humans. J Physiol 549: 635-644, 2003.

10. Genuth S, Alberti KGMM, Bennett P, Buse J, Defronzo R, Kahn R, Kitzmiller J, Knowler WC, Lebovitz H, Lernmark A, Nathan D, Palmer J, Rizza R, Saudek C, Shaw J, Steffes M, Stern M, Tuomilehto J, Zimmet P, Expert Committee on the Diagnosis and Classification of Diabetes Mellitus. Follow-up Report on the Diagnosis of Diabetes Mellitus. Diabetes care. 2003, p. 3160-3167.

11. Gorissen SHM, Burd NA, Hamer HM, Gijsen AP, Groen BB, van Loon LJC. Carbohydrate coingestion delays dietary protein digestion and absorption but does not modulate postprandial muscle protein accretion. J Clin Endocrinol Metab 99: 2250-2258, 2014.

12. Groen BBL, Res PT, Pennings B, Hertle E, Senden JMG, Saris WHM, van Loon LJC. Intragastric protein administration stimulates overnight muscle protein synthesis in elderly men. Am J Physiol Endocrinol Metab 302: E52-60, 2012.

13. Katsanos CS, Kobayashi H, Sheffield-Moore M, Aarsland A, Wolfe RR. Aging is associated with diminished accretion of muscle proteins after the ingestion of a small bolus of essential amino acids. Am J Clin Nutr 82: 1065-1073, 2005.

14. Katsanos CS, Kobayashi H, Sheffield-Moore M, Aarsland A, Wolfe RR. A high proportion of leucine is required for optimal stimulation of the rate of muscle protein synthesis by essential amino acids in the elderly. Am J Physiol Endocrinol Metab 291: E381-7, 2006.

15. Koopman R, Crombach N, Gijsen AP, Walrand S, Fauquant J, Kies AK, Lemosquet S, Saris WHM, Boirie Y, van Loon LJC. Ingestion of a protein hydrolysate is accompanied by an accelerated in vivo digestion and absorption rate when compared with its intact protein. Am J Clin Nutr 90: 106-115, 2009.

16. Mamerow MM, Mettler JA, English KL, Casperson SL, Arentson-Lantz E, Sheffield-Moore M, Layman DK, Paddon-Jones D. Dietary protein distribution positively influences $24-h$ muscle protein synthesis in healthy adults. J Nutr 144: 876-880, 2014.

17. Mayhew JL, Prinster JL, Ware JS, Zimmer DL, Arabas JR, Bemben MG. Muscular endurance repetitions to predict bench press strength in men of different training levels. J Sports Med Phys Fitness 35: 108113, 1995.

18. Mitchell WK, Williams J, Atherton P, Larvin M, Lund J, Narici M. Sarcopenia, dynapenia, and the impact of advancing age on human skeletal muscle size and strength; a quantitative review. Front Physiol 3: 260, 2012.

19. Moore DR, Tang JE, Burd NA, Rerecich T, Tarnopolsky MA, Phillips SM. Differential stimulation of myofibrillar and sarcoplasmic protein synthesis with protein ingestion at rest and after resistance exercise. J Physiol 587: 897-904, 2009. 
20. Murphy $\mathrm{CH}$, Churchward-Venne TA, Mitchell CJ, Kolar NM, Kassis A, Karagounis LG, Burke LM, Hawley JA, Phillips SM. Hypoenergetic diet-induced reductions in myofibrillar protein synthesis are restored with resistance training and balanced daily protein ingestion in older men. Am J Physiol Endocrinol Metab 308: E734-43, 2015.

21. Murton AJ, Marimuthu K, Mallinson JE, Selby AL, Smith K, Rennie MJ, Greenhaff PL. Obesity Appears to Be Associated With Altered Muscle Protein Synthetic and Breakdown Responses to Increased Nutrient Delivery in Older Men, but Not Reduced Muscle Mass or Contractile Function. Diabetes 64: 3160-3171, 2015.

22. Paddon-Jones D, Sheffield-Moore M, Katsanos CS, Zhang X-J, Wolfe RR. Differential stimulation of muscle protein synthesis in elderly humans following isocaloric ingestion of amino acids or whey protein. Exp Gerontol 41: 215-219, 2006.

23. Paddon-Jones D, Sheffield-Moore M, Zhang X-J, Volpi E, Wolf SE, Aarsland A, Ferrando AA, Wolfe RR. Amino acid ingestion improves muscle protein synthesis in the young and elderly. Am J Physiol Endocrinol Metab 286: E321-8, 2004.

24. Pennings B, Boirie $Y$, Senden JMG, Gijsen AP, Kuipers H, van Loon LJC. Whey protein stimulates postprandial muscle protein accretion more effectively than do casein and casein hydrolysate in older men. Am J Clin Nutr 93: 997-1005, 2011.

25. Pennings B, Groen B, de Lange A, Gijsen AP, Zorenc AH, Senden JMG, van Loon LJC. Amino acid absorption and subsequent muscle protein accretion following graded intakes of whey protein in elderly men. Am J Physiol Endocrinol Metab 302: E992-9, 2012.

26. Pennings B, Groen BBL, van Dijk J-W, de Lange A, Kiskini A, Kuklinski M, Senden JMG, van Loon LJC. Minced beef is more rapidly digested and absorbed than beef steak, resulting in greater postprandial protein retention in older men. Am J Clin Nutr 98: 121-128, 2013.

27. Pennings B, Koopman R, Beelen M, Senden JMG, Saris WHM, van Loon LJC. Exercising before protein intake allows for greater use of dietary protein-derived amino acids for de novo muscle protein synthesis in both young and elderly men. Am J Clin Nutr 93: 322-331, 2011.

28. Phillips SM, Tipton KD, Aarsland A, Wolf SE, Wolfe RR. Mixed muscle protein synthesis and breakdown after resistance exercise in humans. Am J Physiol 273: E99-107, 1997.

29. Res PT, Groen B, Pennings B, Beelen M, Wallis GA, Gijsen AP, Senden JMG, van Loon LJC. Protein ingestion before sleep improves postexercise overnight recovery. Med Sci Sports Exerc 44: 1560-1569, 2012.

30. Snijders T, Res PT, Smeets JSJ, van Vliet S, van Kranenburg J, Maase K, Kies AK, Verdijk LB, van Loon LJC. Protein Ingestion before Sleep Increases Muscle Mass and Strength Gains during Prolonged Resistance-Type Exercise Training in Healthy Young Men. J Nutr 145: 1178-1184, 2015.

31. Staples AW, Burd NA, West DWD, Currie KD, Atherton PJ, Moore DR, Rennie MJ, MacDonald MJ, Baker SK, Phillips SM. Carbohydrate does not augment exercise-induced protein accretion versus protein alone. Med Sci Sports Exerc 43: 1154-1161, 2011.

32. van Loon LJC, Boirie $Y$, Gijsen AP, Fauquant J, de Roos AL, Kies AK, Lemosquet S, Saris WHM, Koopman $\mathbf{R}$. The production of intrinsically labeled milk protein provides a functional tool for human nutrition research. J Dairy Sci 92: 4812-4822, 2009.

33. Wall BT, Dirks ML, van Loon LJC. Skeletal muscle atrophy during short-term disuse: implications for agerelated sarcopenia. Ageing Res Rev 12: 898-906, 2013.

34. Wall BT, Gorissen SH, Pennings B, Koopman R, Groen BBL, Verdijk LB, van Loon LJC. Aging Is Accompanied by a Blunted Muscle Protein Synthetic Response to Protein Ingestion. PLOS ONE 10: e0140903, 2015.

35. Williams JP, Phillips BE, Smith K, Atherton PJ, Rankin D, Selby AL, Liptrot S, Lund J, Larvin M, Rennie MJ. Effect of tumor burden and subsequent surgical resection on skeletal muscle mass and protein turnover in colorectal cancer patients. Am J Clin Nutr 96: 1064-1070, 2012.

36. Witard OC, Tieland M, Beelen M, Tipton KD, van Loon LJC, Koopman R. Resistance exercise increases postprandial muscle protein synthesis in humans. Med Sci Sports Exerc 41: 144-154, 2009.

37. Wolfe RR, Chinkes DL. Isotope tracers in metabolic research: principles and practice of kinetic analysis. 2005.

38. Yang Y, Breen L, Burd NA, Hector AJ, Churchward-Venne TA, Josse AR, Tarnopolsky MA, Phillips SM. Resistance exercise enhances myofibrillar protein synthesis with graded intakes of whey protein in older men. Br J Nutr 108: 1780-1788, 2012. 


\section{Chapter 4}

39. Yang Y, Churchward-Venne TA, Burd NA, Breen L, Tarnopolsky MA, Phillips SM. Myofibrillar protein synthesis following ingestion of soy protein isolate at rest and after resistance exercise in elderly men. Nutr Metab 9: 57, 2012. 


\section{Chapter 5}

Body position modulates gastric emptying and affects the postprandial rise in plasma amino acid concentrations following protein ingestion in humans

Andrew M. Holwerda, Kaatje Lenaerts, Jörgen Bierau and Luc J.C. van Loon

Nutrients, 8(4), 221. 2016. 
Chapter 5

\section{Abstract}

Background Dietary protein digestion and amino acid absorption kinetics determine the post-prandial muscle protein synthetic response. Body position may affect gastrointestinal function and modulate the post-prandial rise in plasma amino acid availability.

Objective We aimed to assess the impact of body position on gastric emptying rate and the post-prandial rise in plasma amino acid concentrations following ingestion of a single, meal-like amount of protein.

Methods In a randomized, cross-over design, eight healthy males $(25 \pm 2$ y, $23.9 \pm 0.8$ $\mathrm{kg} \cdot \mathrm{m}^{-2}$ ) ingested $22 \mathrm{~g}$ protein and $1.5 \mathrm{~g}$ paracetamol (acetaminophen) in an upright seated position (control) and in a $-20^{\circ}$ head-down tilted position (inversion). Blood samples were collected during a $240 \mathrm{~min}$ post-prandial period and analyzed for paracetamol and plasma amino acid concentrations to assess gastric emptying rate and post-prandial amino acid availability, respectively.

Results Peak plasma leucine concentrations were lower in the inversion compared with the control treatment (177 \pm 15 vs $\left.236 \pm 15 \mathrm{mmol} \cdot \mathrm{L}^{-1}, P<0.05\right)$, which was accompanied by a lower plasma essential amino acid (EAA) response over $240 \min (31,956 \pm 6441$ vs 50,351 $\pm 4015 \mathrm{AU} ; P<0.05)$. Peak plasma paracetamol concentrations were lower in the inversion vs control treatment (5.8 \pm 1.1 vs $\left.10.0 \pm 0.6 \mathrm{mg} \cdot \mathrm{L}^{-1}, P<0.05\right)$.

Conclusions Gastric emptying rate and post-prandial plasma amino acid availability are significantly decreased after protein ingestion in a head-down tilted position. Therefore, upright body positioning should be considered when aiming to augment post-prandial muscle protein accretion in both health and disease. 


\section{Introduction}

Ingestion of dietary protein increases muscle protein synthesis rates $(5,35,45,53,54)$. This increase in muscle protein synthesis has been attributed to the post-prandial rise in circulating (essential) amino acid concentrations, with leucine being of particular relevance $(9,15,18,50)$. The post-prandial muscle protein synthetic response is regulated on multiple levels, ranging from protein digestion and amino acid absorption $(3,29)$, post-prandial insulin release and the subsequent increase in muscle perfusion (40), amino acid uptake in muscle (12), activation of anabolic signaling pathways $(9,20,31)$, and subsequent myofibrillar protein synthesis $(5,35,45,53,54)$.

The post-prandial muscle protein synthetic response can be modulated by changing the type $(29,37)$, amount $(38,42,53,54)$ and timing $(33,34)$ of protein ingestion. Differences in the anabolic properties of various proteins have been attributed to their specific protein digestion and amino acid absorption kinetics (6) as well as their amino acid composition (7). Previous work from our group (37) as well as others $(4,10,11,14,26,41,46,54)$ has shown that the ingestion of more rapidly digestible protein, such as whey, results in a greater postprandial rise in circulating amino acid concentrations, thereby further increasing whole-body and/or muscle protein synthesis rates when compared with the ingestion of a more slowly digestible protein, such as intact casein. However, whey and casein do not only differ in their protein digestion and absorption kinetics, but also in their amino acid composition, with whey containing more leucine $(3,10,46)$.

To define the impact of dietary protein digestion and absorption kinetics per se on postprandial protein handling we assessed protein digestion and amino acid absorption and post-prandial muscle protein synthesis rates following the ingestion of intact micellar casein in comparison with its hydrolyzed form $(29,37)$. Ingestion of the more rapidly digestible casein hydrolysate resulted in a more rapid post-prandial rise in circulating amino acids, greater post-prandial dietary protein-derived amino acid availability and $\sim 30 \%$ higher postprandial muscle protein synthesis rates when compared to ingestion of intact casein (29). These findings confirmed the importance of the rate of digestion and amino acid absorption in stimulating post-prandial muscle protein synthesis rates. These findings sparked research investigating various factors that may modulate post-prandial protein handling, which include the type of protein $(10,11,37)$, the matrix in which the protein is consumed $(8,32$, $43)$, the macronutrient composition of a protein-rich meal $(23,44)$ as well as food preparation $(2,19,39)$ and mastication $(16)$. We speculated that protein digestion and absorption might also be modulated by a factor as simple as body position (i.e., sitting upright or lying down). Digestive modulation through changes in body position may be of particular interest since a blunted muscle protein synthesis response to feeding is typically observed in settings where patients are subjected to prolonged supine rest or in the absence of gravity (17).

In the present study, we tested our hypothesis that changes in body position strongly modulate gastric emptying rate and affect the post-prandial rise in amino acid 


\section{Chapter 5}

concentrations in vivo in humans. To test this hypothesis, 8 young males were selected to participate in this randomized, cross-over study with two treatments. We assessed gastric emptying rate and the post-prandial rise in circulating amino acids following ingestion of a single, meal-like amount of protein while maintaining a conventional, upright seated body position and while laying supine at a $-20^{\circ}$ head-down tilted position. This study is the first proof-of-principle study to show that gastric emptying rate is reduced and post-prandial plasma amino acid responses are attenuated when food is ingested in a partly inverted versus upright body position. 


\section{Materials and methods}

\section{Subjects}

A total of 8 healthy young males $\left(25 \pm 2 \mathrm{y}, 23.9 \pm 0.8 \mathrm{~kg} \cdot \mathrm{m}^{-2}\right)$ were recruited to participate in the study. All subjects were instructed to refrain from any exhaustive physical activity and alcohol consumption for two days prior to each trial. Subjects remained fasted from $2200 \mathrm{~h}$ in the evening before each test. This study is part of a larger project (Netherlands Trial Register, NTR5027) that was approved by the Medical Ethical Committee of the Maastricht University Medical Centre, The Netherlands (METC 14-3-052) and conformed to standards for the use of human subjects in research as outlined in the seventh revision of the Declaration of Helsinki (Brazil, 2013).

\section{Experimental Protocol}

This randomized, cross-over study compared the effect of body position on gastric emptying rate and plasma amino acid availability after protein ingestion. In a proof-of-principle approach, we chose to assess potential differences in body position by comparing an upright seated body position with a moderately inverted body position. Therefore, subjects consumed the protein bolus in an upright seated position (control) and in an $-20^{\circ}$ head-down tilted position (inversion). On the test days, participants reported to the lab in a fasted state and had one Teflon catheter inserted into the antecubital vein of the right arm. A background blood sample was collected and blood pressure and heart rate were measured before subjects were positioned in either the control or inversion position, completed in a randomized order. For the control treatment, subjects sat in a standardized, stationary chair and were instructed to hold their lower back against the back support of the chair. Subjects were supervised throughout the test day and were constantly reminded to maintain the upright posture. For the inversion treatment, subjects were secured with shoulder and waist straps onto a rotatable bed (Confidence Inversion Table, Confidence Fitness, UK) for the duration of the test. Once secured, the table was rotated to an angle of $-20^{\circ}$ head-down tilt from horizontal, confirmed using an electronic level. Subjects acclimatized to each body position for 30 min after which a baseline blood sample was drawn and blood pressure and heart rate were measured. Following the baseline blood draw, subjects ingested $60 \mathrm{~g}$ skim milk powder (Campina, The Netherlands - Energy (En): 890 kJ, Protein: 22 g, Carbohydrate: 29 g; Fat: $0.4 \mathrm{~g}$ ) plus $1.5 \mathrm{~g}$ paracetamol (acetaminophen, Kruidvat, Leiden, The Netherlands) dissolved in water up to a volume of $500 \mathrm{~mL}$. Paracetamol was added to the beverage to assess gastric emptying rate. The protein bolus was ingested within a 5 min time period for both treatments. Following ingestion of the drink ( $t=0 \mathrm{~min}$ ), blood samples were collected at $t=15,30,45,60,90,120,180,240 \mathrm{~min}$. After the last blood sample was collected, subjects were slowly returned to an upright body position and re-acclimatized throughout a 10 min time period. 


\section{Gastric Emptying}

Gastric emptying rate was assessed by measuring the post-prandial rise in plasma paracetamol (acetaminophen) concentrations after ingestion of protein with $1.5 \mathrm{~g}$ paracetamol added $(21,52)$. With paracetamol being rapidly absorbed in the small intestine, gastric emptying forms the rate-limiting step determining the appearance rate of paracetamol in the circulation. Peak plasma paracetamol concentrations are typically reached after 30-60 min following ingestion with a $t^{1} / 2$ of $\sim 2 \mathrm{~h}$ (48). We used plasma paracetamol appearance in the circulation as a marker of gastric emptying rate as applied previously in our laboratory $(48)$ as well as others $(24,27,36)$.

\section{Plasma analysis}

Blood samples were collected in tubes containing EDTA and centrifuged at $1000 \mathrm{~g}$ for 10 min at $4{ }^{\circ} \mathrm{C}$. Aliquots of plasma were frozen in liquid nitrogen and stored at $-80^{\circ} \mathrm{C}$ until further analyses. Plasma glucose and insulin concentrations were analyzed using commercially available kits (Glucose HK CP, Horiba ABX Diagnostics, France, Ref: AA11A01667, and Human Insulin-specific (RIA), Merck Millipore, Germany, Cat \#: HI-14K, respectively). Plasma $(100 \mu \mathrm{L})$ for amino acid analyses was deproteinized on ice with 5sulphosalicylic acid, mixed and the clear supernatant was collected after centrifugation. Amino acid profiles were determined using ultra-performance liquid chromatography tandem mass spectrometry (UPLC-MS/MS) as described previously (51). Plasma paracetamol concentrations were analyzed with an acetaminophen assay kit (K991598, Roche, Basel, Switzerland) with the COBAS-Integra 800 immuno-assay analyzer. Briefly, acetaminophen is hydrolyzed to p-aminophenol and acetate. The p-aminophenol is then converted to an indophenol by enzymatic reaction. The production of indophenol is colorimetrically analyzed and is directly proportional to acetaminophen concentration in plasma.

\section{Statistics}

All data are displayed as means + SEM. Time-dependent variables such as plasma glucose, insulin, amino acid and paracetamol concentrations were analyzed using a two-way repeated measure ANOVA (time $\times$ treatment). Upon identification of a significant time $\times$ treatment interaction, Bonferroni post hoc testing was used to identify time points at which the treatments differed. Differences in treatment-dependent variables, such as area under the curve (AUC), were analyzed using a Student's paired $t$-test. Pearson's $r$ product moment correlation was used to examine the linear relationship between plasma essential amino acids and paracetamol AUC for each test. Statistical significance was set at $P<0.05$. All calculations were performed using SPSS 21.0 (SPSS Inc., Chicago, Illinois, USA). 


\section{Results}

Plasma glucose and insulin concentrations

Plasma glucose (Figure 5.1A) and insulin (Figure 5.1B) concentrations increased following protein ingestion in both treatments $(P<0.05)$. After reaching peak concentrations, plasma glucose concentrations decreased in both treatments and were significantly lower in the control vs inversion treatment between $t=60-240 \mathrm{~min}$ (time $\times$ treatment interaction, $P<$ 0.05). The increase in insulin was significantly different between the inversion and control treatments (time $\times$ treatment interaction, $P<0.05$ ). Peak post-prandial insulin concentrations were reached at $t=15 \mathrm{~min}$ and were significantly lower in the inversion vs control treatment (27 \pm 8 vs $\left.52 \pm 13 \mathrm{mU} \cdot \mathrm{L}^{-1}, P<0.05\right)$.

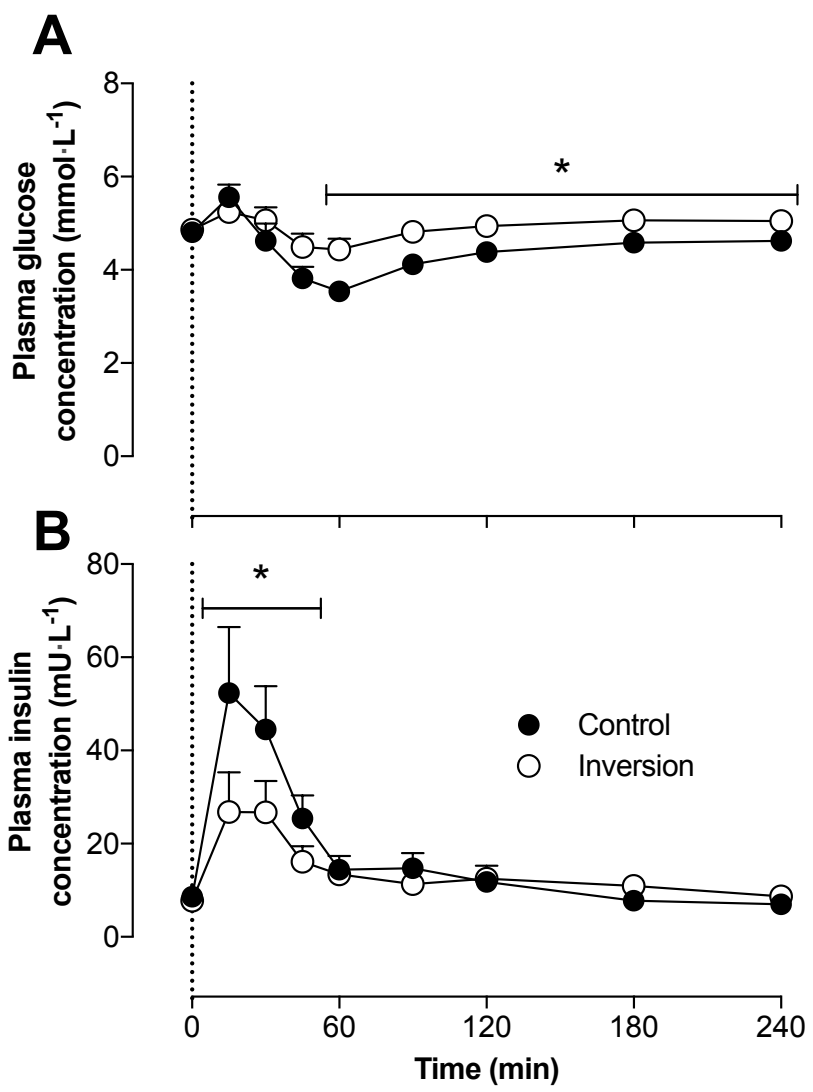

Figure 5.1 Mean (+SEM) plasma glucose $\left(\mathrm{mmol}^{\mathrm{L}} \mathrm{L}^{-1} ; \mathrm{A}\right)$ and insulin $\left(\mathrm{mU} \cdot \mathrm{L}^{-1} ; B\right)$ concentrations after protein ingestion while seated (Control; $n=8$ ) and in a $-20^{\circ}$ head-down tilted position (Inversion; $n=8$ ). The data were analyzed with a two-way repeated-measures (treatment $\times$ time) ANOVA. Glucose: time effect: $P<0.05$; time $\times$ treatment interaction: $P<0.05$. Insulin: time effect: $P<0.05$; time $\times$ treatment interaction: $P<0.05$. * Significant differences $(P<0.05)$ between treatments within each time point. 
Plasma amino acid responses

Plasma leucine (Figure 5.2A) and essential amino acid (Figure 5.2C) concentrations increased following protein ingestion in both treatments $(P<0.01)$. Plasma leucine and total essential amino acid concentrations showed an attenuated rise in the inversion compared with the control treatment, with concentrations being significantly lower in inversion treatment between $t=15-120 \mathrm{~min}(P<0.05)$. Overall leucine (Figure 5.2B) and essential amino acid availability (Figure 5.2D), expressed as AUC calculated over $240 \mathrm{~min}$, were lower in the inversion compared with control treatment $(P<0.05)$. No significant differences were observed in post-prandial non-essential amino acid availability (Figure 5.2F) between treatments (main effect for time, $P<0.05$; time $\times$ treatment interaction, $P>0.05$ ).

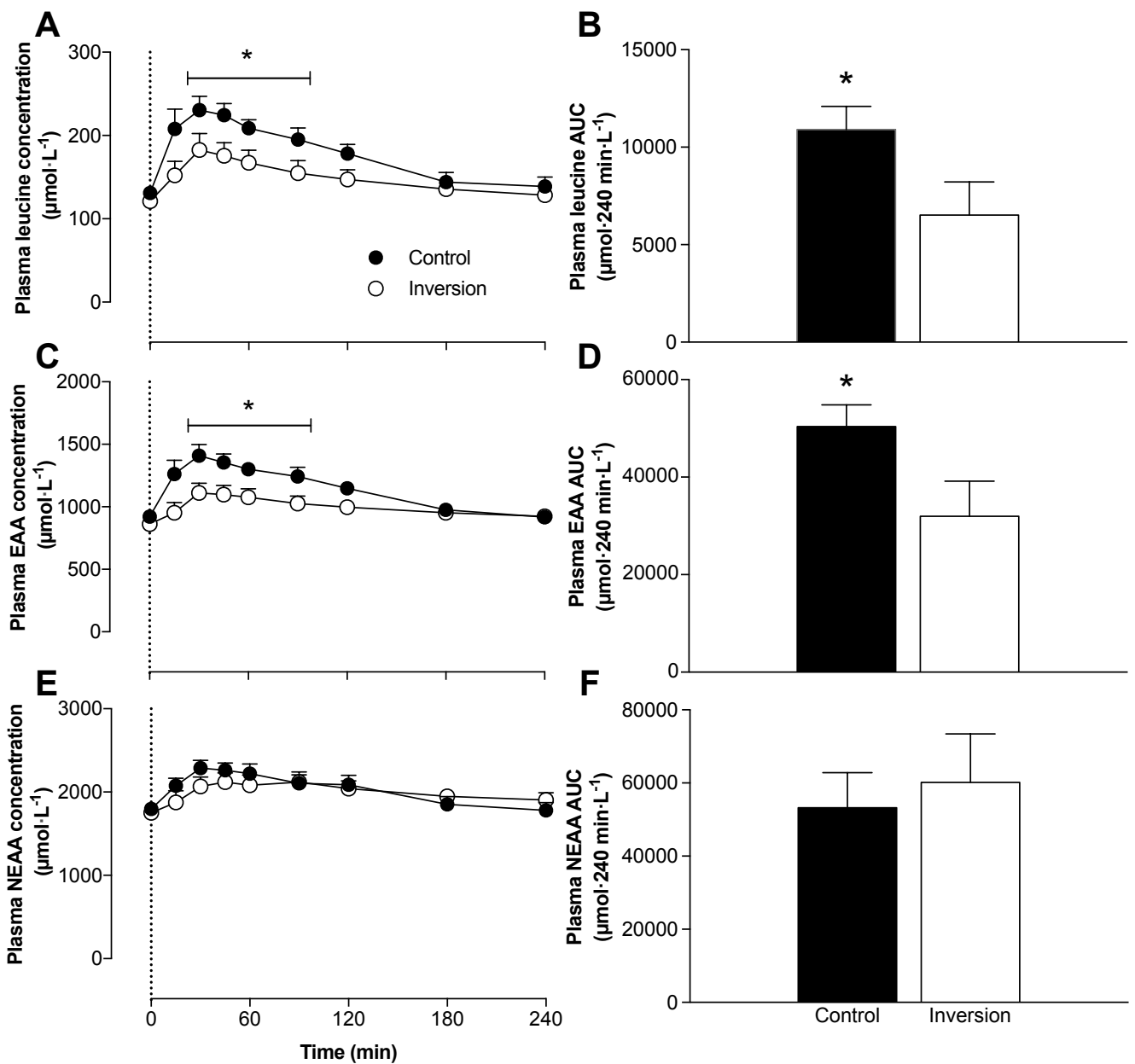

Figure 5.2 Mean (+SEM) plasma leucine (A), essential (EAAs; C) and non-essential (NEAAs; E) amino acid concentrations (umol/ $\mathrm{L}^{-1}$ ) after protein ingestion in a seated (Control; $n=8$ ) and in a $-20^{\circ}$ head-down tilted position (Inversion; $n=8$ ). The data were analyzed with a two-way repeated-measures (treatment $\times$ time) ANOVA. Leucine: time effect: $P<0.01$; time $\times$ treatment interaction: $P<0.05$. EAAs: time effect: $P<0.01$; time $x$ treatment interaction: $P<0.05$. NEAAs: time effect: $P<0.01$; time $\times$ treatment interaction: $P>0.05$. Area under the curve over 240 min for plasma leucine (B), EAA (D), and NEAA ( $F, \mu$ mol.240 min $\left.\cdot L^{-1}\right)$ were analyzed with a Student's paired t-test. *Significant differences $(P<0.05)$ between treatments within each time point. 


\section{Gastric Emptying}

Plasma paracetamol (Figure 5.3) concentrations increased following protein ingestion in both treatments $(P<0.05)$. An attenuated post-prandial rise in paracetamol concentrations was observed in the inversion compared with control treatment (time $\times$ treatment, $P<0.05$ ). Peak paracetamol concentrations reached $10.0 \pm 0.6 \mathrm{mg} \cdot \mathrm{L}^{-1}$ at $t=90 \mathrm{~min}$ in the control treatment and $5.8 \pm 1.1 \mathrm{mg} \cdot \mathrm{L}^{-1}$ at $t=120 \mathrm{~min}(P<0.05)$ in the inversion treatment. Gastric emptying rate during the early post-prandial phase, assessed by paracetamol AUC from $t=$ 0-60 min was $54 \pm 13 \%$ lower in the inversion compared with control treatment (132 \pm 37 vs $\left.344 \pm 47 \mathrm{mg} \cdot 240 \mathrm{~min} \cdot \mathrm{L}^{-1} ; P<0.05\right)$. When assessed over the entire $240 \mathrm{~min}$ post-prandial period, paracetamol AUC was $38 \pm 13 \%$ lower in the inversion compared with control treatment $1054 \pm 196$ vs $1693 \pm 101 \mathrm{AU} ; P<0.05)$.
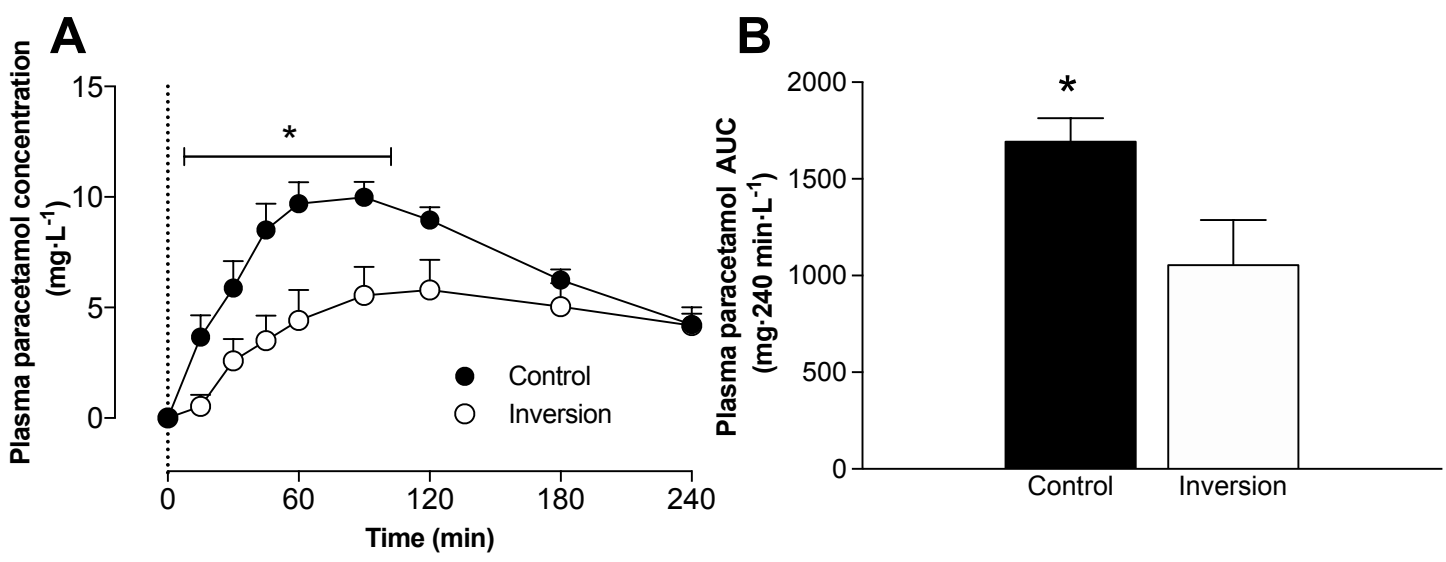

Figure 5.3 Mean (+SEM) plasma paracetamol concentrations $\left(m g \cdot \mathrm{L}^{-1}\right)$ after protein ingestion in a seated (Control; $n=7$ ) and a $-20^{\circ}$ head-down tilted position (Inversion; $n=7$ ). The data were analyzed with a two-way repeated-measures (treatment $\times$ time) ANOVA. Time effect: $P<0.05$; time $\times$ treatment interaction: $P<0.05$. Area under the curve over $240 \mathrm{~min}\left(B, \mathrm{mg} \cdot 240 \mathrm{~min} \cdot \mathrm{L}^{-1}\right)$ were analyzed with a Student's paired t-test. *Significant differences $(P<0.05)$ between treatments within each time point.

Pearson's $r$ product moment correlation was performed between plasma essential amino acids and paracetamol AUCs over the 240 min post-prandial period (Figure 5.4). A significant positive $(r=0.68 ; P<0.01)$ correlation was detected between plasma essential amino acids and paracetamol AUCs. 
Chapter 5

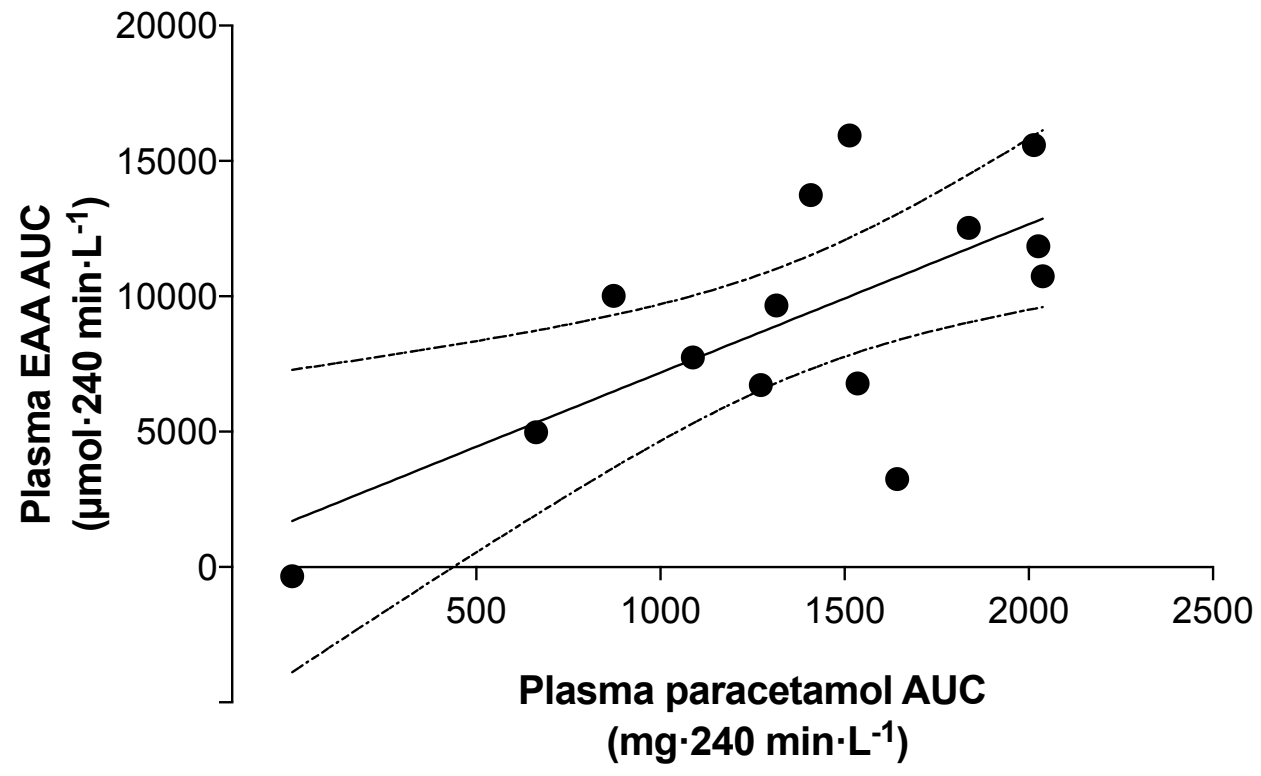

Figure 5.4 Correlation between post-prandial plasma essential amino acid (EAA) and paracetamol availability. Values represent area under the curve (AUC, $\mathrm{mg} \cdot 240 \mathrm{~min} \cdot \mathrm{L}^{-1}$ ) calculations based on plasma essential amino acid and paracetamol concentrations measured over $240 \mathrm{~min}$ in each trial $(n=14$, one subject on both trials did not ingest paracetamol). The solid line indicates the linear regression line of best fit and the dashed lines represent the $95 \%$ confidence interval. A significant positive correlation was observed $(r=0.68 ; P<0.01)$. 


\section{Discussion}

In the present study, we observed that gastric emptying rates were reduced when protein was ingested in an inverted versus upright seated position. The post-prandial rise in circulating amino acid concentrations was attenuated following protein ingestion in the head-down tilted position along with substantially lower post-prandial amino acid availability when compared to feeding in the upright seated position.

It has been well established that the post-prandial rise in plasma essential amino acid concentrations following food ingestion increases muscle protein synthesis rates $(13,15,18$, 50). In the present study, we observed a rapid rise in plasma glucose and insulin (Figure 5.1) and essential amino acid (Figure 5.2C) concentrations following ingestion of a single, meallike amount of protein when sitting in a normal, upright position. Total essential amino acid concentrations increased rapidly, reaching peak levels of $1408 \pm 80 \mu \mathrm{mol} \cdot \mathrm{L}^{-1}$ within $30 \mathrm{~min}$ after ingesting $22 \mathrm{~g}$ of milk protein. In line, plasma leucine concentrations rapidly reached peak levels of $236 \pm 15 \mu \mathrm{mol} \cdot \mathrm{L}^{-1}$ within the same post-prandial time frame (Figure 5.2A). The level of increase in plasma essential amino acid concentrations, and leucine in particular, observed in the control treatment have been previously shown to result in post-prandial muscle protein synthesis rates that were 30-100\% higher when compared to basal, postabsorptive muscle protein synthesis rates $(5,8,23,30,53,54)$.

When the same bolus of protein was ingested in an inverted body position, the post-prandial rises in plasma insulin (Figure 5.1B), essential amino acid (Figure 5.2C), and leucine (Figure 5.2A) concentrations were substantially reduced. Peak plasma essential amino acids, and leucine in particular, reached levels of $1112 \pm 70$ and $177 \pm 15 \mu \mathrm{mol} \cdot \mathrm{L}^{-1}$, respectively, which were substantially lower when compared to concentrations observed after ingesting protein in an upright seated position $(P<0.05)$. The extent of the difference in the post-prandial rise in amino acid concentrations following ingestion of a meal-like amount of protein in an inverted versus a normal, upright seated position was beyond our expectations. The blunted post-prandial rise in plasma essential amino acid concentrations, and leucine concentrations in particular, observed in the inversion treatment would unlikely suffice to induce a measurable increase in post-prandial muscle protein synthesis rates as shown in previous work $(42,53)$.

Besides the blunted post-prandial rise in amino acid concentrations following feeding in the inverted versus upright seated position, we also observed lower plasma essential amino acid (Figure 5.2D) and leucine (Figure 5.2B) availability over the $4 \mathrm{~h}$ post-prandial period (Figure 5.2). These findings are in line with Koopman et al. who showed that ingestion of a single 35 $\mathrm{g}$ bolus of intact, micellar casein resulted in less protein-derived amino acids being released into the circulation when compared with the ingestion of the same amount of hydrolyzed casein (29). The reduction in protein-derived amino acid release could be attributed to reduced gastric emptying rates and/or greater splanchnic amino acid retention following ingestion of a more slowly digested protein. In the present study, we assessed gastric 
emptying rates by measuring the increase in plasma paracetamol concentrations following the co-ingestion of $1.5 \mathrm{~g}$ paracetamol $(21,25,48,52)$. Peak plasma paracetamol concentration was substantially lower (5.8 vs $10.0 \mathrm{mg} \cdot \mathrm{L}^{-1}$ ) and was reached $30 \mathrm{~min}$ later when protein was ingested in the inverted compared with the upright seated position (Figure 5.3). The attenuated rise in plasma paracetamol concentrations following protein ingestion implies that gastric emptying rates were substantially reduced in the inverted versus upright seated position. Furthermore, we found that the overall appearance of plasma paracetamol was positively correlated with the overall plasma essential amino acid availability (Figure 5.4). The reduction in gastric emptying rate demonstrated in the inverted position may be partly explained by recently published work using computer modelling techniques to demonstrate that the movement of stomach content is slowed in a supine position due to a lower amount of stomach content gathering near the pylorus (28). Therefore, we conclude that the attenuated post-prandial rise in plasma amino acid concentrations following ingestion of protein in an inverted compared with an upright seated position can, at least partly, be attributed to a reduction in gastric emptying rates.

The present findings may be of relevance in various settings of disuse atrophy. Disuse atrophy has been partly attributed to a reduced sensitivity of the muscle protein synthetic response to the post-prandial rise in plasma amino acid concentrations, and leucine concentrations in particular $(22,49)$. Feeding hospitalized patients in a supine as opposed to a normal upright sitting position may attenuate the post-prandial rise in plasma amino acid concentrations, contributing to anabolic resistance in these patients. Proper upright body positioning may be an important pre-requisite to increase the post-prandial rise in plasma amino acid availability, thereby increasing the post-prandial muscle protein synthetic response to meal ingestion. In other words, our mothers may have been right in more than one way by telling us to sit up straight at the dinner table. Lastly, the present findings imply that part of the muscle lost by astronauts due to microgravity $(1,47)$ may also be explained by reduced protein digestion and amino acid absorption, thereby attenuating the postprandial rise in plasma amino acid concentrations and lowering the post-prandial muscle protein synthetic response to food intake.

Changes in body position substantially modulate gastric emptying rate and the subsequent post-prandial rise in plasma amino acid availability. Therefore, an upright body position during and after feeding is important for adequate nutrient absorption and should be considered when aiming to optimize post-prandial muscle protein accretion in both health and disease. 
Inverted body position impacts post-prandial amino acid availability

\section{References}

1. Akima H, Kawakami $\mathbf{Y}$, Kubo K, Sekiguchi C, Ohshima H, Miyamoto A, Fukunaga T. Effect of shortduration spaceflight on thigh and leg muscle volume. Med Sci Sports Exerc 32: 1743-1747, 2000.

2. Bax M-L, Aubry L, Ferreira C, Daudin J-D, Gatellier P, Rémond D, Santé-Lhoutellier V. Cooking temperature is a key determinant of in vitro meat protein digestion rate: investigation of underlying mechanisms. J Agric Food Chem 60: 2569-2576, 2012.

3. Boirie $\mathbf{Y}$, Dangin M, Gachon P, Vasson MP, Maubois JL, Beaufrere B. Slow and fast dietary proteins differently modulate postprandial protein accretion. Proc Natl Acad Sci USA 94: 14930-14935, 1997.

4. Boirie Y, Gachon P, Corny S, Fauquant J, Maubois JL, Beaufrere B. Acute postprandial changes in leucine metabolism as assessed with an intrinsically labeled milk protein. Am J Physiol 271: E1083-91, 1996.

5. Burd NA, Gorissen SH, van Vliet S, Snijders T, van Loon LJ. Differences in postprandial protein handling after beef compared with milk ingestion during postexercise recovery: a randomized controlled trial. Am J Clin Nutr 102: 828-836, 2015.

6. Calbet JAL, Holst JJ. Gastric emptying, gastric secretion and enterogastrone response after administration of milk proteins or their peptide hydrolysates in humans. Eur J Nutr 43: 127-139, 2004.

7. Churchward-Venne TA, Burd NA, Mitchell CJ, West DWD, Philp A, Marcotte GR, Baker SK, Baar K, Phillips SM. Supplementation of a suboptimal protein dose with leucine or essential amino acids: effects on myofibrillar protein synthesis at rest and following resistance exercise in men. J Physiol 590: 27512765, 2012

8. Churchward-Venne TA, Snijders T, Linkens AMA, Hamer HM, van Kranenburg J, van Loon LJC Ingestion of Casein in a Milk Matrix Modulates Dietary Protein Digestion and Absorption Kinetics but Does Not Modulate Postprandial Muscle Protein Synthesis in Older Men. J Nutr 145: 1438-1445, 2015.

9. Cuthbertson D, Smith K, Babraj J, Leese G, Waddell T, Atherton P, Wackerhage H, Taylor PM, Rennie MJ. Anabolic signaling deficits underlie amino acid resistance of wasting, aging muscle. FASEB J 19: 422424, 2005

10. Dangin $\mathbf{M}$, Boirie $\mathbf{Y}$, Garcia-Rodenas $\mathbf{C}$, Gachon $\mathbf{P}$, Fauquant $\mathrm{J}$, Callier $\mathbf{P}$, Ballèvre $\mathbf{O}$, Beaufrere $\mathbf{B}$. The digestion rate of protein is an independent regulating factor of postprandial protein retention. Am $J$ Physiol Endocrinol Metab 280: E340-8, 2001.

11. Dangin $\mathbf{M}$, Boirie $\mathbf{Y}$, Guillet $\mathbf{C}$, Beaufrère $\mathbf{B}$. Influence of the protein digestion rate on protein turnover in young and elderly subjects. J Nutr 132: 3228S-33S, 2002.

12. Dickinson JM, Drummond MJ, Coben JR, Volpi E, Rasmussen BB. Aging differentially affects human skeletal muscle amino acid transporter expression when essential amino acids are ingested after exercise. Clin Nutr 32: 273-280, 2013.

13. Dickinson JM, Gundermann DM, Walker DK, Reidy PT, Borack MS, Drummond MJ, Arora M, Volpi E Rasmussen BB. Leucine-enriched amino acid ingestion after resistance exercise prolongs myofibrillar protein synthesis and amino acid transporter expression in older men. J Nutr 144: 1694-1702, 2014.

14. Dideriksen KJ, Reitelseder S, Petersen SG, Hjort M, Helmark IC, Kjaer M, Holm L. Stimulation of muscle protein synthesis by whey and caseinate ingestion after resistance exercise in elderly individuals. Scand J Med Sci Sports 21: e372-83, 2011.

15. Dreyer HC, Drummond MJ, Pennings B, Fujita S, Glynn EL, Chinkes DL, Dhanani S, Volpi E, Rasmussen BB. Leucine-enriched essential amino acid and carbohydrate ingestion following resistance exercise enhances mTOR signaling and protein synthesis in human muscle. Am J Physiol Endocrinol Metab 294: E392-400, 2008.

16. Dreyer HC, Volpi E. Role of protein and amino acids in the pathophysiology and treatment of sarcopenia. J Am Coll Nutr 24: 140S-145S, 2005.

17. Drummond MJ, Dickinson JM, Fry CS, Walker DK, Gundermann DM, Reidy PT, Timmerman KL, Markofski MM, Paddon-Jones D, Rasmussen BB, Volpi E. Bed rest impairs skeletal muscle amino acid transporter expression, mTORC1 signaling, and protein synthesis in response to essential amino acids in older adults. Am J Physiol Endocrinol Metab 302: E1113-22, 2012.

18. Drummond MJ, Rasmussen BB. Leucine-enriched nutrients and the regulation of mammalian target of rapamycin signalling and human skeletal muscle protein synthesis. Curr Opin Clin Nutr Metab Care 11: 222-226, 2008.

19. Evenepoel P, Geypens B, Luypaerts A, Hiele M, Ghoos Y, Rutgeerts P. Digestibility of cooked and raw egg protein in humans as assessed by stable isotope techniques. J Nutr 128: 1716-1722, 1998. 
20. Fry CS, Drummond MJ, Glynn EL, Dickinson JM, Gundermann DM, Timmerman KL, Walker DK, Dhanani S, Volpi E, Rasmussen BB. Aging impairs contraction-induced human skeletal muscle mTORC1 signaling and protein synthesis. Skelet Muscle 1: 11, 2011.

21. Glerup H, Bluhme H, Villadsen GE, Rasmussen K, Ejskjaer N, Dahlerup JF. Gastric emptying: a comparison of three methods. Scand J Gastroenterol 42: 1182-1186, 2007.

22. Glover El, Phillips SM, Oates BR, Tang JE, Tarnopolsky MA, Selby A, Smith K, Rennie MJ. Immobilization induces anabolic resistance in human myofibrillar protein synthesis with low and high dose amino acid infusion. J Physiol 586: 6049-6061, 2008.

23. Gorissen SHM, Burd NA, Hamer HM, Gijsen AP, Groen BB, van Loon LJC. Carbohydrate coingestion delays dietary protein digestion and absorption but does not modulate postprandial muscle protein accretion. J Clin Endocrinol Metab 99: 2250-2258, 2014.

24. Harmuth S, Wewalka M, Holst JJ, Nemecek R, Thalhammer S, Schmid R, Sahora K, Gnant M, Miholić $\mathbf{J}$. Distal gastrectomy in pancreaticoduodenectomy is associated with accelerated gastric emptying, enhanced postprandial release of GLP-1, and improved insulin sensitivity. J Gastrointest Surg 18: 52-59, 2014.

25. Heading RC, Nimmo J, Prescott LF, Tothill P. The dependence of paracetamol absorption on the rate of gastric emptying. Br J Pharmacol 47: 415-421, 1973.

26. Hector AJ, Marcotte GR, Churchward-Venne TA, Murphy CH, Breen L, Allmen Von M, Baker SK, Phillips SM. Whey protein supplementation preserves postprandial myofibrillar protein synthesis during short-term energy restriction in overweight and obese adults. J Nutr 145: 246-252, 2015.

27. Horowitz M, Flint A, Jones KL, Hindsberger C, Rasmussen MF, Kapitza C, Doran S, Jax T, Zdravkovic M, Chapman IM. Effect of the once-daily human GLP-1 analogue liraglutide on appetite, energy intake, energy expenditure and gastric emptying in type 2 diabetes. Diabetes Res Clin Pract 97: 258-266, 2012.

28. Imai Y, Kobayashi I, Ishida S, Ishikawa T, Buist M, Yamaguchi T. Antral recirculation in the stomach during gastric mixing. AJP: Gastrointestinal and Liver Physiology 304: G536-G542, 2013.

29. Koopman R, Crombach N, Gijsen AP, Walrand S, Fauquant J, Kies AK, Lemosquet S, Saris WHM Boirie Y, van Loon LJC. Ingestion of a protein hydrolysate is accompanied by an accelerated in vivo digestion and absorption rate when compared with its intact protein. Am J Clin Nutr 90: 106-115, 2009.

30. Kouw IWK, Gorissen SHM, Burd NA, Cermak NM, Gijsen AP, van Kranenburg J, van Loon LJC Postprandial Protein Handling Is Not Impaired in Type 2 Diabetes Patients When Compared With Normoglycemic Controls. J Clin Endocrinol Metab 100: 3103-3111, 2015.

31. Kumar V, Selby A, Rankin D, Patel R, Atherton P, Hildebrandt W, Williams J, Smith K, Seynnes O, Hiscock N, Rennie MJ. Age-related differences in the dose-response relationship of muscle protein synthesis to resistance exercise in young and old men. J Physiol 587: 211-217, 2009.

32. Mahé S, Roos N, Benamouzig R, Davin L, Luengo C, Gagnon L, Gaussergès N, Rautureau J, Tomé D. Gastrojejunal kinetics and the digestion of [15N]beta-lactoglobulin and casein in humans: the influence of the nature and quantity of the protein. Am J Clin Nutr 63: 546-552, 1996.

33. Mamerow MM, Mettler JA, English KL, Casperson SL, Arentson-Lantz E, Sheffield-Moore M, Layman DK, Paddon-Jones D. Dietary protein distribution positively influences $24-h$ muscle protein synthesis in healthy adults. J Nutr 144: 876-880, 2014.

34. Murphy $\mathrm{CH}$, Churchward-Venne TA, Mitchell CJ, Kolar NM, Kassis A, Karagounis LG, Burke LM, Hawley JA, Phillips SM. Hypoenergetic diet-induced reductions in myofibrillar protein synthesis are restored with resistance training and balanced daily protein ingestion in older men. Am J Physiol Endocrinol Metab 308: E734-43, 2015.

35. Paddon-Jones D, Sheffield-Moore M, Katsanos CS, Zhang X-J, Wolfe RR. Differential stimulation of muscle protein synthesis in elderly humans following isocaloric ingestion of amino acids or whey protein. Exp Gerontol 41: 215-219, 2006.

36. Panahi S, Khoury EI D, Kubant R, Akhavan T, Luhovyy BL, Goff HD, Anderson GH. Mechanism of action of whole milk and its components on glycemic control in healthy young men. J Nutr Biochem 25: 1124 1131, 2014.

37. Pennings B, Boirie Y, Senden JMG, Gijsen AP, Kuipers H, van Loon LJC. Whey protein stimulates postprandial muscle protein accretion more effectively than do casein and casein hydrolysate in older men. Am J Clin Nutr 93: 997-1005, 2011.

38. Pennings B, Groen B, de Lange A, Gijsen AP, Zorenc AH, Senden JMG, van Loon LJC. Amino acid absorption and subsequent muscle protein accretion following graded intakes of whey protein in elderly men. Am J Physiol Endocrinol Metab 302: E992-9, 2012. 
39. Pennings B, Groen BBL, van Dijk J-W, de Lange A, Kiskini A, Kuklinski M, Senden JMG, van Loon LJC. Minced beef is more rapidly digested and absorbed than beef steak, resulting in greater postprandial protein retention in older men. Am J Clin Nutr 98: 121-128, 2013.

40. Rasmussen BB, Fujita S, Wolfe RR, Mittendorfer B, Roy M, Rowe VL, Volpi E. Insulin resistance of muscle protein metabolism in aging. FASEB J 20: 768-769, 2006.

41. Reitelseder S, Agergaard J, Doessing S, Helmark IC, Lund P, Kristensen NB, Frystyk J, Flyvbjerg A Schjerling P, van Hall G, Kjaer M, Holm L. Whey and casein labeled with L-[1-13C]leucine and muscle protein synthesis: effect of resistance exercise and protein ingestion. Am J Physiol Endocrinol Metab 300: E231-42, 2011.

42. Robinson MJ, Burd NA, Breen L, Rerecich T, Yang Y, Hector AJ, Baker SK, Phillips SM. Dosedependent responses of myofibrillar protein synthesis with beef ingestion are enhanced with resistance exercise in middle-aged men. Appl Physiol Nutr Metab 38: 120-125, 2013.

43. Soop M, Nehra V, Henderson GC, Boirie Y, Ford GC, Nair KS. Coingestion of whey protein and casein in a mixed meal: demonstration of a more sustained anabolic effect of casein. Am J Physiol Endocrinol Metab 303: E152-62, 2012.

44. Staples AW, Burd NA, West DWD, Currie KD, Atherton PJ, Moore DR, Rennie MJ, MacDonald MJ Baker SK, Phillips SM. Carbohydrate does not augment exercise-induced protein accretion versus protein alone. Med Sci Sports Exerc 43: 1154-1161, 2011.

45. Symons TB, Sheffield-Moore M, Wolfe RR, Paddon-Jones D. A moderate serving of high-quality protein maximally stimulates skeletal muscle protein synthesis in young and elderly subjects. J Am Diet Assoc 109: 1582-1586, 2009.

46. Tang JE, Moore DR, Kujbida GW, Tarnopolsky MA, Phillips SM. Ingestion of whey hydrolysate, casein, or soy protein isolate: effects on mixed muscle protein synthesis at rest and following resistance exercise in young men. J Appl Physiol 107: 987-992, 2009.

47. Trappe S, Costill D, Gallagher P, Creer A, Peters JR, Evans H, Riley DA, Fitts RH. Exercise in space: human skeletal muscle after 6 months aboard the International Space Station. J Appl Physiol 106: 11591168, 2009.

48. van Can J, Sloth B, Jensen CB, Flint A, Blaak EE, Saris WHM. Effects of the once-daily GLP-1 analog liraglutide on gastric emptying, glycemic parameters, appetite and energy metabolism in obese, nondiabetic adults. Int J Obes 38: 784-793, 2014.

49. Wall BT, Dirks ML, Snijders T, van Dijk J-W, Fritsch M, Verdijk LB, van Loon LJC. Short-term muscle disuse lowers myofibrillar protein synthesis rates and induces anabolic resistance to protein ingestion. Am J Physiol Endocrinol Metab 310: E137-47, 2016.

50. Wall BT, Hamer HM, de Lange A, Kiskini A, Groen BBL, Senden JMG, Gijsen AP, Verdijk LB, van Loon LJC. Leucine co-ingestion improves post-prandial muscle protein accretion in elderly men. Clin Nutr 32: 412-419, 2013.

51. Waterval WAH, Scheijen JLJM, Ortmans-Ploemen MMJC, Habets-van der Poel CD, Bierau J. Quantitative UPLC-MS/MS analysis of underivatised amino acids in body fluids is a reliable tool for the diagnosis and follow-up of patients with inborn errors of metabolism. Clin Chim Acta 407: 36-42, 2009.

52. Willems M, Quartero AO, Numans ME. How useful is paracetamol absorption as a marker of gastric emptying? A systematic literature study. Dig Dis Sci 46: 2256-2262, 2001.

53. Yang Y, Breen L, Burd NA, Hector AJ, Churchward-Venne TA, Josse AR, Tarnopolsky MA, Phillips SM Resistance exercise enhances myofibrillar protein synthesis with graded intakes of whey protein in older men. Br J Nutr 108: 1780-1788, 2012.

54. Yang Y, Churchward-Venne TA, Burd NA, Breen L, Tarnopolsky MA, Phillips SM. Myofibrillar protein synthesis following ingestion of soy protein isolate at rest and after resistance exercise in elderly men. Nutr Metab 9: 57, 2012. 



\section{Chapter 6}

Food ingestion in an upright sitting position increases postprandial amino acid availability when compared to food ingestion in a lying down position

Andrew M. Holwerda, Kaatje Lenaerts, Jörgen Bierau, Will K.W.H. Wodzig and Luc J.C. van Loon

Applied Physiology, Nutrition, and Metabolism, 42(7), 738-743. 2017. 
Chapter 6

\section{Abstract}

Background Dietary protein digestion and absorption kinetics determine the post-prandial increase in muscle protein synthesis. We recently demonstrated that body position during feeding can modulate the post-prandial rise in plasma amino acid availability.

Objective We investigated whether protein ingestion in an upright sitting body position accelerates gastric emptying and improves dietary protein digestion and subsequent amino acid absorption compared with feeding in a supine lying body position.

Methods In a crossover design, eight young males $\left(26 \pm 1 \mathrm{y}, 24.0 \pm 0.9 \mathrm{~kg}^{-2}\right)$ ingested $20 \mathrm{~g}$ intrinsically $\mathrm{L}-\left[1-{ }^{13} \mathrm{C}\right]$-phenylalanine labeled milk protein plus $1.5 \mathrm{~g}$ paracetamol while sitting in an upright position or lying down in a supine position. Blood samples were collected frequently during a $5 \mathrm{~h}$ post-prandial period. Gastric emptying rates and dietary protein digestion and absorption were assessed using plasma paracetamol and amino acid concentrations as well as plasma L- $\left[1-{ }^{13} \mathrm{C}\right]$-phenylalanine enrichments.

Results Peak plasma leucine concentrations were higher when protein was ingested in an upright sitting vs lying position (213 \pm 15 vs $\left.193 \pm 12 \mu \mathrm{mol} \cdot \mathrm{L}^{-1}, P<0.05\right)$, which was accompanied by a trend for a greater overall leucine response (13989 \pm 720 vs $11875 \pm 1073 \mu \mathrm{mol} \cdot 300 \mathrm{~min} \cdot \mathrm{L}^{-1}$, respectively; $\left.P=0.05\right)$. Peak plasma paracetamol concentrations were higher in the sitting vs lying treatment $\left(11.6 \pm 0.5\right.$ vs $\left.9.3 \pm 0.6 \mathrm{mg} \cdot \mathrm{L}^{-1}, P<0.05\right)$.

Conclusions Protein ingestion in an upright sitting position accelerates gastric emptying and increases the post-prandial rise in plasma amino acid availability by increasing protein digestion and amino acid absorption rates. Therefore, feeding in an upright body position as opposed to a lying position is an important prerequisite to allow proper post-prandial muscle protein accretion. 


\section{Introduction}

Protein ingestion increases muscle protein synthesis rates $(2,28,29)$. The post-prandial increase in muscle protein synthesis rate has been attributed to the rise in circulating (essential) amino acid concentrations, with the post-prandial rise in circulating plasma leucine concentrations being of particular relevance $(8,26)$. Regulation of the post-prandial muscle protein synthetic response occurs on multiple levels, ranging from protein digestion and amino acid absorption (16), post-prandial insulin release and subsequent muscle perfusion (21), amino acid uptake in muscle (7), activation of anabolic signaling pathways (10), and subsequent myofibrillar protein synthesis $(2,28,29)$. Differences in the anabolic properties of various proteins have been attributed to their amino acid composition (4) as well as their specific protein digestion and amino acid absorption kinetics (3).

The post-prandial muscle protein synthetic response to feeding is influenced by various factors that may modulate post-prandial protein digestion and amino acid absorption $(6,16$, 18). For example, the post-prandial stimulation of muscle protein synthesis can be influenced by the type of protein $(6,18)$, the matrix in which the protein is consumed $(5,22)$, the macronutrient composition of a protein rich meal (13) as well as actual food preparation procedures $(1,20)$ and mastication (9). We recently identified body position during and/or after feeding as an important factor influencing the post-prandial muscle protein synthetic response. We demonstrated that ingesting $22 \mathrm{~g}$ protein in a head-down tilted body position slows down gastric emptying rate and substantially lowers post-prandial plasma amino acid availability when compared to the ingestion of the same amount of protein in a proper upright sitting body position (14).

Based upon these proof-of-principle findings, we hypothesized that food intake in an upright sitting position results in more rapid gastric emptying, thereby accelerating protein digestion and subsequent amino acid absorption when compared to feeding in a lying position. Understanding the impact of body position on protein digestion and absorption is of important clinical relevance as many patients in the hospital remain in a lying position during and/or after feeding. Based upon our hypothesis, feeding in a lying body position could impair post-prandial protein handling and, as such, contribute to the development of anabolic resistance during bed rest following injury or disease.

To test our hypothesis that post-prandial protein handling differs when protein is ingested in an upright sitting versus lying down position, we selected a group of males who were subjected to two experiments where gastric emptying rate and protein digestion were assessed after consuming $20 \mathrm{~g}$ protein in an upright sitting versus lying down position. To simultaneously assess gastric emptying rates and protein digestion and amino acid absorption, subjects were administered $20 \mathrm{~g}$ intrinsically L- $\left[1-{ }^{13} \mathrm{C}\right]$-phenylalanine-labeled milk protein (24) mixed with $1.5 \mathrm{~g}$ paracetamol (acetaminophen) $(14,17,23)$. This study extends upon our previous work (14) and shows that protein ingestion in an upright, sitting body 
Chapter 6

position accelerates gastric emptying rate when compared to protein ingestion in a lying down body position, resulting in more rapid protein digestion and amino acid absorption. 


\title{
Materials and methods
}

\author{
Subjects
}

Eight healthy young subjects $\left(26 \pm 1 \mathrm{y}, 24.0 \pm 0.9 \mathrm{~kg} \cdot \mathrm{m}^{-2}\right)$ participated in this randomized, cross-over trial. Subjects were included if they were between the ages of 18 and $35 \mathrm{y}$ with a BMI between 18 and $30 \mathrm{~kg} \cdot \mathrm{m}^{-2}$. Potential subjects were excluded if they reported gastrointestinal dysfunction/disease (lactose intolerance, celiac disease) or if they were taking any form of medication that could impair gastrointestinal function. All participants were informed about the purpose of the study, experimental procedures, and possible risks prior to providing written consent to participate. This study was approved by the Medical Ethical Committee of the Maastricht University Medical Centre, The Netherlands and conformed to standards for the use of human subjects in research as outlined in the seventh revision of the Declaration of Helsinki (Brazil, 2013). This study was registered at the Netherlands Trial Register (http://www.trialregister.nl) as NTR5027.

\section{Diet and physical activity before testing}

All subjects were instructed to keep their diet consistent, to refrain from alcohol consumption and to refrain from performing any exhaustive physical activity for two days before each test day. Subjects reported to the lab for each test day under resting and fasted conditions, having not eaten anything from $2200 \mathrm{~h}$ the night before testing.

\section{Experimental Procedure}

According to the randomized, cross-over study design, each subject ingested $20 \mathrm{~g} \mathrm{~L}-\left[1-{ }^{13} \mathrm{C}\right]-$ phenylalanine-labeled milk protein (MPC80) mixed with $1.5 \mathrm{~g}$ paracetamol powder (acetaminophen, Kruidvat, Leiden, The Netherlands) once while sitting in an upright body position and once while lying in a supine horizontal body position. Subjects remained in the respective body position for the duration of each trial (330 min total). Each trial was separated by a minimum of 6 days. Subjects ingested the test drink through a spout of a sports drink bottle to prevent any spillage. Drink ingestion time in both treatment positions was standardized to $5 \mathrm{~min}$. The provision of paracetamol in combination with repeated blood sampling over a $5 \mathrm{~h}$ post-prandial period allowed for assessment of gastric emptying rate (see below for methodological description). The provision of intrinsically L- $\left[1-{ }^{13} \mathrm{C}\right]-$ phenylalanine labeled protein combined with repeated blood sampling over a $5 \mathrm{~h}$ postprandial period allows assessment of dietary protein digestion and amino acid absorption. Upon ingestion and subsequent digestion of the intrinsically L-[ $\left[1-{ }^{13} \mathrm{C}\right]$-phenylalanine labeled protein, increases in $\mathrm{L}-\left[1-{ }^{13} \mathrm{C}\right]$-phenylalanine enrichment in the circulation provide a reference 
measurement for protein digestion and subsequent absorption of dietary protein-derived amino acids.

\section{Testing Protocol}

After an overnight fast, a polyurethane catheter was placed in the antecubetal vein of the elbow for frequent blood sampling. At $t=-30 \mathrm{~min}$, a basal blood sample was collected from the catheter and blood pressure and heart rate was measured once at the upper arm and once at the ankle. After baseline measurements, subjects positioned themselves in either the sitting or supine position based on randomization. While in the seated position, subjects sat in a standardized, stationary chair with arm rests and were instructed to hold their lower back against the back support of the chair. Subjects were supervised throughout the test day and were constantly reminded to maintain the upright posture. For the lying treatment, subjects were laid in a standard hospital bed and were instructed to lay supine for the duration of the trial. Subjects were given a pillow to rest their heads, which was positioned so that the upper back would remain in contact with the bed. After subjects were positioned in the respective body positions of each treatment, they acclimatized for $30 \mathrm{~min}$, after which another blood sample was collected and blood pressure and heart rate were measured $(t=$ $0 \mathrm{~min})$. Following these measurements, the test drink was ingested, signifying the start of the $300 \mathrm{~min}$ post-prandial period. Venous blood samples were collected at $t=15,30,45$, $60,90,120,180,240$ and $300 \mathrm{~min}$. Blood samples were collected in EDTA containing tubes and centrifuged at $1000 \mathrm{~g}$ for $10 \mathrm{~min}$ at $4{ }^{\circ} \mathrm{C}$. Aliquots of plasma were frozen in liquid nitrogen and stored at $-80^{\circ} \mathrm{C}$. Blood pressure and heart rate was measured at the upper arm and ankle at $t=60,120,180,240,300 \mathrm{~min}$.

\section{Preparation of study beverage}

Subjects ingested $20 \mathrm{~g}$ intrinsically L- $\left[1-{ }^{13} \mathrm{C}\right]$-phenylalanine labeled milk protein (MPC80) with an added $1.5 \mathrm{~g}$ paracetamol powder dissolved in water up to $500 \mathrm{~mL}$. We chose to use intrinsically labeled milk as opposed to either rapid or more slowly digestible whey or micellar casein fractions $(6,16)$, as milk and milk protein based products are generally part of our diets. The intrinsically L- $\left[1-{ }^{13} \mathrm{C}\right]$-phenylalanine-labeled milk protein was obtained by infusing a Holstein cow with large quantities of $\mathrm{L}-\left[1-{ }^{13} \mathrm{C}\right]$-phenylalanine, collecting the milk and purifying the milk protein fraction as described previously (24). The L-[1-13C]phenylalanine enrichment of the intact MPC80 was 7.7 mole percent excess (MPE). The MPC80 met all chemical and bacteriologic specifications for human consumption.

\section{Gastric Emptying}


Gastric emptying was assessed by measuring the post-prandial rise in plasma paracetamol (acetaminophen) concentrations after ingestion of protein with $1.5 \mathrm{~g}$ paracetamol added (11). With paracetamol being rapidly absorbed in the small intestine, gastric emptying forms the rate-limiting step determining the appearance rate of paracetamol in the circulation. Peak plasma paracetamol concentrations are typically reached after 30-60 min following ingestion with a $t^{1} / 2$ of $\sim 2 \mathrm{~h}$ (23). We used plasma paracetamol appearance in the circulation as a marker of gastric emptying as applied previously in our laboratory $(14,23)$ as well as others $(15,17)$.

Plasma analysis

Plasma glucose and insulin concentrations were analyzed using commercially available kits (Glucose HK CP, Horiba ABX Diagnostics, France, Ref: AA11A01667, and Human Insulinspecific (RIA), Merck Millipore, Germany, Cat \#: HI-14K, respectively). Plasma (100 $\mu \mathrm{L}$ ) for amino acid analyses was deproteinized on ice with 5-sulphosalicylic acid, mixed and the clear supernatant was collected after centrifugation. Amino acid profiles were determined using ultra-performance liquid chromatography tandem mass spectrometry (UPLC-MS/MS) as described previously (27). Plasma paracetamol concentrations were analyzed with an acetaminophen assay kit (K991598, Roche, Basel, Switzerland) with the COBAS-Integra 800 immuno-assay analyzer. Briefly, acetaminophen is hydrolyzed to $p$-aminophenol and acetate. The $\mathrm{p}$-aminophenol is then converted to an indophenol by enzymatic reaction. The production of indophenol is colorimetrically analyzed and is directly proportional to acetaminophen concentration in plasma.

\section{Statistics}

The study was powered according to an anticipated difference in plasma leucine peak concentrations. Based on previously published data $(14,18)$, we expected the mean effect difference in peak plasma leucine concentrations to be approximately $30 \mu \mathrm{mol} \cdot \mathrm{L}^{-1}$ and the standard deviation to be approximately $25 \mu \mathrm{mol} \cdot \mathrm{L}^{-1}$. A sample size of 8 subjects was calculated using a power of $80 \%(1-\beta=0.8)$ and a two-sided significance level of $5 \%$ ( $\alpha=$ 0.05). All data are expressed as mean + SEM. Time-dependent variables (i.e., plasma glucose and insulin concentrations, plasma amino acid concentrations, plasma L- $\left[1-{ }^{13} \mathrm{C}\right]-$ phenylalanine enrichments and plasma paracetamol concentrations) were analyzed by twofactor repeated measures ANOVA. The analysis was carried out for the period starting at the time of protein ingestion, between $t=0$ and $300 \mathrm{~min}$. Upon identification of a significant interaction, Bonferroni post hoc testing was used to identify time points in which the treatments were different. Differences in treatment-dependent variables, such as area under the curve (AUC), were analyzed using Student's paired t-test. Pearson's $r$ product moment correlation was used to examine the linear relationship between plasma leucine amino acid 
Chapter 6

and paracetamol AUC for each test. Statistical significance was set at $P<0.05$. All calculations were performed using SPSS 21.0 (IBM, Chicago, Illinois, USA). 


\section{Results}

Plasma glucose and insulin concentrations

Plasma glucose concentrations (Figure 6.1A) decreased slightly following protein intake in both treatments (time effect, $P<0.01$ ). Plasma insulin concentrations (Figure 6.1B) increased following protein ingestion in both treatments (time effect, $P<0.01$ ). The changes in plasma glucose and insulin concentrations were different between the sitting and lying treatments (time $\times$ treatment interaction, $P<0.05$ ). Peak post-prandial insulin concentrations were reached at $t=15 \mathrm{~min}$ and tended to be lower in the lying vs sitting treatment ( $20 \pm 5$ vs 25 $\pm 3 \mathrm{mU} \cdot \mathrm{L}^{-1}, P=0.09$

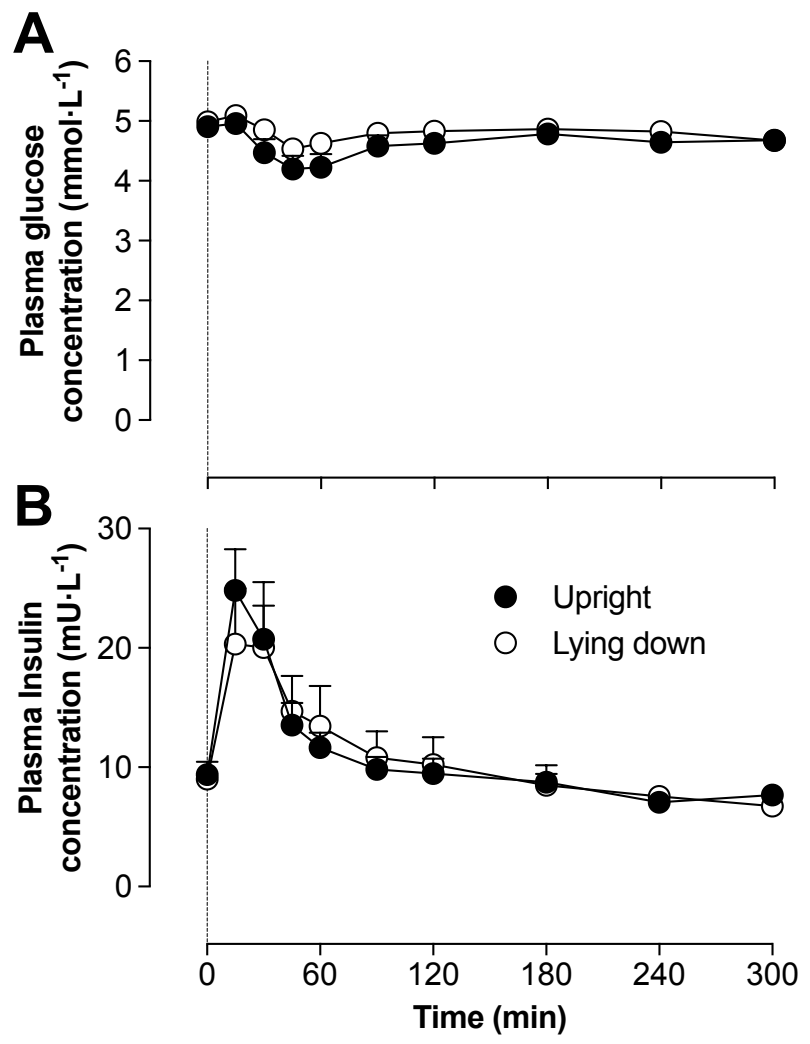

Figure 6.1 Mean (+SEM) plasma glucose $\left(\mathrm{mmol} \cdot \mathrm{L}^{-1} ; \mathrm{A}\right)$ and insulin $\left(\mathrm{mU} \cdot \mathrm{L}^{-1} ; \mathrm{B}\right)$ concentrations after protein ingestion while seated (Upright; $n=8$ ) and while lying in a supine body position (Lying down; $n=8$ ). The data were analyzed with a two-way repeated-measures (treatment $\times$ time) ANOVA. Glucose: time effect: $P<0.05$; time $\times$ treatment interaction: $P<0.01$. Insulin: time effect: $P<0.01$; time $\times$ treatment interaction: $P<0.05$.

Plasma amino acid responses

Plasma leucine (Figure 6.2A), total essential (Figure 6.2C) and total non-essential (Figure 6.2E) amino acid concentrations increased following protein ingestion in both treatments compared with baseline $(P<0.01)$. Plasma leucine and total essential amino acid 
Chapter 6

concentrations showed an attenuated rise in the lying compared with the sitting treatment (time $\times$ treatment, $P<0.05$ ), with concentrations being significantly lower between $t=30$ $45 \mathrm{~min}$ in the lying compared with sitting position $(P<0.05)$. Overall plasma leucine availability, assessed using AUC analysis over $300 \mathrm{~min}$, tended to be lower in the lying compared with sitting treatment $(P=0.05)$. No significant differences in overall plasma essential and non-essential availability over 300 min were observed after protein ingestion between treatments $(P>0.05)$. After protein ingestion, plasma $\mathrm{L}-\left[1-{ }^{13} \mathrm{C}\right]$-phenylalanine enrichments (Figure 6.3), originating from the ingested protein, increased rapidly in both treatments reaching maximal values of $2.0 \pm 0.2 \mathrm{MPE}$ at $t=30 \mathrm{~min}$ in the sitting treatment and $1.9 \pm 0.1 \mathrm{MPE}$ at $t=60 \mathrm{~min}$ in the supine lying treatment (main effect for time, $\mathrm{P}<0.01$, time $\times$ treatment interaction, $P<0.01$ ). 


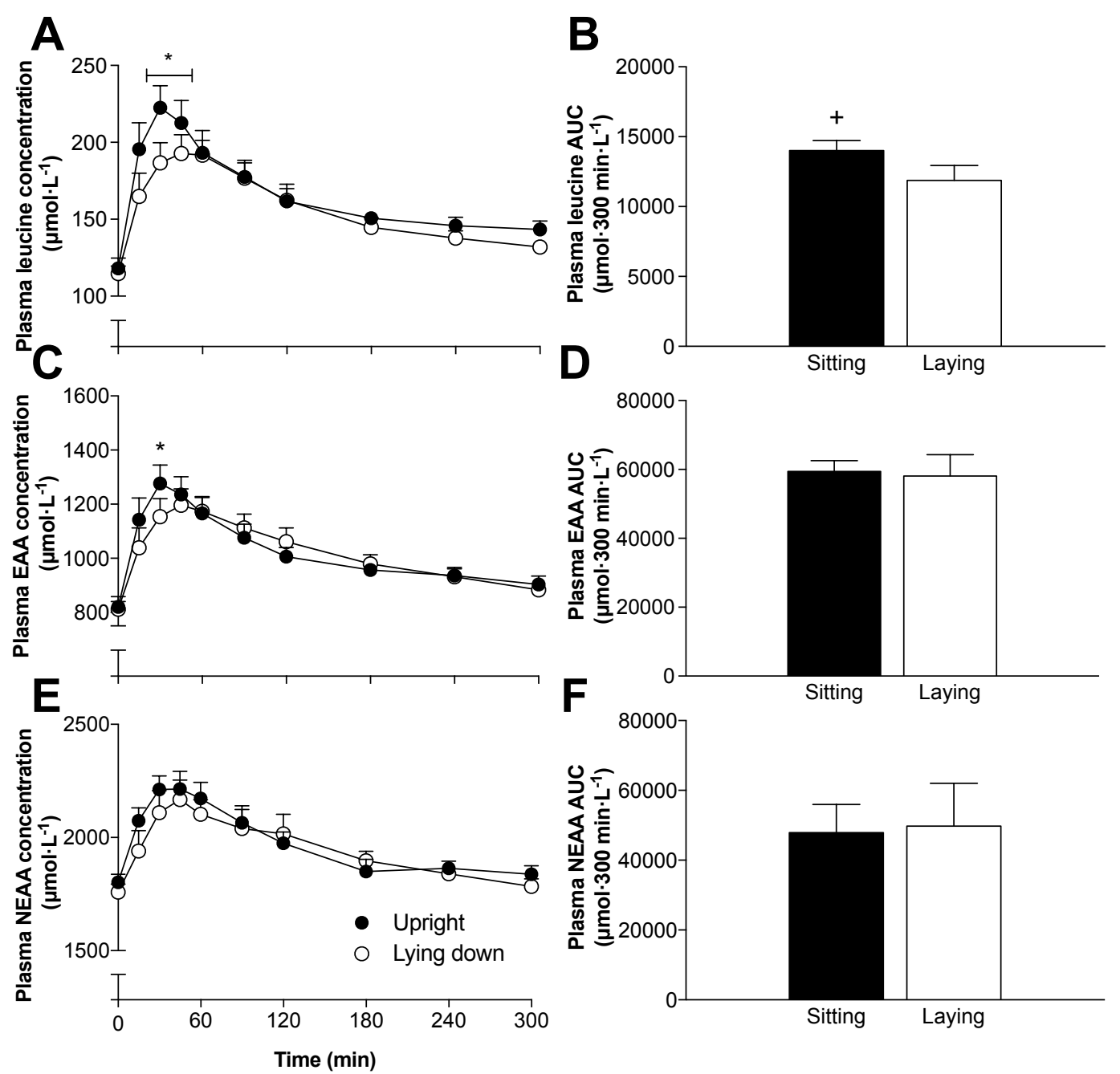

Figure 6.2 Mean (+SEM) plasma leucine (A), essential (EAAs; B) and non-essential (NEAAs; C) amino acid concentrations $\left(\mu \mathrm{mol} \cdot \mathrm{L}^{-1}\right)$ after protein ingestion in a seated (Upright; $n=8$ ) and while lying in a supine boy position (Lying down; $n=8$ ). The data were analyzed with a two-way repeated-measures (treatment $\times$ time) ANOVA. Leucine: time effect: $P<0.01$; time $\times$ treatment interaction: $P<0.05$. EAAs: time effect: $P<0.01$; time $x$ treatment interaction: $P<0.05$. NEAAs: time effect: $P<0.01$; time $\times$ treatment interaction: $P>0.05$. Area under the curve over $300 \mathrm{~min}$ for plasma leucine (B), EAA (D), and NEAA (F, $\left.\mu \mathrm{mol} \cdot 300 \mathrm{~min} \cdot \mathrm{L}^{-1}\right)$ analyzed with a Student's paired t-test. ${ }^{*}$ Significant differences $(P<0.05)$ between treatments within each time point. + Trend for a difference between treatments $(P<0.10)$.

\section{Gastric Emptying}

Plasma paracetamol concentrations (Figure 6.4) increased following protein ingestion in both treatments $(P<0.05)$. Peak paracetamol concentrations reached $11.2 \pm 0.8 \mathrm{mg} \cdot \mathrm{L}^{-1}$ at $t$ $=45 \mathrm{~min}$ in the sitting treatment and $9.3 \pm 0.6 \mathrm{mg} \cdot \mathrm{L}^{-1}$ at $t=90 \mathrm{~min}(P<0.05)$ in the supine lying treatment. Gastric emptying during the early post-prandial phase, assessed by paracetamol AUC between $t=0-60$ min was $23 \pm 7 \%$ lower in the lying compared with sitting treatment $\left(521 \pm 45\right.$ vs $\left.395 \pm 42 \mathrm{mg} \cdot 300 \mathrm{~min} \cdot \mathrm{L}^{-1} ; P<0.01\right)$. When assessed over the entire $300 \mathrm{~min}$ post-prandial period, paracetamol AUC no longer differed between treatments $(P>0.05)$. 


\section{Chapter 6}

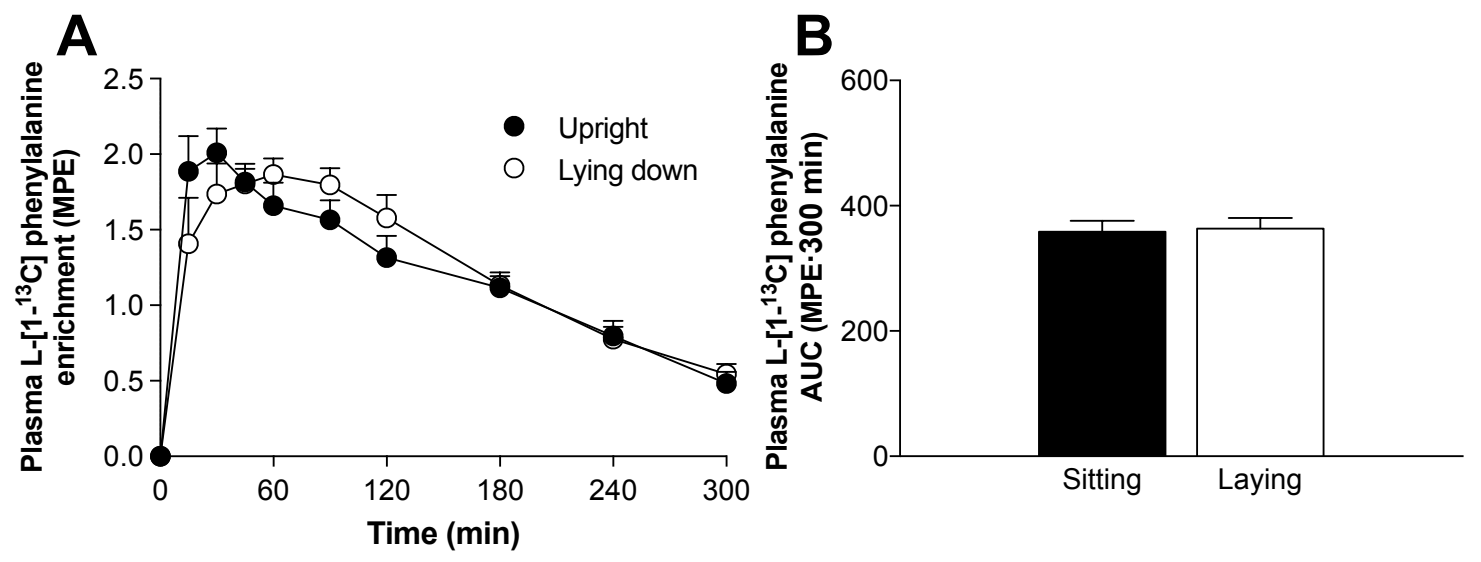

Figure 6.3 Mean (+SEM) plasma L-[1-13C]-phenylalanine enrichment (MPE) after protein ingestion in a seated (Upright; $n=8$ ) and while lying in a supine body position (Lying down; $n=8$ ). The data were analyzed with a two-way repeated-measures (treatment $\times$ time) ANOVA: Time effect: $P<0.01$; time $\times$ treatment interaction: $P$ $<0.01$. Area under the curve over $300 \mathrm{~min}$ (B, MPE.300 min) analyzed with a Student's paired t-test.

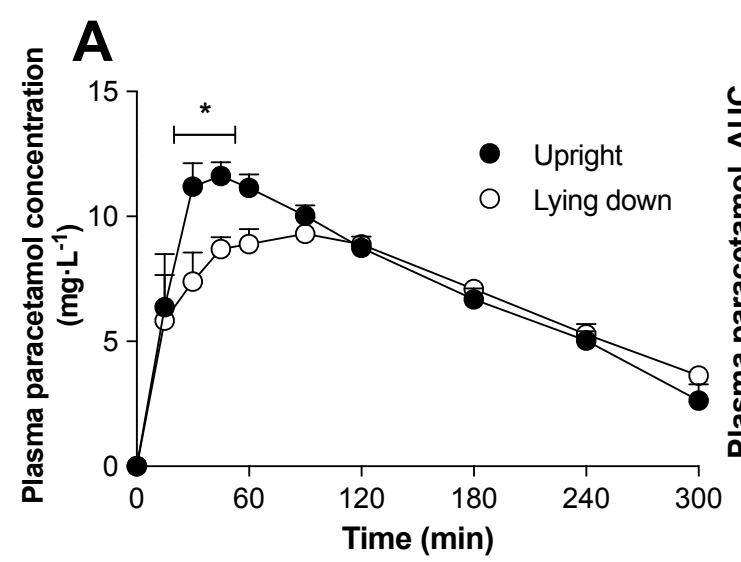

B

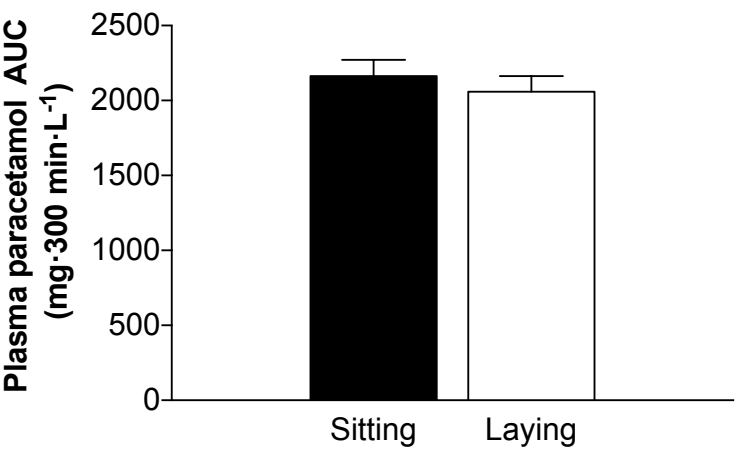

Figure 6.4 Mean (+SEM) plasma paracetamol concentrations $\left(m g \cdot L^{-1}\right)$ after protein ingestion in a seated (Upright; $n=8$ ) and while lying in a supine body position (Lying down; $n=8$ ). The data were analyzed with a two-way repeated-measures (treatment $\times$ time) ANOVA: Time effect: $P<0.01$; time $\times$ treatment interaction: $P$ $<0.01$. Area under the curve over $300 \mathrm{~min}\left(B, \mathrm{mg} \cdot 300 \mathrm{~min} \cdot \mathrm{L}^{-1}\right)$ inset and analyzed with a Student's paired t-test. *Significant differences $(P<0.05)$ between treatments within each time point. 


\section{Discussion}

In the present study, we observed that gastric emptying rate was accelerated when protein was ingested in an upright sitting versus supine lying body position. The post-prandial rise in circulating leucine concentrations was greater when protein was ingested in the upright sitting position, which was accompanied by a trend for greater overall plasma leucine availability when compared to the lying position.

The postprandial rise in plasma essential amino acids, and leucine in particular, is a key factor for driving the stimulation of postprandial muscle protein synthesis $(8,26)$. In the present study, ingestion of a meal-like amount of protein rapidly increased plasma insulin (Figure 6.1B), essential amino acids (Figure 6.2C), and leucine (Figure 6.2A) concentrations. The post-prandial rise in plasma amino acid availability was attributed to the appearance of dietary protein-derived amino acids in the circulation, as evidenced by the post-prandial rise in both plasma phenylalanine concentration and L- $\left[1-{ }^{13} \mathrm{C}\right]$-phenylalanine enrichments (Figure 6.3A). When protein was ingested in the sitting position, plasma essential amino acid concentrations reached peak levels of $1277 \pm 69 \mu \mathrm{mol} \cdot \mathrm{L}^{-1}$, with plasma leucine concentrations reaching $223 \pm 14 \mu \mathrm{mol} \cdot \mathrm{L}^{-1}$. Such post-prandial increases in plasma essential amino acid concentrations, and plasma leucine in particular, have previously been shown to increase muscle protein synthesis rates by 30-100 \% when compared to basal, postabsorptive muscle protein synthesis rates $(2,5,13,28,29)$.

The same, meal-like amount of protein ingested in the lying down position resulted in a blunted post-prandial rise in plasma insulin (Figure 6.1B), total essential amino acids (Figure 6.2C) and leucine (Figure 6.2A) concentrations when compared to protein intake in an upright sitting position. After protein ingestion in the lying down position, peak plasma leucine concentration reached $193 \pm 12 \mu \mathrm{mol} \cdot \mathrm{L}^{-1}$, which was significantly lower when compared with post-prandial peak plasma leucine concentrations observed following protein ingestion in a seated position. In accordance, plasma leucine availability over the entire $5 \mathrm{~h}$ post-prandial period was $15 \pm 6 \%$ less following protein ingestion in the lying versus upright, seated position $(P=0.05)$. The attenuated rise in post-prandial plasma leucine availability observed between the upright sitting and lying down positions is in line with previous proof-of-principle data from our lab comparing plasma amino acid availability after protein ingestion in an upright sitting versus head-tilted down body position (14). The blunted post-prandial rise in plasma leucine and total essential amino acid concentrations after protein ingestion in a lying down position would unlikely suffice to induce a measurable post-prandial increase in muscle protein synthesis rates as demonstrated in previous work $(28,29)$.

The modulation of post-prandial plasma leucine availability has also been demonstrated in various studies assessing protein digestion and absorption kinetics and muscle protein synthesis rates after ingestion of different protein amounts $(19,28,29)$, types $(16,18)$ and meals with different macronutrient compositions (13). By combining the ingestion of 
intrinsically L- $\left[1-{ }^{13} \mathrm{C}\right]$-phenylalanine labeled protein with the continuous intravenous L-[ring${ }^{2} \mathrm{H}_{5}$-phenylalanine infusion, some of these studies were able to demonstrate that a greater first pass splanchnic extraction of dietary protein-derived amino acids was likely responsible for the attenuated postprandial rise in plasma amino acid availability $(13,16,18)$. In the present study, we provided our subjects with intrinsically L-[1- $\left.{ }^{13} \mathrm{C}\right]$-phenylalanine labeled protein. By collecting blood samples over a $5 \mathrm{~h}$ post-prandial period and measuring both plasma phenylalanine concentrations as well as $\mathrm{L}-\left[1-{ }^{13} \mathrm{C}\right]$-phenylalanine enrichments, we were able to compare the post-prandial rise in dietary protein-derived amino acid availability in the circulation, providing insight into dietary protein digestion and amino acid absorption kinetics (24). We observed a modulation in the temporal pattern of dietary protein-derived amino acid availability with protein ingestion in the sitting as opposed to lying position, resulting in a more rapid release of dietary protein-derived amino acids without changing overall plasma availability assessed over the entire $5 \mathrm{~h}$ post-prandial period (Figure 6.3). These findings indicate that dietary protein-derived amino acid absorption is accelerated when protein is ingested in a seated compared with lying position, resulting in a greater post-prandial rise in plasma essential amino acid and leucine concentrations.

The more rapid release of dietary protein-derived amino acids into the circulation following protein ingested in a seated vs lying down position may be attributed to a delay in gastric emptying rate in the lying position. Therefore, we also assessed gastric emptying rates by measuring the increase in plasma paracetamol concentrations following the combined ingestion of protein with $1.5 \mathrm{~g}$ paracetamol $(11,14,23)$. Peak plasma paracetamol concentrations were substantially higher in the seated vs lying down position (11.6 \pm 0.5 vs $9.3 \pm 0.6 \mathrm{mg} \cdot \mathrm{L}^{-1}$, respectively) and were reached 45 min earlier when protein was ingested in the sitting position compared to the lying position (Figure 6.4A). In accordance, AUC analysis of plasma paracetamol concentrations over the first 60 min after protein ingestion revealed a substantially higher gastric emptying rate in the sitting compared with lying position (Figure 6.4B). Furthermore, we observed a significant positive correlation between plasma paracetamol and leucine AUC during the early post-prandial period ( $t=0-60 \mathrm{~min} ; r$ $=0.53 ; P<0.05)$. Altogether, these data show that gastric emptying rates are $23 \%$ slower when protein is ingested in a lying body position, resulting in an attenuated post-prandial rise in circulating plasma amino acid concentrations. Of course, we cannot exclude that other factors, such as changes in splanchnic blood flow, may contribute to the observed differences in post-prandial protein handling following food intake in an upright sitting or supine position. These differences in post-prandial amino acid availability are similar to differences observed between slowly vs more rapidly digestible proteins $(16,18)$, implying that body position can strongly modulate post-prandial protein handling in vivo in humans. The present findings may be of relevance to various settings of disuse atrophy. Disuse atrophy has been partly attributed to a reduced sensitivity of the muscle protein synthetic response to the post-prandial rise in plasma amino acid concentrations, and leucine in particular $(12,25)$. In the present study, we observed that protein ingestion in a lying body 
position results in an attenuated rise and overall availability of plasma leucine. Therefore, feeding bedridden patients in a lying down as opposed to a normal upright sitting position may attenuate the post-prandial rise in plasma amino acid concentrations, contributing to a diminished anabolic response to feeding in these patients. Proper upright body position during and after feeding may be a pre-requisite to maximize post-prandial muscle protein accretion and, as such, compensate for anabolic resistance.

In conclusion, protein ingestion in an upright sitting as opposed to a lying down position accelerates gastric emptying rate, accelerates dietary protein-derived amino acid absorption, and increases the post-prandial rise in plasma amino acid concentrations. Therefore, an upright body position during and after feeding is recommended when aiming to optimize post-prandial muscle protein accretion. 


\section{References}

1. Bax M-L, Aubry L, Ferreira C, Daudin J-D, Gatellier P, Rémond D, Santé-Lhoutellier V. Cooking temperature is a key determinant of in vitro meat protein digestion rate: investigation of underlying mechanisms. J Agric Food Chem 60: 2569-2576, 2012.

2. Burd NA, Gorissen SH, van Vliet S, Snijders T, van Loon LJ. Differences in postprandial protein handling after beef compared with milk ingestion during postexercise recovery: a randomized controlled trial. Am J Clin Nutr 102: 828-836, 2015.

3. Calbet JAL, Holst JJ. Gastric emptying, gastric secretion and enterogastrone response after administration of milk proteins or their peptide hydrolysates in humans. Eur J Nutr 43: 127-139, 2004.

4. Churchward-Venne TA, Burd NA, Mitchell CJ, West DWD, Philp A, Marcotte GR, Baker SK, Baar K, Phillips SM. Supplementation of a suboptimal protein dose with leucine or essential amino acids: effects on myofibrillar protein synthesis at rest and following resistance exercise in men. J Physiol 590: 27512765, 2012.

5. Churchward-Venne TA, Snijders T, Linkens AMA, Hamer HM, van Kranenburg J, van Loon LJC. Ingestion of Casein in a Milk Matrix Modulates Dietary Protein Digestion and Absorption Kinetics but Does Not Modulate Postprandial Muscle Protein Synthesis in Older Men. J Nutr 145: 1438-1445, 2015.

6. Dangin M, Boirie Y, Garcia-Rodenas C, Gachon P, Fauquant J, Callier P, Ballèvre O, Beaufrere B. The digestion rate of protein is an independent regulating factor of postprandial protein retention. Am $J$ Physiol Endocrinol Metab 280: E340-8, 2001.

7. Dickinson JM, Drummond MJ, Coben JR, Volpi E, Rasmussen BB. Aging differentially affects human skeletal muscle amino acid transporter expression when essential amino acids are ingested after exercise. Clin Nutr 32: 273-280, 2013.

8. Dreyer HC, Drummond MJ, Pennings B, Fujita S, Glynn EL, Chinkes DL, Dhanani S, Volpi E, Rasmussen BB. Leucine-enriched essential amino acid and carbohydrate ingestion following resistance exercise enhances mTOR signaling and protein synthesis in human muscle. Am J Physiol Endocrinol Metab 294: E392-400, 2008.

9. Dreyer HC, Volpi E. Role of protein and amino acids in the pathophysiology and treatment of sarcopenia. J Am Coll Nutr 24: 140S-145S, 2005.

10. Fry CS, Drummond MJ, Glynn EL, Dickinson JM, Gundermann DM, Timmerman KL, Walker DK, Dhanani S, Volpi E, Rasmussen BB. Aging impairs contraction-induced human skeletal muscle mTORC1 signaling and protein synthesis. Skelet Muscle 1: 11, 2011.

11. Glerup H, Bluhme H, Villadsen GE, Rasmussen K, Ejskjaer N, Dahlerup JF. Gastric emptying: a comparison of three methods. Scand J Gastroenterol 42: 1182-1186, 2007.

12. Glover El, Phillips SM, Oates BR, Tang JE, Tarnopolsky MA, Selby A, Smith K, Rennie MJ. Immobilization induces anabolic resistance in human myofibrillar protein synthesis with low and high dose amino acid infusion. J Physiol 586: 6049-6061, 2008.

13. Gorissen SHM, Burd NA, Hamer HM, Gijsen AP, Groen BB, van Loon LJC. Carbohydrate coingestion delays dietary protein digestion and absorption but does not modulate postprandial muscle protein accretion. J Clin Endocrinol Metab 99: 2250-2258, 2014.

14. Holwerda AM, Lenaerts K, Bierau J, van Loon LJC. Body Position Modulates Gastric Emptying and Affects the Post-Prandial Rise in Plasma Amino Acid Concentrations Following Protein Ingestion in Humans. Nutrients 8, 2016.

15. Horowitz M, Flint A, Jones KL, Hindsberger C, Rasmussen MF, Kapitza C, Doran S, Jax T, Zdravkovic M, Chapman IM. Effect of the once-daily human GLP-1 analogue liraglutide on appetite, energy intake, energy expenditure and gastric emptying in type 2 diabetes. Diabetes Res Clin Pract 97: 258-266, 2012.

16. Koopman R, Crombach N, Gijsen AP, Walrand S, Fauquant J, Kies AK, Lemosquet S, Saris WHM Boirie Y, van Loon LJC. Ingestion of a protein hydrolysate is accompanied by an accelerated in vivo digestion and absorption rate when compared with its intact protein. Am J Clin Nutr 90: 106-115, 2009.

17. Panahi S, Khoury El D, Kubant R, Akhavan T, Luhovyy BL, Goff HD, Anderson GH. Mechanism of action of whole milk and its components on glycemic control in healthy young men. J Nutr Biochem 25: 1124 1131, 2014.

18. Pennings B, Boirie $\mathbf{Y}$, Senden JMG, Gijsen AP, Kuipers H, van Loon LJC. Whey protein stimulates postprandial muscle protein accretion more effectively than do casein and casein hydrolysate in older men. Am J Clin Nutr 93: 997-1005, 2011. 
19. Pennings B, Groen B, de Lange A, Gijsen AP, Zorenc AH, Senden JMG, van Loon LJC. Amino acid absorption and subsequent muscle protein accretion following graded intakes of whey protein in elderly men. Am J Physiol Endocrinol Metab 302: E992-9, 2012.

20. Pennings B, Groen BBL, van Dijk J-W, de Lange A, Kiskini A, Kuklinski M, Senden JMG, van Loon LJC. Minced beef is more rapidly digested and absorbed than beef steak, resulting in greater postprandial protein retention in older men. Am J Clin Nutr 98: 121-128, 2013.

21. Rasmussen BB, Fujita S, Wolfe RR, Mittendorfer B, Roy M, Rowe VL, Volpi E. Insulin resistance of muscle protein metabolism in aging. FASEB J 20: 768-769, 2006.

22. Soop M, Nehra V, Henderson GC, Boirie Y, Ford GC, Nair KS. Coingestion of whey protein and casein in a mixed meal: demonstration of a more sustained anabolic effect of casein. Am J Physiol Endocrinol Metab 303: E152-62, 2012.

23. van Can J, Sloth B, Jensen CB, Flint A, Blaak EE, Saris WHM. Effects of the once-daily GLP-1 analog liraglutide on gastric emptying, glycemic parameters, appetite and energy metabolism in obese, nondiabetic adults. Int J Obes 38: 784-793, 2014

24. van Loon LJC, Boirie $Y$, Gijsen AP, Fauquant J, de Roos AL, Kies AK, Lemosquet S, Saris WHM, Koopman $\mathbf{R}$. The production of intrinsically labeled milk protein provides a functional tool for human nutrition research. J Dairy Sci 92: 4812-4822, 2009.

25. Wall BT, Dirks ML, Snijders T, van Dijk J-W, Fritsch M, Verdijk LB, van Loon LJC. Short-term muscle disuse lowers myofibrillar protein synthesis rates and induces anabolic resistance to protein ingestion. Am J Physiol Endocrinol Metab 310: E137-47, 2016.

26. Wall BT, Hamer HM, de Lange A, Kiskini A, Groen BBL, Senden JMG, Gijsen AP, Verdijk LB, van Loon LJC. Leucine co-ingestion improves post-prandial muscle protein accretion in elderly men. Clin Nutr 32: 412-419, 2013.

27. Waterval WAH, Scheijen JLJM, Ortmans-Ploemen MMJC, Habets-van der Poel CD, Bierau J. Quantitative UPLC-MS/MS analysis of underivatised amino acids in body fluids is a reliable tool for the diagnosis and follow-up of patients with inborn errors of metabolism. Clin Chim Acta 407: 36-42, 2009.

28. Yang Y, Breen L, Burd NA, Hector AJ, Churchward-Venne TA, Josse AR, Tarnopolsky MA, Phillips SM. Resistance exercise enhances myofibrillar protein synthesis with graded intakes of whey protein in older men. Br J Nutr 108: 1780-1788, 2012.

29. Yang Y, Churchward-Venne TA, Burd NA, Breen L, Tarnopolsky MA, Phillips SM. Myofibrillar protein synthesis following ingestion of soy protein isolate at rest and after resistance exercise in elderly men. Nutr Metab 9: 57, 2012. 



\section{Chapter 7}

Daily resistance-type exercise stimulates muscle protein synthesis in vivo in young men

Andrew M. Holwerda, Kevin J. M. Paulussen, Maarten Overkamp, Joey S. J. Smeets, Annemie P. Gijsen, Joy P. B. Goessens, Lex B. Verdijk, and Luc J. C. van Loon

The Journal of Applied Physiology, 124(1), 66-75. 2018. 
Chapter 7

\section{Abstract}

Background Resistance-type exercise increases muscle protein synthesis rates during acute post-exercise recovery. The impact of resistance-type exercise training on (local) muscle protein synthesis rates under free-living conditions on a dayto-day basis remains unclear.

Objective We determined the impact of daily unilateral resistance-type exercise on local myofibrillar protein synthesis rates during a 3-day period.

Methods Twelve healthy young men (22 $\pm 1 \mathrm{y})$ were recruited to participate in this study where they performed daily, unilateral resistance-type exercise during a 3-day intervention period. Two days before the exercise training subjects ingested $400 \mathrm{~mL}$ deuterated water $\left({ }^{2} \mathrm{H}_{2} \mathrm{O}\right)$. Additional $50 \mathrm{~mL}$ doses of deuterated water were ingested daily during the training period. Saliva and blood samples were collected daily to assess body water and amino acid precursor deuterium enrichments, respectively. Muscle tissue biopsies were collected before and after the 3 days of unilateral resistance-type exercise training from both the exercised and the nonexercised, control leg for the assessment of muscle protein synthesis rates.

Results Deuterated water dosing resulted in a steady-state body water enrichment of $0.70 \pm 0.03 \%$. Intramuscular free $\left[{ }^{2} \mathrm{H}\right]$-alanine enrichment increased up to 1.84 \pm 0.06 mole percent excess (MPE) before the exercise training and did not change in both the exercised and control leg during the 3 subsequent exercise training days $(2.11 \pm 0.11$ and $2.19 \pm 0.12 \mathrm{MPE}$, respectively; $P>$ $0.05)$. Muscle protein synthesis rates averaged $1.984 \pm 0.118$ and $1.642 \pm$ $0.089 \% \cdot d^{-1}$ in the exercised vs. nonexercised, control leg when assessed over the entire 3-day period $(P<0.05)$.

Conclusions Daily resistance-type exercise stimulates (local) muscle protein synthesis in vivo in humans. 


\section{Introduction}

Skeletal muscle mass is regulated by the net balance between muscle protein synthesis and breakdown rates, which typically show a turnover rate of 1-2\% per day (27). Physical activity and food ingestion represent two major anabolic stimuli that increase muscle protein synthesis rates. A single session of resistance-type exercise increases muscle protein turnover $(6,14,39)$ and sensitizes skeletal muscle tissue to the anabolic properties of protein ingestion $(13,35,38)$. Protein ingestion increases plasma amino acid availability, which further augments the acute post-exercise increase in muscle protein synthesis rates $(17,18$, $37,49,53)$. Whereas the synergistic effects of resistance-type exercise and protein ingestion have been well established in acute post-exercise settings, it remains to be established how such acute findings align with more long-term anabolic responses to exercise.

Contemporary stable amino acid infusion techniques combined with muscle biopsy sampling allows for acute in vivo assessment of muscle protein synthesis rates in humans $(9,43,51)$. However, subjects are restricted to the laboratory environment during amino acid tracer infusions and are typically tested under rested and fasted conditions to ensure a high level of control during the laboratory assessment. Furthermore, acute infusion protocols may lose reliability after more than $12 \mathrm{~h}$ due to recycling of the infused amino acid tracer between protein and precursor pools $(46,50)$. Consequently, it has been debated to what extent the acute post-exercise muscle protein synthetic response to a single bout of exercise can be predictive of the absolute changes in skeletal muscle mass that can be observed during more long-term exercise training interventions $(3,32,34)$.

Recently, oral deuterated water $\left({ }^{2} \mathrm{H}_{2} \mathrm{O}\right)$ dosing has re-emerged in the field as a method to assess muscle protein synthesis rates over a period of days or even weeks $(21,45)$. Ingestion of deuterated water enriches the body water pool with deuterium, allowing for endogenous deuterium labeling of the non-essential amino acid, alanine. The deuterium-labeled alanine is synthesized into muscle proteins, which can be detected in muscle biopsy samples and used to calculate muscle protein synthesis rates $(44,45,57)$. Test participants are able to remain in their free-living environment, providing the opportunity to incorporate important anabolic factors such as dietary protein intake, habitual physical activity, exercise, hormonal responses and diurnal variations into the assessment of daily muscle protein synthesis rates. For example, Wilkinson et al. and Brooks et al. have recently applied the deuterated water method in humans to assess temporal patterns of the muscle anabolic response to resistance-type exercise training over 8 days (57) and 6 weeks (8), respectively. As such, the deuterated water method appears to represent a valuable tool to better understand the how muscle protein synthesis rates are impacted under more natural settings, which may serve to better predict changes in skeletal muscle mass observed under a variety of conditions.

Here, we applied oral deuterated water dosing methods to determine the impact of resistance-type exercise training on local muscle protein synthesis rates over a three-day period. In order to test our hypothesis that resistance-type exercise training increases muscle 


\section{Chapter 7}

protein synthesis rates over multiple days, we recruited 12 young men $(21 \pm 1 \mathrm{y})$ for testing. All subjects performed unilateral resistance-type exercise every day during a three-day intervention period. Subjects ingested small amounts of deuterated water each day throughout the experiment to enrich the body water pool. Saliva and blood samples were collected to assess body water deuterium and plasma free $\left[{ }^{2} \mathrm{H}\right]$-alanine enrichments, respectively. Muscle tissue biopsies were collected before and after the three days of unilateral resistance-type exercise training from the exercised as well as the non-exercised, control leg for the assessment of local muscle protein synthesis rates. 


\section{Materials and methods}

\section{Subjects}

A total of 12 healthy young men $\left(22 \pm 1 \mathrm{y}, 23.9 \pm 0.5 \mathrm{~kg} \cdot \mathrm{m}^{-2}\right)$ were recruited to participate in the present study. Subject characteristics are presented in Table 7.1. All subjects were screened for inclusion by filling in a medical questionnaire. Upon inclusion, all subjects were performing activities of daily living, but were not participating in any structured exercise program totaling more than $4 \mathrm{~h}$ of exercise per week. All subjects were informed of the nature and possible risks of the experimental procedures before their written informed consent was obtained. The study was approved by the Medical Ethical Committee of the Maastricht University Medical Centre, The Netherlands, and conformed to standards for the use of human subjects in research as outlined in the most recent version of the Helsinki Declaration. The study was registered at Netherlands Trial Register as NTR5099.

Table 7.1 Subjects' baseline characteristics of healthy young men who completed unilateral resistance-type exercise on 3 consecutive experimental test day ${ }^{1}$

\begin{tabular}{lc}
\hline & $\boldsymbol{n}=12$ \\
\hline Age, $\mathrm{y}$ & $22 \pm 1$ \\
Weight, $\mathrm{kg}$ & $77.7 \pm 2.7$ \\
Height, $\mathrm{cm}$ & $180 \pm 2$ \\
$\mathrm{BMI}, \mathrm{kg} \cdot \mathrm{m}^{-2}$ & $23.9 \pm 0.5$ \\
LBM, $\mathrm{kg}$ & $63.2 \pm 1.9$ \\
Body fat, \% & $16 \pm 1$ \\
Unilateral Leg Extension 1RM, kg & $72 \pm 4$ \\
Unilateral Leg Press $1 \mathrm{RM}, \mathrm{kg}$ & $133 \pm 7$ \\
Protein intake, $\mathrm{g} \cdot \mathrm{kg}^{-1} \cdot \mathrm{d}^{-1}$ & $1.7 \pm 0.2$ \\
Step count, steps $\cdot \mathrm{d}^{-1}$ & $7266 \pm 686$ \\
\hline
\end{tabular}

${ }^{1}$ Values are expressed as means \pm SEM. $n=12 ; B M I$, body mass index. LBM, lean body mass. 1 RM, one repetition maximum.

\section{Pretesting}

During the initial screening visit, subjects were familiarized with the study exercise program and had their maximal strength (1RM) estimated on the exercise machines. Subjects first performed a 5 min cycling exercise warm-up at $150 \mathrm{~W}$ before completing an estimation of their 1RM (one repetition maximum) on the leg press and leg extension exercises using the multiple repetitions testing procedure (31). Subjects completed the strength testing with the leg (dominant or non-dominant) that was randomly chosen to complete the exercise program during the study protocol. For each exercise machine, subjects performed 10 submaximal, or warm-up repetitions to become familiarized with the equipment and to have lifting technique critiqued and corrected. Subjects then performed sets at progressively 
increasing loads until failing to complete a valid repetition, judged by their inability to complete the full range of motion for an exercise. Ideally, subjects failed within 3-6 repetitions during the last and heaviest set. A 2 min resting period between subsequent attempts was allowed. The pretesting and experimental trials were separated by a period of at least 7 days.

\section{Diet and physical activity}

All subjects were instructed to refrain from any exhaustive physical activity and to keep their diet as consistent as possible $72 \mathrm{~h}$ prior to the trial. Starting on the first test day, subjects began recording their diet and physical activity in diaries and continued to do so for the remaining test days. Step count was assessed during the experiment using an accelerometer (Actical, Philips Respironics, The Netherlands). Upon arrival to the laboratory for the deuterated water dosing day (Day 2), subjects started wearing the accelerometer on their right hip at the mid clavicular line for the duration of the experiment.

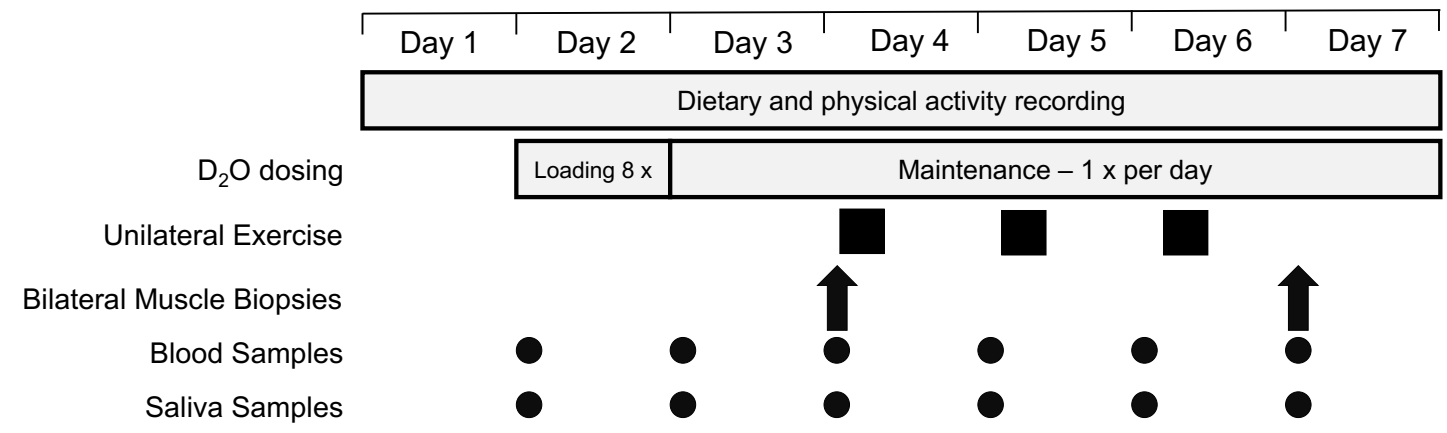

Figure 7.1 Graphical representation of the experimental protocol.

\section{Experimental Protocol}

The study protocol (Figure 7.1) was designed to assess how daily resistance-type exercise training impacts muscle protein synthesis rates over multiple days while participating in normal daily physical activities and consuming a normal diet. The study protocol consisted of 7 consecutive test days. In order to measure mixed muscle protein synthesis rates over multiple days, subjects underwent a deuterium oxide dosing protocol. The deuterated water dosing protocol (described below) was initiated on day 2 and was continued over the last 6 $\mathrm{d}$ of the experimental protocol. The dosing protocol was designed to achieve and maintain 0.8-1.0\% body water deuterium enrichment between days 3 and 7 . Subjects reported to the lab at $1000 \mathrm{~h}$ on test day 4 to have one muscle biopsy collected from each leg. Following the muscle biopsies, subjects completed the first of three unilateral resistance-type exercise sessions (described below). After completing each exercise session, test subjects ingested $30 \mathrm{~g}$ whey protein dissolved in water with an added $1.5 \mathrm{~mL}$ vanilla flavour. Subjects then left 
the lab and were instructed to maintain their normal routine, but refrain from any exhaustive physical activity. Subjects returned to the lab between $0900-1100 \mathrm{~h}$ on days 5 and 6 to complete the final two exercise sessions. Subjects returned to the lab at $1000 \mathrm{~h}$ on day 7 when the final muscle biopsies were collected from each leg signifying the end of the research protocol.

Blood samples were collected in EDTA containing tubes and centrifuged at $1000 \mathrm{~g}$ for 10 $\min$ at $4{ }^{\circ} \mathrm{C}$. Aliquots of plasma were frozen in liquid nitrogen and stored at $-80{ }^{\circ} \mathrm{C}$. Saliva samples were collected at least $30 \mathrm{~min}$ after meal ingestion. To collect saliva, subjects lightly chewed on a cotton swab (Celluron, Hartmann, Germany) for enough time to saturate the cotton swab with saliva. The swab was then removed and depressed using a syringe to extract the saliva into a sample tube. After collection, saliva was frozen in liquid nitrogen and stored at $-80{ }^{\circ} \mathrm{C}$. Muscle biopsies were obtained from the middle region of the $\mathrm{M}$. vastus lateralis, $15 \mathrm{~cm}$ above the patella and approximately $4 \mathrm{~cm}$ below entry through the fascia, using the percutaneous needle biopsy technique (5). Muscle biopsy samples were dissected carefully and freed from any visible non-muscle material. The muscle samples were immediately frozen in liquid nitrogen and stored at $-80^{\circ} \mathrm{C}$ until further analysis.

\section{Resistance-type exercise sessions}

The resistance-type exercise sessions consisted of $45 \mathrm{~min}$ of moderate intensity lower-body resistance-type exercise. Subjects exercised with a single leg, which was randomized based on dominance (i.e., dominant vs non-dominant). Subjects first completed $10 \mathrm{~min}$ of unilateral cycling at $75 \mathrm{~W}$ with a cadence of 60-80 RPM. Afterwards, subjects performed 1 warm-up set at $50 \% 1 \mathrm{RM}$ followed by 4 sets of $8-10$ repetitions at $75 \% 1 \mathrm{RM}$ on the horizontal leg press machine (Technogym BV, Rotterdam, The Netherlands). After completing the leg press exercise, subjects performed 1 warm-up set at $50 \% 1 \mathrm{RM}$ followed by 4 sets of 8-10 repetitions at $75 \% 1 \mathrm{RM}$ on the leg extension machine (Technogym BV, Rotterdam, The Netherlands). Subjects were allowed to rest for 2 min between all sets.

\section{Body water deuterium enrichment}

Body water enrichment was analyzed using the saliva samples collected throughout the experimental protocol. All samples were centrifuged at 10,000 $\mathrm{g}$ to remove any debris. Following centrifugation, all samples were diluted 70 -fold with ddH2O in order to achieve deuterium enrichments within the detection limits of the GC-C-IRMS. After dilution, samples were prepared for analysis on a GC-C-IRMS using the protocol outlined by Scrimgeour et al. (47). Briefly, small plastic cups holding $4 \mathrm{mg}$ of catalyst (5\% platinum on alumina, 325 mesh, Sigma-Aldrich, St. Louis, USA) were placed inside $3 \mathrm{~mL}$ glass vials (Labco Exetainer, Labco limited, Lampeter, UK). $300 \mu \mathrm{L}$ of diluted saliva sample was then transferred into the vials. The glass vials were sealed using rubber septums and a screw cap. Air in each vial was simultaneously evacuated and replaced by hydrogen gas. The prepared vials were left at 21 
${ }^{\circ} \mathrm{C}$ for $24 \mathrm{~h}$ for deuterium equilibration to occur between the hydrogen gas and the saliva samples. The deuterium enrichment of the hydrogen gas was then measured in duplicate on a GC-C-IRMS (Micromass Optima IRMS fitted with a Multiprep and Gilson autoinjector, Micromass UK Limited, Manchester, UK). Standard regression curves were applied from a series of known standard enrichment values against the measured values to assess the linearity of the mass spectrometer and to account for deuterium loss during equilibration.

Plasma free $\left[{ }^{2} \mathrm{H}\right]$-alanine enrichment

Plasma amino acid enrichments were determined by gas chromatography-mass spectrometry analysis (GC-MS; Agilent 5975C MSD \& 7890A GC, Wilmington, Delaware, USA). Plasma samples were deproteinized with dry 5-sulfosalicylic acid. Free amino acids were purified using cation exchange chromatography (AG 50W-X8 resin, mesh size: 100$200 \mu \mathrm{m}$, ionic form: hydrogen; Bio-Rad Laboratories, Hercules, CA). The purified amino acids were converted into tert-butyldimethylsilyl (tert-BDMS) derivatives with MTBSTFA before analysis by GC-MS. The plasma free alanine mass isotopomers $(M, M+1)$ were determined using selective ion monitoring at $\mathrm{m} / \mathrm{z} 232$ and 233. Standard regression curves were applied from a series of known standard enrichment values against the measured values to assess the linearity of the mass spectrometer and to account for any isotope fractionation.

Intramuscular free and bound $\left[{ }^{2} \mathrm{H}\right]$-alanine enrichment

For measurement of $\left[{ }^{2} \mathrm{H}\right]$-alanine enrichment in the intramuscular free and mixed muscle protein pools, $55 \mathrm{mg}$ wet muscle was freeze dried. Collagen, blood, and other non-muscle fiber material were removed from the muscle fibers under a light microscope. The isolated muscle fiber mass (2-3 mg) was weighed and 7 volumes (7 times dry weight of isolated muscle fibers wet:dry ratio) of ice-cold $2 \%$ perchloric acid were added. The tissue was then sonicated and centrifuged. The supernatant was collected and processed in the same manner as the plasma samples, such that intracellular free $\left[{ }^{2} \mathrm{H}\right]$-alanine enrichments could be measured by using their t-butyldimethylsilyl derivatives on a gas chromatography-mass spectrometer. The protein pellet was washed with 3 additional $1.5 \mathrm{~mL}$ washes of $2 \%$ perchloric acid, dried, and hydrolyzed in $6 \mathrm{M} \mathrm{HCl}$ at $120{ }^{\circ} \mathrm{C}$ for 15-18 h. The hydrolyzed protein fraction was dried under a nitrogen stream while being heated at $120{ }^{\circ} \mathrm{C}$. After dissolving with a $50 \%$ acetic acid solution, samples were passed over Dowex exchange resin (AG 50W-X8, 100-200 mesh hydrogen form; Biorad, Hercules, CA, USA) by using 2 M $\mathrm{NH}_{4} \mathrm{OH}$. Thereafter, the eluate was dried, and the purified amino acids were derivatized to their $\mathrm{N}(\mathrm{O}, \mathrm{S})$-ethoxycarbonyl ethyl esters (26). The derivatized samples were measured using a gas chromatography-isotope ratio mass spectrometer (Thermo Fisher Scientific, MAT 253; Bremen, Germany) equipped with a pyrolysis oven using a $60 \mathrm{~m}$ DB-17MS column and $5 \mathrm{~m}$ precolumn (no. 122-4762; Agilent, Wilmington, DE, USA) and GC-Isolink. Ion masses 2 and 3 were monitored to determine the ${ }^{2} \mathrm{H} /{ }^{1} \mathrm{H}$ ratios of muscle protein bound alanine. A series 
of known standards were applied to assess linearity of the mass spectrometer and to control for the loss of tracer.

\section{Western blotting}

Muscle was homogenized as previously described (52). After protein quantification, equal amounts $(50 \mu \mathrm{g}$ protein per lane) of protein were loaded and standard SDS-PAGE procedures were followed. Antibodies included total and phosphorylated mTOR (Ser $\left.{ }^{2448}\right), \mathrm{S} 6$ protein kinase 1 (S6K1; $\left.\mathrm{Thr}^{339}\right)$, RS6 $\left(\mathrm{Ser}^{235} / \mathrm{Ser}^{236}\right)$, anti-phospho-eukaryotic translation initiation factor 4E-binding protein-1 (4E-BP1; Thr ${ }^{37 / 46}$ ), anti-mTOR, anti-S6K1, anti-ribosomal protein S6 (RS6), and anti-4E-BP1], which were purchased from Cell Signaling Technology (Danvers, MA, USA). $\alpha$-tubulin (Abcam) was used as a loading control. All samples for a given protein were detected on the same membrane using chemiluminescence and the FluorChem HD imaging system (Alpha Innotech, Santa Clara, CA, USA).

\section{Calculations}

Mixed muscle protein fractional synthetic rate (FSR) was determined using the incorporation of $\left[{ }^{2} \mathrm{H}\right]$-alanine into muscle proteins and either mean intracellular free $\left[{ }^{2} \mathrm{H}\right]$-alanine enrichment in each leg, mean free $\left[{ }^{2} \mathrm{H}\right]$-alanine enrichment in plasma or mean body water deuterium enrichment corrected by a factor of 3.7 based upon the deuterium labelling during de novo alanine synthesis. FSR was calculated using the standard precursor-product method:

$$
\operatorname{FSR}\left(\% \cdot \text { day }^{-1}\right)=\left(\frac{E_{m 2}-E_{m 1}}{E_{\text {precursor }} \times t}\right) \times 100
$$

$E_{m 1}$ and $E_{m 2}$ are the mixed muscle protein-bound enrichments on days 4 and day 7 , respectively. $E_{\text {precursor }}$ represents either mean intracellular free $\left[{ }^{2} \mathrm{H}\right]$-alanine enrichment in each leg, mean free $\left[{ }^{2} \mathrm{H}\right]$-alanine enrichment in plasma or body water deuterium enrichment corrected by a factor of 3.7 based upon the deuterium labelling of alanine during de novo synthesis. $t$ represents the time between biopsies on day 4 and day 7 .

\section{Statistics}

All data are expressed as mean + SEM. A one-factor repeated measures ANOVA with time as within-subjects factor was performed for the analysis of body water and plasma enrichments over time. A two-factor repeated measures ANOVA (time $x$ treatment) with time and treatment group (exercise vs control leg) as within-subjects factor was performed for the analysis of intramuscular free $\left[{ }^{2} \mathrm{H}\right]$-alanine and mixed muscle protein bound $\left[{ }^{2} \mathrm{H}\right]$-alanine enrichments. Upon identification of a significant time $x$ treatment interaction, Tukey post hoc testing was used to identify differences. FSR values were compared between treatments 


\section{Chapter 7}

using Student's paired t-tests. Pearson's $r$ product moment correlations were performed to examine the linear relationship between precursor pool enrichments, intramuscular free $\left[{ }^{2} \mathrm{H}\right]-$ alanine enrichment between treatments and FSR values calculated with different precursor pools. Statistical significance was set at $P<0.05$. All calculations were performed using SPSS 21.0 (Chicago, IL, USA). 


\section{Results}

Physical activity and diet

Subjects' baseline characteristics are presented in Table 7.1. During the 3-day resistancetype exercise training protocol, subjects consumed on average $11.2 \pm 0.4 \mathrm{MJ}$, with $43 \pm 3$ energy\% (En\%) as carbohydrate, $30 \pm 2 \mathrm{En} \%$ as fat, and $24 \pm 3 \mathrm{En} \%$ as protein. Dietary protein intake averaged $1.7 \pm 0.2 \mathrm{~g} \mathrm{~kg}^{-1}$ bodyweight per day. In addition, subjects ingested $30 \mathrm{~g}$ whey protein immediately after each exercise bout. During the 3-day resistance-type exercise protocol, subjects averaged $7266 \pm 686$ steps per day.

\section{Precursor pools}

Body water deuterium enrichment (Figure 7.2A) reached $0.62 \pm 0.02 \%$ on day 3 , which represented the start of the maintenance dosing period. Body water enrichments remained in steady state over the duration of the experiment $(P>0.05)$, and averaged $0.70 \pm 0.03 \%$ during the 3-day resistance-type exercise training protocol (days 4-7), when muscle protein synthesis rates were assessed. Plasma free $\left[{ }^{2} \mathrm{H}\right]$-alanine enrichment (Figure $7.2 \mathrm{C}$ ) reached $2.35 \pm 0.08 \mathrm{MPE}$ on day 3 of the experiment. Plasma free $\left[{ }^{2} \mathrm{H}\right]$-alanine remained in steady state over the duration of the experiment $(P>0.05)$, and averaged $2.57 \pm 0.11 \mathrm{MPE}$ during the assessment of muscle protein synthesis rates. Intracellular free $\left[{ }^{2} \mathrm{H}\right]$-alanine enrichments (Figure 7.3A) averaged 1.84 $\pm 0.06 \mathrm{MPE}$ on day 4 and increased to $2.15 \pm 0.08 \mathrm{MPE}$ on day 7 (time effect: $P<0.05$ ), with no differences detected between legs at each time point (time $x$ treatment: $P>0.05$ ). 

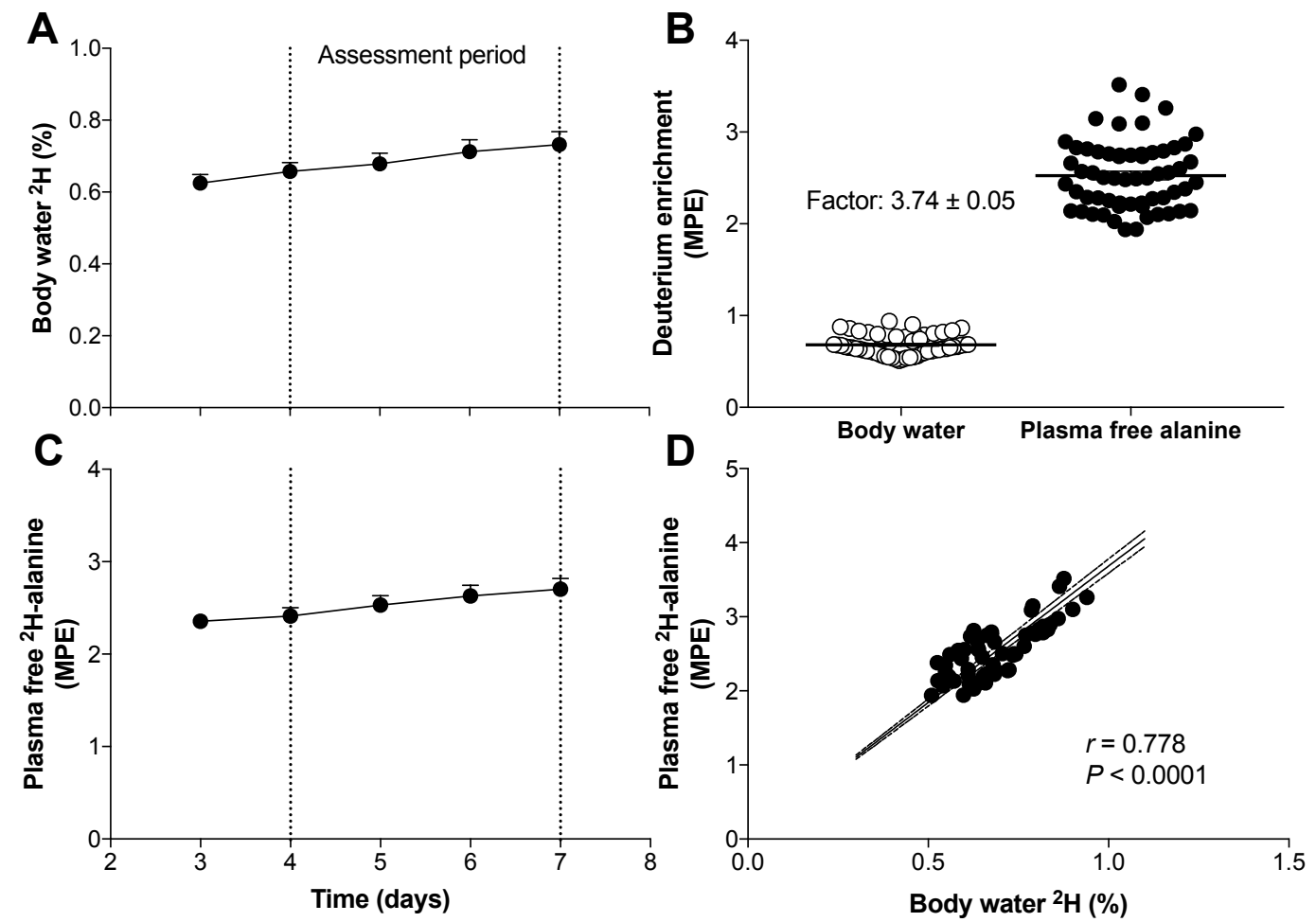

Figure 7.2 Body water deuterium enrichment $(A, \%)$ and plasma free $\left[{ }^{2} H\right]$-alanine enrichment $(B, M P E)$ displayed over time during oral deuterated water dosing in young males $(n=12)$. Dosing began on day 2 , subjects were in steady state between days 3 and 7. Values represent means + SEM. Data were analyzed using a one-way repeated measures ANOVA. Body water deuterium and plasma free [ $\left.{ }^{2} \mathrm{H}\right]$-alanine enrichment in corresponding samples expressed in relation to one another $(C, \%$ for body water deuterium, MPE for plasma free $\left[{ }^{2} \mathrm{H}\right]$-alanine). Correlation between body water deuterium enrichment and plasma free $\left[{ }^{2} \mathrm{H}\right]$-alanine enrichment of corresponding samples ( $D, \%$ for body water deuterium, MPE for plasma free [ $\left.{ }^{2} H\right]$-alanine). The solid line indicates the linear regression line of best fit, the dashed lines represent the $95 \%$ confidence interval. A significant positive correlation was observed $(P<0.0001)$.

\section{Endogenous deuterium labeling dynamics}

Plasma free $\left[{ }^{2} \mathrm{H}\right]$-alanine enrichment was 3.74 -fold greater when compared to body water deuterium enrichment (Figure 7.2B). Pearson's $r$ product moment correlations were performed between body water deuterium enrichments, plasma free $\left[{ }^{2} \mathrm{H}\right]$-alanine enrichments and intramuscular free $\left[{ }^{2} \mathrm{H}\right]$-alanine enrichments collected at the same time point. A significant positive $(r=0.778 ; P<0.0001)$ correlation was detected between body water deuterium and plasma free $\left[{ }^{2} \mathrm{H}\right]$-alanine enrichments (Figure 7.2D). A significant positive $(r=0.919 ; P<0.001)$ correlation was detected between body water deuterium and intramuscular free $\left[{ }^{2} \mathrm{H}\right]$-alanine enrichments (day 4 and day 7 ) in the control leg (Figure 7.3B). A significant positive $(r=0.845 ; P<0.001)$ correlation was detected between body water deuterium and intramuscular free $\left[{ }^{2} \mathrm{H}\right]$-alanine enrichments (day 7 ) in the exercised leg (Figure 7.3C). A significant positive $(r=0.808 ; P<0.0001)$ correlation was detected between plasma free $\left[{ }^{2} \mathrm{H}\right]$-alanine and intramuscular free $\left[{ }^{2} \mathrm{H}\right]$-alanine enrichments (day 4 and day 7 ) in 
the non-exercised, control leg (Figure 7.3D). A significant positive $(r=0.820 ; P<0.001)$ correlation was detected between plasma free $\left[{ }^{2} \mathrm{H}\right]$-alanine and intramuscular free $\left[{ }^{2} \mathrm{H}\right]$ alanine enrichments (day 7) in the exercised leg (Figure 7.3E). A significant positive ( $r=$ 0.905; $P<0.0001)$ correlation was detected between intramuscular free $\left[{ }^{2} \mathrm{H}\right]$-alanine enrichments in the exercised and non-exercised control leg (day 7) (Figure 7.3F). 

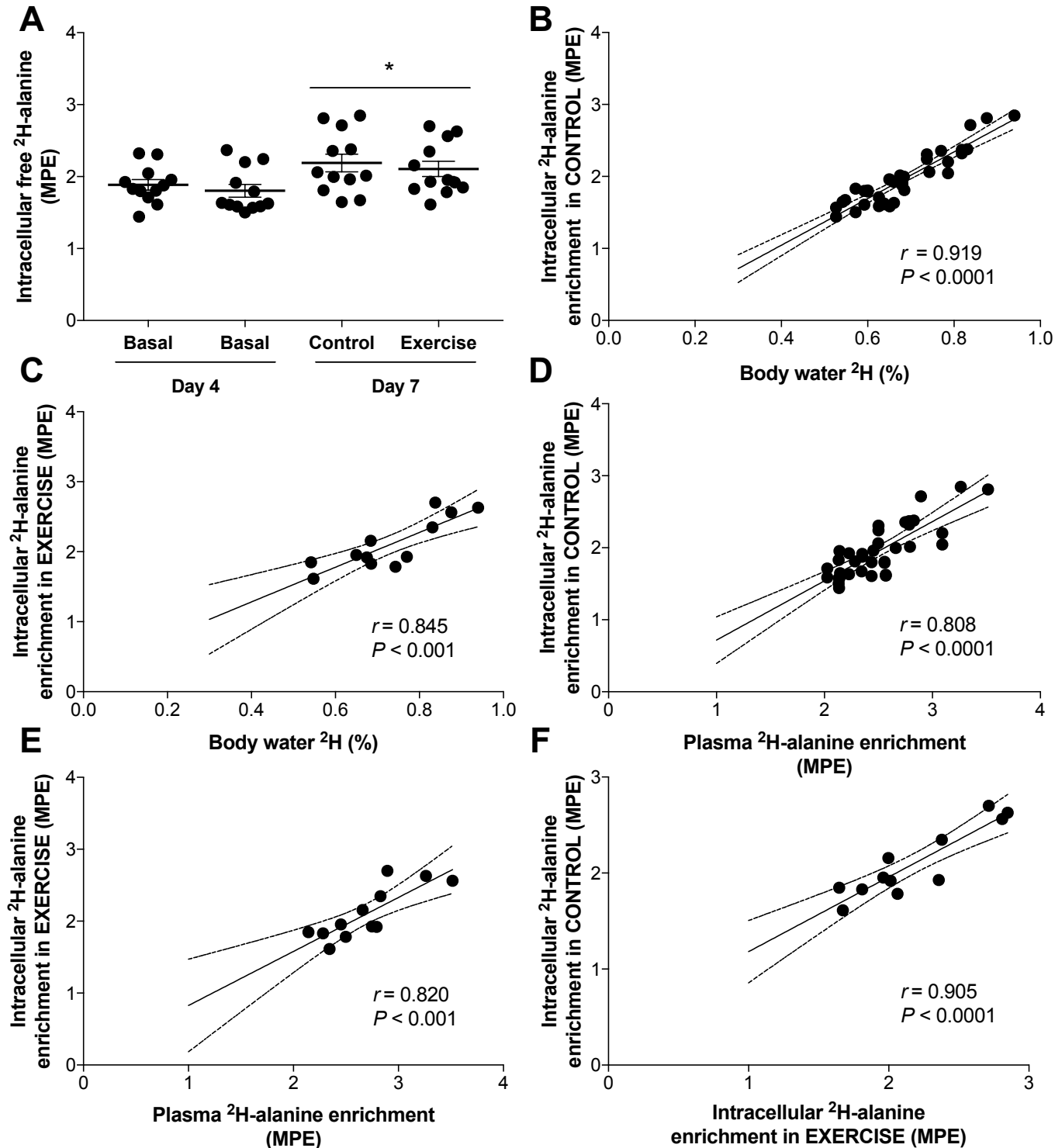

Figure 7.3 Intramuscular free $\left[{ }^{2} \mathrm{H}\right]$-alanine enrichment (A, MPE) from the vastus lateralis muscle of each leg at day 4 (Basal) and day 7 (Control and Exercise). Data were analyzed using a two-way repeated measures ANOVA with time and treatment leg as within subject factors. *Significantly different compared with basal $(P<0.01)$. Multiple correlation analyses were conducted between precursor pools. Panel B: Intramuscular free [ $\left.{ }^{2} \mathrm{H}\right]$-alanine enrichment in control leg (MPE) was positively correlated with body water deuterium enrichment $(\% ; P<0.001)$. Panel C: Intramuscular free $\left[{ }^{2} \mathrm{H}\right]$-alanine enrichment in exercise leg (MPE) was positively correlated with body water deuterium enrichment (\%; $P<0.001)$. Panel D: Intramuscular free $\left[{ }^{2} \mathrm{H}\right]$-alanine enrichment in control leg (MPE) was positively correlated with plasma free $\left[{ }^{2} \mathrm{H}\right]$-alanine enrichment (MPE; $P<0.001$ ). Panel $E$ : Intramuscular free $\left[{ }^{2} \mathrm{H}\right]$-alanine enrichment in exercise leg (MPE) was positively correlated with plasma free $\left[{ }^{2} \mathrm{H}\right]-$ alanine enrichment (MPE; $\mathrm{P}<0.001)$. Panel $\mathrm{F}$ : Intramuscular free $\left[{ }^{2} \mathrm{H}\right]$-alanine enrichment in control leg (MPE) was positively correlated with intramuscular free $\left[{ }^{2} \mathrm{H}\right]$-alanine enrichment in exercise leg $(\mathrm{MPE} ; \mathrm{P}<0.001)$. The solid line indicates the linear regression line of best fit, the dashed lines represent the $95 \%$ confidence interval. 


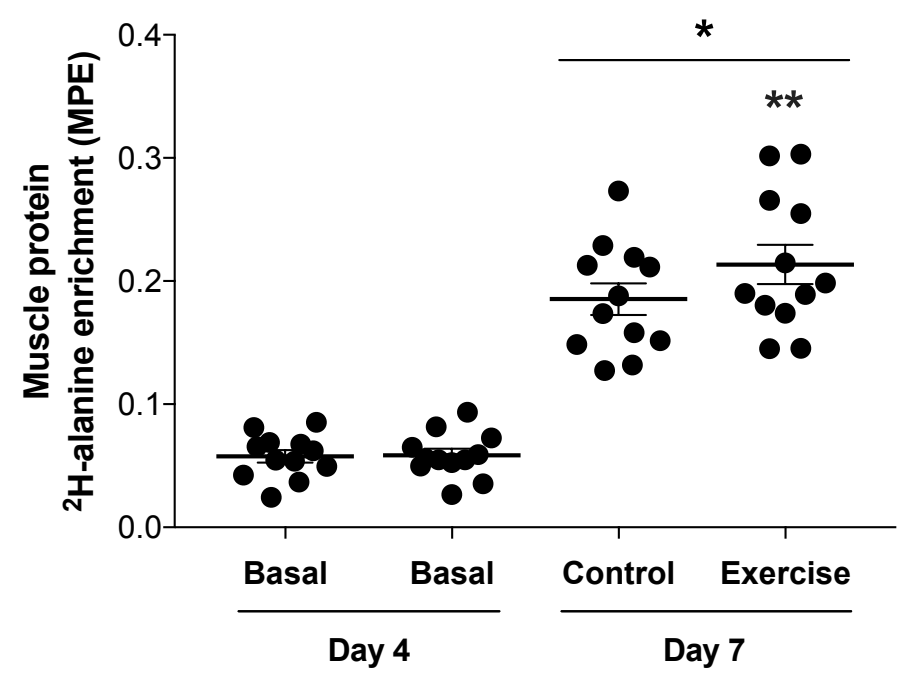

Figure 7.4 Muscle protein bound [ ${ }^{\mathrm{H}} \mathrm{H}$-alanine enrichment (MPE) from the vastus lateralis muscle of each leg at day 4 (Basal) and day 7 (Control and Exercise). The control leg completed normal activities of daily living and the exercise leg completed unilateral resistance-type exercise (leg press and leg extension) once per day for 3 days. Data were analyzed using a two-way repeated measures ANOVA with time and treatment leg as within subject factors. *Significantly different compared with basal $(P<0.05)$. ${ }^{*}$ Significantly different compared with control $(P<0.05)$.

\section{Muscle protein synthesis rates}

Muscle protein-bound $\left[{ }^{2} \mathrm{H}\right]$-alanine enrichments were measured in muscle samples collected on day 4 and day 7 of the experimental protocol in the exercised and non-exercised control leg. Muscle protein bound $\left[{ }^{2} \mathrm{H}\right]$-alanine enrichments (Figure 7.4) averaged $0.0577 \pm 0.0051$ MPE in the non-exercised control leg and $0.0585 \pm 0.0053$ MPE in the exercised leg on day 4 with no differences between legs $(P>0.05)$. Muscle protein bound $\left[{ }^{2} \mathrm{H}\right]$-alanine enrichments increased over time in both groups and averaged $0.185 \pm 0.013 \mathrm{MPE}$ in the non-exercised control leg and $0.214 \pm 0.016$ MPE in the exercised leg on day $7(P<0.05$ for differences between legs). Muscle protein FSR (in $\% \cdot d^{-1}$ ) was calculated using mean body water deuterium enrichment corrected by a factor of 3.7 as precursor (Figures 7.5A and 7.5D), mean plasma free $\left[{ }^{2} \mathrm{H}\right]$-alanine enrichments as precursor (Figure 7.5B and 7.5E) and mean intramuscular free $\left[{ }^{2} \mathrm{H}\right]$-alanine enrichments as precursor (Figures $7.5 \mathrm{C}$ and $\mathbf{7 . 5 F}$ ). When calculated based upon body water deuterium enrichments as a precursor, muscle protein synthesis rates were $24 \pm 8 \%$ higher in the leg that performed resistance-type exercise $\left(1.984 \pm 0.118 \% \cdot d^{-1}\right)$ when compared to the non-exercised control leg condition $(1.642 \pm$ $\left.0.089 \% \cdot d^{-1} ; P<0.05\right)$. When calculated based upon plasma free $\left[{ }^{2} \mathrm{H}\right]$-alanine enrichments as a precursor, muscle protein synthesis rates were higher $(24 \pm 8 \%)$ in the exercised leg $(1.975$ $\left.\pm 0.108 \% \cdot d^{-1}\right)$ when compared to the control leg $\left(1.637 \pm 0.085 \% \cdot d^{-1} ; P<0.05\right)$. When calculated based upon intramuscular free $\left[{ }^{2} \mathrm{H}\right]$-alanine enrichments as a precursor, mixed muscle protein synthesis rates were $29 \pm 8 \%$ higher in the exercise leg $(2.609 \pm 0.150 \% \cdot d$ $\left.{ }^{1}\right)$ when compared to the control leg $\left(2.071 \pm 0.108 \% \cdot d^{-1} ; P<0.01\right)$. A Pearson's $r$ product moment correlation was performed between FSR calculated with body water deuterium 


\section{Chapter 7}

enrichment as precursor and FSR calculated with intramuscular free $\left[{ }^{2} \mathrm{H}\right]$-alanine enrichment as precursor for both legs (Figure 7.6). A significant positive $(r=0.967 ; P<0.0001)$ correlation was detected.
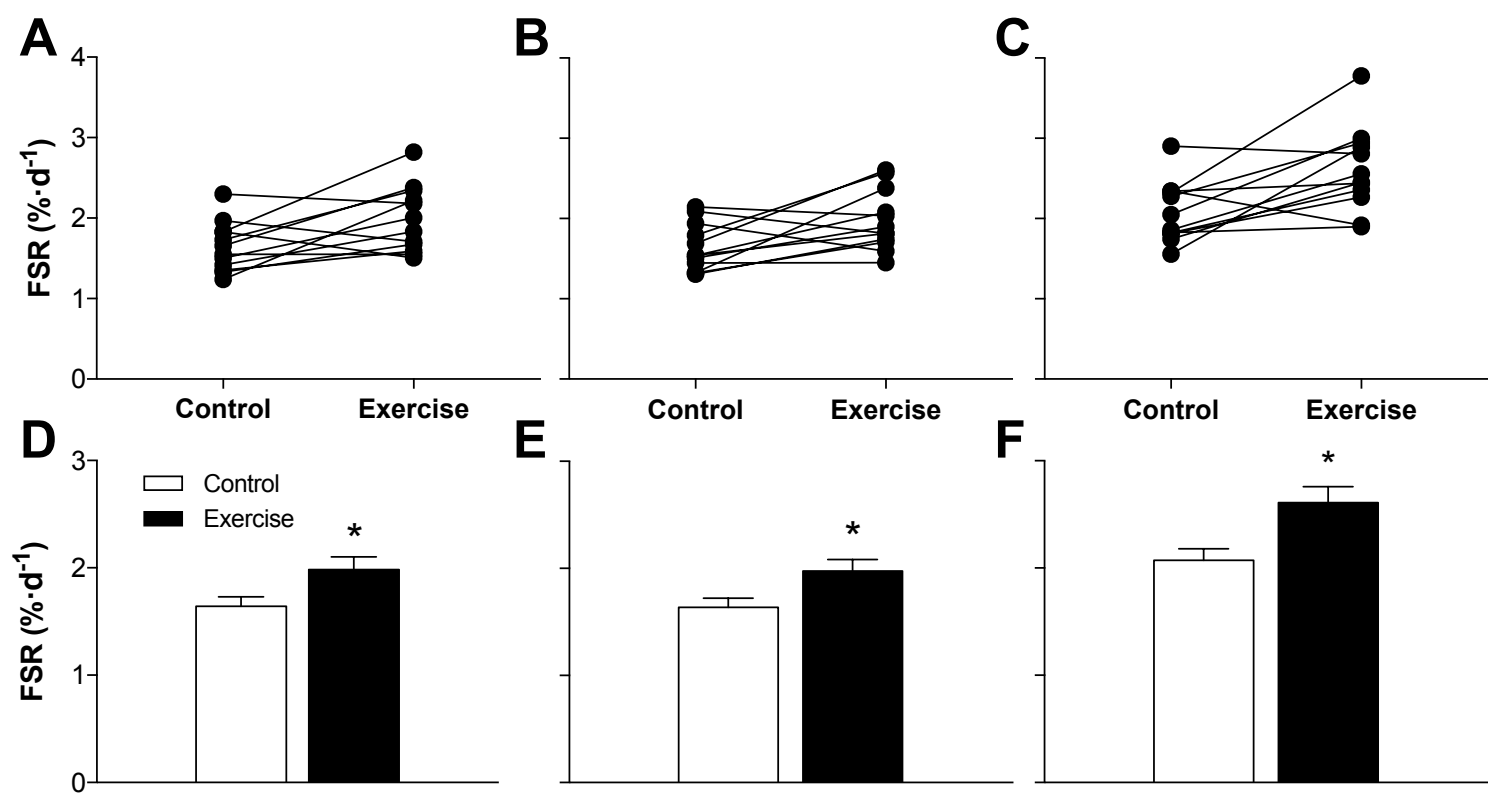

Figure 7.5 Mixed muscle protein fractional synthetic rates (FSR in $\% \cdot h^{-1}$ ) assessed in young males while performing bouts of unilateral resistance-type exercise on 3 consecutive days using deuterated water dosing. Fractional synthetic rates were calculated using body water deuterium (panels $\mathrm{A}$ and D), plasma free [ $\left.{ }^{2} \mathrm{H}\right]$-alanine (panels $B$ and $E$ ), intramuscular free $\left[{ }^{2} H\right]$-alanine enrichment (panels $C$ and $F$ ) as precursor. Individual values represented in panels $A, B$ and $C$. Values in panels $D, E$ and $F$ are represented as means + SEM. Data were analyzed with student's unpaired t-test. ${ }^{\star}$ Significantly different compared to control leg $(P<0.05)$.

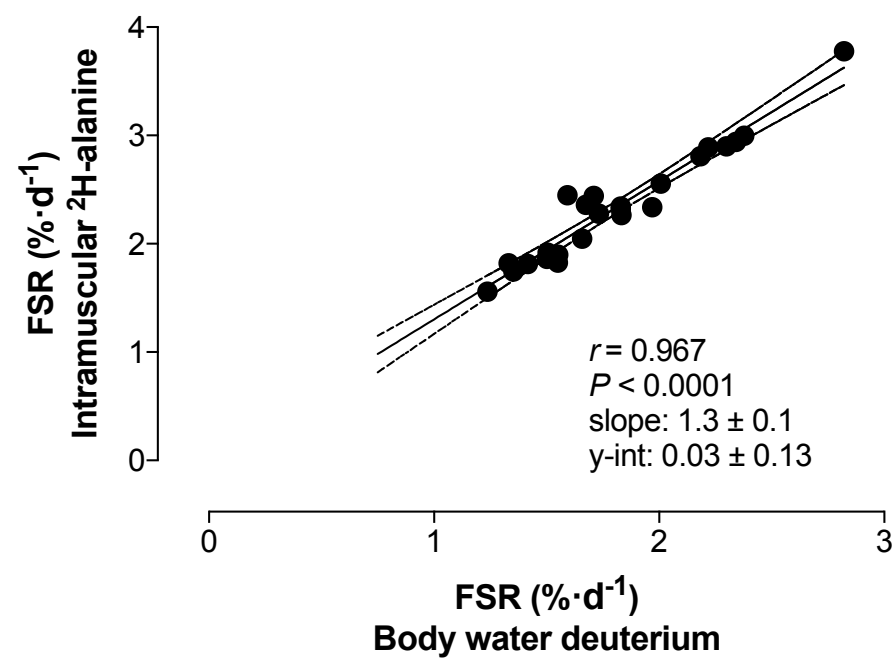

Figure 7.6 Pearson's $r$ product moment correlation performed between mixed muscle protein fractional synthetic rates (FSR in \% $\cdot h^{-1}$ ) calculated with body water deuterium enrichment as precursor and intramuscular free $\left[{ }^{2} \mathrm{H}\right]$-alanine enrichment as precursor. The solid line indicates the linear regression line of best fit, and the dashed lines represent the $95 \%$ confidence interval. A significant positive correlation was detected $(P<$ 0.0001). 


\section{Cell signaling analyses}

The phosphorylation status (ratio of phosphorylated to total protein) of key proteins involved in the initiation of muscle protein synthesis are presented in Figure 7.7. No significant differences were detected in muscle tissue samples collected $24 \mathrm{~h}$ after the last exercise session from the exercised and non-exercised control leg.
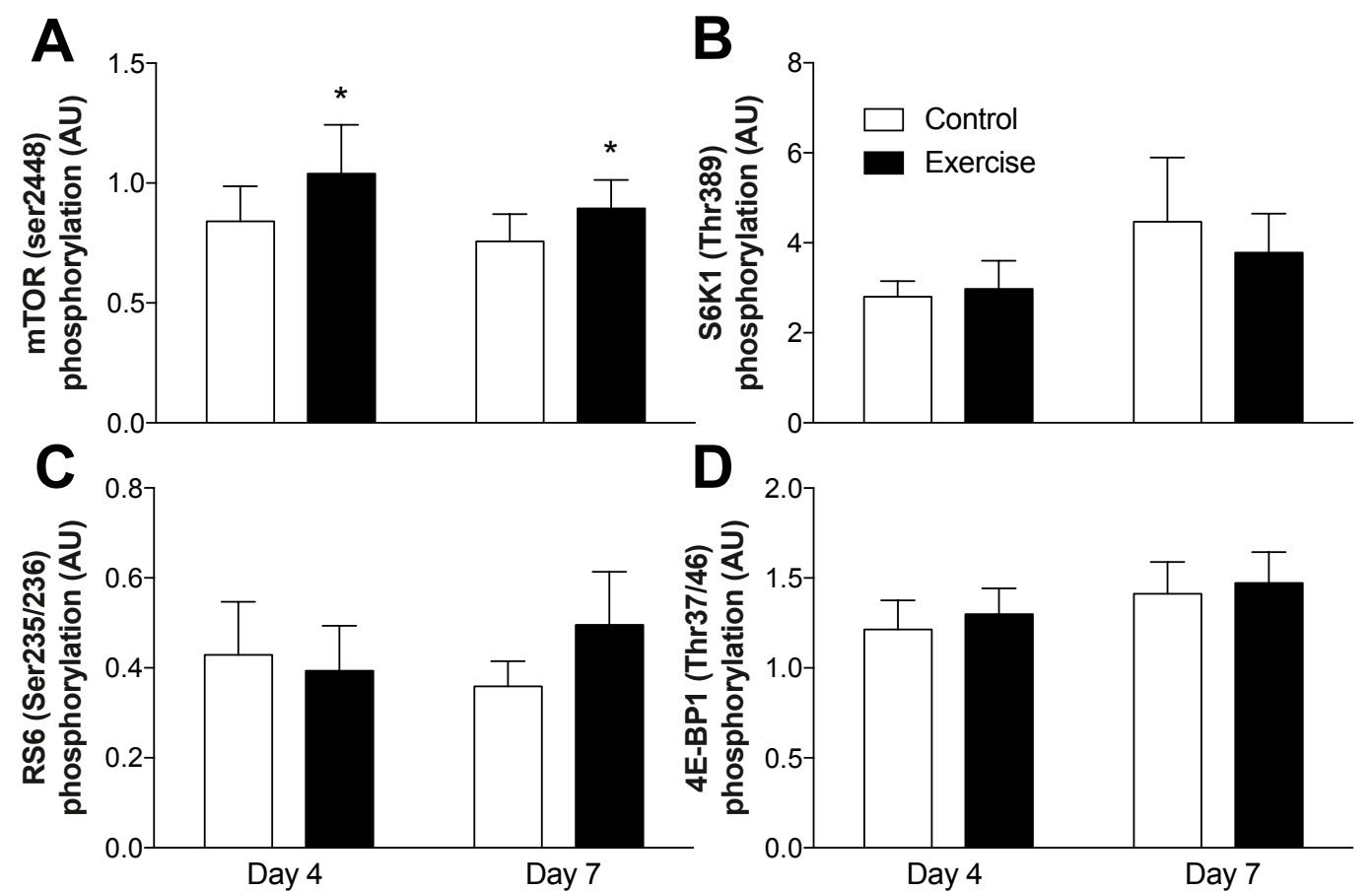

Figure 7.7 Muscle phosphorylation status (ratio of phosphorylated to total protein) of mammalian target of rapamycin (mTOR; A), S6 protein kinase 1 (S6K; B), ribosomal protein S6 (RS6; C), and eukaryotic translation initiation factor 4E-binding protein-1 (4E-BP1; D) in young males $(n=12)$ immediately before (day 4$)$ and $24 \mathrm{~h}$ after completing the last unilateral exercise bout from the exercised and non-exercise control leg (day 7). Values represent means + SEM. Data were analyzed with a two-way repeated measures (time $x$ treatment leg) ANOVA. $A$; time effect: $P>0.05$, treatment leg effect: $P<0.05$, time $x$ treatment group: $P>0.05$. $B$; time effect: $P>$ 0.05 , treatment effect: $P>0.05$, time $x$ treatment group: $P>0.05$. $C$; time effect: $P>0.05$, treatment effect: $P$ $>0.05$, time $x$ treatment group: $P>0.05$. D; time effect: $P>0.01$, treatment effect: $P>0.01$, time $x$ treatment group: $P>0.05 *$ Significantly different compared to control leg $(P<0.05)$. 


\section{Discussion}

In the present study, we applied deuterated water to assess the impact of resistance-type exercise on muscle protein synthesis rates over multiple days in free-living conditions. Unilateral resistance-type exercise completed on 3 consecutive days resulted in $~ 25 \%$ higher muscle protein synthesis rates in the exercised leg when compared to the contralateral, non-exercised control leg.

Previous studies have applied intravenous stable isotope labelled amino acid infusions to assess skeletal muscle protein synthesis rates during the acute post-exercise recovery phase $(2,10,11,14,38,39,58,59)$. However, the post-exercise recovery phase extends past the traditional 6-12 $\mathrm{h}$ tracer infusion assessment period, and may be influenced by diurnal factors such as diet (1), hormonal responses (56) and sleep (24,25). Currently, few studies have assessed the overall skeletal muscle protein synthetic response to resistance-type exercise performed under free-living conditions over multiple days $(4,8,16,57)$. Here, we applied deuterated water to assess the muscle protein synthetic response to resistance-type exercise performed daily over a 3-day assessment period. Our deuterated water dosing protocol increased body water deuterium enrichment to $0.62 \pm 0.02 \%$ and $\left[{ }^{2} \mathrm{H}\right]$-alanine enrichment to $2.35 \pm 0.08 \mathrm{MPE}$ after the first dosing day (day 3 ). The body water and plasma enrichments remained in steady state for the remainder of the 3-day assessment period (Figures 7.2A and 7.2C). The labelling coefficient between body water deuterium and plasma free $\left[{ }^{2} \mathrm{H}\right]-$ alanine enrichment was $3.74 \pm 0.05$ (Figure 7.2B). This labelling coefficient is directly in line with previous work $(19,40,57)$, and reflects the rapid and tightly controlled equilibrium between body water deuterium and the free alanine precursor pool(s). As such, our dosing protocol resulted in deuterium precursor conditions that allowed us to quantify fractional muscle protein synthesis rates by measuring the increase in $\left[{ }^{2} \mathrm{H}\right]$-alanine incorporation over the 3-day period in the exercised and non-exercised leg muscle tissue.

In the present study, we applied a unilateral leg exercise design and took muscle biopsies to allow direct assessment of the surplus effect of (local) resistance-type exercise on muscle protein synthesis rates under free-living conditions. We found that muscle protein synthesis rates averaged $1.642 \pm 0.089 \% \cdot d^{-1}$ (or $0.068 \pm 0.004 \% \cdot h^{-1}$; Figure 7.5D) in the nonexercised, control leg and $1.984 \pm 0.118 \% \cdot \mathrm{d}^{-1}\left(0.083 \pm 0.005 \% \cdot \mathrm{h}^{-1}\right.$; Figure $\left.7.5 \mathrm{D}\right)$ in the resistance-type exercised leg. These daily muscle protein synthesis rates agree well with the more acute stable isotope infusion studies, as basal, post-absorptive muscle protein synthesis rates typically range between $0.02-0.04 \% \cdot h^{-1}(11,12,22,35)$ and acute postexercise muscle protein synthesis rates have been shown to range between $0.06-0.10 \% \cdot h^{-1}$ $(11,15,28,38,41,42,58,59)$. Despite the relatively high habitual physical activity level and high protein intake of our young male subjects, our data demonstrate $24 \pm 8 \%$ higher muscle protein synthesis rates in the leg that performed $45 \mathrm{~min}$ of resistance-type exercise daily when compared to the non-exercised, control leg $(P<0.05)$. These findings align well with recent work from Wilkinson et al., who applied a deuterated water approach and showed 
that unilateral resistance-type exercise results in $33 \%$ higher muscle protein synthesis rates over a 4-day period when compared to the contralateral, non-exercised control leg (57). We extend on their findings by showing $24 \%$ higher muscle protein synthesis rates in the exercised compared with the control leg despite the application of a different deuterated water dosing strategy, a different exercise protocol, and measuring mixed muscle as opposed to myofibrillar protein synthesis rates.

Recent work by Mitchell et al. has demonstrated that muscle protein synthesis rates assessed during acute post-exercise recovery are not predictive of absolute changes in muscle mass observed during more prolonged resistance-type exercise training (34). This finding has garnered attention in the field as the interpretation of acute measures of post-exercise muscle protein synthesis rates may be difficult to align with long-term changes in skeletal muscle mass $(3,32,33)$. However, it is not surprising that assessment of muscle protein synthesis in the acute post-exercise recovery phase under controlled laboratory settings are not predictive of long-term changes in muscle mass. For instance, it has been well described that resistance-type exercise increases post-prandial muscle protein synthesis rates by as much as $50-100 \%$ during the early stages of post-exercise recovery $(11,38,39,59)$. In comparison, the present data also demonstrate a stimulation in muscle protein synthesis in the exercised versus non-exercised leg when assessed over a 3-day period, albeit to a far lower extent (24\% higher). Our observation of a lower relative stimulation in muscle protein synthesis rates when assessed over an extended period of time likely reflects the incorporation of other anabolic factors into the assessment, such as dietary protein intake, habitual physical activity, sleep, hormonal fluctuations and transient anabolic signalling responses. Considering that the interaction of these anabolic factors contributes to longterm changes in skeletal muscle mass, our findings likely demonstrate that the application of the deuterated water method provides a more accurate tool when attempting to align shorter-term muscle protein synthetic responses with changes in skeletal muscle mass observed over a long-term intervention (16). However, future work is still warranted to confirm whether muscle protein synthesis rates assessed over multiple days is more predictive of subsequent net changes in muscle mass during various long-term interventions. Resistance-type exercise has been well-reported to phosphorylate intramuscular signaling proteins that regulate protein translation-initiation, with mTOR and its downstream targets, S6 kinase, RS6 and 4E-BP1 being of particular relevance. Here, we observed no differences in the phosphorylation status of these proteins between the exercised and non-exercised control leg $24 \mathrm{~h}$ following the last exercise session. Though our biopsy timing does not allow us to assess transient changes in the phosphorylation status of these proteins during recovery from exercise, our findings support an increasing number of studies that demonstrate the inability to align translation initiation factors with the physiological outcome of muscle protein synthesis rates $(13,23,55,59)$.

The choice of precursor pool is an important consideration when assessing muscle protein synthesis rates $(9,48)$. Although it would be ideal to use the true precursor (aminoacyl-tRNA 
enrichment) for assessing muscle protein synthesis rates, accurate analysis is technically difficult to perform and would require tissue sample sizes too large to collect (>1000 $\mathrm{mg}$ ) $(54,60)$. As such, researchers applying stable isotope amino acid infusion protocols generally use the plasma or intramuscular free amino acid pools as a surrogate for aminoacyl-tRNA enrichment (48). Prior work applying the deuterated water approach has suggested that body water deuterium enrichment, assessed in saliva or urine samples, can be used as a reliable surrogate precursor for calculating muscle protein synthesis rates $(30,40,57)$. However, few data exist on the reliability of using body water deuterium enrichment as a precursor as opposed to using intramuscular free $\left[{ }^{2} \mathrm{H}\right]$-alanine enrichment. In the present study, we calculated fractional synthetic rates based upon three different precursor pools (i.e., body water deuterium (Figure 7.5D), plasma free $\left[{ }^{2} \mathrm{H}\right]$-alanine (Figure 7.5E) and intramuscular free $\left[{ }^{2} \mathrm{H}\right]$-alanine (Figure 7.5F) enrichments). Across all calculations we found that resistance-type exercise resulted in 24-29\% higher muscle protein synthesis rates when compared to the non-exercised control leg, with no differences detected between the choice of precursor $(P>0.05)$. Furthermore, we found a strong positive correlation $(r=0.967$; $P<0.0001$ ) between muscle protein synthesis rates calculated using body water deuterium as a precursor and muscle protein synthesis rates calculated using intramuscular free $\left[{ }^{2} \mathrm{H}\right]-$ alanine as a precursor (Figure 7.6). These findings reinforce the prior suggestions that body water deuterium enrichment represents an appropriate precursor for calculating muscle protein fractional synthetic rates $(30,40,57)$. Saliva sampling provides a substantial advantage over repeated blood and/or muscle tissue sampling and reduces the burden on test subjects, adding to the benefits of using the deuterated water approach to study muscle protein synthesis rates in more prolonged, practical and real-life (exercise) settings.

The findings presented in this study further support the use of deuterated water dosing as a practical approach to assess changes in muscle protein synthesis rates during interventions performed over a period of several days to even weeks $(7,8,20,29,36,44,45,57)$. We consider the single dosing day and maintenance dosing period as an effective means to rapidly increase deuterium enrichment and maintain precursor steady-state for days-toweeks of an assessment period. Furthermore, the observation that body water deuterium rapidly equilibrates with free $\left[{ }^{2} \mathrm{H}\right]$-alanine precursor pools permits the reliable assessment of muscle protein synthesis rates by collecting muscle biopsies and saliva samples. As such, the deuterated water method provides a practical approach to study test participants in a nonlaboratory, free-living setting. This approach will serve to provide novel insight into current gaps in our understanding into the dynamic nature of skeletal muscle reconditioning under different conditions.

In conclusion, daily resistance-type exercise increases local muscle protein synthesis rates by $\sim 25 \%$ when assessed over multiple days in vivo in humans. The application of deuterated water provides a practical approach to assess the muscle protein synthetic response to various interventional strategies performed over multiple days to weeks. 


\section{References}

1. Areta JL, Burke LM, Ross ML, Camera DM, West DWD, Broad EM, Jeacocke NA, Moore DR, Stellingwerff T, Phillips SM, Hawley JA, Coffey VG. Timing and distribution of protein ingestion during prolonged recovery from resistance exercise alters myofibrillar protein synthesis. J Physiol 591: 23192331, 2013.

2. Atherton PJ, Kumar V, Selby AL, Rankin D, Hildebrandt W, Phillips BE, Williams JP, Hiscock N, Smith $\mathrm{K}$. Enriching a protein drink with leucine augments muscle protein synthesis after resistance exercise in young and older men. Clin Nutr 36: 888-895, 2017.

3. Atherton PJ, Miller BF, Burd NA, Macnaughton LS, Murton AJ, Camera DM, Pancheva AV, Wang X, Vagula MC, Phillips BE, Brook MS, Wilkinson DJ, Smith K, Etheridge TE, Hamilton KL, Beals JW, van Vliet S, van Loon LJC, Wardle SL, Tipton KD, Stephens FB, Billeter R, Wall BT, Hawley JA, Panchev VS, Pancheva MV. Commentaries on Viewpoint: What is the relationship between acute measure of muscle protein synthesis and changes in muscle mass? J Appl Physiol 118: 498-503, 2015.

4. Bell KE, Séguin C, Parise G, Baker SK, Phillips SM. Day-to-Day Changes in Muscle Protein Synthesis in Recovery From Resistance, Aerobic, and High-Intensity Interval Exercise in Older Men. J Gerontol A Biol Sci Med Sci 70: 1024-1029, 2015.

5. Bergström J, Hultman E. A study of the glycogen metabolism during exercise in man. Scand J Clin Lab Invest 19: 218-228, 1967.

6. Biolo G, Maggi SP, Williams BD, Tipton KD, Wolfe RR. Increased rates of muscle protein turnover and amino acid transport after resistance exercise in humans. Am J Physiol 268: E514-20, 1995.

7. Brook MS, Wilkinson DJ, Mitchell WK, Lund JN, Phillips BE, Szewczyk NJ, Greenhaff PL, Smith K, Atherton PJ. Synchronous deficits in cumulative muscle protein synthesis and ribosomal biogenesis underlie age-related anabolic resistance to exercise in humans. J Physio/ 594: 7399-7417, 2016.

8. Brook MS, Wilkinson DJ, Mitchell WK, Lund JN, Szewczyk NJ, Greenhaff PL, Smith K, Atherton PJ. Skeletal muscle hypertrophy adaptations predominate in the early stages of resistance exercise training, matching deuterium oxide-derived measures of muscle protein synthesis and mechanistic target of rapamycin complex 1 signaling. FASEB J 29: 4485-4496, 2015.

9. Burd NA, Cermak NM, Kouw IWK, Gorissen SH, Gijsen AP, van Loon LJC. The use of doubly labeled milk protein to measure postprandial muscle protein synthesis rates in vivo in humans. $J$ Appl Physiol 117: 1363-1370, 2014.

10. Burd NA, Gorissen SH, van Loon LJC. Anabolic resistance of muscle protein synthesis with aging. Exerc Sport Sci Rev 41: 169-173, 2013.

11. Burd NA, Gorissen SH, van Vliet S, Snijders T, van Loon LJ. Differences in postprandial protein handling after beef compared with milk ingestion during postexercise recovery: a randomized controlled trial. Am J Clin Nutr 102: 828-836, 2015.

12. Burd NA, Holwerda AM, Selby KC, West DWD, Staples AW, Cain NE, Cashaback JGA, Potvin JR, Baker SK, Phillips SM. Resistance exercise volume affects myofibrillar protein synthesis and anabolic signalling molecule phosphorylation in young men. J Physiol 588: 3119-3130, 2010.

13. Burd NA, West DWD, Moore DR, Atherton PJ, Staples AW, Prior T, Tang JE, Rennie MJ, Baker SK, Phillips SM. Enhanced amino acid sensitivity of myofibrillar protein synthesis persists for up to $24 \mathrm{~h}$ after resistance exercise in young men. J Nutr 141: 568-573, 2011.

14. Chesley A, MacDougall JD, Tarnopolsky MA, Atkinson SA, Smith K. Changes in human muscle protein synthesis after resistance exercise. J Appl Physiol 73: 1383-1388, 1992.

15. Churchward-Venne TA, Breen L, Di Donato DM, Hector AJ, Mitchell CJ, Moore DR, Stellingwerff T, Breuille D, Offord EA, Baker SK, Phillips SM. Leucine supplementation of a low-protein mixed macronutrient beverage enhances myofibrillar protein synthesis in young men: a double-blind, randomized trial. Am J Clin Nutr 99: 276-286, 2014.

16. Damas F, Phillips SM, Libardi CA, Vechin FC, Lixandrão ME, Jannig PR, Costa LAR, Bacurau AV, Snijders T, Parise G, Tricoli V, Roschel H, Ugrinowitsch C. Resistance training-induced changes in integrated myofibrillar protein synthesis are related to hypertrophy only after attenuation of muscle damage. J Physiol 594: 5209-5222, 2016.

17. Dreyer HC, Drummond MJ, Pennings B, Fujita S, Glynn EL, Chinkes DL, Dhanani S, Volpi E, Rasmussen BB. Leucine-enriched essential amino acid and carbohydrate ingestion following resistance exercise 
enhances mTOR signaling and protein synthesis in human muscle. Am J Physiol Endocrinol Metab 294: E392-400, 2008.

18. Drummond MJ, Rasmussen BB. Leucine-enriched nutrients and the regulation of mammalian target of rapamycin signalling and human skeletal muscle protein synthesis. Curr Opin Clin Nutr Metab Care 11: 222-226, 2008.

19. Dufner DA. Using $2 \mathrm{H} 2 \mathrm{O}$ to study the influence of feeding on protein synthesis: effect of isotope equilibration in vivo vs. in cell culture. Am J Physiol Endocrinol Metab 288: E1277-E1283, 2005.

20. Gasier HG, Fluckey JD, Previs SF, Wiggs MP, Riechman SE. Acute resistance exercise augments integrative myofibrillar protein synthesis. Metabolism 61: 153-156, 2012.

21. Gasier HG, Fluckey JD, Previs SF. The application of $2 \mathrm{H} 2 \mathrm{O}$ to measure skeletal muscle protein synthesis. Nutr Metab 7: 31-8, 2010.

22. Gorissen SHM, Burd NA, Hamer HM, Gijsen AP, Groen BB, van Loon LJC. Carbohydrate coingestion delays dietary protein digestion and absorption but does not modulate postprandial muscle protein accretion. J Clin Endocrinol Metab 99: 2250-2258, 2014.

23. Greenhaff PL, Karagounis LG, Peirce N, Simpson EJ, Hazell M, Layfield R, Wackerhage H, Smith K Atherton P, Selby A, Rennie MJ. Disassociation between the effects of amino acids and insulin on signaling, ubiquitin ligases, and protein turnover in human muscle. Am J Physiol Endocrinol Metab 295: E595-604, 2008.

24. Groen BBL, Res PT, Pennings B, Hertle E, Senden JMG, Saris WHM, van Loon LJC. Intragastric protein administration stimulates overnight muscle protein synthesis in elderly men. Am J Physiol Endocrinol Metab 302: E52-60, 2012.

25. Holwerda AM, Kouw IW, Trommelen J, Halson SL, Wodzig WK, Verdijk LB, van Loon LJ. Physical Activity Performed in the Evening Increases the Overnight Muscle Protein Synthetic Response to Presleep Protein Ingestion in Older Men. J Nutr 146: 1307-1314, 2016.

26. Hušek P. Amino acid derivatization and analysis in five minutes. FEBS Letters 280: 354-356, 1991.

27. Koopman R, van Loon LJC. Aging, exercise, and muscle protein metabolism. J Appl Physiol 106: 20402048, 2009.

28. Koopman R, Verdijk L, Manders RJF, Gijsen AP, Gorselink M, Pijpers E, Wagenmakers AJM, van Loon LJC. Co-ingestion of protein and leucine stimulates muscle protein synthesis rates to the same extent in young and elderly lean men. Am J Clin Nutr 84: 623-632, 2006.

29. MacDonald AJ, Johns N, Stephens N, Greig C, Ross JA, Small AC, Husi H, Fearon KCH, Preston T. Habitual Myofibrillar Protein Synthesis Is Normal in Patients with Upper GI Cancer Cachexia. Clin Cancer Res 21: 1734-1740, 2015.

30. MacDonald AJ, Small AC, Greig CA, Husi H, Ross JA, Stephens NA, Fearon KCH, Preston T. A novel oral tracer procedure for measurement of habitual myofibrillar protein synthesis. Rapid Commun Mass Spectrom 27: 1769-1777, 2013.

31. Mayhew JL, Prinster JL, Ware JS, Zimmer DL, Arabas JR, Bemben MG. Muscular endurance repetitions to predict bench press strength in men of different training levels. J Sports Med Phys Fitness 35: 108113, 1995.

32. Mitchell CJ, Churchward-Venne TA, Cameron-Smith D, Phillips SM. What is the relationship between the acute muscle protein synthesis response and changes in muscle mass? J Appl Physiol 118: 495-497, 2015.

33. Mitchell CJ, Churchward-Venne TA, Cameron-Smith D, Phillips SM. Last Word on Viewpoint: What is the relationship between the acute muscle protein synthetic response and changes in muscle mass? $\mathrm{J}$ Appl Physiol 118: 503, 2015.

34. Mitchell CJ, Churchward-Venne TA, Parise G, Bellamy L, Baker SK, Smith K, Atherton PJ, Phillips SM Acute Post-Exercise Myofibrillar Protein Synthesis Is Not Correlated with Resistance Training-Induced Muscle Hypertrophy in Young Men. PLoS ONE 9: e89431-7, 2014.

35. Moore DR, Tang JE, Burd NA, Rerecich T, Tarnopolsky MA, Phillips SM. Differential stimulation of myofibrillar and sarcoplasmic protein synthesis with protein ingestion at rest and after resistance exercise. J Physiol 587: 897-904, 2009.

36. Murphy $\mathrm{CH}$, Saddler NI, Devries MC, McGlory C, Baker SK, Phillips SM. Leucine supplementation enhances integrative myofibrillar protein synthesis in free-living older men consuming lower- and higherprotein diets: a parallel-group crossover study. Am J Clin Nutr 104: 1594-1606, 2016. 
37. Paddon-Jones D, Sheffield-Moore M, Katsanos CS, Zhang X-J, Wolfe RR. Differential stimulation of muscle protein synthesis in elderly humans following isocaloric ingestion of amino acids or whey protein. Exp Gerontol 41: 215-219, 2006.

38. Pennings B, Koopman R, Beelen M, Senden JMG, Saris WHM, van Loon LJC. Exercising before protein intake allows for greater use of dietary protein-derived amino acids for de novo muscle protein synthesis in both young and elderly men. Am J Clin Nutr 93: 322-331, 2011.

39. Phillips SM, Tipton KD, Aarsland A, Wolf SE, Wolfe RR. Mixed muscle protein synthesis and breakdown after resistance exercise in humans. Am J Physiol 273: E99-107, 1997.

40. Previs SF. Quantifying rates of protein synthesis in humans by use of $2 \mathrm{H} 2 \mathrm{O}$ : application to patients with end-stage renal disease. Am J Physiol Endocrinol Metab 286: E665-E672, 2004.

41. Reidy PT, Walker DK, Dickinson JM, Gundermann DM, Drummond MJ, Timmerman KL, Fry CS, Borack MS, Cope MB, Mukherjea R, Jennings K, Volpi E, Rasmussen BB. Protein Blend Ingestion Following Resistance Exercise Promotes Human Muscle Protein Synthesis. J Nutr 143: 410-416, 2013.

42. Reitelseder S, Agergaard J, Doessing S, Helmark IC, Lund P, Kristensen NB, Frystyk J, Flyvbjerg A, Schjerling P, van Hall G, Kjaer M, Holm L. Whey and casein labeled with L-[1-13C]leucine and muscle protein synthesis: effect of resistance exercise and protein ingestion. Am J Physiol Endocrinol Metab 300: E231-42, 2011.

43. Rennie MJ. An introduction to the use of tracers in nutrition and metabolism. Proc Nutr Soc 58: 935-944, 1999.

44. Robinson MM, Turner SM, Hellerstein MK, Hamilton KL, Miller BF. Long-term synthesis rates of skeletal muscle DNA and protein are higher during aerobic training in older humans than in sedentary young subjects but are not altered by protein supplementation. FASEB J 25: 3240-3249, 2011.

45. Scalzo RL, Peltonen GL, Binns SE, Shankaran M, Giordano GR, Hartley DA, Klochak AL, Lonac MC, Paris HLR, Szallar SE, Wood LM, Peelor FF, Holmes WE, Hellerstein MK, Bell C, Hamilton KL, Miller BF. Greater muscle protein synthesis and mitochondrial biogenesis in males compared with females during sprint interval training. FASEB J 28: 2705-2714, 2014.

46. Schwenk WF, Tsalikian E, Beaufrere B, Haymond MW. Recycling of an amino acid label with prolonged isotope infusion: implications for kinetic studies. Am J Physiol 248: E482-7, 1985.

47. Scrimgeour CM, Rollo MM, Mudambo SMKT, Handley LL, Prosser SJ. A simplified method for deuterium/hydrogen isotope ratio measurements on water samples of biological origin. Biological Mass Spectrometry 22: 383-387, 1993.

48. Smith Gl, Patterson BW, Mittendorfer B. Human muscle protein turnover--why is it so variable? J Appl Physiol 110: 480-491, 2011.

49. Symons TB, Sheffield-Moore M, Wolfe RR, Paddon-Jones D. A moderate serving of high-quality protein maximally stimulates skeletal muscle protein synthesis in young and elderly subjects. J Am Diet Assoc 109: 1582-1586, 2009.

50. Tsalikian E, Howard C, Gerich JE, Haymond MW. Increased leucine flux in short-term fasted human subjects: evidence for increased proteolysis. Am J Physiol 247: E323-7, 1984.

51. Wagenmakers AJ. Tracers to investigate protein and amino acid metabolism in human subjects. Proc Nutr Soc 58: 987-1000, 1999.

52. Wall BT, Dirks ML, Verdijk LB, Snijders T, Hansen D, Vranckx P, Burd NA, Dendale P, van Loon LJC. Neuromuscular electrical stimulation increases muscle protein synthesis in elderly type 2 diabetic men. Am J Physiol Endocrinol Metab 303: E614-23, 2012.

53. Wall BT, Hamer HM, de Lange A, Kiskini A, Groen BBL, Senden JMG, Gijsen AP, Verdijk LB, van Loon LJC. Leucine co-ingestion improves post-prandial muscle protein accretion in elderly men. Clin Nutr 32: 412-419, 2013.

54. Watt PW, Lindsay Y, Scrimgeour CM, Chien PA, Gibson JN, Taylor DJ, Rennie MJ. Isolation of aminoacyl-tRNA and its labeling with stable-isotope tracers: Use in studies of human tissue protein synthesis. Proc Natl Acad Sci USA 88: 5892-5896, 1991.

55. West DW, Burd NA, Coffey VG, Baker SK, Burke LM, Hawley JA, Moore DR, Stellingwerff T, Phillips SM. Rapid aminoacidemia enhances myofibrillar protein synthesis and anabolic intramuscular signaling responses after resistance exercise. Am J Clin Nutr 94: 795-803, 2011.

56. West DWD, Kujbida GW, Moore DR, Atherton P, Burd NA, Padzik JP, De Lisio M, Tang JE, Parise G, Rennie MJ, Baker SK, Phillips SM. Resistance exercise-induced increases in putative anabolic hormones do not enhance muscle protein synthesis or intracellular signalling in young men. J Physio/ 587: 52395247, 2009. 


\section{Chapter 7}

57. Wilkinson DJ, Franchi MV, Brook MS, Narici MV, Williams JP, Mitchell WK, Szewczyk NJ, Greenhaff $\mathrm{PL}$, Atherton PJ, Smith K. A validation of the application of D2O stable isotope tracer techniques for monitoring day-to-day changes in muscle protein subfraction synthesis in humans. Am J Physiol Endocrinol Metab 306: E571-E579, 2014.

58. Witard OC, Jackman SR, Breen L, Smith K, Selby A, Tipton KD. Myofibrillar muscle protein synthesis rates subsequent to a meal in response to increasing doses of whey protein at rest and after resistance exercise. Am J Clin Nutr 99: 86-95, 2014.

59. Witard OC, Tieland M, Beelen M, Tipton KD, van Loon LJC, Koopman R. Resistance exercise increases postprandial muscle protein synthesis in humans. Med Sci Sports Exerc 41: 144-154, 2009.

60. Wolfe RR, Song J, Sun J, Zhang X-J. Total aminoacyl-transfer RNA pool is greater in liver than muscle in rabbits. J Nutr 137: 2333-2338, 2007. 


\section{Chapter 8}

Protein supplementation after exercise and before sleep does not further augment muscle mass and strength gains during resistance exercise training in active older men

Andrew M. Holwerda, Maarten Overkamp, Kevin J. M. Paulussen, Joey S. J. Smeets, Janneau van Kranenburg, Evelien M.P. Backx, Annemie P. Gijsen, Joy P. B. Goessens, Lex B. Verdijk, and Luc J. C. van Loon

The Journal of Nutrition, 148(11), 1723-1732. 2018. 
Chapter 8

\section{Abstract}

Background The proposed benefits of protein supplementation on the skeletal muscle adaptive response to resistance exercise training in older adults remain unclear.

Objective The present study assessed whether protein supplementation after exercise and before sleep augments muscle mass and strength gains during resistance exercise training in older individuals.

Methods Forty-one older men (mean \pm SEM, age: $70 \pm 1$ y; body mass index: $25.3 \pm$ $0.4 \mathrm{~kg} \cdot \mathrm{m}^{-2}$ ) completed $12 \mathrm{wk}$ of whole-body resistance exercise training ( 3 sessions $\cdot \mathrm{wk}^{-1}$ ) and were randomly assigned to ingest either protein (21 $\mathrm{g}$ protein, $3 \mathrm{~g}$ total leucine, $9 \mathrm{~g}$ carbohydrate, $3 \mathrm{~g}$ fat; $n=21$ ) or an energymatched placebo ( $0 \mathrm{~g}$ protein, $25 \mathrm{~g}$ carbohydrate, $6 \mathrm{~g}$ fat; $n=20$ ) after exercise and each night before sleep. Maximal strength was assessed by 1 repetition-maximum (1RM) strength testing, and muscle hypertrophy was assessed at the whole-body (dual-energy X-ray absorptiometry), upper leg (computed tomography scan), and muscle fiber (biopsy) levels. Muscle protein synthesis rates were assessed during week 12 of training with the use of deuterated water $\left({ }^{2} \mathrm{H}_{2} \mathrm{O}\right)$ administration.

Results Leg-extension 1RM increased in both groups (placebo: $88 \pm 3$ to $104 \pm 4 \mathrm{~kg}$; protein: $85 \pm 3$ to $102 \pm 4 \mathrm{~kg} ; P<0.001$ ), with no differences between groups. Quadriceps cross-sectional area (placebo: $67.8 \pm 1.7$ to $73.5 \pm 2.0 \mathrm{~cm}^{2}$; protein: $68.4 \pm 1.4$ to $72.3 \pm 1.4 \mathrm{~cm}^{2} ; P<0.001$ ) increased in both groups, with no differences between groups. Muscle fiber hypertrophy occurred in type II (placebo: $5486 \pm 418$ to $6492 \pm 429 \mu m^{2}$; protein: $5367 \pm 301$ to 6259 $\pm 391 \mu \mathrm{m}^{2} ; P<0.001$ ), with no differences between groups. Muscle protein synthesis rates were $1.62 \pm 0.06$ and $1.57 \pm 0.05 \% \cdot d^{-1}$ in the placebo and protein groups, respectively, with no differences between groups.

Conclusions Protein supplementation after exercise and before sleep does not further augment skeletal muscle mass or strength gains during resistance exercise training in active older men. 


\section{Introduction}

The age-related decline in skeletal muscle mass and strength, termed sarcopenia, is accompanied by impairments in functional capacity and an increased risk of developing chronic metabolic diseases $(5,35)$. Physical activity, and resistance exercise in particular, may be the only effective strategy to increase muscle mass and strength. Meta-analyses have shown that protein supplementation may further augment the skeletal muscle adaptive response to resistance exercise training $(12,37)$. However, although some studies have shown greater increases in muscle mass, strength, or both after protein supplementation during resistance exercise training $(18,24,47,55)$, most individual studies have been unable to show such benefits of protein supplementation $(7,10,11,14,19,22,29,30,34,52)$. The apparent discrepancy between studies may be attributed to the differences in study design, including the population studied, the exercise training program, and characteristics of the protein supplementation regimen.

Over the past decade, the application of stable isotope tracer methodology has taught us that the postprandial stimulation of muscle protein synthesis is modulated by the type $(15$ $25,39,40,46,61)$, amount $(36,41,59-61)$, and timing $(1,31,57)$ of dietary protein ingestion. The ingestion of a rapidly digestible protein source (e.g., whey) has been shown to augment the muscle protein synthetic response when compared with more slowly digestible protein sources $(40,46,61)$. Furthermore, co-ingestion of free leucine has been shown to further augment the muscle protein synthetic response to protein ingestion in older individuals $(2$, $9,23,56)$. In addition to enhancing the muscle protein synthetic response to ingestion of the main meals, our laboratory has shown efficacy for dietary protein ingestion before sleep to increase overnight muscle protein synthesis rates $(16,27)$ and support recovery from resistance exercise $(20,43,51)$. We followed up on this work by showing that dietary protein ingestion before sleep augments muscle mass and strength gains during $12 \mathrm{wk}$ of resistance exercise training in healthy, younger men (45). Therefore, we hypothesized that leucineenriched whey protein supplementation, provided immediately after training and before sleep, would maximize the muscle protein synthetic response to exercise and, as such, further augment muscle mass and strength gains after more prolonged resistance exercise training in older individuals. 


\section{Materials and methods}

\section{Subjects}

A total of 44 healthy, normoglycemic older men volunteered to complete 12 wk of wholebody resistance exercise training $\left(3\right.$ sessions $\left.\cdot \mathrm{wk}^{-1}\right)$ and ingested either protein or an energymatched placebo after exercise and each night before sleep. Subjects' characteristics are presented in Table 8.1. All of the subjects were screened for medical issues and excluded if any gastrointestinal, cardiovascular, neurological, or renal diseases were present. Fasting and rested blood glucose and glycated hemoglobin were also assessed to screen for the presence of type 2 diabetes. Subjects were cleared to perform resistance exercise by a cardiologist who examined electrocardiograms measured at rest and during submaximal cycling (performed at $70 \%$ of age-predicted heart rate maximum). All of the subjects were living independently and had not been participating in any structured, progressive resistance exercise training program within the past $3 \mathrm{y}$. All of the subjects were informed of the nature and possible risks of the experimental procedures before their written informed consent was obtained. The study was approved by the Medical Ethical Committee of the Maastricht University Medical Center, Netherlands (METC 15-3-003) and conformed to standards for the use of human subjects in research as outlined in the most recent version of the Helsinki Declaration. This study was registered at the Netherlands Trial Registry (www.trialregister.nl) as NTR5082.

Table 8.1 Subjects' characteristics'

\begin{tabular}{|c|c|c|c|}
\hline & $\begin{array}{l}\text { Placebo group } \\
\qquad(n=20)\end{array}$ & $\begin{array}{l}\text { Protein-supplemented group } \\
\qquad(n=21)\end{array}$ & $P$ \\
\hline Age, $y$ & $71 \pm 1$ & $69 \pm 1$ & 0.10 \\
\hline Body mass, kg & $78.7 \pm 1.8$ & $77.4 \pm 1.9$ & 0.60 \\
\hline Height, m & $1.77 \pm 0.02$ & $1.74 \pm 0.01$ & 0.11 \\
\hline $\mathrm{BMI}, \mathrm{kg} \cdot \mathrm{m}^{-2}$ & $25.1 \pm 0.5$ & $25.5 \pm 0.6$ & 0.56 \\
\hline $\mathrm{SMI}, \mathrm{kg} \cdot \mathrm{m}^{-2}$ & $8.5 \pm 0.2$ & $8.6 \pm 0.1$ & 0.67 \\
\hline Leg volume, L & $8.6 \pm 0.2$ & $8.3 \pm 0.1$ & 0.42 \\
\hline Fasted plasma glucose, $\mathrm{mmol} \cdot \mathrm{L}^{-1}$ & $5.7 \pm 0.1$ & $5.7 \pm 0.1$ & 0.89 \\
\hline Fasted plasma insulin, $\mathrm{mU} \cdot \mathrm{L}^{-1}$ & $7.7 \pm 0.8$ & $9.8 \pm 1.3$ & 0.21 \\
\hline $\mathrm{HbA}_{1 \mathrm{c}}, \%$ & $5.6 \pm 0.1$ & $5.4 \pm 0.1$ & 0.13 \\
\hline HOMA-IR & $2.0 \pm 0.2$ & $2.5 \pm 0.4$ & 0.27 \\
\hline Systolic Blood Pressure, $\mathrm{mmHg}$ & $142 \pm 4$ & $142 \pm 3$ & 0.97 \\
\hline Diastolic Blood Pressure, $\mathrm{mmHg}$ & $75 \pm 2$ & $80 \pm 2$ & 0.07 \\
\hline Resting heart rate, BPM & $64 \pm 3$ & $61 \pm 1$ & 0.32 \\
\hline
\end{tabular}

${ }^{1}$ Values are means \pm SEMs. $n=20$ for placebo and $n=21$ for protein. 1RM: one repetition maximum, BMI: Body mass index, BPM: Beats per minute, HbA 1 : glycated hemoglobin, HOMA-IR: homeostatic model assessment of insulin resistance, SMI: Skeletal muscle mass index. Data were analyzed using a Student's unpaired t-test. No significant differences were detected between treatment groups. 


\section{Study design}

After inclusion in the study, subjects were randomly allocated in a double-blinded fashion to either a protein or a placebo group. Before and after the exercise training intervention, 2 separate experimental test days were performed within the same week. On the first experimental test day, anthropometric measurements (height, body mass, and leg volume), DXA, and computed tomography scans were performed and a muscle biopsy sample was collected. The second experimental test day was performed $4 \mathrm{~d}$ later and included an oralglucose-tolerance test (OGTT), short physical performance battery (SPPB) testing, and maximal strength assessments (1-repetition maximum (1RM) on leg press and leg extension). During week 12 of the training, deuterated water $\left({ }^{2} \mathrm{H}_{2} \mathrm{O}\right)$ was provided to assess myofibrillar protein synthesis rates.

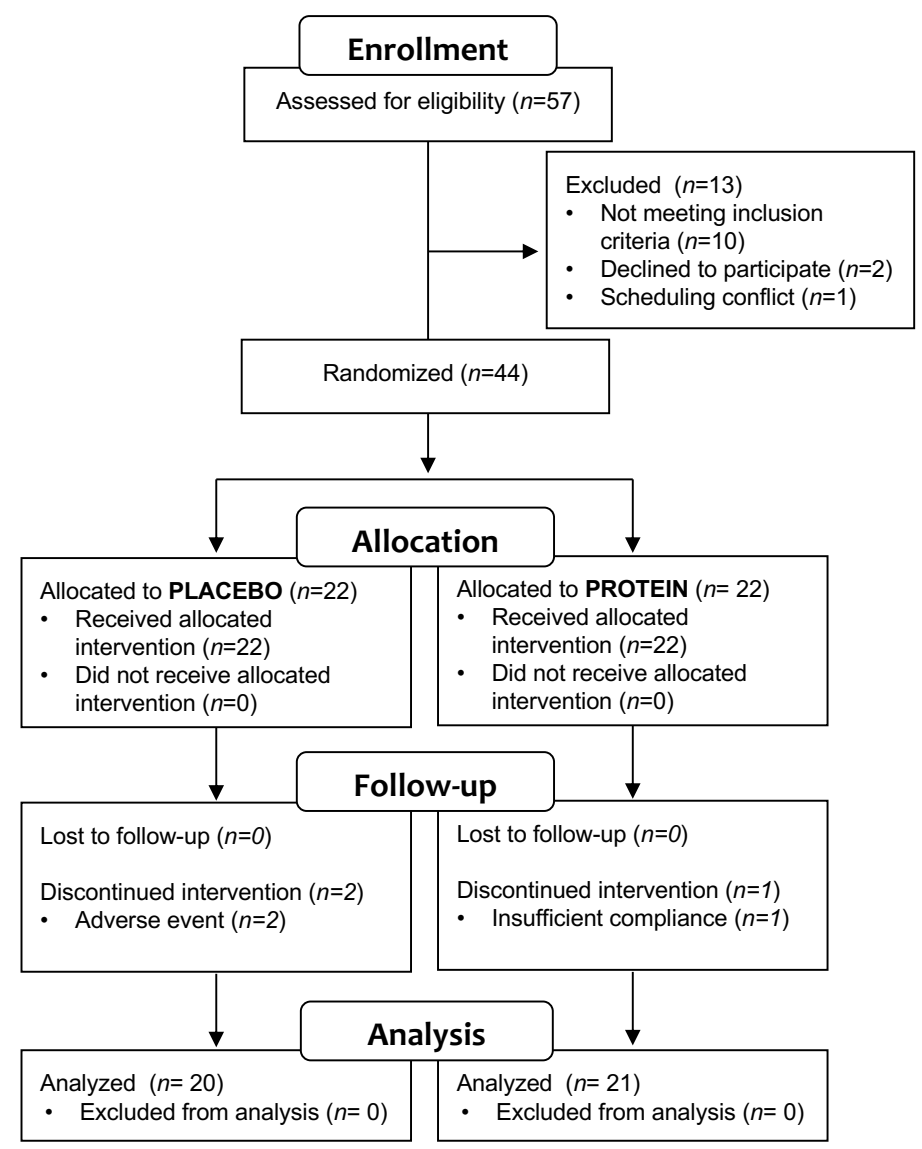

Figure 8.1 CONSORT (Consolidated Standards of Reporting Trials) flow diagram.

Diet and physical activity

All of the subjects were instructed to refrain from any exhaustive physical activity and to keep their diet as consistent as possible $72 \mathrm{~h}$ before the experimental test days. On all test days, the subjects arrived at the laboratory by car or public transportation in a fasting and rested state. Before the onset of training and during week 12 of training, subjects recorded $3-d$ 
dietary intake records to assess potential changes in daily food intake that might have occurred during the intervention period. Food intake records were evaluated by a dietitian and analyzed online with the use of a publicly available nutrition database (NEVO 2016).

\section{Exercise intervention}

Supervised whole-body resistance exercise training was performed 3 times $\cdot \mathrm{wk}^{-1}$ (Monday, Wednesday, and Friday) during the 12-wk exercise training intervention. All sessions were performed between 0800 and $1100 \mathrm{~h}$. Training consisted of a 5-min warm-up on a cycle ergometer, followed by a warm-up and 4 sets on both the leg press and leg extension machines. Upper body exercises were paired (chest press with lateral pulldown and shoulder press with horizontal row) and were performed in an alternating manner between training sessions, with 2 sets of each exercise performed. After training, subjects performed 5 min of cool-down on the cycle ergometer. During the first $4 \mathrm{wk}$ of training, the workload was increased from $70 \% 1 \mathrm{RM}$ ( 8 repetitions in each set) to $80 \% 1 \mathrm{RM}$ (10 repetitions). Resting periods of 2 and 3 min were allowed between sets and exercises, respectively. The workload was adjusted under the guidance of the investigators, which was primarily based on the 1RM estimations (weeks 0,4 , and 8 ). In addition, the workload was increased when $>10$ repetitions could be performed. Compliance with the resistance exercise training program was $95 \pm 1$ $\%$.

\section{Protein supplementation}

Subjects were randomly assigned to ingest either $21 \mathrm{~g}$ leucine-enriched whey protein $(3 \mathrm{~g}$ total leucine) or an energy-matched placebo after exercise and each night before sleep, including rest days. The nutritional composition of the test beverages is shown in Table 8.2. The intervention was performed in a double-blinded fashion whereby treatment randomization and beverage preparation and labeling were performed independent of the study team. Subjects received labeled packages containing dried contents of their randomly assigned beverages, which were dissolved in $250 \mathrm{~mL}$ water and ingested by the subjects. All of the beverages were flavored (vanilla or strawberry) to mask their contents. On training days, no food or drinks were allowed between breakfast and lunch other than the experimental beverages. The subjects were allowed to drink water before, during, and after each exercise session. Compliance to the supplementation was assessed by supplementation logs and was confirmed by counting returned supplement packages. Compliance for protein and placebo supplementation was $99.6 \pm 0.1 \%$. 
Table 8.2 Nutritional composition of the test beverages ingested in a double-blinded, randomized fashion after each resistance exercise training session and each night prior to sleep during 12 weeks of resistance exercise training in active older males ${ }^{1}$

\begin{tabular}{lcc}
\hline & & \\
Component & Protein $^{2}$ & Placebo $^{3}$ \\
\hline Energy, kJ & 628 & 628 \\
Energy, kcal & 150 & 150 \\
Protein, g & 20.7 & - \\
EAA, g & 10.6 & - \\
Leucine, g & 2.8 & - \\
Carbohydrate, g & 9.4 & 24.5 \\
Fat, g & 3 & 5.8 \\
Fibers, g & 1.3 & - \\
Cholecalciferol, $\mu \mathrm{g}$ & 20 & - \\
\hline
\end{tabular}

'Dissolved in $250 \mathrm{~mL}$ water. EAA: essential amino acids (Leu, Ile, Val, Phe, Met, His, Trp, Thr and Lys).

${ }^{2}$ The protein drink also contained other micronutrients: sodium (150 mg), potassium (279 mg), chloride (70 mg), calcium (500 mg), phosphorus (250 mg), magnesium (37 mg), iron (2.4 mg), zinc (2.2 mg), copper (270 $\mu \mathrm{g})$, manganese $(0.5 \mathrm{mg})$, fluoride $(0.15 \mathrm{mg})$, molybdenum $(15 \mu \mathrm{g})$, selenium $(15 \mu \mathrm{g})$, chromium $(7.5 \mu \mathrm{m})$, iodine (20 $\mu \mathrm{g})$, vitamin $A(152 \mu \mathrm{g})$, vitamin $E(7.5 \mathrm{mg})$, phylloquinone $(12 \mu \mathrm{g})$, thiamin $(0.23 \mathrm{mg})$, riboflavin $(0.25 \mathrm{mg})$, nicotinic acid $(8.8 \mathrm{mg})$, pantothenic acid $(0.81 \mathrm{mg})$, pyridoxine $(0.76 \mathrm{mg})$, folic acid $(203 \mu \mathrm{g})$, cyanocobalamin $(3 \mu \mathrm{g})$, biotin $(6.1 \mu \mathrm{g})$, ascorbic acid (32 mg), provitamin A carotenoids $(0.3 \mathrm{mg})$, and choline (56 $\mathrm{mg})$.

${ }^{3}$ The placebo drink also contained other micronutrients: sodium (123 mg), potassium (154 mg), chloride (329 mg), calcium $(0.71 \mathrm{mg})$, phosphorus $(0.3 \mathrm{mg})$, iodine $(0.3 \mu \mathrm{g})$.

\section{Body composition}

Body composition was measured at the whole- body and regional level using DXA (Discovery A; Hologic). Anthropometric measurements were assessed using standardized procedures, body mass by a digital scale to within $100 \mathrm{~g}$, and height by a stadiometer to within $0.5 \mathrm{~cm}$. Anatomic cross-sectional area (CSA) of the quadriceps muscle was assessed by computed tomography scanning (Philips Brilliance 64; Philips Medical Systems) before and after the 12 wk exercise training intervention, as described previously (3).

\section{Muscle biopsy sampling}

Muscle biopsy samples were obtained from the middle region of the $M$. vastus lateralis, 15 $\mathrm{cm}$ above the patella and $4 \mathrm{~cm}$ below entry through the fascia, using the percutaneous needle biopsy technique (8). Muscle samples were prepared for analyses as previously described (45). 
Immunohistochemistry

Muscle biopsy specimens were sliced into 5-mm-thick cryo-sections and stained for muscle fiber type, and type I and II muscle fiber CSA and composition were determined as described in detail previously $(30,52)$. No differences in fiber circularity were observed in response to training or between groups. The mean fiber numbers included in analyses were $206 \pm 16$ and $161 \pm 11$ from the muscle biopsy samples collected before and after the 12-wk training intervention, respectively.

\section{Myofibrillar fractional synthesis rates}

Deuterated water $\left({ }^{2} \mathrm{H}_{2} \mathrm{O}\right)$ was provided throughout week 12 of exercise training to assess average daily myofibrillar protein synthesis rates as described previously (21). In short, subjects ingested $400 \mathrm{~mL}$ of $70 \%$ deuterated water spread evenly over a 12-h period on the Friday of week 11 of the training intervention. Subjects ingested $50 \mathrm{~mL}$ of $70 \%$ deuterated water in the morning of each of the 10 remaining days of the intervention period to maintain the body water deuterium enrichment. A muscle biopsy sample was collected in the morning before the Monday training of week 12. Myofibrillar proteins were isolated from this muscle biopsy sample and from the post-training muscle biopsy sample collected the following Monday, and the increase in ${ }^{2} \mathrm{H}$-alanine enrichment was assessed by using GC-pyrolysis-IRMS (21). Samples were measured in quadruplicate along with a series of known standards every 12 injections. Myofibrillar protein synthesis rates were calculated as previously described (21).

\section{Muscle strength and physical performance}

Maximal strength was assessed by 1RM strength tests on leg press and leg extension machines (Technogym) before and after the training intervention. During the subject intake visit, proper lifting technique was demonstrated and practiced and maximal strength was estimated by using the multiple repetitions testing procedure (33). On the second experimental test day, each subject's 1 RM was determined as described previously (53). To ensure progressive loading during training, 1RM was estimated at the end of weeks 4 and 8. Post-training maximal strength was assessed $7 \mathrm{~d}$ after the last training session. Physical performance was assessed by the SPPB, which consists of 3 components: balance, gait speed, and chair-rise ability (17).

\section{Glucose tolerance and plasma hormone concentrations}

A standard OGTT was performed before and after the training intervention, as described previously (30). Testosterone, free testosterone, growth hormone, insulin-like growth factor 
I (IGF-I), and sex hormone-binding globulin (SHBG) were assessed in serum samples collected in a resting and fasting state before and after the training intervention. Serum testosterone was measured by using an electrochemiluminescent immunoassay (Cobas 8000 instrument; Roche Diagnostics). Growth hormone and IGF-I were measured by using a chemiluminescent immunometric assay (IDS iSYS instrument; Immunodiagnostic Systems). SHBG was determined in serum by using a chemiluminescent immunometric assay (XPi instrument; Siemens Medical Solutions Diagnostics). Free testosterone was calculated according to Vermeulen et al. (54).

\section{Statistics}

All of the data are expressed as means \pm SEMs. Baseline characteristics between groups were compared by using a Student's unpaired t-test. A 2-factor repeated-measures ANOVA (time $\times$ treatment) with time (pre-post) as a within-subjects factor and treatment group (placebo-protein) as a between-subjects factor was performed for the analysis of dietary intake, appendicular lean body mass, quadriceps CSA, muscle fiber CSA, muscle strength and performance measures, serum hormone concentrations, and the AUC of glucose and insulin concentrations during the OGTT. In case of a significant interaction, Student's paired t-tests were performed to determine time effects within groups. Myofibrillar protein synthesis rates were compared between groups by using a Student's unpaired $t$-test. Significance was set at $P<0.05$. All calculations were performed with the use of SPSS (version 21.0; IBM Corporation). 


\section{Results}

\section{Subjects}

Subjects' characteristics are presented in Table 8.1. In total, 44 subjects were included in the experimental protocol. Three subjects were excluded from analyses; one was excluded due to insufficient exercise compliance ( $>6$ missed sessions), one dropped out due to knee aggravation, and one dropped out due to an adverse event that occurred during a training session. Therefore, analysis was performed in 41 subjects, 20 in the placebo group and 21 in the protein group. Training volume load throughout the entire training intervention did not differ between the placebo and protein groups for any of the exercises performed. At baseline, no differences in age, body mass, height, BMI, skeletal muscle mass index, or leg volume were observed between the placebo and protein groups (Table 8.1). We observed a significant increase in body mass in response to $12 \mathrm{wk}$ of resistance exercise training $(P<$ $0.001)$, with a greater increase observed in the placebo group $(P=0.007)$. We observed a significant increase in $\mathrm{BMI}$ in response to 12 wk of resistance exercise training $(P<0.001)$, with a greater increase observed in the placebo group $(P=0.008)$.

Table 8.3 Energy intake and macronutrient composition of the diet before and after 12 weeks of resistance exercise training in active older men who did or did not receive protein supplementation ${ }^{1}$

\begin{tabular}{|c|c|c|c|c|c|c|c|}
\hline & \multicolumn{2}{|c|}{$\begin{array}{l}\text { Placebo group } \\
(n=20)\end{array}$} & \multicolumn{2}{|c|}{$\begin{array}{l}\text { Protein-supplemented group } \\
\qquad(n=21)\end{array}$} & \multicolumn{3}{|c|}{$P$} \\
\hline & $0 \mathrm{wk}$ & $12 \mathrm{wk}$ & $0 \mathrm{wk}$ & $12 \mathrm{wk}$ & $\begin{array}{c}\text { Treatment } \mathrm{x} \text { Time } \\
\text { Interaction }\end{array}$ & $\begin{array}{l}\text { Treatment } \\
\text { Effect }\end{array}$ & $\begin{array}{c}\text { Time } \\
\text { Effect }\end{array}$ \\
\hline Diet & $9.7 \pm 0.5$ & $10.3 \pm 0.5$ & $9.4 \pm 0.4$ & $9.1 \pm 0.3$ & 0.062 & 0.151 & 0.525 \\
\hline Total & $9.7 \pm 0.5$ & $11.2 \pm 0.5^{\star}$ & $9.4 \pm 0.4$ & $10.0 \pm 0.3^{*}$ & 0.062 & 0.151 & $<0.001$ \\
\hline Diet & $93 \pm 4$ & $94 \pm 4$ & $87 \pm 3$ & $81 \pm 3$ & 0.153 & 0.052 & 0.299 \\
\hline Total & $93 \pm 4$ & $94 \pm 4$ & $87 \pm 3$ & $111 \pm 3^{*}$ & $<0.001$ & 0.204 & $<0.001$ \\
\hline \multicolumn{8}{|l|}{ Protein intake, $\mathrm{g} \cdot \mathrm{kg} \mathrm{BM} \cdot \mathrm{d}^{-1}$} \\
\hline Diet & $1.19 \pm 0.06$ & $1.17 \pm 0.06$ & $1.14 \pm 0.05$ & $1.04 \pm 0.04$ & 0.164 & 0.191 & 0.061 \\
\hline Total & $1.19 \pm 0.06$ & $1.17 \pm 0.06$ & $1.14 \pm 0.05$ & $1.43 \pm 0.04^{\star}$ & $<0.001$ & 0.138 & $<0.001$ \\
\hline Fat intake, total, $\mathbf{g} \cdot \mathrm{d}^{-1}$ & $89 \pm 6$ & $98 \pm 7$ & $86 \pm 4$ & $80 \pm 5$ & 0.045 & 0.168 & 0.701 \\
\hline Fat intake, total, En\% & $34 \pm 1$ & $32 \pm 1$ & $34 \pm 1$ & $30 \pm 1$ & 0.336 & 0.331 & 0.005 \\
\hline Carbohydrate intake, total, $g \cdot d^{-1}$ & $242 \pm 16$ & $303 \pm 16^{*}$ & $235 \pm 13$ & $253 \pm 11^{*}$ & 0.022 & 0.11 & $<0.001$ \\
\hline Carbohydrate intake, total, En\% & $42 \pm 1$ & $45 \pm 2$ & $42 \pm 1$ & $43 \pm 1$ & 0.137 & 0.531 & 0.093 \\
\hline \multicolumn{8}{|l|}{ Vitamin D intake, $\mu \mathrm{g} \cdot \mathrm{d}^{-1}$} \\
\hline Diet & $3.7 \pm 0.5$ & $3.8 \pm 0.7$ & $3.5 \pm 0.4$ & $3.0 \pm 0.03$ & 0.531 & 0.314 & 0.624 \\
\hline Total & $3.7 \pm 0.5$ & $3.8 \pm 0.7$ & $3.5 \pm 0.4$ & $31.6 \pm 0.3^{*}$ & $<0.001$ & $<0.001$ & $<0.001$ \\
\hline
\end{tabular}

'Values are means \pm SEMs. Diet: only dietary intake data, Total: dietary intake plus protein or placebo supplementation, BM: Body mass, En\%: Energy Percentage. * Significantly different from $0 w k(P<0.05)$. 
Dietary intake

Dietary intake data are shown in Table 8.3. Analysis of the 3-d dietary intake records collected before and during week 12 of the experimental protocol showed no baseline differences in total daily energy intake between groups but an increase during the intervention $(P<0.001)$. Dietary macronutrient composition did not differ at baseline between groups and did not change during the experimental protocol (Table 8.3). In particular, daily protein intake from the diet averaged $1.2 \pm 0.1$ and $1.1 \pm 0.1 \mathrm{~g} \cdot \mathrm{kg}^{-1} \cdot \mathrm{d}^{-1}$ at baseline in the placebo and protein groups, respectively, and did not change during the training intervention. Supplementation caused daily protein intake relative to body mass to significantly increase in the protein group when compared with the placebo group (treatment $\times$ time interaction, $P<0.001$ ). Supplementation also resulted in greater daily vitamin $D$ intake in the protein group than in the placebo group (treatment $\times$ time interaction, $P<0.001$ ).

Table 8.4 Body composition before and after 12 weeks of resistance exercise training in active older men who did or did not receive protein supplementation ${ }^{1}$

\begin{tabular}{|c|c|c|c|c|c|c|c|c|c|}
\hline & \multicolumn{3}{|c|}{$\begin{array}{l}\text { Placebo group } \\
\quad(n=20)\end{array}$} & \multicolumn{3}{|c|}{$\begin{array}{l}\text { Protein-supplemented group } \\
\qquad(n=21)\end{array}$} & \multicolumn{3}{|c|}{$P$} \\
\hline & 0 wk & $12 \mathrm{wk}$ & Difference & 0 wk & $12 \mathrm{wk}$ & Difference & $\begin{array}{l}\text { Treatment } \\
\text { x Time } \\
\text { Interaction }\end{array}$ & $\begin{array}{l}\text { Treatment } \\
\text { Effect }\end{array}$ & $\begin{array}{l}\text { Time } \\
\text { Effect }\end{array}$ \\
\hline Body mass, $\mathrm{kg}$ & $78.7 \pm 1.8$ & $80.5 \pm 1.8^{\star}$ & $+1.8 \pm 0.3$ & $77.4 \pm 1.9$ & $78.1 \pm 1.8^{\star}$ & $+0.8 \pm 0.2$ & 0.007 & 0.463 & $<0.001$ \\
\hline Height, m & $1.77 \pm 0.02$ & $1.77 \pm 0.02$ & $0 \pm 0$ & $1.74 \pm 0.01$ & $1.74 \pm 0.01$ & $0 \pm 0$ & ---- & 0.11 & ---- \\
\hline $\mathrm{BMI}, \mathrm{kg} \cdot \mathrm{m}^{-2}$ & $25.1 \pm 0.5$ & $25.6 \pm 0.5^{\star}$ & $0.6 \pm 0.1$ & $25.5 \pm 0.6$ & $25.8 \pm 0.6^{\star}$ & $0.3 \pm 0.1$ & 0.008 & 0.695 & $<0.001$ \\
\hline LBM, kg & $60.8 \pm 1.3$ & $62.4 \pm 1.3$ & $+1.6 \pm 0.3$ & $59.2 \pm 1.1$ & $60.2 \pm 1.2$ & $+1.1 \pm 0.2$ & 0.183 & 0.278 & $<0.001$ \\
\hline Appendicular LBM, kg & $26.7 \pm 0.7$ & $27.7 \pm 0.7$ & $+1.0 \pm 0.2$ & $26.0 \pm 0.5$ & $26.6 \pm 0.5$ & $+0.6 \pm 0.1$ & 0.126 & 0.303 & $<0.001$ \\
\hline Leg lean mass, kg & $13.4 \pm 0.4$ & $13.9 \pm 0.4$ & $+0.7 \pm 0.1$ & $13.0 \pm 0.2$ & $13.4 \pm 0.2$ & $+0.4 \pm 0.1$ & 0.146 & 0.316 & $<0.001$ \\
\hline Fat mass, kg & $16.7 \pm 1.0$ & $16.3 \pm 0.9$ & $-0.5 \pm 0.2$ & $16.8 \pm 0.9$ & $16.2 \pm 0.8$ & $-0.6 \pm 0.2$ & 0.690 & 0.999 & $<0.001$ \\
\hline Body fat percentage, $\%$ & $20.7 \pm 0.9$ & $19.8 \pm 0.9$ & $-0.9 \pm 0.3$ & $21.1 \pm 0.7$ & $20.3 \pm 0.7$ & $-0.8 \pm 0.2$ & 0.880 & 0.679 & $<0.001$ \\
\hline Bone mineral content, $\mathrm{g}$ & $2925 \pm 69$ & $2918 \pm 69$ & $-8 \pm 14$ & $2727 \pm 72$ & $2698 \pm 69$ & $-30 \pm 14$ & 0.279 & 0.040 & 0.069 \\
\hline Bone mineral density, $\mathrm{g} \cdot \mathrm{cm}^{-2}$ & $1.24 \pm 0.03$ & $1.23 \pm 0.03$ & $-0.01 \pm 0.01$ & $1.18 \pm 0.02$ & $1.18 \pm 0.02$ & $-0.01 \pm 0.01$ & 0.921 & 0.100 & 0.527 \\
\hline
\end{tabular}

${ }^{1}$ Values are means \pm SEMs. BMI: Body mass index, LBM: Lean body mass. *Significantly different from 0 wk $(P<$ 0.05).

\section{Body composition}

At baseline, no significant differences in body-composition measurements were observed between the placebo and protein groups (Table 8.4). Whole-body lean mass significantly increased in response to $12 \mathrm{wk}$ of resistance exercise training in the placebo and the protein groups $(P<0.001)$, with no differences between groups. In accordance, appendicular lean mass and leg lean mass significantly increased in response to $12 \mathrm{wk}$ of resistance exercise training in the placebo and protein groups $(P<0.001)$, with no differences between groups. Whole-body fat mass and body fat percentage declined in response to $12 \mathrm{wk}$ of resistance 
exercise training in the placebo and protein groups $(P<0.001)$, with no differences between groups.

\section{Skeletal muscle hypertrophy}

At baseline, no significant differences in quadriceps muscle CSA were observed between the placebo and protein groups (Figure 8.2). Quadriceps muscle CSA increased in response to $12 \mathrm{wk}$ of resistance exercise training (Figure 8.2; $P<0.001$ ), with no differences between groups. Before training, no significant differences were observed in type I and type II muscle fiber size between placebo and protein groups. Type I muscle fiber CSA (Figure 8.3A) did not change in response to $12 \mathrm{wk}$ of resistance exercise training in both the placebo and protein groups. Type II muscle fiber CSA (Figure 8.3B) increased in response to 12 wk of resistance exercise training in both groups $(P<0.001)$, with no differences between groups.

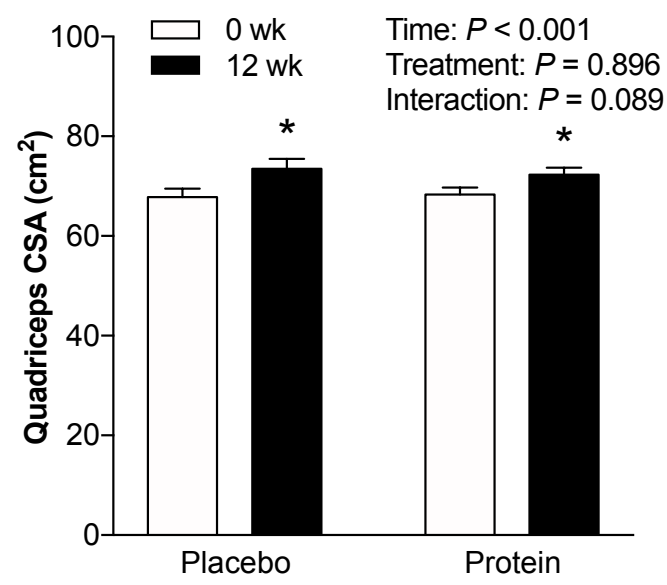

Figure 8.2 Quadriceps muscle cross-sectional area (CSA) before and after 12 weeks of resistance exercise training in active older men who did or did not receive protein supplementation. Values are means $\pm S E M s, n$ = 20 (placebo) or 21 (protein). Data were analyzed using a two-way ANOVA. CSA: cross-sectional area. *Significantly different from values prior to exercise training $(P<0.05)$.
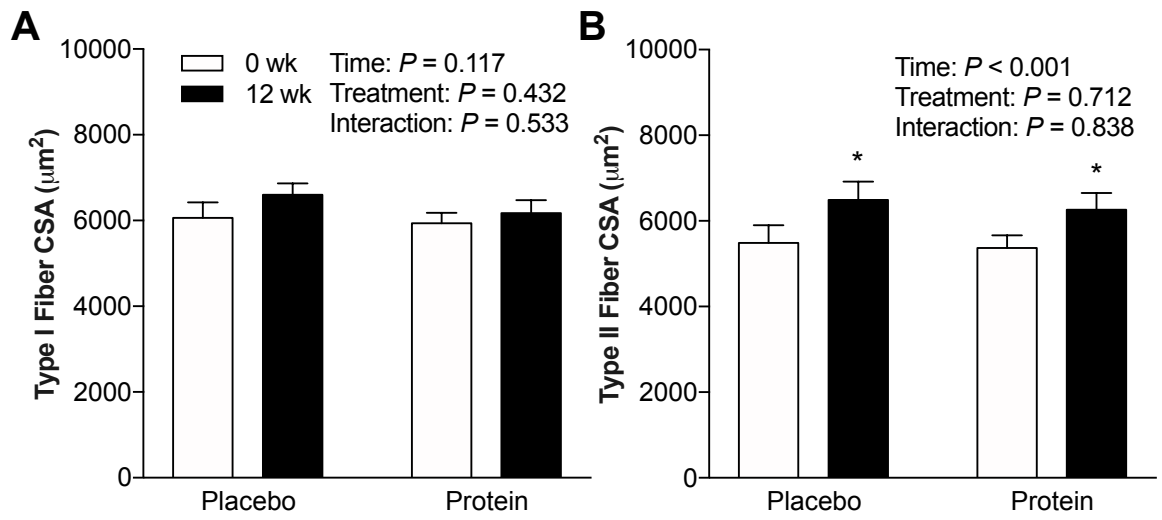

Figure 8.3 Type I (A) and Type II (B) muscle fiber cross-sectional area (CSA) before and after 12 weeks of resistance exercise training in active older men who did or did not receive protein supplementation. Values are means \pm SEMs, $n=20$ (placebo) or 20 (protein). Data were analyzed using a two-way ANOVA. *Significantly different from values prior to exercise training $(P<0.05)$. 


\section{Muscle fiber-type composition}

At baseline, no significant differences in the percentage of type I and type II muscle fibers and percentage of CSA occupied by type I and II muscle fibers were observed between the placebo and protein groups (Table 8.5). The percentage of type I and type II muscle fibers and the percentage of CSA occupied by type I and II muscle fibers did not change in response to $12 \mathrm{wk}$ of resistance exercise training in either group.

Table 8.5 Muscle fiber type composition before and after 12 weeks of resistance exercise training in active older men who did or did not receive protein supplementation

\begin{tabular}{|c|c|c|c|c|c|c|c|}
\hline & \multicolumn{2}{|c|}{$\begin{array}{l}\text { Placebo group } \\
\quad(n=20)\end{array}$} & \multicolumn{2}{|c|}{$\begin{array}{l}\text { Protein-supplemented group } \\
\qquad(n=20)\end{array}$} & \multicolumn{3}{|c|}{$P$} \\
\hline & $0 \mathrm{wk}$ & $12 \mathrm{wk}$ & $0 \mathrm{wk}$ & $12 \mathrm{wk}$ & $\begin{array}{c}\text { Treatment } \\
\text { x Time } \\
\text { Interaction }\end{array}$ & $\begin{array}{l}\text { Treatment } \\
\text { Effect }\end{array}$ & Time Effect \\
\hline Type I Fibers, \% & $50 \pm 4$ & $48 \pm 3$ & $55 \pm 4$ & $53 \pm 3$ & 0.737 & 0.252 & 0.432 \\
\hline Type II Fibers, \% & $50 \pm 4$ & $52 \pm 3$ & $45 \pm 4$ & $47 \pm 3$ & 0.737 & 0.252 & 0.432 \\
\hline Type II CSA, \% & $48 \pm 4$ & $51 \pm 4$ & $42 \pm 4$ & $48 \pm 3$ & 0.662 & 0.326 & 0.161 \\
\hline
\end{tabular}

${ }^{1}$ Values are means \pm SEMs. CSA: cross-sectional area.

Myofibrillar protein synthesis rates

Myofibrillar protein synthesis rates during week 12 of the training protocol were assessed by administration of deuterated water and by measuring myofibrillar protein-bound $\left[{ }^{2} \mathrm{H}\right]$-alanine enrichments in muscle biopsy samples collected on Monday of week 12 and the following Monday (post-training muscle biopsy sample). Body water deuterium enrichment over the 7 - $d$ assessment period averaged $0.75 \pm 0.01 \%$ in both groups, with no differences between groups. The increase in myofibrillar protein-bound $\left[{ }^{2} \mathrm{H}\right]$-alanine enrichments averaged 0.315 \pm 0.015 and $0.308 \pm 0.016$ mole percent excess (MPE) in the placebo group and protein group, respectively. Myofibrillar protein synthesis rates (Figure 8.4) were not different between groups. 


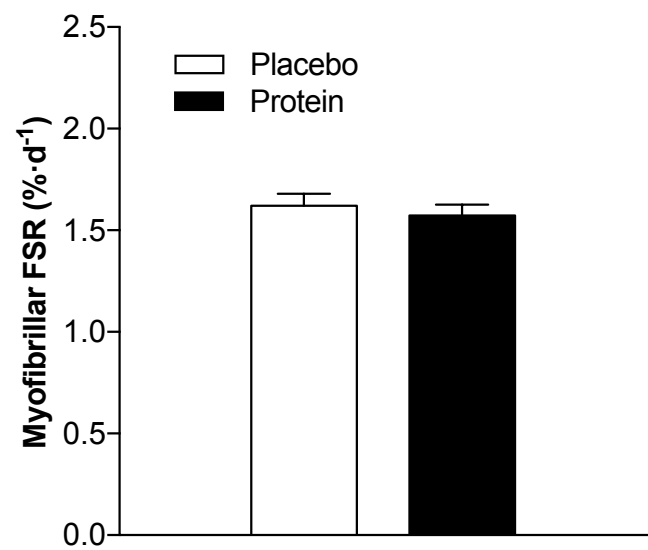

Figure 8.4 Fractional myofibrillar protein synthesis rates (FSR) assessed throughout week 12 of the resistance exercise training intervention in active older men who did or did not receive protein supplementation. Values are means \pm SEMs, $n=20$ (placebo) or 21 (protein). Data were analyzed using a Student's unpaired t-test.

\section{Muscle strength and physical performance}

At baseline, no significant differences in leg extension or leg press 1RM (Table 8.6) were observed between the placebo and protein groups. Leg press and leg extension 1RM significantly increased in both groups $(P<0.001)$ in response to $12 \mathrm{wk}$ of resistance exercise training, with no differences detected between groups. Likewise, physical performance (SPPB) scores (Table 8.6; $P<0.01$ ) and sit-to-stand time decreased in response to $12 \mathrm{wk}$ of resistance exercise training (Table 8.6; $P<0.001$ ), with no differences between groups.

Table 8.6 Muscle strength and physical performance before and after 12 weeks of resistance exercise training in active older men who did or did not receive protein supplementation ${ }^{1}$

\begin{tabular}{|c|c|c|c|c|c|c|c|c|c|}
\hline & \multicolumn{3}{|c|}{$\begin{array}{l}\text { Placebo group } \\
\quad(n=19)\end{array}$} & \multicolumn{3}{|c|}{$\begin{array}{l}\text { Protein-supplemented group } \\
\qquad(n=21)\end{array}$} & \multicolumn{3}{|c|}{$P$} \\
\hline & $0 w k$ & $12 \mathrm{wk}$ & Difference & $0 \mathrm{wk}$ & $12 \mathrm{wk}$ & Difference & $\begin{array}{c}\text { Treatment } \\
\text { x Time } \\
\text { Interaction }\end{array}$ & $\begin{array}{l}\text { Treatment } \\
\text { Effect }\end{array}$ & $\begin{array}{c}\text { Time } \\
\text { Effect }\end{array}$ \\
\hline Leg press $1 \mathrm{RM}, \mathrm{kg}$ & $162 \pm 6$ & $188 \pm 7$ & $+25 \pm 3$ & $157 \pm 5$ & $180 \pm 6$ & $+24 \pm 3$ & 0.765 & 0.397 & $<0.001$ \\
\hline Leg extension $1 \mathrm{RM}, \mathrm{kg}$ & $88 \pm 3$ & $105 \pm 4$ & $+16 \pm 3$ & $85 \pm 3$ & $102 \pm 4$ & $+17 \pm 3$ & 0.798 & 0.481 & $<0.001$ \\
\hline $4 \mathrm{~m}$ walking test, $\mathrm{s}$ & $3.57 \pm 0.12$ & $3.60 \pm 0.09$ & $+0.03 \pm 0.11$ & $3.70 \pm 0.08$ & $3.72 \pm 0.11$ & $+0.03 \pm 0.09$ & 0.877 & 0.273 & 0.604 \\
\hline Sit-stand test time, $\mathrm{s}$ & $12.03 \pm 0.31$ & $11.20 \pm 0.32$ & $-0.83 \pm 0.37$ & $11.57 \pm 0.27$ & $10.80 \pm 0.27$ & $-0.77 \pm 0.25$ & 0.739 & 0.233 & $<0.001$ \\
\hline
\end{tabular}

${ }^{1}$ Values are means \pm SEMs. 1RM: one-repetition maximum, SPPB: Short physical performance battery.

\section{Glucose tolerance}

Glucose and insulin concentrations during the OGTT are shown in Figure 8.5A. Glucose tolerance improved in response to $12 \mathrm{wk}$ of resistance exercise training, as shown by a significant reduction in plasma glucose AUC during the OGTT (Figure 8.5B; $P=0.027$ ), with no differences for plasma insulin $A U C$ and no differences observed between groups. 

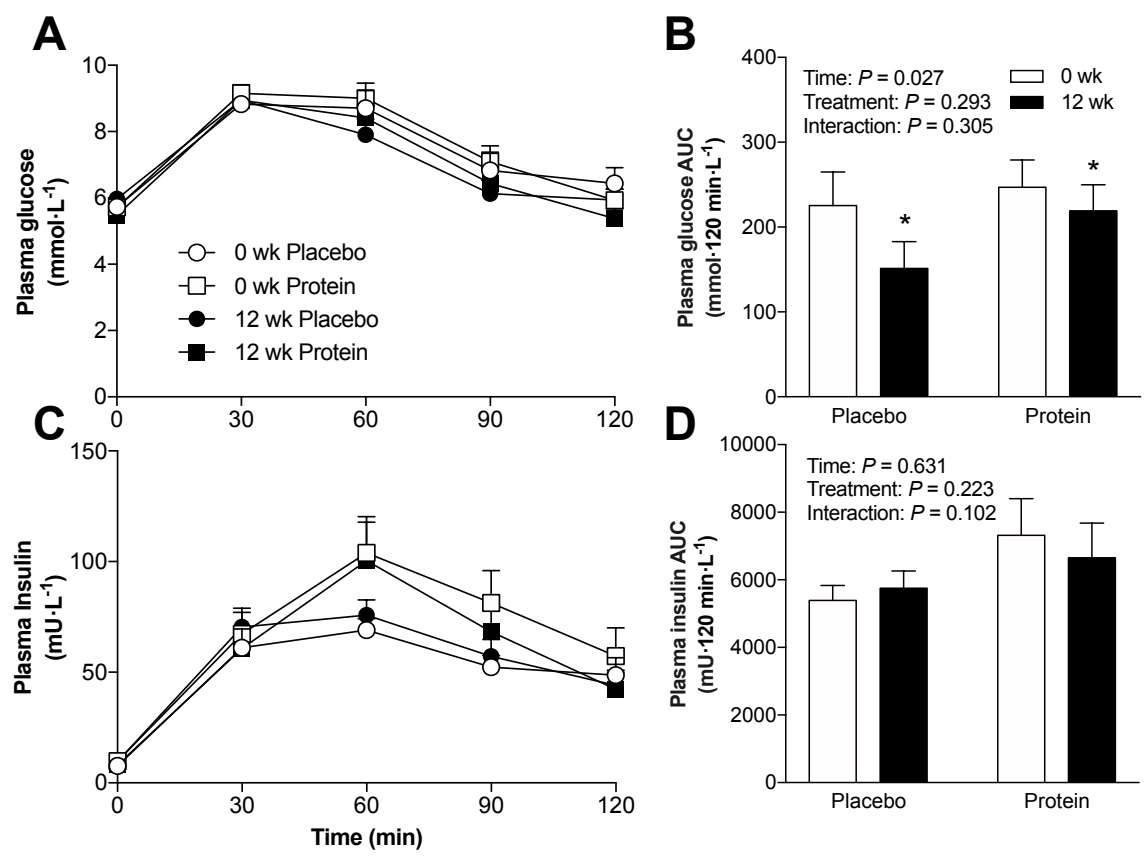

Figure 8.5 Plasma glucose $(A)$ and insulin (C) concentrations and areas under the curve ( $A \cup C ; B$ and $D$ ) in response to an oral glucose tolerance test (OGTT) before and after 12 weeks of resistance exercise training in active older men who did or did not receive protein supplementation. Values are means $\pm S E M s, n=20$ (placebo) or 21 (protein). Data for AUCs were analyzed using a two-way ANOVA. *Significantly different from values prior to exercise training $(P<0.05)$.

\section{Plasma hormone concentrations}

Serum testosterone, free testosterone, growth hormone, IGF-I, and SHBG concentrations are shown in Table 8.7. Plasma hormone concentrations did not differ between groups and did not change in response to $12 \mathrm{wk}$ of resistance exercise training.

Table 8.7 Fasting serum hormone concentrations before and after 12 weeks of resistance exercise training in active older men who did or did not receive protein supplementation ${ }^{1}$

\begin{tabular}{|c|c|c|c|c|c|c|c|c|c|}
\hline & \multicolumn{3}{|c|}{$\begin{array}{l}\text { Placebo group } \\
(n=20)\end{array}$} & \multicolumn{3}{|c|}{$\begin{array}{l}\text { Protein-supplemented group } \\
\qquad(n=21)\end{array}$} & \multicolumn{3}{|c|}{$P$} \\
\hline & $0 \mathrm{wk}$ & $12 \mathrm{wk}$ & Difference & $0 \mathrm{wk}$ & $12 w k$ & Difference & $\begin{array}{l}\text { Treatment } \\
\text { x Time } \\
\text { Interaction }\end{array}$ & $\begin{array}{l}\text { Treatment } \\
\text { Effect }\end{array}$ & $\begin{array}{l}\text { Time } \\
\text { Effect }\end{array}$ \\
\hline Testosterone, $\mathrm{nmol} \cdot \mathrm{L}^{-1}$ & $17.7 \pm 1.8$ & $18.5 \pm 1.8$ & $+0.8 \pm 1.0$ & $16.0 \pm 1.2$ & $16.8 \pm 1.4$ & $+0.7 \pm 0.9$ & 0.972 & 0.534 & 0.258 \\
\hline Free testosterone, $\mathrm{pmol} \cdot \mathrm{L}^{-1}$ & $247 \pm 18$ & $251 \pm 15$ & $+5 \pm 13$ & $242 \pm 15$ & $262 \pm 19$ & $+17 \pm 14$ & 0.509 & 0.867 & 0.258 \\
\hline $\mathrm{SHBG}, \mathrm{nmol} \cdot \mathrm{L}^{-1}$ & $50.3 \pm 3.9$ & $51.9 \pm 3.9$ & $+1.5 \pm 1.2$ & $44.3 \pm 3.6$ & $43.1 \pm 3.5$ & $-1.2 \pm 1.0$ & 0.062 & 0.284 & 0.629 \\
\hline
\end{tabular}

${ }^{1}$ Values are means \pm SEMs. IGF-1: Insulin-like growth factor 1, SHBG: Sex hormone binding globulin. 


\section{Discussion}

The present study shows that $12 \mathrm{wk}$ of resistance exercise training increased muscle mass and strength in active older men. Protein supplementation after each exercise session (3 times $\cdot \mathrm{wk}^{-1}$ ) and every night before sleep did not further enhance the training-induced gains in skeletal muscle mass or strength in older men.

Twelve weeks of progressive whole-body resistance exercise training resulted in a combined average gain of $1.3 \pm 0.2 \mathrm{~kg}$ lean body mass and a concomitant decrease in whole-body fat mass. These results are in line with previous studies that showed that $12 \mathrm{wk}$ of resistance exercise training results in a gain of approximately $1.0 \mathrm{~kg}$ lean body mass $(10,30,37,52)$. The increase in lean body mass primarily occurred in the lower extremities, with quadriceps CSA being increased by $7 \pm 1 \%$. This increase in muscle mass was accompanied by $15 \pm 1$ $\%$ and $21 \pm 3 \%$ increases in leg press and leg extension strength, respectively. As expected, our findings are in line with previous studies that showed strength increases of $\geq 25 \%$ after a 12 -wk resistance exercise training program $(26,30,32,52)$. The observed increase in muscle strength and shift in body composition also contributed to improvements in functional capacity (Table 8.6) and oral glucose tolerance (Figure 8.5).

In the present study, we tested the hypothesis that supple- mentation with leucine-enriched whey protein ingested after each exercise session and every night before sleep would further augment gains in muscle mass and strength during resistance exercise training in active older men. Despite the significant gains in lean body mass observed over the course of the training period, we observed no differences between the protein- supplemented and placebo groups ( $1.1 \pm 0.2$ and $1.6 \pm 0.3 \mathrm{~kg}$, respectively; $P=0.18)$. These findings correspond with more direct assessments of skeletal muscle hypertrophy, because we observed no differences between groups in quadriceps CSA (Figure 8.2; $P=0.09$ ) or type I (Figure 8.3A; $P=0.53$ ) and type II (Figure 8.3B; $P=0.84$ ) muscle fiber CSA. We also observed no differences in leg press $1 \mathrm{RM}$ (Table 8.6; $P=0.77$ ), leg extension 1RM (Table 8.6; $P=0.80$ ), or sit-to-stand time (Table 8.6; $P=0.74$ ) between groups.

In addition to our assessments of skeletal muscle mass and strength, we also provided subjects with deuterated water $\left({ }^{2} \mathrm{H}_{2} \mathrm{O}\right)$ to assess the muscle protein synthetic response to protein supplementation throughout the last week of the training intervention. With the use of this approach, we and others have shown that resistance exercise stimulates a robust increase in muscle protein synthesis rates over days or weeks $(21,44,58)$. In line with the present findings on muscle mass, we observed no differences in myofibrillar protein synthesis rates between the placebo and protein groups. Daily fractional muscle protein synthesis rates averaged $1.57 \pm 0.05$ and $1.62 \pm 0.06 \% \cdot \mathrm{d}^{-1}$ in the protein and placebo groups, respectively (Figure 8.4; $P=0.54$ ). Our findings seem to be in contrast with observations of higher muscle protein synthesis rates during recovery from a single bout of exercise when whey protein $(40,46,61)$, leucine $(13,23,38,56)$, or leucine-enriched protein (28) are ingested. The deuterated water approach applied in this study allowed the assessment of 
muscle protein synthesis rates during $7 \mathrm{~d}$ of the exercise training intervention. During this week, other factors such as regular food intake, habitual physical activity, stress, and sleep may have modulated muscle protein synthesis rates. The present findings indicate that protein supplementation does not further augment muscle protein accretion during the latter stages (week 12) of a 12-wk exercise training program in active older men.

Dietary protein intake during the intervention period was $1.2 \pm 0.1 \mathrm{~g}^{\mathrm{kg}} \mathrm{g}^{-1} \cdot \mathrm{d}^{-1}$ in the placebo group and $1.4 \pm 0.1 \mathrm{~g} \mathrm{~kg}^{-1} \cdot \mathrm{d}^{-1}$ in the protein-supplemented group. Instead of merely increasing dietary protein intake, the present study focused on timed protein supplementation, with supplements being provided immediately after exercise and before sleep. The ingestion of dietary protein in close temporal proximity to exercise has been shown to further improve post-exercise net muscle protein balance $(6,42,48,49)$. In addition, we have previously shown that the ingestion of $40 \mathrm{~g}$ casein before sleep increases overnight muscle protein synthesis rates $(16,27,43)$ and could therefore serve to promote skeletal muscle mass gains when combined with resistance exercise training $(20,50)$. In support, we have previously shown that pre-sleep protein supplementation $\left(\sim 30 \mathrm{~g}^{-\mathrm{d}^{-1}}\right)$ augments gains in muscle mass and strength after $12 \mathrm{wk}$ of resistance exercise training in healthy young men (45). In the present study, however, we failed to observe greater increases in skeletal muscle mass or strength after post-exercise and pre-sleep protein supplementation during $12 \mathrm{wk}$ of resistance exercise training in active older men. The absence of any surplus benefits of protein supplementation on muscle mass and strength gains during prolonged resistance exercise training in older compared with younger adults may be explained by age-related factors, which include a lower absolute workload, lower habitual physical activity, and the prevalence of anabolic resistance. In support, exercise workload and absolute gains in muscle mass and strength tend to be greater in younger individuals than in older individuals $(18,24,45)$. Consequently, protein supplementation appears to provide a greater benefit to the skeletal muscle adaptive response to resistance exercise training in younger individuals $(12,18,24,37,55)$.

It has been suggested that the prevalence of anabolic resistance may be compensated for by ingesting even larger amounts (i.e., $40 \mathrm{~g}$ ) of protein than what was provided in the present study (20 g whey $+1 \mathrm{~g}$ leucine). However, previous work has shown that the ingestion of 20 $\mathrm{g}$ whey should be effective at increasing post-exercise muscle protein synthesis rates in the healthy older population (60). Furthermore, numerous studies have shown leucine coingestion to further augment the muscle protein synthetic response to protein ingestion (2, $9,23,56)$. Therefore, we can only speculate on whether supplementation with a larger protein dose could have further increased muscle mass and strength gains after resistance training in these healthy, active older men.

The present findings add to the growing number of studies from our group $(30,52)$ as well as others $(10,11,14,19,22,29,34)$ that show that protein supplementation does not further augment skeletal muscle mass or strength gains during resistance exercise training in active older men who habitually consume ample amounts of dietary protein $\left(1.0-1.2 \mathrm{~g} \mathrm{~kg}^{-1} \cdot \mathrm{d}^{-1}\right)$. In 


\section{Chapter 8}

contrast, protein supplementation has been reported to increase muscle mass and strength gains during resistance exercise training in prefrail older men and women who consume less than optimal amounts of dietary protein (47). Therefore, protein supplementation may be of greater benefit in more clinically compromised older populations when gains in muscle mass, strength, or both are restricted by habitual protein consumption (4). In conclusion, protein supplementation after exercise and before sleep does not augment skeletal muscle mass or strength gains after resistance exercise training in active older men who consume ample dietary protein. 


\section{References}

1. Areta JL, Burke LM, Ross ML, Camera DM, West DWD, Broad EM, Jeacocke NA, Moore DR Stellingwerff T, Phillips SM, Hawley JA, Coffey VG. Timing and distribution of protein ingestion during prolonged recovery from resistance exercise alters myofibrillar protein synthesis. J Physiol 591: 23192331, 2013.

2. Atherton PJ, Kumar V, Selby AL, Rankin D, Hildebrandt W, Phillips BE, Williams JP, Hiscock N, Smith $\mathrm{K}$. Enriching a protein drink with leucine augments muscle protein synthesis after resistance exercise in young and older men. Clin Nutr 36: 888-895, 2017.

3. Backx EMP, Hangelbroek R, Snijders T, Verscheijden M-L, Verdijk LB, Groot LCPGM, Loon LJC Creatine Loading Does Not Preserve Muscle Mass or Strength During Leg Immobilization in Healthy, Young Males: A Randomized Controlled Trial. Sports Med 47: 1661-1671, 2017.

4. Bauer JM, Verlaan S, Bautmans I, Brandt K, Donini LM, Maggio M, McMurdo MET, Mets T, Seal C, Wijers SL, Ceda GP, De Vito G, Donders G, Drey M, Greig C, Holmbäck U, Narici M, McPhee J, Poggiogalle E, Power D, Scafoglieri A, Schultz R, Sieber CC, Cederholm T. Effects of a vitamin D and leucine-enriched whey protein nutritional supplement on measures of sarcopenia in older adults, the PROVIDE study: a randomized, double-blind, placebo-controlled trial. Journal of the American Medical Directors Association 16: 740-747, 2015.

5. Baumgartner RN, Waters DL, Gallagher D, Morley JE, Garry PJ. Predictors of skeletal muscle mass in elderly men and women. Mech Ageing Dev 107: 123-136, 1999.

6. Beelen M, Zorenc A, Pennings B, Senden JM, Kuipers H, van Loon LJC. Impact of protein coingestion on muscle protein synthesis during continuous endurance type exercise. Am J Physiol Endocrinol Metab 300: E945-E954, 2011.

7. Bemben MG, Witten MS, Carter JM, Eliot KA, Knehans AW, Bemben DA. The effects of supplementation with creatine and protein on muscle strength following a traditional resistance training program in middle-aged and older men. J Nutr Health Aging 14: 155-159, 2010.

8. Bergström J. Percutaneous needle biopsy of skeletal muscle in physiological and clinical research. Scand J Clin Lab Invest 35: 609-616, 1975.

9. Bukhari SSI, Phillips BE, Wilkinson DJ, Limb MC, Rankin D, Mitchell WK, Kobayashi H, Greenhaff PL, Smith K, Atherton PJ. Intake of low-dose leucine-rich essential amino acids stimulates muscle anabolism equivalently to bolus whey protein in older women at rest and after exercise. Am J Physiol Endocrinol Metab 308: E1056-65, 2015.

10. Campbell WW, Crim MC, Young VR, Joseph LJ, Evans WJ. Effects of resistance training and dietary protein intake on protein metabolism in older adults. Am J Physiol 268: E1143-53, 1995.

11. Candow DG, Chilibeck PD, Facci M, Abeysekara S, Zello GA. Protein supplementation before and after resistance training in older men. Eur J Appl Physiol 97: 548-556, 2006.

12. Cermak NM, Res PT, de Groot LCPGM, Saris WHM, van Loon LJC. Protein supplementation augments the adaptive response of skeletal muscle to resistance-type exercise training: a meta-analysis. Am J Clin Nutr 96: 1454-1464, 2012.

13. Dickinson JM, Gundermann DM, Walker DK, Reidy PT, Borack MS, Drummond MJ, Arora M, Volpi E, Rasmussen BB. Leucine-enriched amino acid ingestion after resistance exercise prolongs myofibrillar protein synthesis and amino acid transporter expression in older men. J Nutr 144: 1694-1702, 2014.

14. Godard MP, Williamson DL, Trappe SW. Oral amino-acid provision does not affect muscle strength or size gains in older men. Med Sci Sports Exerc 34: 1126-1131, 2002.

15. Gorissen SH, Horstman AM, Franssen R, Crombag JJ, Langer H, Bierau J, Respondek F, van Loon LJ. Ingestion of Wheat Protein Increases In Vivo Muscle Protein Synthesis Rates in Healthy Older Men in a Randomized Trial. J Nutr 146: 1651-1659, 2016.

16. Groen BBL, Res PT, Pennings B, Hertle E, Senden JMG, Saris WHM, van Loon LJC. Intragastric protein administration stimulates overnight muscle protein synthesis in elderly men. Am J Physiol Endocrinol Metab 302: E52-60, 2012.

17. Guralnik JM, Simonsick EM, Ferrucci L, Glynn RJ, Berkman LF, Blazer DG, Scherr PA, Wallace RB. A short physical performance battery assessing lower extremity function: association with self-reported disability and prediction of mortality and nursing home admission. Journal of Gerontology 49: M85-94, 1994.

18. Hartman JW, Tang JE, Wilkinson SB, Tarnopolsky MA, Lawrence RL, Fullerton AV, Phillips SM. Consumption of fat-free fluid milk after resistance exercise promotes greater lean mass accretion than 
does consumption of soy or carbohydrate in young, novice, male weightlifters. Am J Clin Nutr 86: 373 381, 2007.

19. Holm L, Olesen JL, Matsumoto K, Doi T, Mizuno M, Alsted TJ, Mackey AL, Schwarz P, Kjaer M. Proteincontaining nutrient supplementation following strength training enhances the effect on muscle mass, strength, and bone formation in postmenopausal women. J Appl Physiol 105: 274-281, 2008.

20. Holwerda AM, Kouw IW, Trommelen J, Halson SL, Wodzig WK, Verdijk LB, van Loon LJ. Physical Activity Performed in the Evening Increases the Overnight Muscle Protein Synthetic Response to Presleep Protein Ingestion in Older Men. J Nutr 146: 1307-1314, 2016.

21. Holwerda AM, Paulussen KJM, Overkamp M, Smeets JSJ, Gijsen AP, Goessens JPB, Verdijk LB, van Loon LJC. Daily resistance-type exercise stimulates overall muscle protein synthesis rates in vivo in young males. J Appl Physiol (September 21, 2017). doi: 10.1152/japplphysiol.00610.2017.

22. Iglay HB, Thyfault JP, Apolzan JW, Campbell WW. Resistance training and dietary protein: effects on glucose tolerance and contents of skeletal muscle insulin signaling proteins in older persons. Am J Clin Nutr 85: 1005-1013, 2007.

23. Katsanos CS, Kobayashi H, Sheffield-Moore M, Aarsland A, Wolfe RR. A high proportion of leucine is required for optimal stimulation of the rate of muscle protein synthesis by essential amino acids in the elderly. Am J Physiol Endocrinol Metab 291: E381-7, 2006.

24. Kerksick CM, Rasmussen CJ, Lancaster SL, Magu B, Smith P, Melton C, Greenwood M, Almada AL, Earnest CP, Kreider RB. The effects of protein and amino acid supplementation on performance and training adaptations during ten weeks of resistance training. J Strength Cond Res 20: 643-653, 2006.

25. Koopman R, Crombach N, Gijsen AP, Walrand S, Fauquant J, Kies AK, Lemosquet S, Saris WHM, Boirie $\mathbf{Y}$, van Loon LJC. Ingestion of a protein hydrolysate is accompanied by an accelerated in vivo digestion and absorption rate when compared with its intact protein. Am J Clin Nutr 90: 106-115, 2009.

26. Kosek DJ. Efficacy of 3 days/wk resistance training on myofiber hypertrophy and myogenic mechanisms in young vs. older adults. J Appl Physiol 101: 531-544, 2006.

27. Kouw IW, Holwerda AM, Trommelen J, Kramer IF, Bastiaanse J, Halson SL, Wodzig WK, Verdijk LB van Loon LJ. Protein Ingestion before Sleep Increases Overnight Muscle Protein Synthesis Rates in Healthy Older Men: A Randomized Controlled Trial. J Nutr 147: 2252-2261, 2017.

28. Kramer IF, Verdijk LB, Hamer HM, Verlaan S, Luiking YC, Kouw IWK, Senden JM, van Kranenburg J, Gijsen AP, Bierau J, Poeze M, van Loon LJC. Both basal and post-prandial muscle protein synthesis rates, following the ingestion of a leucine-enriched whey protein supplement, are not impaired in sarcopenic older males. Clinical Nutrition 36: 1440-1449, 2017.

29. Kukuljan S, Nowson CA, Sanders K, Daly RM. Effects of resistance exercise and fortified milk on skeletal muscle mass, muscle size, and functional performance in middle-aged and older men: an 18-mo randomized controlled trial. J Appl Physiol 107: 1864-1873, 2009.

30. Leenders M, Verdijk LB, van der Hoeven L, van Kranenburg J, Nilwik R, Wodzig WKWH, Senden JMG Keizer HA, van Loon LJC. Protein supplementation during resistance-type exercise training in the elderly. Med Sci Sports Exerc 45: 542-552, 2013.

31. Mamerow MM, Mettler JA, English KL, Casperson SL, Arentson-Lantz E, Sheffield-Moore M, Layman DK, Paddon-Jones D. Dietary protein distribution positively influences $24-h$ muscle protein synthesis in healthy adults. J Nutr 144: 876-880, 2014.

32. Martel GF, Roth SM, Ivey FM, Lemmer JT, Tracy BL, Hurlbut DE, Metter EJ, Hurley BF, Rogers MA. Age and sex affect human muscle fibre adaptations to heavy-resistance strength training. Experimental Physiology 91: 457-464, 2006.

33. Mayhew JL, Prinster JL, Ware JS, Zimmer DL, Arabas JR, Bemben MG. Muscular endurance repetitions to predict bench press strength in men of different training levels. J Sports Med Phys Fitness 35: 108$113,1995$.

34. Meredith CN, Frontera WR, O'Reilly KP, Evans WJ. Body composition in elderly men: effect of dietary modification during strength training. J Am Geriatr Soc 40: 155-162, 1992.

35. Mitchell WK, Williams J, Atherton P, Larvin M, Lund J, Narici M. Sarcopenia, dynapenia, and the impact of advancing age on human skeletal muscle size and strength; a quantitative review. Front Physiol 3: 260, 2012.

36. Moore DR, Robinson MJ, Fry JL, Tang JE, Glover El, Wilkinson SB, Prior T, Tarnopolsky MA, Phillips SM. Ingested protein dose response of muscle and albumin protein synthesis after resistance exercise in young men. Am J Clin Nutr 89: 161-168, 2009. 
37. Morton RW, Murphy KT, McKellar SR, Schoenfeld BJ, Henselmans M, Helms E, Aragon AA, Devries MC, Banfield L, Krieger JW, Phillips SM. A systematic review, meta-analysis and meta-regression of the effect of protein supplementation on resistance training-induced gains in muscle mass and strength in healthy adults. Br J Sports Med 52: 376-384, 2018.

38. Murphy CH, Saddler NI, Devries MC, McGlory C, Baker SK, Phillips SM. Leucine supplementation enhances integrative myofibrillar protein synthesis in free-living older men consuming lower- and higherprotein diets: a parallel-group crossover study. Am J Clin Nutr 104: 1594-1606, 2016.

39. Paddon-Jones D, Sheffield-Moore M, Katsanos CS, Zhang X-J, Wolfe RR. Differential stimulation of muscle protein synthesis in elderly humans following isocaloric ingestion of amino acids or whey protein. Exp Gerontol 41: 215-219, 2006.

40. Pennings B, Boirie Y, Senden JMG, Gijsen AP, Kuipers H, van Loon LJC. Whey protein stimulates postprandial muscle protein accretion more effectively than do casein and casein hydrolysate in older men. Am J Clin Nutr 93: 997-1005, 2011.

41. Pennings B, Groen B, de Lange A, Gijsen AP, Zorenc AH, Senden JMG, van Loon LJC. Amino acid absorption and subsequent muscle protein accretion following graded intakes of whey protein in elderly men. Am J Physiol Endocrinol Metab 302: E992-9, 2012.

42. Rasmussen BB, Tipton KD, Miller SL, Wolf SE, Wolfe RR. An oral essential amino acid-carbohydrate supplement enhances muscle protein anabolism after resistance exercise. J Appl Physiol 88: 386-392, 2000.

43. Res PT, Groen B, Pennings B, Beelen M, Wallis GA, Gijsen AP, Senden JMG, van Loon LJC. Protein ingestion before sleep improves postexercise overnight recovery. Med Sci Sports Exerc 44: 1560-1569, 2012.

44. Robinson MM, Turner SM, Hellerstein MK, Hamilton KL, Miller BF. Long-term synthesis rates of skeletal muscle DNA and protein are higher during aerobic training in older humans than in sedentary young subjects but are not altered by protein supplementation. FASEB J 25: 3240-3249, 2011.

45. Snijders T, Res PT, Smeets JSJ, van Vliet S, van Kranenburg J, Maase K, Kies AK, Verdijk LB, van Loon LJC. Protein Ingestion before Sleep Increases Muscle Mass and Strength Gains during Prolonged Resistance-Type Exercise Training in Healthy Young Men. J Nutr 145: 1178-1184, 2015.

46. Tang JE, Moore DR, Kujbida GW, Tarnopolsky MA, Phillips SM. Ingestion of whey hydrolysate, casein, or soy protein isolate: effects on mixed muscle protein synthesis at rest and following resistance exercise in young men. J Appl Physiol 107: 987-992, 2009.

47. Tieland M, Dirks ML, van der Zwaluw N, Verdijk LB, van de Rest O, de Groot LCPGM, van Loon LJC Protein supplementation increases muscle mass gain during prolonged resistance-type exercise training in frail elderly people: a randomized, double-blind, placebo-controlled trial. Journal of the American Medical Directors Association 13: 713-719, 2012.

48. Tipton KD, Elliott TA, Cree MG, Aarsland AA, Sanford AP, Wolfe RR. Stimulation of net muscle protein synthesis by whey protein ingestion before and after exercise. Am J Physiol Endocrinol Metab 292: E71E76, 2006

49. Tipton KD, Rasmussen BB, Miller SL, Wolf SE, Owens-Stovall SK, Petrini BE, Wolfe RR. Timing of amino acid-carbohydrate ingestion alters anabolic response of muscle to resistance exercise. Am J Physiol Endocrinol Metab 281: E197-206, 2001.

50. Trommelen J, Holwerda AM, Kouw IWK, Langer H, Halson SL, Rollo I, Verdijk LB, van Loon LJC. Resistance Exercise Augments Postprandial Overnight Muscle Protein Synthesis Rates. Med Sci Sports Exerc 48: 2517-2525, 2016.

51. Trommelen J, Kouw IWK, Holwerda AM, Snijders T, Halson SL, Rollo I, Verdijk LB, van Loon LJC. Presleep dietary protein-derived amino acids are incorporated in myofibrillar protein during postexercise overnight recovery. Am J Physiol Endocrinol Metab 314: E457-E467, 2018.

52. Verdijk LB, Jonkers RA, Gleeson BG, Beelen M, Meijer K, Savelberg HH, Wodzig WK, Dendale P, van Loon LJ. Protein supplementation before and after exercise does not further augment skeletal muscle hypertrophy after resistance training in elderly men. Am J Clin Nutr 89: 608-616, 2009.

53. Verdijk LB, Koopman R, Schaart G, Meijer K, Savelberg HHCM, van Loon LJC. Satellite cell content is specifically reduced in type II skeletal muscle fibers in the elderly. Am J Physiol Endocrinol Metab 292: E151-E157, 2006.

54. Vermeulen A, Verdonck L, Kaufman JM. A critical evaluation of simple methods for the estimation of free testosterone in serum. J Clin Endocrinol Metab 84: 3666-3672, 1999. 
55. Walker TB, Smith J, Herrera M, Lebegue B, Pinchak A, Fischer J. The influence of 8 weeks of wheyprotein and leucine supplementation on physical and cognitive performance. Int J Sport Nutr Exerc Metab 20: 409-417, 2010.

56. Wall BT, Hamer HM, de Lange A, Kiskini A, Groen BBL, Senden JMG, Gijsen AP, Verdijk LB, van Loon LJC. Leucine co-ingestion improves post-prandial muscle protein accretion in elderly men. Clin Nutr 32: 412-419, 2013.

57. West DW, Burd NA, Coffey VG, Baker SK, Burke LM, Hawley JA, Moore DR, Stellingwerff T, Phillips SM. Rapid aminoacidemia enhances myofibrillar protein synthesis and anabolic intramuscular signaling responses after resistance exercise. Am J Clin Nutr 94: 795-803, 2011.

58. Wilkinson DJ, Franchi MV, Brook MS, Narici MV, Williams JP, Mitchell WK, Szewczyk NJ, Greenhaff PL, Atherton PJ, Smith K. A validation of the application of D2O stable isotope tracer techniques for monitoring day-to-day changes in muscle protein subfraction synthesis in humans. Am J Physiol Endocrinol Metab 306: E571-E579, 2014.

59. Witard OC, Jackman SR, Breen L, Smith K, Selby A, Tipton KD. Myofibrillar muscle protein synthesis rates subsequent to a meal in response to increasing doses of whey protein at rest and after resistance exercise. Am J Clin Nutr 99: 86-95, 2014.

60. Yang Y, Breen L, Burd NA, Hector AJ, Churchward-Venne TA, Josse AR, Tarnopolsky MA, Phillips SM Resistance exercise enhances myofibrillar protein synthesis with graded intakes of whey protein in older men. Br J Nutr 108: 1780-1788, 2012.

61. Yang Y, Churchward-Venne TA, Burd NA, Breen L, Tarnopolsky MA, Phillips SM. Myofibrillar protein synthesis following ingestion of soy protein isolate at rest and after resistance exercise in elderly men. Nutr Metab 9: 57, 2012. 
Chapter 9

General discussion 


\section{Chapter 9}

This thesis describes a series of studies investigating the impact of physical activity and nutritional intervention strategies to promote skeletal muscle anabolism in older individuals. In this chapter, we discuss the interpretation of acute muscle protein synthetic responses and why such responses should not be considered as a reliable indicator of subsequent increases in skeletal muscle mass following more prolonged resistance-type exercise training. We follow-up by describing the potential significance of novel deuterated water methods to assess muscle protein synthesis rates over multiple days or even weeks. Next, we discuss how novel methods used to simultaneously assess fractional synthesis rates of hundreds of individual proteins may further improve our understanding of skeletal muscle reconditioning in a variety of settings. Lastly, we define future research aims to better understand the regulation of skeletal muscle mass in response to aging, nutrition, and/or exercise.

\section{Acute muscle protein synthetic responses to exercise}

In rested and fasted healthy individuals, muscle protein synthesis rates are slightly lower in comparison with muscle protein breakdown rates, which results in a negative net protein balance. A single bout of exercise robustly increases muscle protein synthesis rates $(3,10$, 35). Exercise also increases muscle protein breakdown rates, albeit to a lesser extent, which results in a more positive net muscle protein balance $(3,10,35)$. However, post-exercise net muscle protein balance will remain negative in the absence of food ingestion (3). Food ingestion, and protein ingestion in particular, further increases muscle protein synthesis rates and lowers muscle protein breakdown rates during post-exercise recovery (39). Consequently, food ingestion after exercise allows net muscle protein balance to become positive. This positive net muscle protein balance allows muscle protein accretion over the course of a prolonged exercise training period. As such, both exercise and nutrition are required to promote skeletal muscle hypertrophy over time.

The relationship between the acute post-exercise increase in muscle protein synthesis rates and subsequent skeletal muscle hypertrophy has led some to believe that post-exercise muscle protein synthesis rates can serve as an indicator to predict long-term gains in skeletal muscle mass. Recent studies have directly assessed the relationship between acute postexercise muscle protein synthetic responses and gains in skeletal muscle mass following more prolonged resistance-type exercise training within the same individuals. These studies have demonstrated no significant correlations between the magnitude of the muscle protein synthetic response to the first bout of resistance-type exercise and the subsequent gains in skeletal muscle mass following more prolonged resistance-type exercise training (21, 24). Obviously, the acute post-exercise muscle protein synthetic response to a single bout of exercise does not provide a proper indication of skeletal muscle mass that may be gained following more prolonged resistance-type exercise training. 
There are obvious reasons why the acute post-exercise increase in muscle protein synthesis rates should not be considered as a reliable indicator of subsequent increases in skeletal muscle mass following more prolonged resistance-type exercise training. First of all, the post-exercise increase in muscle protein synthesis rates is not exclusively dedicated to support myofibrillar protein accretion. Instead, a large fraction of the post-exercise increase in muscle protein synthesis rates is likely directed towards restoring energy homeostasis, repairing contraction-induced damage, and supporting tissue (re)conditioning in response to the type of exercise performed. The latter is evident when comparing the muscle adaptive response to resistance-type exercise training with that of endurance-type exercise training (Table 9.1). A single bout of endurance- or resistance-type exercise both result in a 60-70\% increase in mixed muscle protein synthesis rates during acute post-exercise recovery $(10,21$, 36). Although both types of exercise increase muscle protein synthesis rates, the characteristic physiological adaptations are caused, in part, by differences in the postexercise stimulation of sub-cellular muscle protein fractions (i.e., myofibrillar, mitochondrial, and/or collagen). In particular, a bout of resistance-type exercise mainly increases myofibrillar protein synthesis rates (57), which contributes to skeletal muscle hypertrophy over a more prolonged period of resistance-type exercise training (43). On the other hand, a bout of endurance-type exercise primarily increases mitochondrial protein synthesis rates (57), which contributes to the increase in skeletal muscle mitochondrial content and the corresponding increase in whole-body oxidative capacity following a more prolonged period of endurance-type exercise training (43). It is therefore evident that while the post-exercise increase in mixed muscle protein synthesis rates may indeed support skeletal muscle hypertrophy, it also contributes to the broader (re)conditioning of skeletal muscle tissue in response to the specific type of exercise performed. 
Table 9.1 The acute and long-term adaptive responses to endurance- and resistance-type exercise

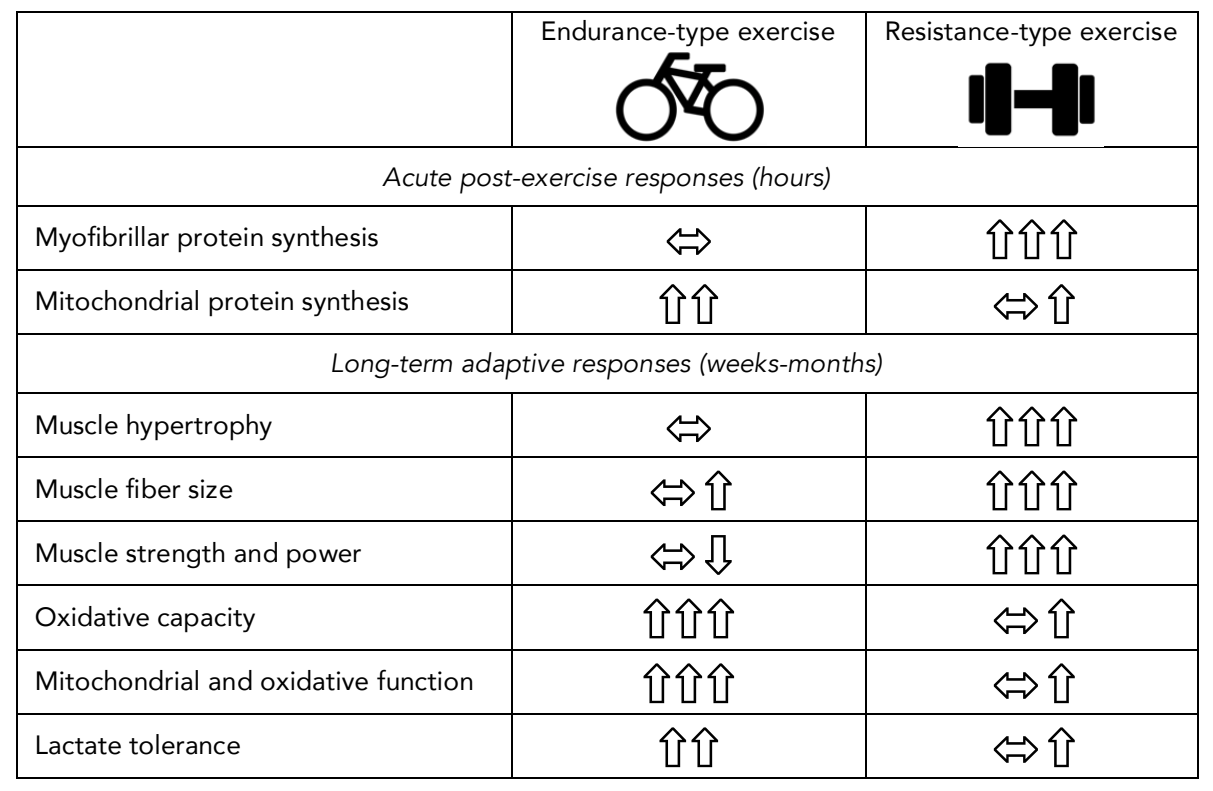

${ }^{1}$ Endurance-type exercise generally encompasses longer exercise durations ranging from several minutes to several hours at various exercise intensities involving repetitive, low-resistance muscle contractions. Some key examples of endurance-type exercise include running, cycling, and swimming. Resistance-type exercise generally encompasses exercise bouts of shorter duration involving relatively few high-to-maximal resistance muscle contractions. Some key examples of resistance-type exercise include weight lifting and body building. $\widehat{\imath}$, values increase; $\sqrt{3}$, values decrease; $\Leftrightarrow$, values remain unchanged; $\hat{\imath}$ or $\Omega$, small effect; $\hat{\imath} \hat{\imath}$ or $\Omega \Omega$, medium effect; $\hat{\imath} \hat{\imath} \hat{u}$ or $\Omega \Omega \Omega$, large effect; $\Leftrightarrow \hat{\imath}$ or $\Leftrightarrow \Omega$, no change or slight change. Adapted from Egan and Zierath (14).

Another reason why a single, acute muscle protein synthetic response cannot be predictive of long-term skeletal muscle mass gains is that the post-exercise increase in muscle protein synthesis rates can be modulated by several factors. For example, successive exercise bouts over the course of a resistance-type exercise training program will result in a more immediate, yet overall diminished increase in post-exercise muscle protein synthesis rates $(10,35,51)$. Furthermore, several other parameters related to training, such as contraction type (27), intensity $(8,25)$, volume load $(7,18)$, time under tension (5), and inter-set rest (23), have been shown to modulate the post-exercise increase in muscle protein synthesis rates. Aside from training parameters, the properties of food ingestion during post-exercise recovery also seem to impact the overall increase in (daily) muscle protein synthesis rates. In particular, the amount $(28,33,59,61,62)$, type $(32,50)$ and source $(50,58,62)$ of dietary protein ingested in a single meal modulates post-exercise muscle protein synthesis rates. In the present thesis, we also describe the impact of the amount (Chapter 2) and amino acid composition (Chapter 3 ) of ingested protein on post-exercise muscle protein synthesis rates in older men. Other than single meal responses, post-exercise muscle protein synthesis rates are also impacted by timing $(1,19,42,53)$ and distribution $(1,20)$ of meals ingested throughout the day. Lastly, there are several secondary factors present in real-life settings, such as sleep-wake patterns, diurnal fluctuations in circulating hormones, stress, and illness, which may also impact the post-exercise increase in muscle protein synthesis rates. 
The application of acute labeled amino acid infusion methods has been critical in determining the impact of these various individual factors on muscle protein synthesis rates. Considering that the presence of any combination of these factors may change over a prolonged resistance-type training program, it is evident why acute post-exercise muscle protein synthesis rates should not be considered as a reliable indicator of long-term gains in skeletal muscle mass following prolonged exercise training. Clearly, we can improve our understanding of skeletal muscle mass regulation by capturing the interaction of the various factors known to impact muscle protein synthesis rates. With such an approach, we can better define the anabolic impact of intervention strategies (e.g., exercise and nutrition) against the presence of more habitual factors (e.g., habitual physical activity and regular dietary intake) that are known to modulate muscle protein synthesis rates.

To capture the presence of habitual factors, the duration of a tracer infusion protocol would need to be extended from hours to several days or even weeks. However, infusing amino acid tracers for a period longer than $12 \mathrm{~h}$ likely introduces considerable error into the assessment due to labeled amino acid tracer recycling $(48,54)$. Furthermore, the application of amino acid tracer infusion methodologies requires stationary infusion pumps and intravenous infusion lines. The use of such equipment restricts the assessment of muscle protein synthesis rates to volunteers who must remain in a well-controlled laboratory setting. Therefore, there is a need for novel methods to assess muscle protein synthesis rates in freeliving conditions over more prolonged periods.

\section{Assessment of muscle protein synthesis rates over a more prolonged period}

Deuterated water $\left({ }^{2} \mathrm{H}_{2} \mathrm{O}\right)$ ingestion has been applied as early as 1935 for the study of in vivo substrate metabolism (47). Deuterated water ingestion increases body water deuterium $\left({ }^{2} \mathrm{H}\right)$ enrichment, which is subsequently incorporated into numerous de novo synthesized metabolites. Deuterium is also incorporated into most non-essential amino acids, which can be isolated and analyzed to assess protein metabolism. Notably, the non-essential amino acid alanine becomes rapidly (i.e., $<2$ h) and highly (i.e., 3.7-fold that of body water enrichment) labeled with deuterium (Chapter 7). As such, alanine serves as one of the most convenient individual amino acids to use as a tracer for assessing muscle protein synthesis rates when applying the deuterated water method. The de novo labeling properties of alanine coupled with the long half-life of the body water pool (i.e., 10-14 days) permits long assessment periods (i.e., days-to-weeks) without the need for stationary infusion equipment. In other words, test subjects in these metabolic studies serve as their own renewable source of labeled amino acid tracer. Subjects can resume normal daily activity during the experimental protocol and the impact of all anabolic stimuli, including a study intervention, is captured within the longer assessment of muscle protein synthesis rates.

Impact of physical activity on daily muscle protein synthesis rates 
The application of the deuterated water method to detect changes in muscle protein synthesis rates in vivo in humans was first demonstrated by Robinson et al in 2011. In this study, it was demonstrated that muscle protein synthesis rates were higher in older adults performing 6 weeks of endurance-type exercise training when compared to younger adults who did not perform any regular exercise (44). Since then, deuterated water methods have been applied to demonstrate the impact of an increased level of physical activity, including a variety of resistance- and endurance-type exercise interventions on daily muscle protein synthesis rates $(2,4,12,46,56)$.

In Chapter 7, we applied the deuterated water method to demonstrate that daily resistancetype exercise in one leg increases local muscle protein synthesis rates when compared to the contra-lateral, non-exercised leg. We found that the absolute muscle protein synthetic response to 3 days of resistance-type exercise $\left(0.08 \% \cdot h^{-1}\right)$ aligns very well with findings from acute tracer infusion studies $\left(0.08-0.10 \% \cdot h^{-1}\right)(6,11,17,34,40,41,59,60)$. Interestingly, our observation of $\sim 25 \%$ greater muscle protein synthesis rates in the exercise versus control leg is lower than similar comparisons assessed using acute labeled amino acid infusion protocols, which typically show $30-100 \%$ greater muscle protein synthesis rates following a bout of resistance-type exercise. The difference can be explained by a greater absolute muscle protein synthesis rate observed in our deuterated water assessment of the nonexercised, control leg $\left(0.06 \% \cdot h^{-1}\right)$ when compared to basal conditions assessed using acute tracer infusion methods $\left(0.02-0.04 \% \cdot h^{-1}\right)(6,7,15,29)$. The greater absolute muscle protein synthesis rates measured using the deuterated water method reflect the surplus anabolic impact of habitual physical activity, diet, sleep-wake patterns, and/or hormonal patterns captured throughout the 3-day assessment in both the exercised and non-exercised, control leg. 


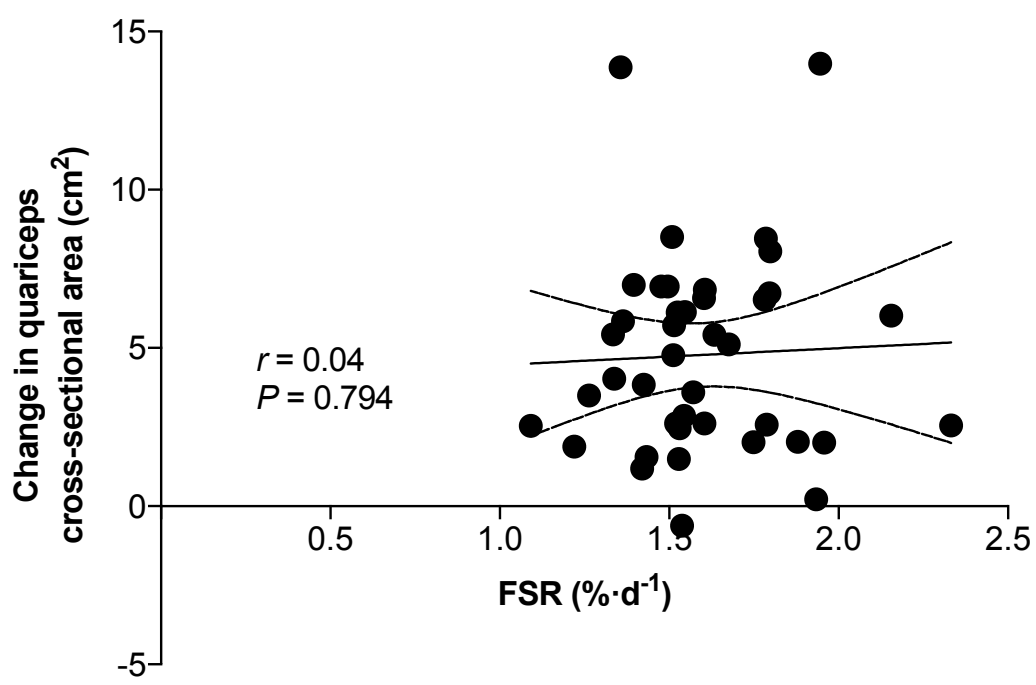

Figure 9.1 Correlation between the change in quadriceps cross-sectional area $\left(\mathrm{cm}^{2}\right)$ following 12 weeks of resistance-type exercise training and myofibrillar protein fractional synthetic rate $\left(F S R, \% \cdot d^{-1}\right)$ during week 12 of the resistance-type exercise training program $(n=41)$. The solid line indicates the linear regression line of best fit and the dashed lines represent the $95 \%$ confidence interval. No correlation was observed $(r=0.04 ; P=$ 0.794).

The application of deuterated water to measure muscle protein synthesis rates over daysto-weeks more completely reflects the impact of factors that may contribute to muscle mass gains during more prolonged resistance-type exercise training. Therefore, the application of the deuterated water method within a long-term intervention study should provide better insight into muscle protein synthetic responses underlying the skeletal muscle adaptive responses to a long-term exercise intervention. In Chapter 8 of this dissertation, we measured the change in skeletal muscle mass in response to placebo or protein supplementation during 12 weeks of resistance-type exercise training in healthy older men. We also administered deuterated water to all volunteers during the last week of the exercise training program to measure daily myofibrillar protein synthesis rates. We observed good agreement between our assessments of myofibrillar protein synthesis rates over the 7-day period and the various measures of training-induced skeletal muscle mass gain between the protein and placebo groups. However, on an individual basis, we did not detect a significant correlation between muscle protein synthesis rates and the increase in skeletal muscle mass assessed using computed tomography (CT) scans of the upper thigh (Figure 9.1). These data likely reflect the fact that the muscle adaptive response (i.e., hypertrophic response) to resistance-type exercise training is highly dynamic throughout a period of training and that the muscle anabolic response may predominantly occur during an earlier phase of training. It may therefore be speculated that daily myofibrillar protein synthesis rates during the initial phase of a resistance-type exercise training program would correlate stronger with changes in skeletal muscle mass during the same period. A recent study showed that muscle protein synthesis rates assessed using the deuterated water method over the first 3 weeks of 
resistance-type exercise training correlate well with thigh muscle thickness measured following the same period of training (4). While these data do not necessarily demonstrate that muscle protein synthesis rates align with the training-induced change in muscle thickness, the investigators also show in younger adults that the initial rise in muscle protein synthesis rates return to near baseline levels in the latter stages (weeks 3-6) of the training program (4). This dynamic nature of the muscle adaptive response throughout prolonged exercise training was also demonstrated in recent work that applied the deuterated water method to measure muscle protein synthesis rates during separate 3-day intervals at different phases of a 10 -week resistance-type exercise training program. This study demonstrated that muscle protein synthesis rates correlated well with training-induced changes in skeletal muscle mass only after the initial contraction-induced muscle damage responses had subsided (12). Altogether, the application of deuterated water within longterm intervention studies is beginning to improve our understanding of the dynamic regulation of muscle protein synthesis rates that underlie skeletal muscle mass gain over the course of an exercise training program.

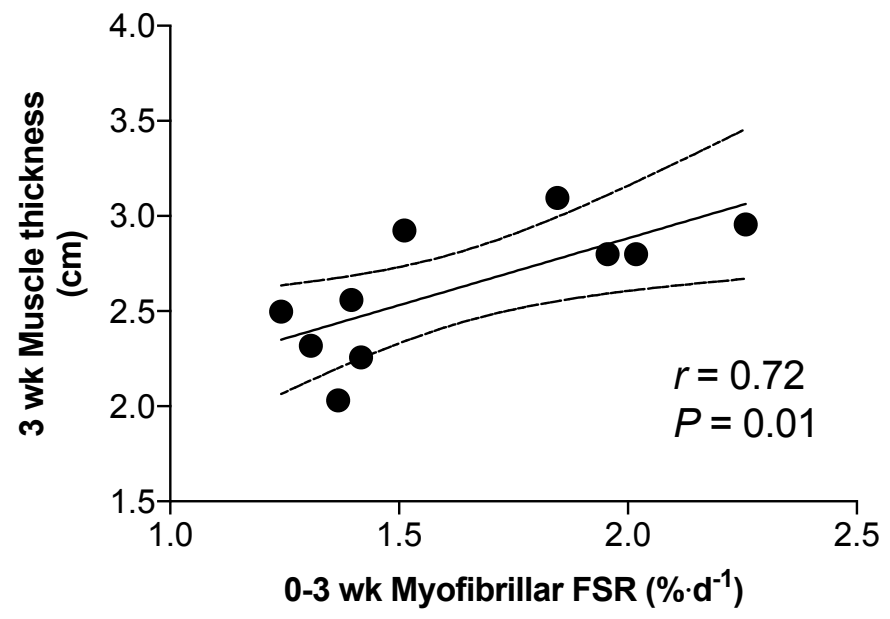

Figure 9.2 Correlation between thigh muscle thickness $(\mathrm{cm})$ following 3 weeks of resistance-type exercise and myofibrillar protein fractional synthetic rate $\left(F S R, \% \cdot d^{-1}\right)$ during weeks $0-3$ of the resistance-type exercise training program $(n=10)$. The lines indicate the linear regression line of best fit and the $95 \%$ confidence interval. A significant positive correlation was observed $(r=0.72$; $P=0.01)$. Figure adapted from Brook et al. (4).

Along with studies investigating the underlying regulation of skeletal muscle hypertrophy, recent work has demonstrated that the deuterated water method can also be effectively applied to investigate the underlying regulation of skeletal muscle atrophy. In particular, recent studies have applied the deuterated water method to demonstrate decreases in muscle protein synthesis rates during short periods of reduced physical activity, such as step reduction (22) and limb immobilization (26). However, it remains to be determined how disruptions in daily muscle protein synthesis rates underlie skeletal muscle atrophy during decreased physical activity, aging, and disease. Studies on these topics are currently 
underway within our own research group as well as in collaboration with the University of Exeter and the University of Birmingham.

\section{Assessment of fractional protein synthesis rates of individual proteins}

Over the last few decades, investigators have gained insight into muscle protein reconditioning responses by applying amino acid tracers and performing separation techniques on muscle tissue samples to attain concentrated sub-cellular protein fractions (i.e., myofibrillar and mitochondrial). Isotope analysis on the separate fractions has revealed that mitochondrial proteins generally synthesize at a faster rate (i.e., 0.06-0.20 \%.d-1) when compared to myofibrillar proteins (i.e., $\left.0.02-0.08 \% \cdot d^{-1}\right)(5,13,45)$. While this approach has revealed clear differences in average protein synthesis rates between the sub-cellular muscle protein fractions, each sub-cellular fraction consists of numerous individual proteins. Therefore, isolated anabolic responses of individual proteins, subsets of proteins, or protein networks, may be masked by the responses of other, more abundant proteins residing within the same protein fraction. One solution has been to apply western blotting techniques to semi-quantitatively assess changes in the abundance of key individual muscle proteins. However, while this approach provides some evidence of mechanisms underlying skeletal muscle tissue adaptation, the coordinated reconditioning of hundreds or thousands of different proteins, not only within the same sub-cellular protein fraction, but also across the entire muscle proteome, are required to promote physiological adaptation. Therefore, our understanding of the overall coordination of muscle proteomic responses to a variety of situations and interventions remains unclear.

Deuterated water ingestion combined with recent developments in high-throughput analytical techniques (e.g., LC-MS/MS instrumentation) allows for simultaneous in vivo assessment of the fractional synthesis rates of hundreds of individual proteins. The endogenous deuterium labeling of nearly all amino acids dramatically increases overall deuterium incorporation into newly synthesized peptides, which are assembled into distinct skeletal muscle proteins. Rapid detection and identification of peptides using LC-MS/MS analysis allows quantitation of the increase in peptide deuterium enrichment over time and subsequent estimation of fractional synthesis rates of the corresponding individual proteins. This approach was first applied to study proteome dynamics in rat brain tissue (37) and later modified to determine plasma proteome dynamics in vivo in humans (38). Within the last couple of years, dynamic proteomic approaches have been applied in human skeletal muscle tissue to assess in vivo proteome synthetic responses to exercise interventions and energy intake restriction $(9,30,49)$.

In a recent pilot study, we compared one group of rats that were provided with a running wheel in their cage (PA, $n=3$ ) with a separate group of rats that remained sedentary (Rest, $n=3$ ) over 21 days. By providing deuterated water and collecting muscle tissue, we were able to measure and compare the synthesis rates of 106 different proteins in the soleus 


\section{Chapter 9}

muscle. Physical activity impacted the synthesis rates of 83 proteins overall, with a percentage change of myofibrillar and mitochondrial proteins ranging from $-26 \%$ to $+95 \%$ when expressed relative to the control group. In particular, we found that key mitochondrial proteins, such as cytochrome-C oxidase $\left(1.83 \% \cdot d^{-1}\right)$ and citrate synthase $\left(2.36 \% \cdot d^{-1}\right)$, demonstrated greater synthesis rates when compared to key myofibrillar proteins, such as $\alpha$-actin $\left(0.27 \% \cdot d^{-1}\right)$ and myosin light chain-3 $\left(0.65 \% \cdot d^{-1}\right.$, Figure 9.3$)$. The relative difference between proteins is directly in line with previous literature, demonstrating that citrate synthase and cytochrome-C-oxidase synthesis rates are approximately 5 -fold greater when compared to actin and myosin (16). Wheel running stimulated greater synthesis rates of citrate synthase, but not cytochrome-C oxidase, $\alpha$-actin or myosin light chain- 3 synthesis rates (Figure 9.3). Citrate synthase abundance and activity are important determinants of peak oxidative capacity and have been shown to increase in response to prolonged endurance-type exercise training. Our preliminary work indicates the that proteome dynamic approaches can be applied to attain a more detailed characterization of the muscle proteomic synthetic response to physical activity interventions.

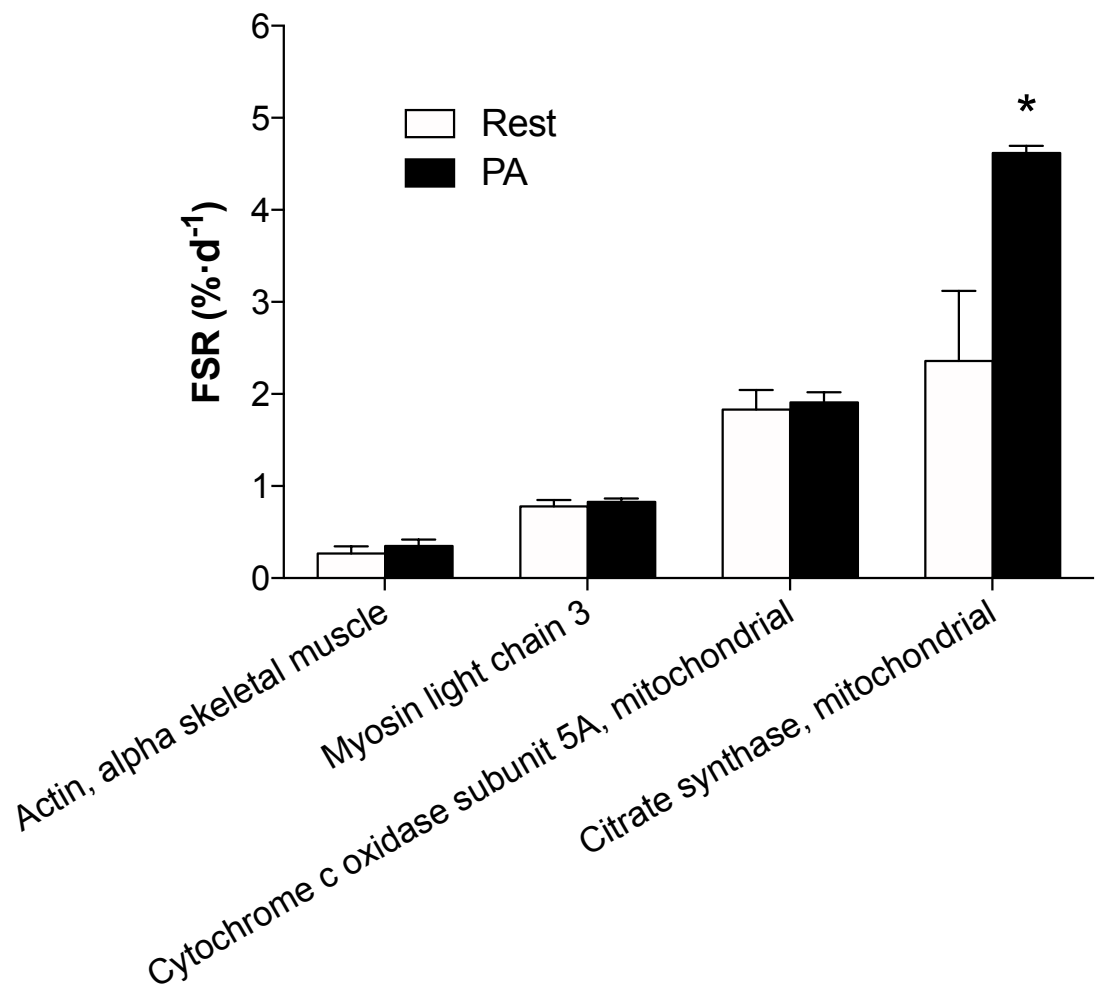

Figure 9.3 Fractional synthesis rates (FSR; \% $d^{-1}$ ) of four individual proteins measured in rodent soleus muscle. Values represent means + SEM. Data were taken from a larger data set including 123 individual proteins. Rodents from the physical activity group (PA) had access to a running wheel and rodents from the rest group (Rest) did not ( $n=3 /$ group). Analyzed with a Student's unpaired t-test . ${ }^{*}$ Significantly different from Rest $(P<$ 0.01). 
Aging is associated with specific type II muscle fiber atrophy $(31,55)$. In Chapter $\mathbf{8}$, we observed that resistance-type exercise training increases type II, but not type I, muscle fiber cross-sectional area in older men. These findings are one indication that the different fibertypes can exhibit distinct adaptive responses to an exercise intervention. Therefore, better characterization of protein synthetic responses specific to each muscle fiber-type would provide better insight into the impact of aging or different intervention strategies, such as resistance-type exercise training, on fiber-type specific reconditioning. Current isotopebased measurements provide us with the combined protein synthetic response in all fibertypes contained in a muscle tissue sample. To perform fiber-type specific measurements, sampled muscle fibers would need to be sorted prior to protein extraction and subsequent determination of isotopic enrichment. However, whereas manual or semi-automatic muscle fiber sorting is technically possible, it is seldom performed due to technical challenges and laborious nature of the technique. One solution would be to apply a proteome dynamic approach in a sample of mixed fiber-types to target and compare the synthetic responses of key fiber-type specific proteins. For example, targeted analysis of the major protein isoforms, such as myosin heavy chain I ( $\mathrm{MHCl}$ ) for the type I muscle fibers and myosin heavy chain II (MHCII) for the type II muscle fibers, may provide us with a better understanding of the myofibrillar protein synthetic responses of the different fiber-types. In fact, recent work has applied the proteome dynamics approach in obese individuals who performed unilateral exercise and reported that the synthesis rate of the MHClla isoform was greater in the leg preforming resistance-type exercise when compared to the contralateral control leg (9). Along with the measurement of peptide deuterium enrichment, recent developments have been made to simultaneously assess individual peptide abundances. Attaining data on protein synthesis rate and changes in peptide abundance over time allows for an estimation of the breakdown rates of individual muscle proteins (9). Combined assessments of muscle protein synthesis and muscle protein breakdown rates provide the most complete evaluation of muscle protein metabolic responses to a study intervention. However, the assessment of muscle protein breakdown rates has been challenging to perform, especially under conditions involving dietary protein ingestion (52). Therefore, the proteome dynamics approach represents an important methodological development in the field of human muscle protein metabolism as future application will provide more complete insight into the dynamic regulation of muscle protein reconditioning. Overall, knowledge attained from proteome dynamics applications will be essential for developing our understanding of muscle mass regulation in response to aging, disuse and disease and will be applied to develop more effective intervention strategies in the near future. 


\section{Chapter 9}

\section{Future directions}

The studies described in this thesis extend on our understanding of the regulation of skeletal muscle tissue maintenance in older individuals. Though we have made progress by identifying interactions between physical activity and food intake, many gaps in our knowledge remain. As described above, novel applications of the deuterated water methodology will be applied in future research to improve our understanding of long-term muscle protein synthetic responses in a variety of settings. This approach allows us to address some interesting questions that need to be answered in future research and include the following:

1. How do different levels of habitual physical activity impact day-to-day muscle protein synthesis rates in healthy individuals? How are daily muscle protein synthesis rates impacted by sedentary behavior? Are changes in daily protein synthesis rates due to lifestyle modification different between healthy young and older individuals?

2. What is the minimum amount of physical activity needed during short periods of muscle disuse (i.e., injury, illness or hospitalization) to compensate for disturbances in muscle protein synthesis rates?

3. Can changes in dietary protein intake patterns (i.e., daily amount, source, meal distribution) impact daily muscle protein synthesis rates in healthy individuals and more clinically compromised sub-populations?

4. How are individual muscle protein synthesis rates impacted by nutrition or different types of exercise? In which individual proteins (or protein networks) are synthesis rates increased or decreased? Are increases in protein synthesis rates accompanied by greater protein abundances and/or activity? By applying a proteomic approach, can major proteins that drive phenotypic or functional adaptation be identified as "rate-limiting" and targeted to develop more effective intervention strategies to combat age-related muscle mass and strength loss?

5. Can the assessment of daily protein synthesis rates of fiber-type specific proteins or isoforms of proteins be used to study fiber-type specific adaptive responses to aging, disuse and various intervention strategies? 


\section{References}

1. Areta JL, Burke LM, Ross ML, Camera DM, West DWD, Broad EM, Jeacocke NA, Moore DR, Stellingwerff T, Phillips SM, Hawley JA, Coffey VG. Timing and distribution of protein ingestion during prolonged recovery from resistance exercise alters myofibrillar protein synthesis. J Physiol 591: 23192331, 2013.

2. Bell KE, Séguin C, Parise G, Baker SK, Phillips SM. Day-to-Day Changes in Muscle Protein Synthesis in Recovery From Resistance, Aerobic, and High-Intensity Interval Exercise in Older Men. J Gerontol A Biol Sci Med Sci 70: 1024-1029, 2015.

3. Biolo G, Maggi SP, Williams BD, Tipton KD, Wolfe RR. Increased rates of muscle protein turnover and amino acid transport after resistance exercise in humans. Am J Physiol 268: E514-20, 1995.

4. Brook MS, Wilkinson DJ, Mitchell WK, Lund JN, Szewczyk NJ, Greenhaff PL, Smith K, Atherton PJ. Skeletal muscle hypertrophy adaptations predominate in the early stages of resistance exercise training, matching deuterium oxide-derived measures of muscle protein synthesis and mechanistic target of rapamycin complex 1 signaling. FASEB J 29: 4485-4496, 2015.

5. Burd NA, Andrews RJ, West DWD, Little JP, Cochran AJR, Hector AJ, Cashaback JGA, Gibala MJ Potvin JR, Baker SK, Phillips SM. Muscle time under tension during resistance exercise stimulates differential muscle protein sub-fractional synthetic responses in men. J Physiol 590: 351-362, 2012.

6. Burd NA, Gorissen SH, van Vliet S, Snijders T, van Loon LJ. Differences in postprandial protein handling after beef compared with milk ingestion during postexercise recovery: a randomized controlled trial. Am J Clin Nutr 102: 828-836, 2015.

7. Burd NA, Holwerda AM, Selby KC, West DWD, Staples AW, Cain NE, Cashaback JGA, Potvin JR Baker SK, Phillips SM. Resistance exercise volume affects myofibrillar protein synthesis and anabolic signalling molecule phosphorylation in young men. J Physiol 588: 3119-3130, 2010.

8. Burd NA, West DWD, Staples AW, Atherton PJ, Baker JM, Moore DR, Holwerda AM, Parise G, Rennie MJ, Baker SK, Phillips SM. Low-Load High Volume Resistance Exercise Stimulates Muscle Protein Synthesis More Than High-Load Low Volume Resistance Exercise in Young Men. PLoS ONE 5: e1203310, 2010.

9. Camera DM, Burniston JG, Pogson MA, Smiles WJ, Hawley JA. Dynamic proteome profiling of individual proteins in human skeletal muscle after a high-fat diet and resistance exercise. FASEB J 31: 5478-5494, 2017.

10. Chesley A, MacDougall JD, Tarnopolsky MA, Atkinson SA, Smith K. Changes in human muscle protein synthesis after resistance exercise. J Appl Physiol 73: 1383-1388, 1992.

11. Churchward-Venne TA, Breen L, Di Donato DM, Hector AJ, Mitchell CJ, Moore DR, Stellingwerff T, Breuille D, Offord EA, Baker SK, Phillips SM. Leucine supplementation of a low-protein mixed macronutrient beverage enhances myofibrillar protein synthesis in young men: a double-blind, randomized trial. Am J Clin Nutr 99: 276-286, 2014.

12. Damas F, Phillips SM, Libardi CA, Vechin FC, Lixandrão ME, Jannig PR, Costa LAR, Bacurau AV Snijders T, Parise G, Tricoli V, Roschel H, Ugrinowitsch C. Resistance training-induced changes in integrated myofibrillar protein synthesis are related to hypertrophy only after attenuation of muscle damage. J Physiol 594: 5209-5222, 2016.

13. Donges CE, Burd NA, Duffield R, Smith GC, West DWD, Short MJ, Mackenzie R, Plank LD, Shepherd PR, Phillips SM, Edge JA. Concurrent resistance and aerobic exercise stimulates both myofibrillar and mitochondrial protein synthesis in sedentary middle-aged men. J Appl Physiol 112: 1992-2001, 2012.

14. Egan B, Zierath JR. Exercise Metabolism and the Molecular Regulation of Skeletal Muscle Adaptation. Cell Metab 17: 162-184, 2013.

15. Gorissen SHM, Burd NA, Hamer HM, Gijsen AP, Groen BB, van Loon LJC. Carbohydrate coingestion delays dietary protein digestion and absorption but does not modulate postprandial muscle protein accretion. J Clin Endocrinol Metab 99: 2250-2258, 2014.

16. Jaleel A, Short KR, Asmann YW, Klaus KA, Morse DM, Ford GC, Nair KS. In vivo measurement of synthesis rate of individual skeletal muscle mitochondrial proteins. Am J Physiol Endocrinol Metab 295: E1255-E1268, 2008.

17. Koopman R, Verdijk L, Manders RJF, Gijsen AP, Gorselink M, Pijpers E, Wagenmakers AJM, van Loon LJC. Co-ingestion of protein and leucine stimulates muscle protein synthesis rates to the same extent in young and elderly lean men. Am J Clin Nutr 84: 623-632, 2006. 
18. Kumar V, Selby A, Rankin D, Patel R, Atherton P, Hildebrandt W, Williams J, Smith K, Seynnes O, Hiscock N, Rennie MJ. Age-related differences in the dose-response relationship of muscle protein synthesis to resistance exercise in young and old men. J Physiol 587: 211-217, 2009.

19. Levenhagen DK, Gresham JD, Carlson MG, Maron DJ, Borel MJ, Flakoll PJ. Postexercise nutrient intake timing in humans is critical to recovery of leg glucose and protein homeostasis. Am J Physiol Endocrinol Metab 280: E982-93, 2001.

20. Mamerow MM, Mettler JA, English KL, Casperson SL, Arentson-Lantz E, Sheffield-Moore M, Layman DK, Paddon-Jones D. Dietary protein distribution positively influences 24-h muscle protein synthesis in healthy adults. J Nutr 144: 876-880, 2014.

21. Mayhew DL, Kim J-S, Cross JM, Ferrando AA, Bamman MM. Translational signaling responses preceding resistance training-mediated myofiber hypertrophy in young and old humans. J Appl Physiol 107: 1655-1662, 2009.

22. McGlory C, Allmen von MT, Stokes T, Morton RW, Hector AJ, Lago BA, Raphenya AR, Smith BK, McArthur AG, Steinberg GR, Baker SK, Phillips SM. Failed Recovery of Glycemic Control and Myofibrillar Protein Synthesis With 2 wk of Physical Inactivity in Overweight, Prediabetic Older Adults. The Journals of Gerontology: Series A 2012: 320482-8, 2017.

23. McKendry J, Pérez-López A, McLeod M, Luo D, Dent JR, Smeuninx B, Yu J, Taylor AE, Philp A, Breen L. Short inter-set rest blunts resistance exercise-induced increases in myofibrillar protein synthesis and intracellular signalling in young males. Experimental Physiology 101: 866-882, 2016.

24. Mitchell CJ, Churchward-Venne TA, Parise G, Bellamy L, Baker SK, Smith K, Atherton PJ, Phillips SM. Acute Post-Exercise Myofibrillar Protein Synthesis Is Not Correlated with Resistance Training-Induced Muscle Hypertrophy in Young Men. PLoS ONE 9: e89431-7, 2014.

25. Mitchell CJ, Churchward-Venne TA, West DWD, Burd NA, Breen L, Baker SK, Phillips SM. Resistance exercise load does not determine training-mediated hypertrophic gains in young men. J Appl Physiol 113: 71-77, 2012.

26. Mitchell CJ, D'Souza RF, Mitchell SM, Figueiredo VC, Miller BF, Hamilton KL, Peelor FF, Coronet M, Pileggi CA, Durainayagam B, Fanning AC, Poppitt SD, Cameron-Smith D. Impact of dairy protein during limb immobilization and recovery on muscle size and protein synthesis; a randomized controlled trial. J Appl Physiol 124: 717-728, 2018.

27. Moore DR, Phillips SM, Babraj JA, Smith K, Rennie MJ. Myofibrillar and collagen protein synthesis in human skeletal muscle in young men after maximal shortening and lengthening contractions. Am J Physiol Endocrinol Metab 288: E1153-9, 2005.

28. Moore DR, Robinson MJ, Fry JL, Tang JE, Glover El, Wilkinson SB, Prior T, Tarnopolsky MA, Phillips SM. Ingested protein dose response of muscle and albumin protein synthesis after resistance exercise in young men. Am J Clin Nutr 89: 161-168, 2009.

29. Moore DR, Tang JE, Burd NA, Rerecich T, Tarnopolsky MA, Phillips SM. Differential stimulation of myofibrillar and sarcoplasmic protein synthesis with protein ingestion at rest and after resistance exercise. J Physiol 587: 897-904, 2009.

30. Murphy $\mathrm{CH}$, Shankaran M, Churchward-Venne TA, Mitchell CJ, Kolar NM, Burke LM, Hawley JA, Kassis A, Karagounis LG, Li K, King C, Hellerstein M, Phillips SM. Effect of resistance training and protein intake pattern on myofibrillar protein synthesis and proteome kinetics in older men in energy restriction. J Physiol 596: 2091-2120, 2018.

31. Nilwik R, Snijders T, Leenders M, Groen BBL, van Kranenburg J, Verdijk LB, van Loon LJC. The decline in skeletal muscle mass with aging is mainly attributed to a reduction in type II muscle fiber size. Exp Gerontol 48: 492-498, 2013.

32. Pennings B, Boirie Y, Senden JMG, Gijsen AP, Kuipers H, van Loon LJC. Whey protein stimulates postprandial muscle protein accretion more effectively than do casein and casein hydrolysate in older men. Am J Clin Nutr 93: 997-1005, 2011.

33. Pennings B, Groen B, de Lange A, Gijsen AP, Zorenc AH, Senden JMG, van Loon LJC. Amino acid absorption and subsequent muscle protein accretion following graded intakes of whey protein in elderly men. Am J Physiol Endocrinol Metab 302: E992-9, 2012.

34. Pennings B, Koopman R, Beelen M, Senden JMG, Saris WHM, van Loon LJC. Exercising before protein intake allows for greater use of dietary protein-derived amino acids for de novo muscle protein synthesis in both young and elderly men. Am J Clin Nutr 93: 322-331, 2011.

35. Phillips SM, Tipton KD, Aarsland A, Wolf SE, Wolfe RR. Mixed muscle protein synthesis and breakdown after resistance exercise in humans. Am J Physiol 273: E99-107, 1997. 
36. Phillips SM, Tipton KD, Aarsland A, Wolf SE, Wolfe RR. Mixed muscle protein synthesis and breakdown after resistance exercise in humans. Am J Physiol 273: E99-107, 1997.

37. Price JC, Guan S, Burlingame A, Prusiner SB, Ghaemmaghami S. Analysis of proteome dynamics in the mouse brain. Proc Natl Acad Sci USA 107: 14508-14513, 2010.

38. Price JC, Holmes WE, Li KW, Floreani NA, Neese RA, Turner SM, Hellerstein MK. Measurement of human plasma proteome dynamics with $2 \mathrm{H} 2 \mathrm{O}$ and liquid chromatography tandem mass spectrometry. Analytical Biochemistry 420: 73-83, 2012.

39. Rasmussen BB, Tipton KD, Miller SL, Wolf SE, Wolfe RR. An oral essential amino acid-carbohydrate supplement enhances muscle protein anabolism after resistance exercise. J Appl Physiol 88: 386-392, 2000.

40. Reidy PT, Walker DK, Dickinson JM, Gundermann DM, Drummond MJ, Timmerman KL, Fry CS, Borack MS, Cope MB, Mukherjea R, Jennings K, Volpi E, Rasmussen BB. Protein Blend Ingestion Following Resistance Exercise Promotes Human Muscle Protein Synthesis. J Nutr 143: 410-416, 2013.

41. Reitelseder S, Agergaard J, Doessing S, Helmark IC, Lund P, Kristensen NB, Frystyk J, Flyvbjerg A Schjerling P, van Hall G, Kjaer M, Holm L. Whey and casein labeled with L-[1-13C]leucine and muscle protein synthesis: effect of resistance exercise and protein ingestion. Am J Physiol Endocrinol Metab 300: E231-42, 2011.

42. Res PT, Groen B, Pennings B, Beelen M, Wallis GA, Gijsen AP, Senden JMG, van Loon LJC. Protein ingestion before sleep improves postexercise overnight recovery. Med Sci Sports Exerc 44: 1560-1569, 2012.

43. Robinson MM, Dasari S, Konopka AR, Johnson ML, Manjunatha S, Esponda RR, Carter RE, Lanza IR Nair KS. Enhanced Protein Translation Underlies Improved Metabolic and Physical Adaptations to Different Exercise Training Modes in Young and Old Humans. Cell Metab 25: 581-592, 2017.

44. Robinson MM, Turner SM, Hellerstein MK, Hamilton KL, Miller BF. Long-term synthesis rates of skeletal muscle DNA and protein are higher during aerobic training in older humans than in sedentary young subjects but are not altered by protein supplementation. FASEB J 25: 3240-3249, 2011.

45. Rooyackers OE, Adey DB, Ades PA, Nair KS. Effect of age on in vivo rates of mitochondrial protein synthesis in human skeletal muscle. Proc Natl Acad Sci USA 93: 15364-15369, 1996.

46. Scalzo RL, Peltonen GL, Binns SE, Shankaran M, Giordano GR, Hartley DA, Klochak AL, Lonac MC Paris HLR, Szallar SE, Wood LM, Peelor FF, Holmes WE, Hellerstein MK, Bell C, Hamilton KL, Miller BF. Greater muscle protein synthesis and mitochondrial biogenesis in males compared with females during sprint interval training. FASEB J 28: 2705-2714, 2014.

47. Schoenheimer R, Rittenberg D. Deuterium as an indicator in the study of intermediary metabolism. 1. J Bio Chem 111, 1935.

48. Schwenk WF, Tsalikian E, Beaufrere B, Haymond MW. Recycling of an amino acid label with prolonged isotope infusion: implications for kinetic studies. Am J Physiol 248: E482-7, 1985.

49. Shankaran M, King CL, Angel TE, Holmes WE, Li KW, Colangelo M, Price JC, Turner SM, Bell C Hamilton KL, Miller BF, Hellerstein MK. Circulating protein synthesis rates reveal skeletal muscle proteome dynamics. J Clin Invest 126: 288-302, 2016.

50. Tang JE, Moore DR, Kujbida GW, Tarnopolsky MA, Phillips SM. Ingestion of whey hydrolysate, casein, or soy protein isolate: effects on mixed muscle protein synthesis at rest and following resistance exercise in young men. J Appl Physiol 107: 987-992, 2009.

51. Tang JE, Perco JG, Moore DR, Wilkinson SB, Phillips SM. Resistance training alters the response of fed state mixed muscle protein synthesis in young men. Am J Physiol Regul Integr Comp Physiol 294: R1728, 2008.

52. Tipton KD, Hamilton DL, Gallagher IJ. Assessing the Role of Muscle Protein Breakdown in Response to Nutrition and Exercise in Humans. Sports Med 48: 53-64, 2018.

53. Tipton KD, Rasmussen BB, Miller SL, Wolf SE, Owens-Stovall SK, Petrini BE, Wolfe RR. Timing of amino acid-carbohydrate ingestion alters anabolic response of muscle to resistance exercise. Am J Physiol Endocrinol Metab 281: E197-206, 2001.

54. Tsalikian E, Howard C, Gerich JE, Haymond MW. Increased leucine flux in short-term fasted human subjects: evidence for increased proteolysis. Am J Physiol 247: E323-7, 1984.

55. Verdijk LB, Koopman R, Schaart G, Meijer K, Savelberg HHCM, van Loon LJC. Satellite cell content is specifically reduced in type II skeletal muscle fibers in the elderly. Am J Physiol Endocrinol Metab 292: E151-E157, 2006. 


\section{Chapter 9}

56. Wilkinson DJ, Franchi MV, Brook MS, Narici MV, Williams JP, Mitchell WK, Szewczyk NJ, Greenhaff PL, Atherton PJ, Smith K. A validation of the application of D2O stable isotope tracer techniques for monitoring day-to-day changes in muscle protein subfraction synthesis in humans. Am J Physiol Endocrinol Metab 306: E571-E579, 2014.

57. Wilkinson SB, Phillips SM, Atherton PJ, Patel R, Yarasheski KE, Tarnopolsky MA, Rennie MJ. Differential effects of resistance and endurance exercise in the fed state on signalling molecule phosphorylation and protein synthesis in human muscle. J Physiol 586: 3701-3717, 2008.

58. Wilkinson SB, Tarnopolsky MA, MacDonald MJ, Macdonald JR, Armstrong D, Phillips SM. Consumption of fluid skim milk promotes greater muscle protein accretion after resistance exercise than does consumption of an isonitrogenous and isoenergetic soy-protein beverage. Am J Clin Nutr 85: 10311040, 2007.

59. Witard OC, Jackman SR, Breen L, Smith K, Selby A, Tipton KD. Myofibrillar muscle protein synthesis rates subsequent to a meal in response to increasing doses of whey protein at rest and after resistance exercise. Am J Clin Nutr 99: 86-95, 2014.

60. Witard OC, Tieland M, Beelen M, Tipton KD, van Loon LJC, Koopman R. Resistance exercise increases postprandial muscle protein synthesis in humans. Med Sci Sports Exerc 41: 144-154, 2009.

61. Yang Y, Breen L, Burd NA, Hector AJ, Churchward-Venne TA, Josse AR, Tarnopolsky MA, Phillips SM Resistance exercise enhances myofibrillar protein synthesis with graded intakes of whey protein in older men. Br J Nutr 108: 1780-1788, 2012.

62. Yang Y, Churchward-Venne TA, Burd NA, Breen L, Tarnopolsky MA, Phillips SM. Myofibrillar protein synthesis following ingestion of soy protein isolate at rest and after resistance exercise in elderly men. Nutr Metab 9: 57, 2012. 
SUMMARY 


\section{Summary}

Age-related muscle loss, physical activity and dietary protein

Older individuals display a blunted muscle protein synthetic response to dietary protein ingestion. This anabolic resistance at least partly explains the age-related decline in skeletal muscle mass. Physical activity, and resistance-type exercise in particular, is the most potent strategy to increase muscle protein synthesis rates. Dietary protein ingestion is required to further stimulate muscle protein synthesis rates and achieve a positive net muscle protein balance during post-exercise recovery.

\section{Amount of protein}

In Chapter 2, we defined the amount of protein required to stimulate near-maximal muscle protein synthesis rates in healthy older men. Ingestion of at least $30 \mathrm{~g}$ protein results in a measurable rise in post-exercise muscle protein synthesis rates when compared to placebo ingestion. By applying intrinsically $\mathrm{L}-\left[1-{ }^{13} \mathrm{C}\right]$-phenylalanine-labeled protein, we were able to demonstrate a protein dose-dependent increase in the incorporation of $\mathrm{L}-\left[1-{ }^{13} \mathrm{C}\right]-$ phenylalanine into myofibrillar protein, with ingestion of $45 \mathrm{~g}$ protein providing a greater amount of dietary protein-derived phenylalanine for de novo muscle protein synthesis. This finding demonstrates that whereas muscle protein synthesis rates were stimulated after ingestion of 30-45 g protein, ingestion of greater protein doses provide greater amounts of amino acid precursors that are utilized to support the increase in de novo muscle protein synthesis rates.

\section{Leucine co-ingestion}

Ingesting 30-45 g protein in a single mixed meal may be practically challenging for certain older populations. The amino acid leucine has been established as one of the most anabolic amino acids due to its ability to phosphorylate key anabolic signaling proteins (i.e., mTORC1 and S6K) in skeletal muscle tissue. Therefore, in Chapter 3, we assessed post-prandial protein handling and the muscle protein synthetic response to the ingestion of a smaller, 15 $\mathrm{g}$ protein dose with or without additional free leucine $(1.5 \mathrm{~g})$ during recovery from resistancetype exercise in older individuals. Interestingly, free leucine co-ingestion seemed to compromise protein digestion and/or amino acid absorption as dietary protein-derived phenylalanine availability was lower over the entire $6 \mathrm{~h}$ post-prandial period compared with ingestion of only $15 \mathrm{~g}$ protein. Nevertheless, we demonstrate that free leucine co-ingestion with $15 \mathrm{~g}$ protein stimulates greater muscle protein synthesis rates compared with ingestion of only $15 \mathrm{~g}$ protein. 


\section{Pre-sleep dietary protein ingestion}

Besides augmenting the muscle protein synthetic response to a post-exercise meal, optimal timing of meal ingestion may also aid in compensating for anabolic resistance in older individuals. In Chapter 4, we assessed whether a bout of resistance-type exercise could augment the overnight muscle protein synthetic response dietary protein ingested prior to sleep in older men. We observed that approximately $55 \%$ of the ingested dietary protein became available in the circulation during sleep. Furthermore, the prior bout of exercise substantially increased overnight muscle protein rates, with $28 \%$ more dietary proteinderived amino acids being directed toward de novo overnight muscle protein synthesis.

The ingestion of more rapidly digestible protein sources results in a greater post-prandial rise in circulating amino acid concentrations, which thereby further increases muscle protein synthesis rates. We speculated that protein digestion and absorption might also be modulated by an external factor as simple as body position (i.e., sitting upright or lying down). In Chapter 5, we tested the impact of protein ingestion in an upright position compared with a head-down tilted $\left(-20^{\circ}\right)$ supine body position. As expected, peak leucine concentration and plasma amino acid availability were lower after protein ingestion in the inverted position when compared with the upright seated position. These proof-of-principle findings may not necessarily carry over to real-life situations. Therefore, in Chapter 6, we tested the impact of protein ingestion in a horizontal, supine body position compared with an upright seated position. We found that gastric emptying was accelerated and the rise in circulating leucine concentration was greater in the upright seated position compared with the horizontal supine position. These findings indicate that body position modulates rate of dietary protein digestion and absorption and impacts amino acid availability in the circulation, which may impact post-prandial muscle protein synthesis rates.

\section{Long-term assessment of muscle protein synthesis rates}

Recently, the application of deuterated water $\left({ }^{2} \mathrm{H}_{2} \mathrm{O}\right)$ has re-emerged in the field as an approach to assess muscle protein synthesis rates over multiple days or weeks in vivo in humans. We applied oral deuterated water dosing in Chapter 7 to assess the impact of resistance-type exercise training on local muscle protein synthesis rates over a three-day period in healthy, younger males. We found that that daily resistance-type exercise stimulated muscle protein synthesis rates over multiple days. Whereas acute labeled amino acid infusion studies have shown that resistance-type exercise increases muscle protein synthesis rates by 50-100\%, we observed a lower impact of resistance-type exercise on the muscle protein synthetic response $(\sim 25 \%)$ under free-living conditions. This discrepancy between tracer methodologies likely reflects the impact of other anabolic factors, such as dietary protein intake, habitual physical activity, sleep and hormonal fluctuations, which are incorporated into the more prolonged assessment of muscle protein synthesis rates. 


\section{Prolonged resistance-type exercise training}

In Chapter 8, we hypothesized that supplementation with leucine-enriched whey protein provided immediately after training and every night prior to sleep would further augment the muscle protein synthetic response during post-exercise recovery and therefore lead to greater gains in muscle mass and strength following more prolonged training in active older men. While twelve weeks of resistance-type exercise training increased whole body lean mass and maximal leg extension strength, protein supplementation did not further increase muscle mass or strength gains over the 12-week training intervention. These findings demonstrate that protein supplementation may not provide added benefit to muscle mass and strength gains following resistance-type exercise training in healthy, active older individuals who already consume ample amounts of protein.

In order to assess the muscle anabolic response to protein supplementation during training, we provided subjects with deuterated water $\left({ }^{2} \mathrm{H}_{2} \mathrm{O}\right)$ throughout week 12 of the training intervention and collected additional muscle biopsy samples. In line with our findings on differences in muscle mass and strength, we observed no difference in myofibrillar protein synthesis rates between the placebo- and protein-supplemented groups.

\section{Future application of deuterated water methods to study muscle protein metabolism}

In the final chapter of this dissertation, we discuss novel methodology based around deuterated water administration to study human muscle protein metabolism. In particular, application of deuterated water methods within long-term intervention studies may provide us with a better understanding of the dynamic regulation of muscle protein synthesis underlying skeletal muscle hypertrophy and atrophy. Deuterated water ingestion combined with recent developments in high-throughput analytical techniques allows for simultaneous in vivo assessment of the fractional synthesis rates of hundreds of individual proteins. This proteome dynamics approach represents an important methodological development in the field of human muscle protein metabolism and future application will provide more complete insight into the dynamic regulation of skeletal muscle protein reconditioning. 
VALORIZATION 
The age-related loss of skeletal muscle mass and strength, termed sarcopenia, increases the risk of disease development, hospitalization, and loss of independence in our older population. It is expected that the population over 65 years of age will triple in the upcoming 40 years. Together, the prevalence of sarcopenia and expansion in our older population will overburden existing health care systems. In order to maintain good health in our older population and offset the associated increase in health care costs, we must develop and apply strategies targeted at counteracting the progression of sarcopenia.

Older individuals display a blunted muscle protein synthetic response to protein ingestion, termed anabolic resistance, which is a major factor contributing to the loss of skeletal muscle mass. It is therefore evident that effective strategies should be targeted at compensating for the presence of anabolic resistance in our older population. In the present dissertation, we provide further evidence in older men that a bout of resistance-type exercise potently increases muscle protein synthesis rates (Chapters 4 and 7) and that prolonged resistancetype exercise training substantially increases skeletal muscle mass and strength (Chapter 8 ). As such, it is clear that participation in a resistance-type exercise training program should form the basis for nearly all strategies aimed at preserving skeletal muscle mass and strength in the older population.

Protein ingestion following exercise further increases muscle protein synthesis rates during post-exercise recovery. The amount of protein ingested following exercise is arguably the key nutritional factor dictating the magnitude of the increase in post-exercise muscle protein synthesis rates. However, the amount of ingested protein required to stimulate near-maximal post-exercise muscle protein synthesis rates has not yet been fully defined for the older population. Within the present dissertation (Chapter 2), it was demonstrated that older individuals require the ingestion of meals containing $30-45 \mathrm{~g}$ of protein is required to stimulate a near-maximal muscle protein synthetic response during post-exercise recovery. Considering that most people ingest 3 meals per day, the ingestion of meals containing 30 $45 \mathrm{~g}$ protein would result in a daily protein intake of $90-135 \mathrm{~g} \cdot \mathrm{d}^{-1}$, or $1.2-1.8 \mathrm{~g} \cdot \mathrm{kg}^{-1} \cdot \mathrm{d}^{-1}$ in a 75 $\mathrm{kg}$ older person. Recent dietary intake data has revealed that habitual protein intake is 1.0$1.2 \mathrm{~g} \cdot \mathrm{kg}^{-1} \cdot \mathrm{d}^{-1}$ in healthy, older individuals and 0-8-0.9 $\mathrm{g} \cdot \mathrm{kg}^{-1} \cdot \mathrm{d}^{-1}$ in frail, older individuals (4). It is therefore apparent that increasing protein intake in older individuals may be practically challenging. However, there are a number of possible solutions that have been described to increase protein intake in various older populations. Aside from simply ingesting more food, older individuals could increase protein intake by co-ingesting isolated protein sources (e.g., protein shakes) with the main meals. Alternatively, protein-enriched food products appear to be an effective strategy to increase protein intake in various older populations $(1,2)$. Ingestion of isolated protein shakes and/or protein-enriched food products would be most effective if ingested with meals that do not typically contain more than $30 \mathrm{~g}$ protein, such as breakfast and lunch (4). Dietary intake data has also revealed that older individuals do not ingest protein in the evening (4). It has therefore been proposed that protein ingestion prior to sleep may represent an opportunity to increase dietary protein intake in the older 
population. We report in the present thesis (Chapter 4) that pre-sleep protein ingestion is properly digested and absorbed and, when combined with physical activity, robustly increases overnight muscle protein synthesis rates. These data provide further support that pre-sleep protein ingestion may represent an effective nutritional strategy to compensate for anabolic resistance.

Aside from strategies aimed at increasing dietary protein intake, co-ingestion of certain single nutrients appears to augment muscle protein synthesis rates when smaller protein doses are ingested (5). In Chapter 3 of the present thesis, we demonstrate that free leucine co-ingestion with $15 \mathrm{~g}$ protein stimulates greater muscle protein synthesis rates compared with ingestion of only $15 \mathrm{~g}$ protein during post-exercise recovery in the older population. As such, older individuals may also compensate for insufficient dietary protein intake by coingesting each meal with a small amount of free leucine. This may be of particular relevance in certain older populations that struggle to consume adequate amounts of protein intake. Development of products containing free leucine (e.g., dissolvable powders, beverages, desserts, pills, gum, gels) represents a practical approach for implementation of free leucine co-ingestion in the general population. Alternatively, future product development should explore the efficacy of fortifying food products with free leucine to augment the anabolic response to meal ingestion.

Older individuals are far more likely to be admitted to the hospital when compared to the younger population. Short-term hospital stays necessitate bed rest, which can dramatically accelerate the progression of age-related skeletal muscle mass and strength loss (3). While in bed, hospitalized patients spend most of the time lying in a supine body position. It is known that the digestibility of protein sources can modulate the post-prandial rise in circulating amino acid concentrations, which thereby impacts post-prandial muscle protein synthesis rates (6). We demonstrated in the present thesis (Chapters 5 and 6) that protein digestion and absorption is impacted by body position. In particular, we found that peak leucine concentration and plasma amino acid availability was greater when protein was ingested in an upright, seated position when compared with a supine, lying position. It is proposed that consuming food in an upright body position may promote a greater increase in post-prandial muscle protein synthesis rates. Current clinical nutrition protocols do not typically incorporate guidelines regarding the body position of patients during feeding. Based on early findings, however, future research should investigate the impact of body position on post prandial muscle protein synthesis rates in more clinically compromised populations. Knowledge on this topic could be used to innovate currently existing clinical nutrition guidelines to accelerate recovery and attenuate the age-related loss in skeletal muscle mass and strength in a variety of populations. Such innovation may be as simple as providing hospital patients with a communal dining space to encourage patients to sit (upright) while eating meals.

Even though the benefits of resistance-type exercise training and dietary protein intake on skeletal muscle mass and strength may be widely known, they are not yet considered by the 
general public to be relevant for older individuals. With this in mind, we must first implement strategies to educate older people to recognize the importance of maintaining skeletal muscle mass and strength. Along with improving awareness, we also need to provide our older population with an environment to better facilitate participation in exercise training. This knowledge translation to the general public and facilitation of exercise participation will likely be most effective if carried out through large-scale collaboration. For example, scientists are required to generate data to demonstrate the health implications of skeletal muscle loss and better understand the efficacy of novel exercise and dietary interventions to counteract skeletal muscle loss. Medical and scientific societies are required to incorporate relevant scientific findings into current public guidelines for healthy lifestyle. Considering the proposed financial burden of age-related muscle loss on existing healthcare systems, implementation of national-level exercise programs would offset the projected increase in age-related health care costs. Therefore, governmental intervention is required to develop and introduce new policies and fund programs aimed at educating and implementing strategies to increase muscle mass and strength in the older population. Additional financial support may be attained by insurance companies as older individuals in good health would presumably continue contributing to insurance policies as opposed to drawing insurance claims. Funding should be targeted to support construction of new facilities that are readily available to the general public and possess the capacity to support the coming expansion in the older population. Current nutritional information, some of which has been described in the present thesis, and advice should be provided at fitness facilities to maximize the health benefits of exercise training. Provision of this information should occur though professional health practitioners, which include: kinesiologists and registered dietitians, as well as physicians, nurses, and personal care-givers.

\section{Personal perspective}

It is clear that we must develop a deeper understanding of skeletal muscle tissue deconditioning that occurs over the lifespan. With this knowledge, we can better design intervention strategies to counteract skeletal muscle mass loss and the associated negative health consequences. While we have developed an understanding of age-related skeletal muscle mass loss on a whole-body level, the impact of aging on the regulation of skeletal muscle protein reconditioning still remains unclear. As discussed in Chapter 9, the application of deuterated water (Chapters 7 and 8) improves isotopic label detection in peptides, allowing simultaneous assessment of in vivo synthesis rates of several individual skeletal muscle proteins. This technique has been termed dynamic proteomics. Individual skeletal muscle protein regulation determines whole-body metabolic and functional consequences. Therefore, application of the dynamic proteomics method in older individuals will allow for the determination of dysregulated individual protein translation that is associated with aging. Subsequent investigation into the impact of various exercise and 
nutritional intervention strategies will provide us with a better understanding of how such strategies counteract the dysregulation and contribute to improvements in metabolic health and physical function. Further exploration will allow us to optimize intervention strategies so that we can more effectively counteract the progression of sarcopenia. Investigation into the impact of aging and short-term muscular disuse on individual protein synthesis rates will be the focus of my post-doctoral work. 


\section{References}

1. Beelen J, de Roos NM, de Groot LCPGM. A 12-week intervention with protein-enriched foods and drinks improved protein intake but not physical performance of older patients during the first 6 months after hospital release: a randomised controlled trial. Br J Nutr 117: 1541-1549, 2017.

2. Beelen J, Vasse E, Janssen N, Janse A, de Roos NM, de Groot LCPGM. Protein-enriched familiar foods and drinks improve protein intake of hospitalized older patients: A randomized controlled trial. Clin Nutr 37: 1186-1192, 2018.

3. Dirks ML, Wall BT, van de Valk B, Holloway TM, Holloway GP, Chabowski A, Goossens GH, van Loon LJC. One week of bed rest leads to substantial muscle atrophy and induces whole-body insulin resistance in the absence of skeletal muscle lipid accumulation. Diabetes (June 29, 2016). doi: 10.2337/db15-1661.

4. Tieland M, Borgonjen-Van den Berg KJ, van Loon LJC, de Groot LCPGM. Dietary protein intake in community-dwelling, frail, and institutionalized elderly people: scope for improvement. Eur J Nutr 51: 173179, 2012.

5. van Vliet S, Beals J, Martinez I, Skinner S, Burd N. Achieving Optimal Post-Exercise Muscle Protein Remodeling in Physically Active Adults through Whole Food Consumption. Nutrients 10: 224-14, 2018.

6. West DW, Burd NA, Coffey VG, Baker SK, Burke LM, Hawley JA, Moore DR, Stellingwerff T, Phillips SM. Rapid aminoacidemia enhances myofibrillar protein synthesis and anabolic intramuscular signaling responses after resistance exercise. Am J Clin Nutr 94: 795-803, 2011. 


\section{ACKNOWLEDGEMENTS}


The completion of this thesis has taken a lot of dedication and hard work. There are many people that helped push along the way.

Luc, thank you for the opportunity to come to Maastricht and for your support and mentorship over these last years. Your determined approach to research and your scientific integrity is something I will carry throughout my career. I appreciate our many discussions and look forward to developing more ideas at the Frape (and eventually performing the study).

Nick, thank you for been one of my closest mentors and for the continued helpful input and guidance. We have some great memories from our time together at McMaster and Maastricht, and from recent times at conferences. These days, I can always count on a good laugh during a quick chat online. Thanks for being a great mentor and friend.

To my former supervisors, Stu and Marius, thank you for providing me with my first opportunities to get involved in exercise physiology, muscle and nutrition research. Your trust in me early on set me on my path to pursue a career in research. My time spent under your supervision sparked and encouraged my curiosity and drive, which I will continue to hold throughout my career.

Thanks to the Canadians who lived in Maastricht throughout my $\mathrm{PhD}$ period and made it a bit more like home. Alana, thanks for the help with settling in (and reminders about my veggie intake) during my first few months in Maastricht. Tyler, thanks for the many helpful discussions and continued friendship. Graham and Tanya, it was great getting to know you and the boys during your time in Maastricht. Thank you for the continued friendship, guidance and support.

Thank you to all of my current and past colleagues for the day-to-day support over the years. Tim, Stefan, Jan-Willem, Lisanne, Cindy, Kristin, Michelle, Milou, Philippe, Milan, Kenneth, Rachel, Floris, Gabriel, Wesley, Ben, Marlou, Fleur, and Bart. I couldn't have asked to work alongside a more motivated and hard-working group of people. Jorn and Imre, the overnight team, thanks for the good memories from the many test nights during my first year in Maastricht. Cas, Jorn, Kevin, Maarten and Jean, thanks for the friendship over the years, for the many jokes and fun during the dinners at B3 headquarters, and for all the support in the lab. Thank you to the $4 \mathrm{Js}$ : Joey, Janneau, Joy, and Joan as well as Antoine, Freek, Loek, Wendy, Hasibe, and Annemie. The studies in this thesis would not have been possible without your expertise and hard work. Thanks for your dedication, helpful input, analytical expertise, and most importantly the many laughs. Lex, thanks for the guidance and valuable input and for the many helpful discussions over the last few years. Cleo, thank you for providing solid day-to-day support as well as all the help when I was preparing to move over 
to Maastricht. Desiree, thank you for making a welcoming and fun atmosphere every day at the department. To the one-of-a-kind Jos, thank you for the friendship and for the fun times at the Friday afternoon Borrels. Your presence at the department is missed every day! In your words: Bedankt, punt!

Thank you to Prof. dr. Mariman, Prof. dr. Olde Damink, Prof. dr. Saris, Prof. dr. Rooyakers, Prof. dr. Burniston for taking the time to carefully evaluate this thesis.

To Ben and Karyn and the research group at Colorado St. University, thank you for being such welcoming and supportive hosts. It was great to experience how your lab combines a variety of research models and your different applications of deuterated water.

Stefan and Sandra, thank you for the great friendship over the last few years. I have a lot of great memories from nights out in the city.

Thank you to my best friends back home: Jeremy, Steve, AJ, Shawn, Cody, Lana, Jen, and Steph. I'm extremely lucky to have a strong group of supportive, interesting and motivating friends. Thank you for keeping me close over the last few years.

Ook Piet, Toos, Rik, Annemiek, Stijn en Raf (en ook de rest van de families Backx en Poncin), bedankt voor jullie warme welkom, interesse en steun.

Uncle Dave and Aunt Marie, thank you for the love and support over the years. I have great memories from travelling together with you to Marbella, Ghent and Maastricht during the first year of my PhD. Thank you for encouraging me to explore. Marie, I miss you every day.

Katie, you are a tremendous source of inspiration and a great role-model. Thank you for the countless jokes and laughs, for your love and support, and for always being available for a good chat.

Mom and Dad, the completion of this thesis would not have been possible without your love and encouragement. While it is certainly not always easy living so far away from home, I am grateful to have your support in everything I do.

Evelien, your support has been essential over the last few years. You are always willing to listen and provide valuable input on everything, even for the not-so-exciting stuff that would put most people to sleep. Thank you for your close friendship and for all your love and support over the years. 

CURRICULUM VITAE 


\section{Curriculum Vitae}

Andrew Holwerda was born on May 12, 1987 in Hamilton, Ontario, Canada. He completed secondary school at Saltfleet Highschool in Stoney Creek in 2006. Andrew obtained his Honours Bachelors degree in Kinesiology from McMaster University in Canada in 2010. During this time, Andrew began performing muscle protein metabolism research under the supervision of Dr. Stuart Phillips. He was a co-investigator on studies assessing the impact of skeletal muscle contraction intensity and volume as well as post-exercise hormonal responses on post-exercise muscle protein synthesis rates and skeletal muscle adaptation to resistance exercise training. He was also awarded with an entrance scholarship from McMaster University, a conference travel bursary from the Faculty of Science and a Canadian Institutes of Health Research (CIHR) Undergraduate Research Fellowship. Andrew then completed a Masters degree in the Faculty of Kinesiology and Physical Education at the University of Toronto under the supervision of Dr. Marius Locke. Andrew's Masters dissertation investigated the impact of lengthening and shortening skeletal muscle contractions on the skeletal muscle damage response. Andrew was awarded with a Graduate Student Fellowship from the Faculty of Kinesiology and Physical Education. After finishing his Masters degree, Andrew moved abroad to Maastricht University to complete PhD training under the supervision of Prof. Dr. Luc van Loon. During his PhD, Andrew applied stable isotope methodologies to study the impact of exercise and nutrition on the muscle protein adaptive response to exercise in the older population. Andrew helped produce intrinsically-labeled milk protein, which was applied for the study of protein digestion and absorption and whole-body protein metabolism. Andrew also applied deuterium oxide $\left({ }^{2} \mathrm{H}_{2} \mathrm{O}\right)$ for the assessment of muscle protein synthesis rates over multiple days in humans. Andrew was awarded with an International Student Award and Gail E. Butterfield Award from the American College of Sports Medicine (ACSM), two Gatorade Sports Science Nutrition Awards at the European Congress of Sports Science (ECSS) and a Kootstra Talented Researcher Fellowship from the Faculty of Health, Medicine and Life Sciences at Maastricht University. Andrew is currently a post-doctoral research fellow at Maastricht University. 


\section{List of publications}

Snijders T, Trommelen J, Kouw IWK, Holwerda AM, Verdijk LB, van Loon LJC. The impact of pre-sleep protein ingestion on the skeletal muscle adaptive response to exercise in humans: an update. Front Nutr In Press, 2019.

Dirks ML, Smeets JSJ, Holwerda AM, Kouw IWK, Marzuca-Nassr GN, Gijsen AP, Holloway GP, Verdijk LB, van Loon LJC. Dietary feeding pattern does not modulate the loss of muscle mass or the decline in metabolic health during short-term bed rest. Am J Physiol Endocrinol Metab 102: 828, 2019.

Holwerda AM, Paulussen KJM, Overkamp M,Goessens JPB, Kramer IF, Wodzig WKWH, Verdijk LB, van Loon LJC. Dose-Dependent Increases in Whole-Body Net Protein Balance and Dietary Protein-Derived Amino Acid Incorporation into Myofibrillar Protein During Recovery from Resistance Exercise in Older Men. J Nutr In Press, 2018.

Holwerda AM, Overkamp M, Paulussen KJM, Smeets JSJ, van Kranenburg J, Backx EMP, Gijsen AP, Goessens JPB, Verdijk LB, van Loon LJC. Protein Supplementation after Exercise and before Sleep Does Not Further Augment Muscle Mass and Strength Gains during Resistance Exercise Training in Active Older Men. J Nutr 148: 1723-1732, 2018.

Holloway GP, Holwerda AM, Miotto PM, Dirks ML, Verdijk LB, van Loon LJC. AgeAssociated Impairments in Mitochondrial ADP Sensitivity Contribute to Redox Stress in Senescent Human Skeletal Muscle. Cell Rep. 22: 2837-2848, 2018.

Niemeijer VM, Snijders T, Verdijk LB, van Kranenburg J, Groen BBL, Holwerda AM, Spee RF, Wijn PFF, van Loon LJC, Kemps HMC. Skeletal muscle fiber characteristics in patients with chronic heart failure: impact of disease severity and relation with muscle oxygenation during exercise. J Appl Physiol 125: 1266-1276, 2018.

Trommelen J, Kouw IWK, Holwerda AM, Snijders T, Halson SL, Rollo I, Verdijk LB, van Loon LJC. Presleep dietary protein-derived amino acids are incorporated in myofibrillar protein during postexercise overnight recovery. Am J Physiol Endocrinol Metab 314: E457-E467, 2018.

Holwerda AM, Paulussen KJM, Overkamp M, Smeets JSJ, Gijsen AP, Goessens JPB, Verdijk LB, van Loon LJC. Daily resistance-type exercise stimulates muscle protein synthesis in vivo in young men. J Appl Physiol 124: 66-75, 2018.

Kouw IW, Holwerda AM, Trommelen J, Kramer IF, Bastiaanse J, Halson SL, Wodzig WK, Verdijk LB, van Loon LJ. Protein Ingestion before Sleep Increases Overnight Muscle Protein Synthesis Rates in Healthy Older Men: A Randomized Controlled Trial. J Nutr 147: 22522261, 2017.

Holwerda AM, Lenaerts K, Bierau J, Wodzig WKWH, van Loon LJC. Food ingestion in an upright sitting position increases postprandial amino acid availability when compared with food ingestion in a lying down position. Appl Physiol Nutr Metab 42: 738-743, 2017. 
Trommelen J, Holwerda AM, Kouw IWK, Langer H, Halson SL, Rollo I, Verdijk LB, van Loon LJC. Resistance Exercise Augments Postprandial Overnight Muscle Protein Synthesis Rates. Med Sci Sports Exerc 48: 2517-2525, 2016.

Holwerda AM, Kouw IWK, Trommelen J, Halson SL, Wodzig WK, Verdijk LB, van Loon LJ. Physical Activity Performed in the Evening Increases the Overnight Muscle Protein Synthetic Response to Presleep Protein Ingestion in Older Men. J Nutr 146: 1307-1314, 2016.

Holwerda AM, Lenaerts K, Bierau J, van Loon LJC. Body Position Modulates Gastric Emptying and Affects the Post-Prandial Rise in Plasma Amino Acid Concentrations Following Protein Ingestion in Humans. Nutrients 8, 2016.

Churchward-Venne TA, Holwerda AM, Phillips SM, van Loon LJC. What is the Optimal Amount of Protein to Support Post-Exercise Skeletal Muscle Reconditioning in the Older Adult? Sports Med 46: 1205-1212, 2016.

Holwerda AM, Locke M. Hsp25 and Hsp72 content in rat skeletal muscle following controlled shortening and lengthening contractions. Appl Physiol Nutr Metab 39: 1380 1387, 2014.

Holwerda AM, van Vliet S, Trommelen J. Refining dietary protein recommendations for the athlete. J Physiol 591: 2967-2968, 2013.

Burd NA, Holwerda AM, Selby KC, West DWD, Staples AW, Cain NE, Cashaback JGA, Potvin JR, Baker SK, Phillips SM. Resistance exercise volume affects myofibrillar protein synthesis and anabolic signalling molecule phosphorylation in young men. J Physiol 588: 3119-3130, 2010.

Burd NA, West DWD, Staples AW, Atherton PJ, Baker JM, Moore DR, Holwerda AM, Parise G, Rennie MJ, Baker SK, Phillips SM. Low-Load High Volume Resistance Exercise Stimulates Muscle Protein Synthesis More Than High-Load Low Volume Resistance Exercise in Young Men. PLoS ONE 5: e12033-10, 2010.

Josse AR, Sherriffs SS, Holwerda AM, Andrews R, Staples AW, Phillips SM. Effects of capsinoid ingestion on energy expenditure and lipid oxidation at rest and during exercise. Nutr Metab 7: 65-10, 2010.

West DWD, Burd NA, Tang JE, Moore DR, Staples AW, Holwerda AM, Baker SK, Phillips SM. Elevations in ostensibly anabolic hormones with resistance exercise enhance neither training-induced muscle hypertrophy nor strength of the elbow flexors. J Appl Physiol 108: 60-67, 2010. 


\section{Oral Presentations}

Holwerda AM, Overkamp M, Paulussen KJM, Smeets JSJ, Gijsen AP, Goessens JPB, Verdijk LB, van Loon LJC. Leucine-Enriched Protein Supplementation Does Not Augment Muscle Mass and Strength Gains During Resistance-Type Exercise Training in Older Males. European College of Sport Science (ECSS) Annual Congress, July 2018, Dublin, Ireland.

Holwerda AM. The use of labeled water to assess muscle protein synthesis rates. ESPEN intensive course in tracer methodology in metabolism, June 2018, Maastricht University.

Holwerda AM. Deuterium oxide for the measurement of muscle protein synthesis in humans. Masterclass: The use of stable isotopes in clinical research, Sept 2017, Maastricht University.

Holwerda AM. Exercise and dietary protein to support healthy aging. Dept. of Health and Exercise Science, Colorado State University, August 2017, Fort Collins, USA.

Holwerda AM, Paulussen KJM, Overkamp M, Goessens JPB, Kramer AF, Wodzig WKWH, Verdijk LB and van Loon LJC. Post-prandial protein handling following ingestion of different amounts of protein during post-exercise recovery in older males. European College of Sport Science (ECSS) Annual Congress, July 2017, Metropolis-Ruhr, Germany.

Holwerda AM. Latest research insights into protein timing - window of opportunity in the evening. Bridge2Food: $7^{\text {th }}$ Sports \& Performance Nutrition Summit, June 2017, Amsterdam, The Netherlands.

Holwerda AM, Paulussen KJM, Overkamp M, Goessens JPB, Kramer AF, Wodzig WKWH, Verdijk LB and van Loon LJC. Post-prandial protein handling following ingestion of different amounts of protein during post-exercise recovery in older males. Benelux Association of Stable Isotope Scientists (BASIS) Annual Meeting, May 2017, Utrecht, The Netherlands.

Holwerda AM, Paulussen KJM, Overkamp M, Goessens JPB, Kramer AF, Wodzig WKWH, Verdijk LB and van Loon LJC. Post-prandial protein handling following ingestion of different amounts of protein during post-exercise recovery in older males. Experimental Biology Annual Meeting, April 2017, Chicago, U.S.A.

Holwerda AM, Kouw IW, Trommelen J, Halson SL, Wodzig WKWH, Verdijk LB, van Loon LJ. Exercise enhances the overnight muscle protein synthetic response to pre-sleep protein feeding in older males. European College of Sport Science (ECSS) Annual Congress, July 2016, Vienna, Austria.

Holwerda AM. Building Muscle. Innovative research focus for health science students. May 2016, Maastricht University.

Holwerda AM, Locke M. Heat shock protein expression in skeletal muscle after lengthening 


\section{Curriculum Vitae}

or shortening contractions. Canadian Society of Exercise Physiology Annual Meeting, November 2013, Toronto, Canada.

Holwerda AM, Burd NA, Selby KC, West DWD, Staples AW, Cain NE, Cashaback J, Potvin JR, Baker SK, Phillips SM. Three sets of resistance exercise elicits a greater elevation in myofibrillar protein synthesis than one set of resistance exercise in young men. Canadian Society of Exercise Physiology Annual Meeting, November 2010, Toronto, Canada.

Holwerda AM, Burd NA, Selby KC, Staples AW, Cain N, Andrews RJ, Phillips SM. Multiple sets of resistance exercise induce greater increases in myofibrillar protein synthesis than a single set of resistance exercise. Ontario Exercise Physiology Conference, January 2010, Barrie, Canada. 


\section{Poster Presentations}

Holwerda AM, Overkamp M, Paulussen KJM, Smeets JSJ, Gijsen AP, Goessens JPB, Verdijk LB, van Loon LJC. Leucine-Enriched Protein Supplementation Does Not Augment Muscle Mass and Strength Gains During Resistance-Type Exercise Training in Older Males. Thematic Poster. American College of Sports Medicine Annual Meeting, May 2018, Minneapolis, USA.

Holwerda AM, Paulussen KJM, Overkamp M, Goessens JPB, Kramer AF, Wodzig WKWH, Verdijk LB and van Loon LJC. Post-prandial protein handling following ingestion of different amounts of protein during post-exercise recovery in older males. Dutch Society for Research on Ageing (DuSRA) Annual Meeting, May 2017, Leiden, the Netherlands.

Holwerda AM, Gijsen AP, Goessens JPB, Senden JMG, de Boer D, Wodzig WKWH, van Loon LJC. Deuterium oxide $\left({ }^{2} \mathrm{H}_{2} \mathrm{O}\right)$ dosing to measure muscle protein synthesis rates in vivo in humans. Thematic Poster. Joint European Stable Isotopes User group Meeting (JESIUM), Sept 2016, Ghent, Belgium.

Holwerda AM, Kouw IW, Trommelen J, Halson SL, Wodzig WKWH, Verdijk LB, van Loon LJ. Physical activity performed in the evening increases the overnight muscle protein synthetic response to pre-sleep protein feeding in older men. Thematic Poster. American College of Sports Medicine Annual Meeting, May 2016, Boston, USA.

Holwerda AM, Lenaerts K, Bierau J, van Loon LJC. Gastric emptying is delayed when protein is ingested in a supine compared with a sitting position. NUTRIM Symposium December 2015, Maastricht University, Maastricht, The Netherlands. 
Curriculum Vitae

Research Fellowships

2017 Kootstra Talented Researcher Fellowship,

Faculty of Health, Medicine and Life Sciences (FHML)

Maastricht University

2011 Graduate Student Fellowship,

University of Toronto

$2008 \quad$ Undergraduate Student Research Fellowship,

Canadian Institutes of Health Research (CIHR)

Academic Awards and Prizes

2018 Gail E. Butterfield Nutrition Travel Award, American College of Sport Medicine (ACSM)

2017

$2^{\text {nd }}$ Place GSSI Nutrition Award,

European Congress of Sport Science (ECSS)

2017 BASIS Fund, Travel Award,

Benelux Association of Stable Isotope Scientists (BASIS)

2016

$1^{\text {st }}$ Place Oral Presentation Competition,

Dutch Society for Human Movement Sciences (VvBN)

2016 Finalist GSSI Nutrition Award,

European Congress of Sport Science (ECSS)

2016 International Student Award,

American College of Sport Medicine (ACSM)

2009 Undergraduate Research Travel Award,

McMaster University

2008 McMaster Marauder Scholar, Student-Athlete Achievement, McMaster University

2006 McMaster University Honour Award, Entrance Scholarship, McMaster University 
FINANCIAL SUPPORT 
Financial support for the printing of this thesis was kindly provided by
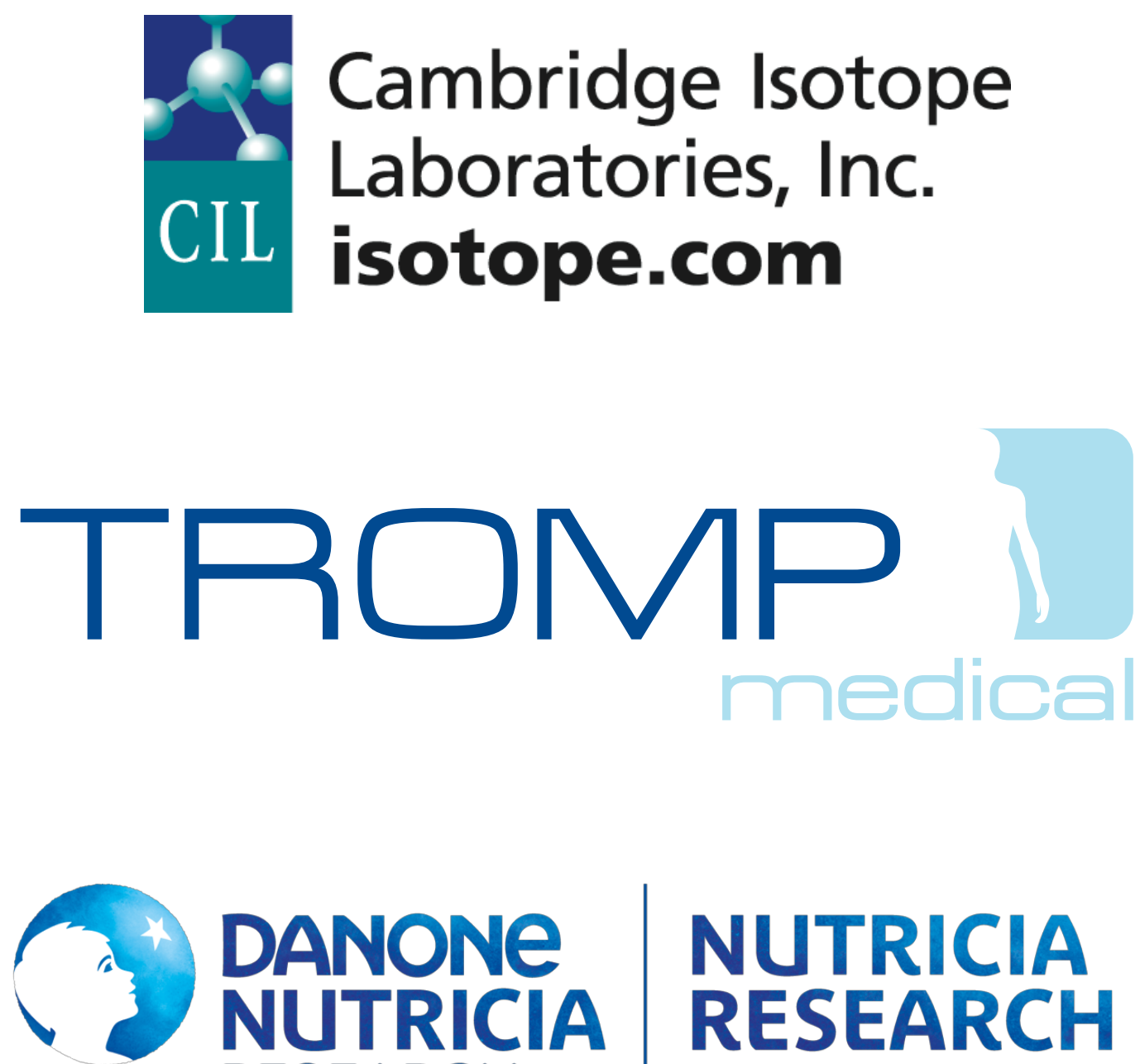

DANONE NUTRICIA

NUTRICIA RESEARCH

RESEARCH 
